\title{
Барбара Оляшек
}

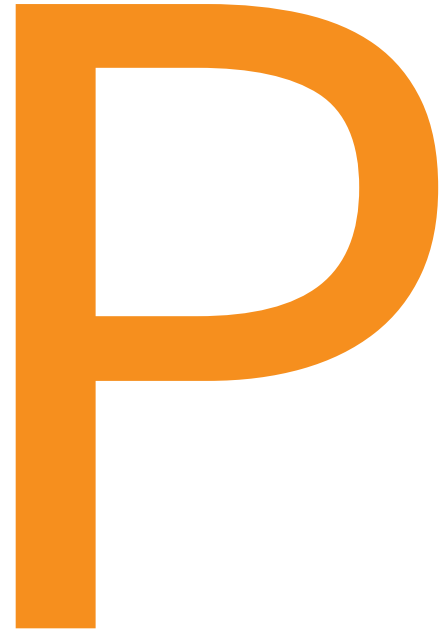

\section{«Русские споры» в художественном дискурсе классиков}

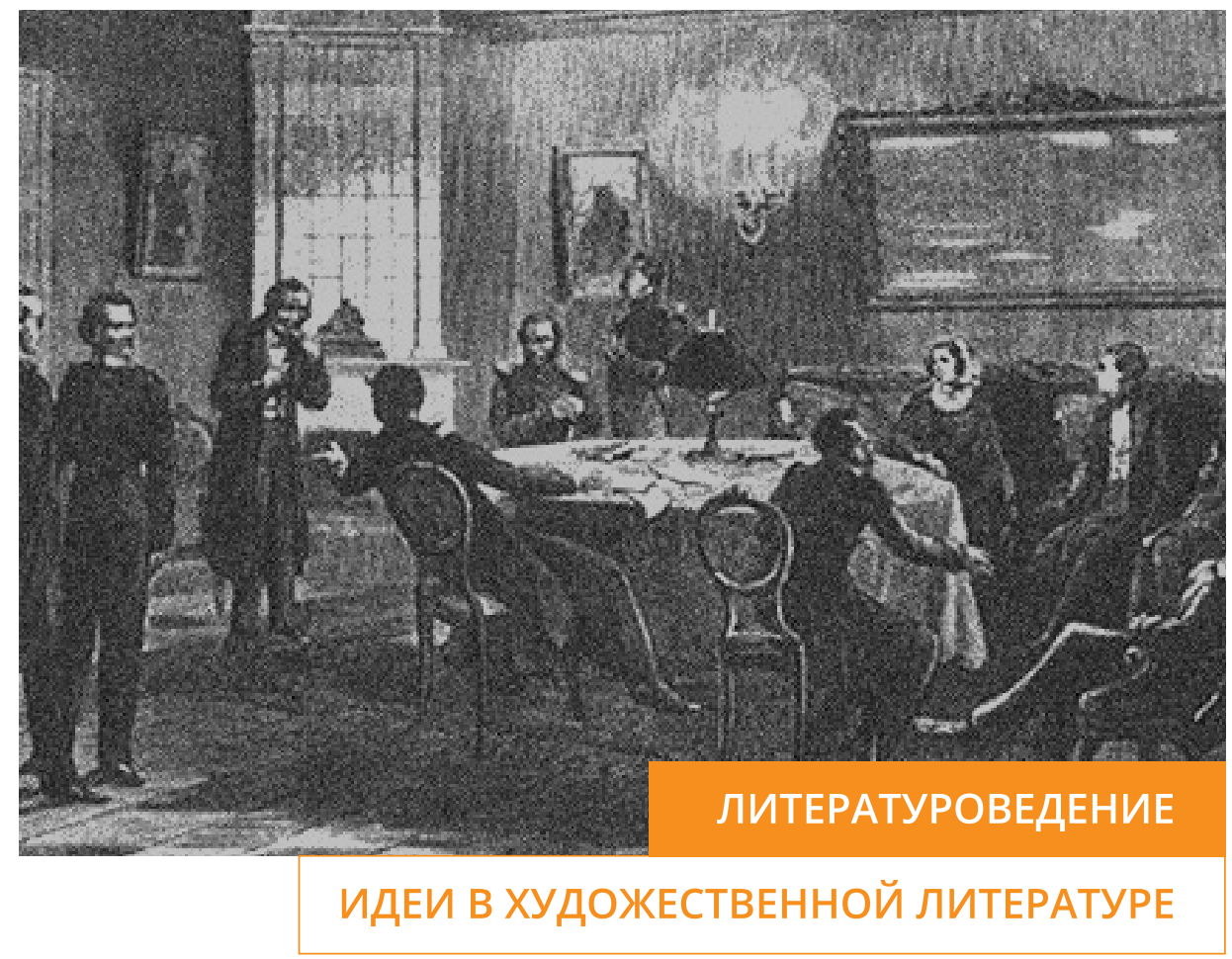


«Русские споры»

в художественном

дискурсе классиков 
造 
Барбара Оляшек

\section{«Русские споры» в художественном дискурсе классиков}


Barbara Olaszek - Лодзинский университет, Филологический факультет

Кафедра русской литературы и культуры, 90-236 Лодзь, ул. Поморска 171/173

РЕЦЕНЗЕНТ

Василий Щукин

РЕДАКТОР

Urszula Dzieciątkowska

НАБОР И ВЁРСТКА ТЕКСТА

Munda - Maciej Torz

ТЕХНИЧЕСКИЙ РЕДАКТОР

Leonora Wojciechowska

ПРОЕКТ ОБЛОЖКИ

Studio $7 A$

В оформлении обложки использован рисунок П.Ф. Бореля «Литературный вечер у П.А. Плетнёва» (1892)

Публикация без редакционной обработки в Издательстве Лодзинского университета

(C) Copyright by Barbara Olaszek, Łódź 2016

(c) Copyright for this edition by Uniwersytet Łódzki, Łódź 2016

Издательство Лодзинского университета

I издание. W.07032.15.0.M

Изд. лист 11,2; печ. лист 13,875

ISBN 978-83-8088-136-5

e-ISBN 978-83-8088-137-2

Издательство Лодзинского университета

90-131 Лодзь, ул. Линдлея 8

www.wydawnictwo.uni.lodz.pl

e-mail: ksiegarnia@uni.lodz.pl

тел. (42) 6655863 


\section{ОГЛАВЛЕНИЕ}

Часть І. ПОСТАНОВКА ВОПРОСА 7

Глава І. О предрасположенности русских к спорам 9

Глава II. Теоретико-концептуальная основа исследования 23

Часть II. УЧАСТНИКИ, ТЕМЫ И РЕЗУЛЬТАТЫ «РУССКИХ СПОРОВ» 35

Глава III. «Мышление поколениями» 37

Глава IV. Споры о принципах 59

IV.1. Спор в комедии Грибоедова Горе от ума 59

IV.2. Споры в монологическом романе 61

IV.3. Споры в полемическом романе $\quad 75$

IV.4. Споры в полифоническом романе Достоевского 104

IV.5. Споры в рассказах Чехова 124

IV. 6. Итоги 135

Глава V. Споры о обустройстве России 137

V.1. Споры преддекабристского периода 137

V.2. Споры о путях развития николаевской России 140

V.3. Споры вокруг Великих реформ 143

V.4. Отражение опыта российской действительности в спорах 1870-х годов 167

V.5. Споры вокруг общественных программ последней четверти века 182

V.6. Споры на политические темы начала XX века 194

V.7. Итоги 197 
«РУССКИЕ СПОРЫ» В ХУДОЖЕСТВЕННОМ ДИСКУРСЕ КЛАССИКОВ

ЗАКЛЮЧЕНИЕ

ИСПОЛЬЗОВАННАЯ ЛИТЕРАТУРА

PEЗЮME 
ЧАСТЬ I

ПОСТАНОВКА

BOПРОСА 



\section{О предрасположенности русских к спорам}

Общественное бытие человека определено диалогическими отношениями с другими людьми. Диалог в современном мире является наиболее предпочтительной формой общения. Он - средство достижения понимания между индивидами и поэтому сам по себе является ценностью. Способы и приемы ведения диалога занимали мыслителей античности, которых волновало достижение истины или увлекало само искусство диалога. Однако, как в прошлом, так и сейчас, на пути к взаимопониманию участников диалога появлялись и появляются различные препятствия, которые преображают диалог в спор.

В середине XIX века Владимир Даль дал в Толковом словаре живого великорусского языка следующую дефиницию спора:

Спор, словесное состязание, устное или письменное прение, где каждая сторона, опровергая мнение противника, отстаивает свое ${ }^{1}$.

Понятие спора истолковано им в выражениях: «спор о словах, пустой», «спор на да и нет, голословный, бездоказательный», «спор сердия и думки, разлад ума и воли», «у них вечные споры да перекорыл», «спор дороже денег», «спор себя дороже», «за спором дело стало. Не ради дела, а ради спора»2, свидетельствующих о значении спора в русской культуре.

Можно сказать, что лексема «спор» осмысливает общественный опыт отдельной личности и коллектива. Отображая сложные межчеловеческие отношения, спор основывается на ментальности и национальных стереотипах, т.е. спор культурологически и исторически обусловлен. Так как

1 В. Даль, Толковый словарь великорусского языка, т. IV, Изд. «Русский язык», Москва 1980, с. 296.

2 Там же. 
противоречия русского бытия находили отражение в литературе и философской мысли ${ }^{3}$, то при изучении спора как проявления исторических, мировоззренческих, политических и нравственных противоречий, а также спора как проявления национальной психологии, целесообразно опираться на литературу, в особенности на классический реалистический роман. В ситуации непрерывного цензурного преследования свободного слова именно литература, благодаря метафорическому потенциалу художественного слова, становилась платформой политических споров, полем борьбы за разные концепции прогресса, за права «униженных и оскорбленных», за права женщин, за обновление искусства. К исследованию спора подвигают многочисленные высказывания самих писателей и героев, рассеянные по страницам произведений.

Начнем обзор с Александра Пушкина. В Евгении Онегине - художественной «энциклопедии русской жизни», читаем о расположенности героев к спорам, о том, что их предметом было буквально все: история, знание, нравственность и философская онтология:

Меж ими все рождало споры

И к размышлениям влекло:

Племен минувших договоры,

Плоды наук, добро и зло,

И предрассудки вековые,

И гроба тайны роковые,

Судьба и жизнь в свою череду,

Все подвергалось их суду4.

Почти параллельно с романом Пушкина Александр Грибоедов в комедии Горе от ума констатировал, что в условиях патриархального общества спор-диалог невозможен. Любые проявления свободной самостоятельной мысли, ведущие к конфронтации мнений воспринимались московскими стародумами как формы бунта. Фамусов, заметив независимость суждений Чацкого, в страхе за последствия его речей просил его молчать в присутствии солидного обывателя Скалозуба:

3 Н. Бердяев, Судьба России, Изд. МГУ, Москва 1990, с. 11.

4 А.С. Пушкин, Собрание сочинений в восьми томах, т. V, Изд. Художественная литература, Москва 1969, с. 55. 
Пожало-ста при нем не спорь ты вкривь и вкось

И завиральные идеи эти брось 5 .

В ответ Чацкий иронически успокаивал Фамусова: «Длить споры не мое желанье» ${ }^{6}$, но вопреки этому заявлению, продолжал отстаивать свою точку зрения на злободневные темы.

В разговоре с Молчалиным он затронул вопрос права личности на собственное мнение и возможность его выражения. В отличие от Чацкого Молчалин строил свою карьеру на подчинении мнению вышестоящих лиц:

В мои лета не должно сметь

Свое суждение иметь 7 .

На это признание «европеец» Чацкий ответил репликой, утверждающей право личности на самостоятельность и независимость мнений, предполагавшей спор как путь к истине:

Помилуйте, мы с вами не ребяты;

Зачем же мнения чужие только святы?8

Голос Чацкого - проявление личностного начала, без которого не было бы спора. В диалогах других персонажей пьесы всплывает проблема бесцельного спора. Фамусов, апологет московской старины, с одобрением отметил, что старики спорят не с целью что-то изменить, а ради развлечения.

....А придерутся

К тому, к сему, а чаще ни к чему,

Поспорят, пошумят, и..., разойдутся9 ${ }^{9}$

5 А. С. Грибоедов, Горе от ума, Изд. Детская литература, Москва 1969, с. 48.

6 Там же, с. 48.

7 Там же, с. 67.

8 Там же, с. 68.

9 Там же, с. 45. 
Чацкий воодушевлен идеей служения делу обновления родины и, в отличие от хранителя старины Фамусова, нацелен на результат. Не добившись взаимопонимания со стороны собеседников, он не поступился принципами, а оскорбленный в личных чувствах покинул Москву, обретая себя на скитальчество. Это можно объяснить антропологической установкой писателей романтиков, в произведениях которых личность принципиально не примиряется с противниками. Она спасается от пошлости среды бегством, как Чацкий, или иронией, как Онегин. Последний, вопреки длинному списку спорных вопросов, сам - не полемист, а снисходительный, не подвергающийся эмоциям слушатель, отвечавший иронией на излишнюю увлеченность собеседника:

Он охладительное слово

В устах старался удержать.

И думал: глупо мне мешать 10.

Подход героя к спору связан с эстетической установкой Пушкина - горацианским отрешением поэта от земной суеты. В стихотворении Я памятник себе воздвиг нерукотворный... лирическое $Я$ апеллирует к Музе быть сдержанной и не вступать в спор с глупцом:

Хвалу и клевету приемли равнодушно

И не оспоривай глупца ${ }^{11}$.

То же самое можно сказать о персонажах романтических произведений Михаила Лермонтова. Например, в романе Герой намего времени Печорин, находясь в конфликтных отношениях со средой, не вступил в вербальный спор с ее представителями, но углубился в себя, защищаясь от реальных и потенциальных собеседников иронией.

В изображении Николая Гоголя предрасположенность к спору является индивидуальной чертой характера. В Повести о том, как поссорился Иван Иванович с Иваном Никифоричем конфликт между соседями породил не спор, но ссору.

10 А.С. Пушкин, «Собрание сочинений в восьми..., т. V, с. 55.

11 Там же, т. III, с. 332. 
В Мертвых душах изображение поведения героев в ситуации спора нужно автору для обнаружения в персонажах психологических черт подхалимства и непоследовательности:

По окончании игры спорили, как водится, довольно громко. Приезжий наш гость также спорил, но как-то чрезвычайно искусно, так что все видели, что он спорил, а между тем приятно спорил. [...] Чтобы еще более согласить в чем-нибудь своих противников, он всякий раз подносил им всем свою серебряную с финифтью табакерку, на дне которой заметили две фиалки, положенные туда для запаха ${ }^{12}$.

Оказавшись в конфликтной ситуации герои были неспособны отстоять свое мнение в споре. Например, зять Ноздрева, по прозвищу Белокурый, был:

...один из тех людей, в характере которых на первый взгляд есть какое-то упорство. Еще не успеешь открыть рта, как они уже готовы спорить и, кажется, никогда не согласятся на то, что явно противуположно их образу мыслей, что никогда не назовут глупого умным и что в особенности не согласятся плясать по чужой дудке; а кончится всегда тем, что в характере их окажется мягкость, что они согласятся именно на то, что отвергали, глупое назовут умным и пойдут потом поплясывать как нельзя лучше под чужую дудку, словом, начнут гладью, а кончат гадью ${ }^{13}$.

Предрасположенность к спору обнаруживается в ситуациях, в которых герои переставали контролировать свое поведение. Чичиков и помещики, оказавшись в гостях у полицмейстера, «...спорили, кричали, говорили обо всем, об политике, об военном даже деле, излагали вольные мысли, за которые в другое время сами бы высекли детей» ${ }^{14}$.

Спору отведена одна из глав Выбранных мест из переписки с друзвями. Гоголь отметил в ней увлеченность спорами представителей двух главных идейных группировок «славянистов и европеистов», стремившихся

12 Н.В. Гоголь, Собрание сочинений в шести томах, т. V, Гос. изд. Художественная литература, Москва 1949, с. 16.

13 Там же, с. 69.

14 Там же, с. 151. 
убедить общество в преимуществе европейского или русского начал. Примечательной чертой споров в данном случае являлась увлеченность и упорство участников. Стороны были убеждены в своей правоте и не способны к компромиссу. Автор Bъıбранных мест... считал, что спорить к лицу только молодым людям - «передовым крикунам». По его мнению, люди пожилые и мудрые, не должны спорить. Из уст старика «должно исходить слово благостное, а не шумное и спорное». На основании приведенных цитат можно заключить, что Николай Гоголь не придавал должного значения спору, что можно объяснить проповедническим духом его произведений, ибо, как считает современный логик, «у призывов и проповедей нет ничего общего со спорами» 15 .

Иную точку зрения продемонстрировал Иван Гончаров, романы которого построены на диалогическом конфликте. Немаловажное значение в споре из-за принципов, проходящим между романтиком и прагматиком в романе Обыкновенная история (1847) имело искусство ведения спора. Прагматичный дядя легко устранял любое противоречие и достигал своей цели. Неопытный племянник руководствовался в споре не аргументами, а эмоциями и постоянно терпел поражение, что в конце концов заставило его уклоняться от прямого спора с дядей.

Интерес к спору как форме презентации идейных положений обнаружился в период появления и активности славянофилов и западников, на эмбриональном этапе развития политической кружковой культуры, о чем Александр Герцен писал в Былом и думах:

Наш небольшой кружок собирался часто то у того, то у другого, всего чаще у меня. Рядом с болтовней, шуткой, ужином и вином шел самый деятельный, самый быстрый обмен мыслей, новостей и знаний; каждый передавал прочтенное и узнанное, споры обобщали взгляд, и выработанное каждым делалось достоянием всех. Ни в одной области ведения, ни в одной литературе, ни в одном искусстве не было значительного явления, которое не попалось бы кому-нибудь из нас и не было бы тотчас сообщено всем ${ }^{16}$.

15 А.А. Ивин, Логика, Москва 2002, Изд. «ФАИР-ПРЕСС», гл. ХІV. [Электронный ресурс] http://psylib.org.ua/books/ivina01/txt14.htm [30 октября 2014].

16 А. Герцен, Собрание сочинений в восьми томах, т. V, Изд. «Правда», Москва 1975, c. 192. 
В его художественных мемуарах в роли персонажей изображены исторические лица. Герцен называл имена особо яростных спорщиков, например, Алексея Хомякова, всегда готовых вступать в запутаннейший спор. Интересно звучит авторская характеристика этого теоретика славянофилов, в чертах которого «выражалось что-то затаенное и какое-то азиатское простодушное лукавство вместе с русским себе на уме». При этом, в оценке Герцена, у Хомякова не было глубоких убеждений и серьезной аргументации в спорах, только одни уловки. Вспоминая поведение Михаила Бакунина в шестидесятые годы, в более поздний период обострения идейной борьбы, Герцен отмечал его расположение к спору, но не к диалогу-согласию, а к арбитральному разрешению спорных вопросов. Собственную позицию в спорах на волновавшие русских темы он оценивал критически, упрекая себя в нетерпимости и заносчивости. Желание спорить и личные качества реальных лиц, мешавшие добросовестным спорам, свидетельствует о стирании отличия между реальным спором и художественной ситуацией спора, между реальными и фиктивными спорщиками.

Пристрастие к спорам отличает героев романов Ивана Тургенева. В романе Рудин Лежнев характеризуя обстановку в кружке Покорского, отметил атмосферу споров, царившую в среде бывших товарищей. Он вспоминал, что Рудин «никогда не отказывался толковать и спорить с первым встречным». В Дворянском гнезде два героя, Михалевич и Лаврецкий, встретившись, спустя несколько лет после окончания университета, тут же заспорили:

Четверти часа не прошло, как уже загорелся между ними спор, один из тех нескончаемых споров, на который способны только русские люди. С оника, после многолетней разлуки, проведенной в двух различных мирах, не понимая ясно ни чужих, ни даже собственных мыслей, цеплялись за слова и возражая одними словами, заспорили они о предметах самых отвлеченных, - и спорили так, как будто дело шло о жизни и смерти обоих: голосили и вопили так, что все люди всполошились в доме.... ${ }^{17}$

17 И.С. Тургенев, Собрание сочинений в двенади,ати томах, т. II, Государственное издательство Художественной литературы, Москва 1954, с. 215-216. 
Увлеченность спором возросла в шестидесятые годы - время идеологической поляризации русского общества. Она нашла отражение в романах о нигилистах и новых людях. Хрестоматийным примером могут служить те романы Тургенева, герои которых постоянно спорили друг с другом, а повествователь назвал эту черту характерологической доминантой русских людей. Например, героиня романа Отиьь и дети Ивана Тургенева Одинцева считала себя «ужасной спорщицей» и предлагала Базарову: «давайте поспоримте о чем-нибудь». Базаров не видел в собеседнице черт маститого спорщика. Он считал ее женщиной слишком сдержанной в проявлении неизбежных в споре эмоций, однако, не уклонился от предложения поспорить. Спорящая женщина, равноправный партнер мужчины - это новация в русской культуре, в которой доминировало мужское начало.

Также в романе Новь рассказчик отметил пристрастие к спорам русской молодежи. Герои обожали разговоры, «те ночные, неутомимые русские разговоры, которые в таких размерах и в таком виде едва ли свойственны другому какому народу» ${ }^{18}$. Можно предположить, что «ночные русские разговоры» стали особо популярными в ситуации радикализации народнического движения и отражали этап подпольной кружковой деятельности. Молодые радикалы были расположены не к мирному спору, а к спору-борьбе, предвещавшему силовое разрешение назревших проблем. Например, Маркелов «раздражился, хотя никто ему не противоречил», он проявлял сильные эмоции и звал к насильственным мерам в устранении существующих разногласий.

Толстовские герои часто участвовали в спорах, чтобы выяснить запутанные вопросы. Те среди них кто был проницательнее, не верили в возможность достижения истины в споре и расчитывали на интуицию.

В полемическом романе Николая Лескова Некуда основным занятием героев-подпольщиков являлись идейные споры. Один из них констатировал: «У нас все так, что поспоришь, то будто как и дело сделаешь» 19.

18 Там же, т. IV, с. 292.

19 Н.С. Лесков, Полное собрание сочинений, т. IV, Изд. «А.Ф. Маркс», С.-Петербург 1897, с. 81. 
О предрасположенности к спорам героев Достоевского свидетельствуют их признания, рассеянные по страницам романов. В романе Идиот Келлер признался Мышкину в пристрастии к спору и завидовал англичанам свободы слова:

- Я удивительно люблю все эти споры и раздражения, князь, ученые, разумеется, - пробормотал между тем Келлер, в решительном упоении и нетерпении ворочаясь на стуле, - ученые и политические, - обратился он вдруг и неожиданно к Евгению Павловичу, сидевшему почти рядом с ним. - Знаете, я ужасно люблю в газетах читать про английские парламенты, то есть не в том смысле, про что они там рассуждают (я, знаете, не политик), а в том, как они между собой объясняются, ведут себя, так сказать, как политики: „благородный виконт, сидящий напротив”, „благородный граф, разделяющий мысль мою”, „благородный мой оппонент, удививший Европу своим предложением", то есть все вот эти выраженьица, весь этот парламентаризм свободного народа - вот что для нашего брата заманчиво! Я пленяюсь, князь. Я всегда был артист в глубине души, клянусь вам, Евгений Павлыч 20.

Героев Братьев Карамазовых не прельщали политические споры. Они недоумевали, почему «русские мальчики», в отличие от своих европейских ровесников встретившись, спорят о «вековечных вопросах».

Вся молодая Россия только лишь о вековечных вопросах теперь и толкует. Именно теперь, как старики все полезли вдруг практическими вопросами заниматься ${ }^{21}$.

«Русский мальчик» Иван раскрывает перед Алешей содержание «русских споров». Он уверен, что его ровесники, встретившись, будут рассуждать о «проклятых вопросах»:

О мировых вопросах, не иначе: есть ли бог, есть ли бессмертие. А которые в бога не веруют, ну, те о социализме, и об анархизме заговорят, о переделке всего человечества по новому штату, так ведь это один же

20 Ф.М. Достоевский, Собрание сочинений в десяти томах, т. VI, Государственное издательство Художественной литературы, Москва 1957, с. 422.

21 Там же, т. IX, с. 303. 
черт выйдет, все тот же вопрос, только с другого конца. И множество, множество самых оригинальных мальчиков только и делают, что о вековечных вопросах говорят у нас в наше время... 22

Рефлексию на тему спора находим и у Михаила Салтыкова-Щедрина. Писатель, прибегая к конвенции сказки о животных (Карась-идеалист, 1884), изобразил спор идеалиста со скептиком (карася с ершем) на тему возможности общественной гармонии между антагонистическими классами. Финал спора, изображенного в сказке Карась-идеалист, сопровожден пуантом ерша, заранее убежденного в бесперспективности спора: «Вот они, диспуты-то наши, каковы!»23. Мораль, наряду с заглавием, в котором главный спорщик назван идеалистом, отражает позицию автора - разочарование в диалоге как способе решения общественных конфликтов, который как правило решался силовым образом, т.е. сильный поглощал слабого.

В разбросанных по рассказам Антона Чехова замечаниях на тему спора, заметно снижается присущий последнему пафос. В раннем рассказе Задача (1887) ставится под сомнение общественный смысл юридических и политических споров в ситуации низкого уровня правовой и политической культуры. В рассказе Верочка (1887) говорится о нескончаемых русских спорах, участники которых не понимают друг друга, противоречат себе и по ходу меняют тему. В рассказе Учитель словесности (1894) повествователь остроумно охарактеризовал одну из героинь:

Всякий разговор, даже о погоде, она непременно сводила на спор. У нее была какая-то страсть - ловить всех на слове, уличать в противоречии, придираться к фразе 24 .

Подобное замечание найдем в повести Моя жизнь (1896), у героя которой была манера «всякий разговор сводить на спор». В повести Три года (1895) споры являлись видом развлечения и наравне с другими видами забавы

22 Там же.

23 М.Е. Салтыков-Щедрин, Избранное, Изд. «Современник», Москва 1976, c. 469.

24 А. П. Чехов, Полное собрание сочинений и писем в тридиати томах. Сочинения, Изд. «Наука», Москва 1985, т. VIII, с. 314. 
входили в программу вечера. В другом рассказе Ариадна (1895) повествователь иронически высказался на тему «русских споров» заметив, что русские, в отличие от немцев и англичан, которых занимают бытовые вопросы, затрагивают только высокие темы и говорят о них с пафосом: «Мы так интеллигентны, так важны, что изрекаем одни истины и можем решать вопросы только высшего порядка» 25 .

В восьмидесятые годы и в последующее время преобладают кружковые подпольные споры. Спор становится составляющей стиля жизни молодых радикалов. Подтверждением этого тезиса может служить стихотворение поэта поколения 1880-х гг. Семена Надсона Mь спорили долго... (1882), отражавшее высокий тонус споров тогдашних кружков:

Мы спорили долго - до слез напряжения...

Мы были все в сборе и были одни;

А тяжкие думы, тоска и сомненья

Измучили всех нас в последние дни...

[...]

Но странно: собратья по общим стремленьям

И спутники в жизни на общем пути, -

С каким недоверьем, с каким озлобленьем

Друг в друге врага мы старались найти!.. 26

Атмосферу тех же времен изобразил Евгений Чириков - автор семейной хроники Отчий дом (1929-1931), жанра, сочетающего исторические факты с вымыслом. Писатель отметил предрасположенность русской молодежи к тому, чтобы «упражняться в спорах, вести так называемые умные разговоры, совершенно игнорируя окружающую действительность». По наблюдениям главного героя хроники, в исторической ситуации, сложившейся после разгрома «Народной воли», отличающейся политическим маразмом, тяготением к толстовству, культуртрегерству, «малым делам», молодые люди вели споры на почве тщеславия, ради того, чтобы показать себя «Дон Кихотами», на которых был общественный запрос. Сам автор хроники признался в слабости «пофехтовать» языком и мозгами в разговорах

25 Там же, т. IX, c. 107.

26 С.Я. Надсон, Стихотворения, сост. Е.В. Иванова, Изд. «Советская Россия», Москва 1987, с. 155. 
с молодежью. Рассказчик отметил пристрастие к спорам в среде политических активистов, оказавшихся в ссылке по произволу политической полиции времен Александра III.

Горсточка ссыльных продолжала питаться собственным соком: спорили, горячились, сходились и расходились, возвеличивали и развенчивали друг друга, судились судом чести, влюблялись, решали мировые вопросы и судьбы государства Российского... ${ }^{27}$

В другом месте рассказчик и одновременно соучастник ночных собраний поделился размышлениями на тему характера русских споров:

Поднялся бестолковый шумный хаотический спор, спор - чтобы переспорить, в котором русские интеллигенты, защитники всяческих свобод, перестают считаться с чужим взглядом и убеждением, наносят друг другу словесные оскорбления, стараются поддеть друг друга обидным словцом, когда за средствами победы теряется уже и цель ее, когда люди забывают уже, о чем они, собственно, спорят... 28

Предложенный беглый осмотр разбросанных по разным произведениям упоминаний о споре и мнений на его тему, позволяет сделать вывод, что спор был неотъемлемой чертой русской культуры и русского менталитета. Он был элементом светских бесед, философских диспутов, подпольных кружковых прений и препираний о пустяках. Споры велись в салонах, на студенческих чердаках, в философско-филологических и политических кружках, в ресторанах и даже тюремных камерах, чаще всего в условиях конспирации. Своеобразие поведения в споре, его семиотика дают основание назвать споры, изображенные на страницах произведений классиков, «русскими спорами».

На основании различных упоминаний о пристрастии русских к спорам, бурном характере споров, неожиданных поворотах, современный этнолог Андрей Яровой выдвинул тезис об агональном характере русской куль-

27 Е.Н. Чириков, Отчий дом, Изд. «Эллис Лак 2000», Москва 2010, с. 221-222.

28 Там же, с. 510. 
туры $^{29}$. Он ввел в научный оборот понятие «русский агон», отражающее пристрастие русских к спору. Ссылаясь на статью Агон в Литературной энииклопедии (1930) припомнил, что в античной греческой культуре понятие агон означало борьбу и состязание, а их формой выражения был словесный спор 30 . Яровой уточнил, что понятие агон имело в античности несколько значений: агон-борьба (стремление разрушить, уничтожить), агон-состязание (стремление превзойти, победить кого-либо в чем-либо) и агон-эрос (энергия преодоления противоположных начал борьбы и игры через любовь) ${ }^{31}$. Агон-состязание не был направлен на побеждение противника, а нес в себе игровое начало. Агон-борьба содержал в себе агрессивное, уничтожающее начало. Такая форма спора была, например, средством борьбы за политическое лидерство. Функцией агона-эроса было усмирение агрессивного начала.

Согласимся, что как в русской культуре XIX века, так и в наше время, все вышеупомянутые разновидности агона остаются в силе, ибо предметом споров в России бывало буквально все - история, наука, эстетика, нравственность, философская онтология. Возникает вопрос, способен ли русский человек при таком пристрастии к спорам, по достоинству оценить возможности спора как пути к истине, как демократической формы обсуждения и решения важных общественных вопросов, как школы терпимости?

До настоящего времени объектом научной рефлексии польской русистики была история критически мыслящих элит, споры славянофилов с западниками на историософские, политические и религиозные темы ${ }^{32}$. Философскому спору о Боге и человеке посвящено фундаментальное

29 А.В. Яровой, Агон и агональная культура, [Электронный ресурс] http:// dikoepole.com/2010/03/10/agon_kultura [10 октября 2014].

30 См.: Агон, [в:] Литературная энизклопедия, т.1, ред. В.М. Фриче, Изд. Коммунистическая академия Москва1930; Античная культура. Литература. Театр.Иискусство.Философия. Наука: Словарь-справочник, ред. В.Н. Ярхо, Изд. Высшая школа, Москва 1995, с. 19.

31 А.В. Яровой, Агон и агональная культура... [Электронный ресурс] http:// dikoepole.com/2010/03/10/agon_kultura [10 октября 2014].

32 A. Walicki, Osobowość a historia. Studia z dziejów litertury i myśli rosyjskiej, PWN, Warszawa 1959; Tegoż, Filozofia prawa rosyjskiego liberalizmu, Instytut Studiów Politycznych PAN, Warszawa 1995; Tegoż, Rosja, katolicyzm i sprawa polska, Wyd. Prószyński i S-ka, Warszawa 2002. 
исследование Гжегожа Пшебинды, основанное на русской философской мысли «от Чаадаева до Бердяева» ${ }^{33}$. «Русские споры» привлекли внимание участников польско-русских летних школ, которые в рамках «круглых столов» обсуждали темы истории и политики, тему стереотипов и сам стереотип спора.

До сих пор не изучен спор в художественной литературе, которая в XIX веке в ситуации отсутствия в России парламента и цензурных гонений периодической печати, стала каналом трансляции мнений на важные общественные темы. Поэтому, существенным дополнением исследования спора в русской культуре, может стать исследование «русских споров» в художественном дискурсе классиков, особенно в реалистическом романе, стремившимся «охватывать жизнь» во всех ее проявлениях.

Мы ставим перед собой задачу проследить, с какой целью затевались изображенные в произведениях классиков споры: ради выяснения объективной правды, т.е. с гносеологической целью, или с прагматической целью найти платформу взаимопонимания и согласия вокруг общественных тем, или для проведения точки зрения субъектов спора, самоутверждения, удовлетворения личного самолюбия, т.е. аксиологической целью, а может ради интеллектуального развлечения, т.е. с фатической целью.

Исследование содержащихся в литературе образов «русских споров» - их причин, участников, тематического содержания, идейной направленности, аргументации и, главное - итогов, позволит определить специфику русского агона и скорректировать вывод о перспективности спора как формы общественного диалога в настоящее время и в будущем. Надеемся, что обобщение результатов русских споров - компромиссов, срывов, или радикальных мер разрешения спорных вопросов, вплоть до силовых, уточнит дополнительно наши представления о русской культуре, ее бинарном или тернарном характере, в смысле, предложенном Юрием Лотманом в книге Культура и взрыв 34 .

33 G. Przebinda, Od Czaadajewa do Bierdiajewa. Spór o Boga i człowieka w myśli rosyjskiej (1832-1922), Nakładem PAU, Kraków 1998.

34 См.: Ю.М. Лотман, Семиосфера, Изд. «Искусство-СПБ», Санкт-Петербург 2001, c. 148. 


\section{Глава II}

\section{Теоретико-концептуальные основания исследования}

Изучение спора в художественной литературе представляет собой сложную задачу. До того, как приступить к ее осуществлению, необходимо уточнить современную дефиницию спора и определить методы изучения.

В Большом толковом словаре русского языка спор определен как «словесное состязание, обсуждение чего-либо, в котором каждая из сторон отстаивает свою правоту» 1 В данном определении подразумевается, что спор происходит в ситуации общения, предполагает диалогическую форму обмена мнениями, в которой говорящий (адресант, речевой субъект) обращается к слушающему (другому субъекту, адресату) с сообщением, надеясь на ответное понимание. Адресат отвечает ему, одобряя или оспаривая положения высказывания адресанта.

В жизненной практике спор вызывается недоразумением, непониманием, нежеланием учесть интересы и аргументы оппонента. Субъект спора, нарушая устоявшиеся и закрепленные в практике других субъектов привычки и представления о мире, вступает с ними в вербальные прения, целью которых является убеждение в собственной правоте. Оговоримся, что ситуация, в которой стороны спора находятся в состоянии взаимной вражды, серьезной размолвки, прибегают к перебранке, нарушают общепринятые правила межчеловеческой коммуникации, является не спором, а ссорой.

В художественном изображении спор предполагает обмен мнениями в пределах сюжетной ситуации, обрамленной словом повествователя. Для изучения так понимаемого спора имеют значение жанровые черты, место в структуре произведения, его соотношение с сюжетом и повествованием,

1 Большой толковый словарь русского языка, ред. С.А. Кузнецов, Изд. Норинт, Санкт-Петербург 2003, с. 1251. 
способы выражения авторской позиции к предмету спора, стилистическая характеристика реплик.

Спор в художественном произведении вызывается изменением обстоятельств, внешних или внутренних, нарушающих установленный и привычный порядок вещей, а также изменениями во взаимоотношениях персонажей друг с другом и с действительностью2 ${ }^{2}$ Идеи, вокруг которых шли споры, сами, как замечает Василий Щукин, «рождались в живом диалоге, в гостиной, за обеденным или картежным столом и „между умами”, то есть в группе людей, мыслящих подобным образом» ${ }^{3}$. Они проходили в виде диалогического высказывания, которое, в концепции Михаила Бахтина, изложенной в статье Проблема речевыхжанров (1952-1953), является первичным речевым жанром.

В теории Бахтина спор принадлежит к первичным речевым жанрам, относительно устойчивым типам высказывания, отличающимся единством тематического содержания, стиля и композиции ${ }^{4}$, четкими границами (имеет начало и конец $)^{5}$, сменой речевых субъектов 6 , завершенностью, открывающей возможность ответной позиции ${ }^{7}$, композиционно-стилистической формой ${ }^{8}$, адресованностью9 и экспрессивностью ${ }^{10}$.

Эти первичные жанры, - писал Бахтин, - входящие в состав сложных, трансформируются в них и приобретают особый характер: утрачивают непосредственное отношение к реальной действительности и к реальным чужим высказываниям; например, реплики бытового диалога или письма в романе, сохраняя свою форму и бытовое значение только в плоскости содержания романа, входят в реальную действительность

2 См.: Поэтика: словарь актуальных терминов и понятици, ред. Н.Д.Тамарченко, Изд. Intrada, Москва 2008, с. 265-270.

3 В. Щукин, Русское западничество. Генезис - сущность, историческая роль, Ibidem, Łódź 2001, c. 15.

4 М.М. Бахтин, Эстетика словесного творчества, Изд. «Искусство», Москва 1979, с. 237.

5 Там же, с. 250.

6 Там же, с. 254.

7 Там же, с. 255.

8 Там же, с. 270.

9 Там же, с. 279.

10 Там же, с. 258. 
лишь через роман в его целом, то есть как событие литературно-художественной, а не бытовой жизни ${ }^{11}$.

Бахтин отметил значение изучения соотношения первичных и вторичных жанров для решения проблемы взаимоотношений языка и идеологии. Оно важно при исследовании спора - составной части литературной модели мира, созданной в опоре на реальную жизнь - источник различных идеологий и идеологических языков.

Андрей Степанов в монографии Проблемы коммуникаиии у Чехова (2005) использовал теоретическую концепцию Бахтина речевых жанров, но обратил внимание на некоторую ее ограниченность. Остановимся на тех замечаниях, которые существенны для нашего исследования. Степанов отметил, что первичные жанры столь многочисленны и разнообразны, что на практике «строгим тематическим, композиционным и стилистическим единством может обладать только часть вторичных жанров - прежде всего письменных... ${ }^{12}$ Соблюдение условий «единства говорящего субъекта» и «смены речевых субъектов» исследователь считал возможным исключительно в «индивидуальных реализациях каждого жанра» ${ }^{13}$. По его мнению в жанре спора важнее смены речевых субъектов является единство тезиса. Очередной чертой бахтинской концепции первичных речевых жанров, на которой остановился Степанов, является ответная позиция адресата. В освещении Бахтина она является конститутивной чертой речевого жанра:

В самом деле, слушающий, воспринимая и понимая значение (языковое) речи, одновременно занимает по отношению к ней активную ответную позицию: соглашается или не соглашается с ней (полностью или частично), дополняет, применяет ее, готовится к исполнению и т.п.; и эта ответная позиция слушающего формируется на протяжении всего процесса слушания и понимания с самого его начала, иногда буквально с первого слова говорящего. Всякое понимание живой речи, живого высказывания носит активно-ответный характер (хотя степень этой активности бывает весьма различной); всякое понимание чревато ответом и в той

11 Там же, с. 239.

12 А.Д. Степанов, Проблемы коммуникации у Чехова, Изд. Языки славянской культуры, Москва 2005, с. 31.

13 Там же. 
или иной форме обязательно его порождает: слушающий становится говорящим („обмен мыслями”). Пассивное понимание значений слышимой речи - только абстрактный момент реального целостного активно-ответного понимания, которое и актуализуется в последующем реальном громком ответе $\mathrm{e}^{14}$.

Исследователь коммуникативных стратегий Чехова обратил внимание на то, что «ответная позиция» - «краеугольный камень теоретической бахтинской теории диалога» - неоднозначна, ибо может быть реальной или подразумеваемой.

Во-первых, в момент речи другого слушатель чувствует пока не выраженное словесно отношение к этой речи - согласие или несогласие. Во-вторых, говорящий, выступая в определенном жанре, предполагает и стремится вызвать определенную реакцию своего слушателя, и в соответствии с этим предположением и стремлением строит свою речь 15 .

Бахтин выделил несколько разновидностей реакций на реплику. Назовем те, которые свойственны спору, а именно: «вопрос - ответ», «утверждение - возражение», «утверждение - согласие». Само собой разумется, что характер реакции зависит от адресата, «предполагаемого адресата» в терминологии Бахтина.

Вопросы значения адресата и «ответной позиции» нашли дальнейшее истолкование в трудах современных иследователей. В модели коммуникации, предложенной польскими лингвистами, также подчеркивается значение сторон общения - субьекта и адресата. Малгожата Кита, ссылаясь на французскую исследовательницу Катерину Кербрат-Орекхиони, поставила акцент на интерактивную теорию коммуникации, диалогический характер дискурса, значение в нем адресанта и адресата, обладающих идеологическими и культурологическими компетенциями ${ }^{16}$, особо важными для оценки результатов спора.

14 М.М. Бахтин, Эстетика словесного творчества, с. 246.

15 А.Д. Степанов, Проблемы коммуникации у..., с. 31.

16 C. Kerbrat-Orecchioni, L'Enonciaton. De la subiektivite dans le language, Paris 1980, цит.по: M. Kita, Wywiad prasowy. Jezyk - gatunek - interakcja, Wyd. Uniwersytetu Śląskiego, Katowice 1998, s. 23. 
Для исследования художественного дискурса имеет значение комуникативная стратегия, в которой дискурс понимается как коммуникативное событие, разыгрывающееся между разными субъектами. По определению Валерия Тюпы:

Коммуникативное событие является одним из параметров текстопорождения. Инициатор коммуникативного события навязывает ему типовую интенциональность его коммуникативного поведения. Смена стратегии почти всегда возможна, но переход к новой коммуникативной стратегии неизбежно означает прерывание одного высказывания и начало другого ${ }^{17}$.

Значение, какое придается коммуникативному событию может быть существенным при исследовании художественного дискурса. Дискурсный анализ предполагает исследование различных коммуникативных событий и риторических приемов их участников.

При исследовании художественного дискурса классиков необходимо учитывать индивидуальные способы речевого реагирования на реплики в споре, т.е. стиль высказываний, в особенности метафоры как способ отражения опыта восприятия действительности. В этом плане сошлемся на когнитивную концепцию метафоры Дж. Лакоффа и М. Джонсона Meтафборь, которыми мы живем (1980). В представлении названных авторов метафора имеет концептуальный характер, так как обыденная понятийная система человека по своей природе метафорична. Это означает, что метафоры являются скорее ментальными происшествиями, чем чисто языковыми образованиями. В концепции авторов работы концептуальная метафора - это процесс, в результате которого мы структурируем повседневную деятельность, например, спор описывается не только в терминах войны, но и структурируется концептом войны ${ }^{18}$.

Для изучения спора имеет значение событийное содержание, т.е. описание обстоятельств возникновения спора и хода общения, его результаты

17 В.И. Тюпа, Коммуникативная стратегия, [в:] Поэтика: словарь актуальHolx ..., c. 100.

18 Дж. Лакофф, М. Джонсон, Метафорьь, которьми мы живем, перев. А.Н. Баранов, А.В. Морозова, Изд. ЛКИ, Москва 2007, с. 26. 
в виде решения спорного вопроса и завершение прений или их продолжение. Особо важным фактором является аксиологическая модальность ответной реакции адресата и позиция автора по отношению к предмету спора.

Объектом исследования в нашей книге станут конкретные ситуации споров, изображенные в произведениях ведущих русских писателей XIX века. Для определения их своеобразия нужно располагать некой идеальной моделью спора, которая уходит своими корнями в античную культуру. Ее воспроизвел Артур Шопенгауэр в классическом труде Эристика, или Искусство побеждать в спорах (1830). Немецкий философ в разработке эристических приемов в споре следовал за греческим ученым Максимосом, автором труда Peri alyton anthitheseon. В попытке осмысления природы спора Шопенгауэр обратился к античной традиции философских диалогов Платона, отметив, что в них сталкиваются не только мнения, но и их носители, а также отнесся к софистическим спорам.

Софистический спор был основан на протагорейском принципе homo mensura, нарушающем критерий объективной истины. Этот принцип стал основанием тезиса о том, что противоположные суждения могут иметь одинаковую ценность. Целью софистического спора не был поиск истины, а достижение победы в словесном состязании. Критику приемов софистов в споре дал Аристотель в труде О софистических опровержениях. Философ видел главную цель диспута в поиске истины. Он отделил диалектику от софистики и эристики - искусства быть правым во всех спорах. Принципы спора были изложены Аристотелем в его Риторике.

Знание приемов спора и всевозможных уловок имело практическое значение для логиков, юристов, писателей, публицистов. Шопенгауэр отметил во вступлении к Эристике, что у каждого человека есть природная диалектика и талант убеждения, но не менее важны упражнения в искусстве вести спор:

В начале спора каждый из противников убежден, что правда на его стороне, во время же спора оба начинают колебаться, конец же спора должен выяснить правду и подтвердить ее ${ }^{19}$.

19 А. Шопенгауэр, Эристика, или искусство побеждать в спорах, [Электронный ресурс] http: www//Home.arcor.de/rushbone/eristik.html [19 ноября 2014]. 
Эти слова свидетельствуют о том, что Шопенгаэур склонялся к аристотелевскому пониманию цели спора, но при этом придавал большое значение знанию практических навыков ведения спора. Потому неудивительно, что основная часть книги Шопенгауэра отведена изложению сути и характера приемов и уловок в споре.

Русский перевод Эристики Шопенгауэра появился в 1864 году. Можно предположить, что русские романисты знали эту работу и могли воспользоваться нею в качестве практического руководства при моделировании споров между литературными персонажами.

В XX веке теорию спора на русской почве привил Сергей Поварнин ученый-логик с литературоведческими увлечениями, изложив ее в книге Спор. О теории и практике спора (1918) ${ }^{20}$. Во введении автор назвал Эристику Шопенгауэра «необработанным набором случайно попавшегося под руку материала». По его наблюдениям, еще в начале двадцатого века знание логических правил спора русским образованным обществом оставалось неудовлетворительным. Поварнин отметил вневременную сущность спора и необходимость овладения его приемами:

В истории человеческой мысли появление всякой великой идеи сопровождается обыкновенно бурными спорами, при чем защитники старых взглядов сперва стараются доказать, что новая «разрушительная» мысль ощибочна. Если истинность ее стала вне сомнений, они переходят ко второму способу защиты: стараются показать, что она совместима со старыми мыслями ${ }^{21}$.

Исходя из положений предшественников, Поварнин обучал читателей умению защищать свою правоту и убеждать в ней противника. Несмотря на то, что его книга была написана в 1918 году, сегодня она воспринимается как современное пособие по эристике и искусству спора 22 . В настоящее время книга Поварнина представляет собой нечто вроде практического

20 В. И. Аннушкин, Классическая книга в духе эпохи и современном стиле, [в:] С.И. Поварнин, О теории и практике спора, Изд. «Флинта», Изд. «Наука», Москва 2009, с. 110.

21 С.И. Поварнин, Спор. О теории и практике.., с. 38.

22 В.И. Аннушкин, Классическая книга в духе..., с. 110-111. 
руководства для читателей, незнакомых с логикой. Для нас ценность ее заключена в доступном изложении эристических приемов спора. Например, важное значение имеет вопрос границ спора, его прекращения и завершения: «Завершение спора не то же, что конец спора»23. Также причины прекращения спора могут носить случайный характер и оказаться значительно важнее причин его незавершения. «Завериается же спор тогда, когда одна из сторон отказывается от своей точки зрения на тезис, убеждена противниками» 24 . В этом плане нас особо интересует «статистика» умышленных прекращений споров, которая позволит сделать заключение о причинах незавершенности изображенных в литературе споров: тактике спорщиков в конкретной ситуации или, как можно предположить, неумении найти ими решения спорных проблем.

Поварнин предложил список уловок, применяемых в споре - психологических, логических и языковых. Для исследования литературных ситуаций спора особое значение имеют психологические факторы (оскорбление противника, глумление, издевательства, с одной стороны, и лести, - с другой), тактика (внушение, ораторский пафос), языковые средства (тропы и риторические фигуры), логические уловки, такие как подмена спора изза тезиса (выяснение истины) спором из-за доказательств, а тоже перевод предмета спора с дела на личность оппонента, диверсия, т.е. подмена тезиса или довода в ходе спора и т.д.

Логическая модель спора, предложенная Поварниным, может оказаться не вполне подходящей для исследования литературной модели, которой свойственны специфические художественные приемы спорить. Попытку создания контуров идеальной модели жанра предпринял Степанов в упоминаемой монографии Проблемы коммуникации у Чехова. В главе Информативно-афбективные жанры. Спор. Герой и идея, отталкиваясь от бахтинской теории, исследователь определил гипотетическую модель идеального спора и его условия:

Идеальный спор - это диалог, в котором один из говорящих предлагает некий тезис (или даже развернутую концепцию), а собеседник приводит факты, этому тезису противоречащие, или выявляет его логические по-

23 С.И. Поварнин, Спор. О теории и практике..., с. 49. Курсив автора - Б.О. 24 Там же. 
грешности, выдвигая тем самым антитезис. Антитезис по отношению к тезису является контрарным или контрадикторным (т.е. противоположным или противоречащим). Затем первый указывает на ошибки в опровержении и т. д. Таким образом, (диа)логическая структура спора предстает как опровержение опровержения опровержения. При этом, развиваясь за счет частностей, спор всегда остается центрированной системой: в нем есть главный тезис, который выдвигает инициатор и пытается опровергнуть его противник. Все аргументы сторон нацелены на этот тезис и логически связаны с ним. Границы спора как высказывания определяются, конечно, не сменой речевых субъектов, а единством тезиса: один тезис - один спор. Сам тезис в идеале отражает некие общие идеи, принципы говорящих. Благодаря этому спор включается в «большой диалог», из чего, в свою очередь, следует невозможность полного завершения спора 25 .

Исследователь полагает, что в идеальном споре стороны в равной степени знают предмет спора, владеют логикой и приемами, одинаково заинтересованы в выяснении истины и готовы к компромиссу. Опираясь на опыт исследования чеховских рассказов, Степанов пришел к выводу, что идеальной модели в практике не существует. По его наблюдениям, отступления от идеальной модели превращают спор в риторическое убеждение и сдвигают его из разряда информативных жанров в разряд жанров аффективных. Цель последних - не выяснение истины, а убеждение противника в своей правоте.

Соотнесение конкретных литературных реализаций спора с образцовой моделью позволит сделать соответствующие выводы относительно перспективности спора как надежного способа решения спорных проблем общенационального значения и перспективности диалога как формы общественной коммуникации. Для осуществления последней задачи придется определить сам характер спора, добросовестного или софистического. В осуществлении этой задачи большое значение имеет оценка приемов, эристических уловок в споре.

С точки зрения осуществления намеченной нами цели - исследования спора во вторичных жанрах, особенно в романе, имеет значение его выделение в потоке повествовательной речи. Оно может оказаться трудным,

25 А.Ф. Степанов, Проблемь коммуникации у.., с. 123-124. 
поскольку, как было отмечено выше, на практике идеального спора не существует. Спор в художественном произведении не всегда имеет вид диалога героев, синтаксически независимого от речи повествователя, т. е. он не всегда подан в форме прямой речи. Иногда содержание и ход спора излагаются повествователем с использованием несобственно-прямой или косвенной речи. Для различения слова повествователя и персонажа-спорщика пригодной может оказаться стилистическая характеристика речи, приобретавшая в жанре спора экспрессивный и модальный характер ${ }^{26}$.

Спор, являясь своеобразным коммуникативным событием, относится к сюжету. Предложение отнести особую форму диалога, каковой является спор, к сюжету может показаться методологически сомнительным, но припомним, что диалог во вторичных жанрах, это - «событие общения 27 , связанное с опережающими и последующими за ним событиями ${ }^{28}$. Таким образом, спор укоренен в системе событий, т.е. имеет событийный характер.

Итак, в нашем исследовании спор понимается как речевой жанр, используемый в художественном произведении в пределах сюжетной ситуации. Ведущие классики на страницах своих произведений ставили героев в конфликтные ситуации и заставляли решать спорные вопросы. На материале русской литературы XIX века, прежде всего эпических жанров, будут проанализированы: цель споров и причины их возникновения, состав участников, тематика, идейное содержание, сам ход спора и риторические приемы его ведения и, наконец, результаты.

Перечитав произведения с точки зрения изображения споров, мы выделили две главные тематические разновидности: споры о принципах и споры об обустройстве России. Исходя из кантовской установки о первенстве сознания перед бытием, в первую очередь будем рассматривать споры о принципах. Затем последует анализ споров об

26 G. Borkowska, Dialog jako kategoria poetyki, [w:] Problemy teorii literatury, seria 4, wybór H. Markiewicz, Wyd. Zakład Narodowy im. Ossolińskich, WrocławWarszawa-Kraków 1998, s. 205-245.

27 В.И. Тюпа, Коммуникативная стратегия, [в:] Поэтика: словарь актуальHblx..., c. 100.

28 G. Borkowska, Dialog jako kategoria..., s. 223. 
общевенном и политическом устройстве России, главной темой которых были представления сторон о характере и путях прогресса, его ведущих силах.

Изложение содержания споров об обустройстве России потребует другого принципа презентации материала, чем тот, который задуман для главы Споры о принцииах. Споры по поводу политических и экономических вопросов вызывались конкретными фактами и были своеобразным к ним комментарием. Поэтому будем их рассматривать в отношении к конкретной исторической ситуации и с нарушением хронологии написания отдельных произведений.

Тематический принцип изложения обширного материала, каким являются произведения классиков XIX века, не может быть идеальным, ибо угрожает повторами в процессе истолкования. Однако он поможет, как нам кажется, лучше разобраться в приоритетах русской интеллигенции и оценить общественное значение результатов споров.

Пользуясь социокультурным и дискурсивным методами анализа, мы рассмотрим комплекс вопросов, затронутых в спорах в их отнесении к общественно-историческому контексту. Дискурсный метод анализа позволит рассмотреть взаимоотношения говорящего субъекта и адресата высказывания в ситуации общения. Анализируя ход споров, изображенных на страницах литературных произведений постараемся определить позицию авторов произведений в отношении затронутых спорных тем и уточнить их взгляды на ключевые «русские вопросы».

Осуществление задачи определения авторских позиций к предмету споров пройдет с учетом типологии романа монологического и полифонического, предложенной Михаилом Бахтиным в известной работе Проблемь поэтики Достоевского 29 . Бахтин уделил в ней внимание значению отношения автора к говорящему герою. Оно стало критерием предложенного ученым деления на монологический роман, в котором «голоса» героев подчинены авторскому сознанию, и полифонический роман, в котором они равноправны. Бахтинская типология была использована и развита в работах других авторов.

29 М. Бахтин, Проблемы поэтики Достоевского, «Художественная литература», Москва 1972. 
Наталья Старыгина ввела в научный оборот понятие полемический роман $^{30}$ подходящее для наших исследований как более широкое и менее ригористическое, чем определение антинигилистический роман ${ }^{31}$. В полемическом романе словам героя поручалась задача передачи нравственных, философских и политических идей, их утверждения или опровержения, что часто происходило в виде спора.

В исследованиях спора учтем все три разновидности романа. Реалистический роман является в нашем исследовании главным, но не единственным зеркалом «русских споров». Наши рассуждения начнем с комедии Александра Грибоедова Горе от ума - произведения, отразившего «слом эпох», и завершим семейной хроникой Николая Чирикова Отчий дом, которая отражает крайнюю точку эволюции русских споров в XIX веке, особенно политических, а также их последующий переход в партийные споры.

Надеемся, что результаты анализа литературных изображений спора помогут найти ответ на вопрос о том, какая разновидность спора - плодотворного диалога-согласия, направленного на выработку истины, или недобросовестного спора ради победы над противником, или же спораигры преобладает в русской культуре. Они помогут в определении причин препятствий в общественной коммуникации и обозначении перспективы спора в будущем.

30 Н.Н. Старыгина, Русский полемический роман 1860-1870-х годов в ситуации философско-религиозной полемики, Изд. Языки славянской культуры, Москва 2003.

31 См.: Ю.С. Сорокин, Антинигилистический роман, [в:] История русского романа, т. II, Изд. Наука, Москва 1969, с. 97-120. 
ЧАСТЬ II

УЧАСТНИКИ, ТЕМЫ

И РЕЗУЛЬТАТЫ

«РУССКИХ СПОРОВ» 



\section{Глава III}

\section{«Мышление поколениями»}

Спор как форма общения предполагает смену речевых субъектов. Поэтому, небезынтересно задуматься над тем, кто участвовал в «русских спорах», и начертить общие портреты сторон. Первое, что обращает на себя внимание - это участие в спорах представителей разных поколений, акцентирующих свое отличие от предшественников. Объектом дальнейших размышлений станет поколение как сторона спора.

Вначале отметим, что понятие «поколение» имеет разные значения: «родственники одной степени родства по отношению к общему предку», «одновременно живущие люди (особи) приблизительно одного возраста», «группа людей, близких по возрасту, объединенных общей деятельностью, общими интересами»1. Вильгельм Дильтей, чье понимание поколения закрепилось в гуманитарных науках, считал поколением тех, кто близок по возрасту, кому присущ общий исторический и культурный опыт 2 . Такое поколение ученый назвал «культурным поколением». В дальнейших рассуждениях мы будем пользоваться этим понятием, которое восприняла и русская наука ${ }^{3}$.

Особо важным для нас представляется выяснить, какое значение имело своеобразие поколенческого мировосприятия на возникновение и ход споров. Имеется в виду значение социального статуса спорщиков, основ их

1 Большой толковыцй словарь русского языка, ред. С.А. Кузнецов, Изд. Норинт, Санкт-Петербург 2003, с. 895.

2 См.: K. Wyka, Rozwój problemu pokolenia, [w:] Tegoż, Modernizm polski, Wydawnictwo Literackie, Kraków 1968, s. 431-464; Aneta Kamińska, Kategoria pokolenia we współczesnych badaniach nad społeczeństwem i kulturq-przeglad problematyki, „Kultura i Historia” 2007, № 11.

3 См.: Поколение в социокультурном контексте ХХ века, ред. Н.А. Хренов, Изд. «Наука», Москва 2005; Б. Дубин, Поколение: сочиологические границь понятия, [Электронный ресурс] http://polit.ru/article/2002/04/17/474861/6, [15 ноября 2014 г.]. 
идейной и культурной общности, литературных вкусов, кумиров, стремления стать пионерами прогресса и т.п.

Первым поколением, провозгласившим свое отличие от предшественников, было «александровское поколение» молодых образованных реформаторов, составивших Негласный комитет, подджерживавший Александра I в планах преобразования государственного устройства. Наряду с «реформаторами» проявляли активность люди консервативных взглядов, как, например Николай Карамзин, автор Записки о древней и новой России (1811). Судьбу поколения определила череда войн, в особенности - Отечественная война 1812 года как главное историческое событие первой четверти XIX века. В результате исторических обстоятельств место гражданских «реформаторов» заняли военные, Сперанского сменил Аракчеев. В оппозиции к власти оказалось молодое поколение в лице передовых офицеров, участников Отечественной войны, будущих декабристов.

Литературный образ борьбы поколений найдем в комедии Александра Грибоедова Горе от ума. В его изображении критерием принадлежности к старому или молодому поколению стало отношение к государственной службе, правительству, просвещению и науке. С одной стороны, оставались актуальными просветительские представления о значении авторитета и опыта старшего поколения, т. е. отцов:

Вот то-то, все вы гордецы!

Спросили бы, как делали отцы?

Учились бы на старших глядя: ${ }^{4}$

С другой стороны, отмечалось отсутствие авторитетов:

Где, укажите нам, отечества отцы,

Которых мы должны принять за образцы?5

В роли оппонента сомнительных авторитетов выступил представитель молодого поколения - Чацкий. Автор комедии был убежден в необходимости появления новой личности, способной нарушить царившую обще-

4 А. Грибоедов, Горе от ума, Изд. Детская литература, Москва 1969, с. 28.

5 Там же, с. 41. 
ственную и политическую стагнацию. Чацкого отличало индивидуалистическое сознание, свобода суждений и иные, чем у московских вельмож, представления о частной и государственной службе. Он, руководствуясь умом, критиковал старое поколение, которое, придерживаясь правил прошедшего века, не давало надежд на развитие. Последствием разногласий поколенческих идеалов являлся конфликт героя с косной средой, завершившийся его личным поражением. По просветительской схеме герой должен стать реформатором сознания старого поколения, но он слишком поддался эмоциям, отступал перед остракизмом среды и в конечном итоге бежал из Москвы в неопределенном направлении. Справедливо сделать заключение, что конфликт героя со средой имел просветительскую основу, а мотивировка финального поступка - бегства - романтическое обоснование. Они образуют поколенческую модель отношений, чертой которой являлась возрастная и культурная оппозиция.

В изображении поэтов-романтиков поколение являлось союзом молодых людей, которых объединяли тип образования, идеалы дружбы, красоты, литературные интересы. Чувство поколенческой общности нашло отражение в пушкинских дружеских посланиях, героями которых были товарищи-лицеисты.

Согласно ритму исторических событий, началом, сплотившим поколение повзрослевших лицеистов, стали исторические события - Отечественная война с Наполеоном, восстание декабристов и гражданские побуждения. В стихотворении Пушкина Во глубине сибирских руд (1827) чертой поколения - участников восстания декабристов, стали «свобода, любовь, дружество». К молодым, наряду с борцами за свободу, принадлежали «онегины» - русские денди. Дендизм как поведенческий стиль жизни дворянской молодежи двадцатых годов проявлялся в неприятии любых шаблонов и демонстрации индивидуализма. Дендизм ассоцировался с либерализмом, но ним не был. Онегин, несмотря на смелые планы «порядок новый учредить» в унаследованном имении, остался несостоявшимся социальным реформатором.

В трактовке Михаила Лермонтова объединяющим опытом старого поколения стало участие в битве под Бородино. В стихотворении Бородино (1837) его отличительными чертами являлись героизм и патриотизм. На отношении к этим ценностям построена оппозиция к молодому поколению. Она выражена в антитезе «богатыри - не вы». Критическая оценка со- 
временного поколения появилась и в стихотворении Дума (1838), в котором лирический герой упрекнул современное поколение в бездейственности, в том, что оно не воспользовалось историческим и жизненным опытом отцов. В оценке лирического Я поколение, с которым оно отождествляло себя, несло ответственность перед потомками за интеллектуальное бесплодие. Если в первом стихотворении межпоколенческий канал общения существовал, то во втором - связь поколений разорвана.

Концепция взаимоотношений поколений осложнена в романе Герой нашего времени (1840), главный герой которого составлен, по словам автора, «из пороков нашего поколения, в полном их развитии» 6 . В ее основе лежало сформированное под влиянием немецкой философии убеждение автора в значении посторонних, независимых от человека факторов, таких как судьба и случай. Раскрытие характера Печорина внесло существенную поправку в суждение о «порочности» поколения. Оно нашло отражение в стремлении автора найти противовес Печорину в «верных людях», руководствующихся в жизни рассудком и не верившим в предопределение или в прозаических личностях типа Максима Максимыча. Фаталист Вулич назвал дискуссию товарищей о предопределении пустым спором перед лицом бесспорности значения случая в жизни человека. Последовавшие события послужили аргументом в поддержку его тезиса о значении судьбы. Рефлексирующий Печерин, безвольный в управлении своими поступками, оказался проницательнее прозаических личностей и поставлен автором романа «героем нашего времени».

Для писателей следующей генерации Печерин стал знаковой личностью. Появилось даже определение «поколение Героя нашего времени», служащее для обозначения героев - рефлексирующих личностей, но оно употреблялось ими в отрицательном значении.

Сороковые годы - время ухода из жизни ведущих поэтов-романтиков и дебютов писателей-реалистов, характеризует не только смена литературных поколений, но и изменения в художественной модели поколения как такового. Попытку создать новую модель одним из первых предпринял Иван Гончаров. Центральное место в ней занимает переосмысление системы ценностей предшествующего поколения.

6 М.Ю. Лермонтов, Собрание сочинений в четырех томах, т. IV, Изд. Академии Наук СССР, Москва-Ленинград 1962, с. 276. 
В романе Обыкновенная история (1847) отмечен момент ощущения принципиального различия двух систем ценностей - романтической и прагматической, а затем сближения на новой основе представителей двух поколений - юного племянника и дяди, человека среднего возраста. Процесс преображения юного романтика прошел в «школе жизни» опытного родственника. Эффектом приспособления Александра к новой реальности стало его эмоциональное очерствение, превращение из «чувствительного» в «холодного»7. Выбор героем жизненного пути по образцу делового дяди отражает феномен крушения сентиментально-романтических идеалов и становление в русском обществе новых прагматических принципов. Однако вряд ли научно корректным будет приписывание черт Петра Адуева и других «деловых людей» - Штольца - героя романа Обломов (1859) или Калиновича - героя романа Тьсяча душ (1858) Алексея Писемского, целому поколению 1840-50-х годов. Доминирующими в этом культурном поколении оказались не они, а «лишние люди».

Определение «лишние люди» является концептом, авторство которого принадлежит Ивану Тургеневу. В изображении Тургенева «лишние люди» - это поколение дворян-«гамлетиков», сформировавшееся в атмосфере Московского университета и кружка Станкевича. Они - люди аналитического склада ума, поклонники искусства и немецкой философии, придерживающиеся романтических идеалов красоты, любви и добра. Их образ встречаем в романе Рудин (1856). По словам Лежнева на заседаниях кружка Покорского, который он посещал вместе с Рудиным, затрагивались вопросы «о Боге, правде, о будущности человечества, о поэзии...» ${ }^{8}$. Спустя пятнадцать лет эти идеалы стали несвоевременными. Их носителям противопоставлен Пигасов, выпускник Дерптского университета, не любивший музыку и пренебрежительно относившийся к литературе. Он враг красноречия и поклонник фактов. Поколение 1830-х годов в лицах Лежнева и Рудина взрослеет (Лежнев становится солидным хозяином, Рудин же остается неисправимым говоруном, человеком несостоявшимся в практической области), но не отказывается от идеалов молодости. В условиях

7 Имеется в виду характерологические черты, нарисованные Н.М. Карамзиным в рассказе Чувствительный и холодный (1803).

8 И.С. Тургенев, Собрание сочинений в двенадияати томах, т. II, Государственное издательство Художественной литературы, Москва 1954, т. II, с. 69. 
1850 -х годов Тургеневым обнаружена несвоевременность идеалов предыдущего поколения.

В очередном романе Дворянское гнездо писатель изобразил поколение 1830-40 годов, к которому принадлежали Лаврецкий и Михалевич. Основными чертами Михалевича являлись скитальчество и увлеченность романтическими идеалами. В Лаврецком отмечено значение просветительского типа воспитания, чем объясняется его интерес к точным наукам, увлечение роковой красавицей и разочарование в романтической любви. Лаврецкий изображен представителем поколения, ищущего для себя общественное поприще. Вернувшись из заграницы, он собирается «дело делать» в своем хозяйстве. Под делом он подразумевал улучшение быта крестьян. Однако Лаврецкий неубедителен в роли передового помещика. Он - разочарованный в любви, ищущий тишины романтик, для которого родовое имение - оазис покоя, а не поле деятельности. Подобный опыт свойственен Павлу Петровичу Кирсанову, пережившему в молодости роковую любовь к красавице, англоману, человеку принципов и высоких общественных идеалов, но бездеятельному, от которого не было пользы для bien public. Оба героя, несмотря на разницу в возрасте (Лаврецкий - человек среднего возраста, Павел Петрович - пожилой) типичные представители поколения «лишних людей», которое противопоставлено молодому поколению в двух его вариантах: деловых карьеристов и нигилистов. Лаврецкий находится на противоположном идейном полюсе, чем Владимир Николаевич Паншин - представитель столичной молодежи, светский образованный человек, успешный чиновник, щеголявший в обществе европеизмом. Он - предшественник Калломейцева, чиновника-карьериста, защитника привилегий среднего класса - «landed gentry». Голос людей этого типа прозвучал диссонансом в спорах о будущем России с представителями других общественных сил.

Смена системы ценностей поколения - это процесс, ускоряющий свои темпы на рубеже эпох. Конфликт поколений с полной остротой обнаружился в шестидесятые годы, когда на общественной сцене появилась новая сила в лице поколения разночинцев, принципиально отвергавших систему дворянских ценностей. Намеченное Тургеневым в Дворянском гнезде ощущение разногласий в понимании идеалов и задач, стоявших перед современным поколением, получило продолжение и углубленное рассмотрение в романе Oтцы и дети (1862). Разногласие преобразилось в открытый кон- 
фликт поколений. Неоспоримое первенство в его осмыслении принадлежит Тургеневу, создателю концепта «отцы и дети»9.

Роман построен на противопоставлении старого и молодого поколений. Деление героев на отизов и детей происходит не по возрастному критерию, а по общности историко-культурного опыта, влияющего на формирование определенного типа сознания. Существенное значение для его понимания имеет в романе датировка, уточняющая не только возраст героев, но и время их интеллектуального формирования. Так благодаря датам мы узнаем, что отцы - люди поколения войны с Наполеоном, получившие образование в Московском университете в период расцвета в нем свободомыслия, деятельности философско-литературных кружков, ставшие в зрелом возрасте свидетелями французской революции 1848 года. Дети - ровесники Николая Добролюбова, формировавшиеся в период пробуждения интереса к естественным наукам, увлечения социализмом, притеснений свободы в годы мрачного семилетия и начала либерального правительственного курса Александра II.

Поколение отизов определило свою идентичность в опоре на базовые для дворянской культуры принципы, такие как «аристократизм, либерализм, прогресс», увлечение искусством. Поколение детей в лицах Базарова и Аркадия Кирсанова, а также их преданных подражателей - Ситникова и Кукшиной, было поклонниками Бюхнера и Моллешота, декларировало приверженность фактам, добытым путем опыта и данным эмпирической науки, руководствовалось положениями пользы в нравственной сфере. Его программным лозунгом стало разрушение. Базаров, раскрывая подлинный характер взглядов своего спутника Аркадия, указал на обременяющий друга багаж дворянской культуры как препятствие в том, чтобы стать настоящим нигилистом:

В тебе нет ни дерзости, ни злости, а есть молодая смелость да молодой задор; для нашего дела это не годится. Ваш брат дворянин дальше благородного смирения или благородного кипения дойти не может, а это пустяки. Вы, например, не деретесь - и уж воображаете себя молодцами, а мы драться хотим. Да что! Наша пыль тебе глаза выесть, наша грязь

9 См.: Н.В. Володина, Концепты, универсалии, стереотипы в сфере титературоведения, Изд.ГОУ ВПО «Череповецкий государственный университет», Череповец 2010, с. 177-199. 
тебя замарает, да ты и не дорос до нас, ты невольно любуешься собою, тебе приятно самого себя бранить; а нам это скучно - нам других подавай! Нам других ломать надо! Ты славный малый; но ты все-таки маленький, либеральный барич... ${ }^{10}$

Базаров выдвигал в качестве программы действий постулат полного разрушения всего, что было достоянием дворянской культуры, но не предложил ничего взамен. Суть обоих поколений содержит рукописный, позже снятый Тургеневым эпиграф к роману Omuы и детu:

Молодой человек (человеку средних лет). У вас было содержание, но не было силы.

Человек средних лет. А в вас - сила без содержания» (Из современного разговора.) $)^{11}$

В диалоге представителей молодого и среднего поколений общность строится на готовности отрицания («силе») системы ценностей предшественников («содержании»). Отметим, что в качестве коммуникативного поколенческого кода предлагается сила - орудие радикальных идеологий.

Поколение, голос которого доминировал в 1860-е годы, состояло из разночинцев. Оно формировалось в атмосфере оппозиции к системным реформам Александра II и сопутствующей им активизации радикальных настроений в обществе, распространяемых организацией «Земля и воля». Для определения его облика имело значение влияние пропаганды герценовско-огаревского «Колокола» и радикальных журналов «Современник» и «Русское слово».

Создателем типа «нового человека» является Николай Чернышевский. В романе Что делать? (1863), снабженным характерным подзаголовком Из рассказов о новых людях, он изобразил последователей Базарова, назвав их «новыми людьми». Словосочетание «новые люди», считает Наталья Володина, приобрело в русской литературе статус концепта, знакового для

10 И.С. Тургенев, Собрание сочинений в двенадиати..., т. III, с. 349.

11 Там же, с. 395. 
русской ментальности ${ }^{12}$. В слове повествователя автор романа уточнил, что герои задуманы как единомышленники, с которыми читатели могли бы отождествить себя и которым могли бы подражать. Они задуманы не как идеализированные, а как «обыкновенные порядочные люди нового поколения», способные заниматься реальным делом. Они - «новые», потому что у них другие, чем у отизов кумиры. Они - не шеллингианцы и не гегельянцы, а материалисты и огюст-контисты. Они поклонники не искусства, а науки. У них другие, чем у отцов нравственные принципы а именно «разумный эгоизм». К «новым людям» принадлежит «передовая женщина» Вера Павловна - пионер в области новых семейных отношений и деле экономической независимости женщин. «Новые люди» заняты не спорами с отцами-ретроградами, как это было в Omцах и детях, а утверждением собственного стиля жизни, основанного на новых началах. Роман Что делать? стал культовым для молодежи 1860-х годов и во многом определил ее поведение, но вместе с тем вызвал и реакцию несогласия.

Утилитарная этика и программный агностицизм и даже атеизм поколения шестидесятников становятся объектом критики со стороны таких писателей, как Федор Достоевский, Алексей Писемский и Николай Лесков, которые трактовали нравственные основы молодого поколения иначе, чем герои Чернышевского. Достоевский изобразил в романе Записки из подполья (1864) «один из характеров протекшего недавнего времени», «одного из представителей доживающего ещё поколения» 13 , т.е., как можно догадаться, «лишнего человека». Сам герой считал себя «человеком девятнадцатого столетия» - бесхарактерным, но развитым, порядочным и страдающим. Для определения поколенческой принадлежности возраст и социальное положение героя имели второстепенное значение. Точкой соотнесения «подпольного человека» с «новыми людьми» являлись идеи, отсылающие

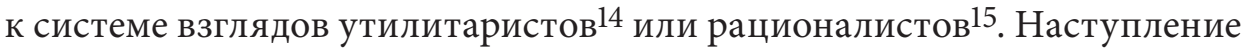
на их позиции шло со стороны отцов, которые в оценке «подпольного

12 Н.В. Володина, Кониепть, универсалии, стереотипь..., с. 49.

13 Ф.М. Достоевский, Собрание сочинений в десяти томах, т. VI, Государственное издательство Художественной литературы, Москва 1957, т. IV, с. 133.

14 В. Ермилов, Ф.М. Достоевский. Очерк творчества, [в:] Ф.М. Достоевский, Собрание сочинений в десяти..., т. I, с. 62.

15 А.П. Скафтымов, Нравственные искания русских писателей, Изд. «Художественная литература», Москва 1972, с. 109. 
человека» были более свободными, чем современное поколение, порабощенное догмами новой философии.

Принцип построения поколенческой идентичности на идейной основе остается в силе и в последующих романах Достоевского. Например, в романе Преступление и наказание (1866) поклонником «новых людей» является Лебезятников, пытающийся приобщить к их идеологии Соню Мармеладову и даже Лужина.

Петр Петрович Лужин, человек сорока пяти лет, в оценке матери Раскольникова был человеком «убеждений новейших поколений наших», т.е. причислен к новейшему поколению, но не идейной молодежи, а дельцов. Он готов был, по словам повествователя, «заискать у „молодых поколений наших"», но не чувствал общности с молодыми, наоборот, опасался новейших «мощных, всезнающих, всех презирающих и всех обличающих кружков», прогрессистов, нигилистов, обличителей.

Стиль жизни «новых людей» переняли герои романа Дым (1866) Тургенева - члены губаревского кружка - студенты-естественники, продолжавшие после закрытия Петербургского университета обучение в Гейдельберге. На это указывают рассеянные в их речах аллюзии на роман Что делать? Чернышевского. Авторское отношение к ним отражено в прозвищах «вюноши» и «дикие русские юноши» 16 . Наряду с молодежью в романе изображена высшая петербургская знать - люди поколения тридцатых-сороковых годов, на поколенческую принадлежность которых указывают определения образованные на основе цитат: пушкинских - «вся знать и моды образцы» и лермонтовских - «львы сороковых годов, «люди эпохи Героя нашего времени» 17 , использованные в качестве возрастной характеристики. Хотя обе группы не вступали в непосредственное общение, благодаря литературным реминисценциям читателю становится ясно, что шестидесятники - естественники, организаторы ассоциаций, артелей и коммун, являются оппонентами людей тридцатых-сороковых годов - русских денди и кружковых идеалистов. Отдельно от гейдельбергских студентов поставлены в романе Потугин и Литвинов. Первый выступал с позиций либерала-западника 1860-х годов, второй только стал определять свою идейную позицию. Он - предшественник постепеновцев - поколения 1880-х годов, про-

16 И.С. Тургенев, Собрание сочинений в двенадияати..., т. IV, с. 96.

17 Там же, с. 9. 
тивостоящего народническим радикалам. В изображении облика молодого и старого поколений Тургенев придавал большое значение историческим и политическим факторам, влиянию поведенческих стереотипов, сформированных на литературной основе.

Отношение к системе ценностей и стиля поведения «новых людей» Чернышевского стало важным фактором самоидентификации героев полемических романов ${ }^{18}$. По образцу тургеневского нигилиста и «новых людей» Чернышевского построен портрет молодого поколения в романах А. Писемского Взбаламученное море (1863) и Н. Лескова Некуда (1864) и На ножах (1870). Его представителями, как правило, являются студенты, названные «мальчишками», «говорунами», «семинаристами-дуботолками», которых объединяла идея разрушения и отсутствие положительной программы. Им противопоставлено поколение отцов, придерживающееся романтических идеалов.

В романе Писемского Люди сороковых годов (1869), отцы - это люди сформировавшиеся в сороковые годы. При построении модели поколения Писемский подчеркнул значение первоначального этапа интеллектуального формирования, характер чтения, воздействие литературных кумиров (Онегина и Печорина), выбор профиля образования (военного училища или университета) и университетской специальности (гуманитарной или математической), роль авторитета университетских профессоров, значение в их жизни искусства, вида службы (штатская, военная), места службы (столица, провинция). В изображении Писемского поколенческая общность возникала не на сословной основе, как это было в тургеневских романах, а на общности взглядов товарищей детства. Расхождения молодых с omцами обнаруживаются в таких вопросах как образование, служба, патриотизм. В финале романа молодые изображены повзрослевшими людьми среднего возраста, ставшими сознательными общественными деятелями, объединенными «хоровым», т.е. коллективным началом, деятелями готовыми служить реформирующейся России.

Содержащийся в романе портрет поколения вызвал критику со стороны Николая Шелгунова, публициста радикального журнала «Дело». В статье с характерным заглавием Люди сороковых и шестидесятыхх годов (1869) он

18 См.: И. Паперно, Семиотика поведения: Николай Чернышевский - человек эпохи реализма, Изд. «Новое литературное обозрение», Москва 1995. 
изложил свои взгляды на концепцию поколений не только Писемского, но и Тургенева и Гончарова. Критик согласен с самим принципом изображения - значимостью поколенческих факторов, таких как воспитание, образование, участие в студенческих кружках, но критически оценил их художественное осуществление. Шелгунов выстроил в статье поколенческую парадигму сороковых - шестидесятых годов. В поколении сороковых годов он видел «людей идеи», деятелей в области науки, литературы и философии, пионеров женского вопроса, которым чрезмерное расположение к рефлексии мешало в осуществлении поставленных задач.

Люди сороковых годов были люди чувства, их пожирала мировая любовь, их преследовали широкие идеалы, расплывающиеся стремления, они жили точно в чаду, не выяснив себе никакой точной программы общественного и частного поведения ${ }^{19}$.

В недрах этой среды образовалось поколение пятидесятников, чертой которого критик считал не политические увлечения, а активность в области семейных преобразований, стремление к нравственному раскрепощению женщин, равноправию полов в браке. В его оценке пятидесятники еще не «новые люди», а лишь «намеки на новых людей». К таковым причислены герои Накануне, но по мнению критика, не Берсенев и Шубин, а единственно Инсаров достоин звания «нового человека». «Новые» для Шелгунова - это передовые люди, каковыми он считал отрицателей в лице семинариста Проскриптского, разночинцев Базарова и Марка Волохова, с оговоркой, что идеи отрицателей еще до конца не выработаны. Принципиальное значение в присвоении звания передового поколения критик придавал делу, которому оно служило: «Дело» следует за идеей, и люди дела следуют за людьми идеи, когда она созрела и сделалась возможной для практического осуществления» 20 . «Дело» - это и было то, что определяло индивидуальный облик поколения, но его понимание вызывало споры не только между самими героями произведений, но и между писателями и авторами критических отзывов (кроме Шелгунова на эту тему высказывался Д. Писарев и др.).

19 Н.В. Шелгунов, Литературная критика, Изд. «Художественная литература», Ленинград 1974, с. 131.

20 Там же, с. 161. 
Шелгунов различал среди шестидесятников «базаровых» и «базароидов». Первым он давал положительную оценку, вторых осуждал. По представлениям Шелгунова, поколение шестидесятых годов пополняли передовые девушки, которых, в отличие от женщин предыдущего поколения, отличала не только нравственная свобода, но и забота о личной экономической независимости. Эмансипаторские устремления женщин к нравственной и материальной независимости придали образу поколения шестидесятников новые черты, отражавшие изменения в культуре и вызвали новые споры в неподготовленном к нравственным сдвигам обществе.

В споры об облике нового поколения включился и Иван Гончаров. Его, не менее Писемского и других собратьев по перу, волновал вопрос о том, каким является новое поколение. Первые две части романа Обрыв (1869) писатель отвел выяснению кто есть кто? Критерием определения являлось социальное происхождение героев (дворянское/разночинское), их возраст (старые/молодые), идейные установки (нигилисты/консерваторы).

К старому поколению по происхождению, возрасту и взглядам причислена Татьяна Бережкова - бабушка главного героя, ее друг Тит Никонович Ватутин и председатель палаты Нил Андреевич Тычков. Они олицетворяли провинциальную дворянскую культуру, которая в 1860-е годы стала объектом критики со стороны молодых наследников, пытающихся освободиться из-под оков авторитаризма предков, и со стороны интеллигентов-разночинцев, выступавших с позиций принципиальных отрицателей.

По возрастному критерию к молодому поколению принадлежат Марк Волохов, Вера и Марфинька. По идейному - только нигилист Марк Волохов, которого Шелгунов в статье Талантливая бесталанность (1869), назвал «изуродованным Базаровым» 21 и Вера, которую можно считать гончаровским вариантом «передовой женщины». В облике молодого поколения писатель запечатлел его идеологическую дифференциацию. Взгляды Волохова раскрыты в споре с Верой, которая, по замыслу автора, сочетала в себе нравственные принципы бабушки с соблюдением права на личную свободу, за которую воевали эмансипантки. Марк считал «бабушкины принципы» анахронизмом.

21 Там же, с. 244. 
Райский по возрасту принадлежал к среднему поколению (ему за тридцать лет). По взглядам он тяготел к молодежи, даже сам себя назвал «недорослем» и претендовал на лидерство в ее среде. Духовный облик Райского сформировался под влиянием романтических идеалов. Он - романтик по духу, художник, проявляющий способности в живописи, ваянии и литературе, любитель красоты, отрицатель старины в грибоедовском смысле (критикует предков - «фамусовых в юбке» и как обличитель старых норм претендует на имя Чацкого 22$)$.

Райский, - читаем в начале третьей части романа, - считал себя не новейшим, то есть не молодым, но отнюдь не отсталым человеком. [...] сам он не спешил укладывать себя всего в какое-нибудь, едва обозначившееся десятилетие, дешево отрекаясь и от завещанных историею, добытых наукой, и еще более от выработанных собственной жизнию убеждений, наблюдений и опытов, ввиду едва занявшейся зари quasi-новых идей, более или менее блестящих или остроумных гипотез, на которые бросается жадная юность 23 .

Герой скучает и самоопределяется, т.е. постоянно ищет поприще, к которому стоило бы приложить силы. Он интересуется вопросами социального устройства и, хотя открыто признается, что не силен в политической экономии, однако способен оценить хозяйственные таланты бабушки и Ивана Тушина.

По возрастному критерию к среднему поколению причислен Иван Тушин. По системе исповедуемых ценностей он примыкал к старому поколению, но по умению приспособиться к новым пореформенным порядкам мыслился автором образцовым представителем «нового поколения», каким представлял себе это поколение сам Гончаров.

После появления романа на страницах журналов возникла дискуссия о молодом поколении, в которой приняли участие писатели, публицисты и литературные критики ${ }^{24}$. Разногласия вокруг представлений о молодом

22 И.А. Гончаров, Собрание сочинений в восьми томах, т. V, Изд. «Художественная лигература», Москва 1979, с. 31.

23 Там же, с. 7.

24 См.: М.Е. Салтыков-Щедрин Уличная философия (1869), Н.В. Шелгунов Талантливая бесталанность (1869), А.М. Скабичевский Старая правда (1869), М.К. Цебрикова Псевдоновая героиня (1870), Е.И. Утин Литературные споры 
передовом поколении и его представителях заставили Гончарова написать Предисловие кроману «Обрыь» (1869), вступление к первому отдельному изданию романа Намерения, идеи и задачи романа „Обрыв” (1872) и затронуть вопрос в статье Лучше поздно, чем никогда (1879). Напряженность дискуссии, радикальность взглядов ее участников свидетельствуют о первостепенном значении обсуждаемого ими вопроса.

Для формирования представления писателей об облике поколения 186070-х годов имели значение следующие факторы: исторические (экономические и политические реформы Александра II, деятельность народнической организации «Земля и воля») и культурные (влияние журналов на умонастроения разночинской интеллигенции).

Немаловажное значение для характера душевного склада поколения семидесятников имел призыв народнических публицистов служить народу, само движение «хождения в народ», его крах и последствия. В этом поколении важную группу составляли дворяне, ищущие себе новое место в пореформенной действительности, чиновники-бюрократы и интеллигенция естественнонаучного и технического профиля образования. Все они претендовали на звание передовой силы, способной предопределить направление развития России.

Идейную неоднородность поколения представил Тургенев в романе Новь (1877). В нем находим полный поколенческий перечень: поколение молодых радикалов, представленное Неждановым, Маркеловым, Паклиным, нигилисткой Машуриной, эмансипанткой Марианной и примыкающим к ним по возрасту, но отличающимся в идейном плане постепеновцем Соломиным. Среднее поколение представлено в лице помещика-либерала Сипягина и бюрократа Калломейцева.

Достоевский также отметил обострение поколенческих конфликтов в 1870-е годы. Роман Бесы (1871) основан на конфликте отцов и детей и столкновении соответствующих культурных кодов: дворянского и радикально-демократического. Отцы - представители поколения либеральных западников сороковых годов, которые в условиях семидесятых годов стараются не отставать от молодых, перенимают стиль их поведения, заискивают перед ними. Дети - представители шестидесятых годов, базирующиеся

нашего времени (1870), В.Г. Короленко И.А. Гончаров и „молодое поколение” (1912). 
на комплексе нигилистических базаровских идей и увлечении политической кружковщиной. В отличие от отцьов, готовых с ними мириться, дети отклоняют любую форму сближения. Назревает разрыв поколений. Отиьь становятся объектом манипуляции детей и их жертвой, на что указывают слова эпиграфа к роману: «В поле бес нас водит видно». Поколенческое негодование возникает в среде оти,ов. Степан Трофимович - человек сороковых годов признался в том, что потерялся в действительности рубежа шестого и седьмого десятилетий: «Мы вовсе, вовсе не к тому стремились; я ничего не понимаю. Я перестал понимать» 25 . Ни отцьь, ни дети не хотят поступиться принципами. Диалог поколений невозможен, и поколенческий разрыв становится фактом.

Проблематика разрыва поколений продолжена писателем в Братьях Карамазовых (1881) - очередном романе об отиах и детях. В Дневнике писателя за 1876 год писатель планировал написать роман об отцах и детях и уделить особое внимание детям. В романе создан обобщенный, но неоднородный образ поколений семидесятых-восьмидесятых годов. Старое поколение в романе представляет Федор Павлович Карамазов - человек двух эпох: до и после отмены крепостного права, циничный и безнравственный крепостник и предприниматель. Портрет старого поколения дополняют госпожа Хохлакова, купец Ляговой, а также Петр Миусов - либерал 184050-х годов, русский европеец, хвастающийся личным знакомством с Прудоном и Бакуниным. Старшему поколению противопоставлено молодое поколение, главной чертой которого являлась разобщенность, т.е. отсутствие общих норм и идеалов. Представителями молодых являются Иван, сочувствующий европейскому социализму и идеалам поколения прогрессистов шестидесятых годов, Ракитин - «новый человек», утилитарист увлекающийся наукой и Алеша - истинный христианин.

Новой составляющей модели является прогноз будущего поколения, которое олицетворено в мальчиках-гимназистах. Обратим внимание, что их характеристике отведена в романе отдельная глава Мальчики. Поиски мальчиками идеала приобретают особое значение в контексте воздействия на молодежь ложных учителей в лице Ракитина - популяризатора нигилистических идей, атеизма, естествознания и социализ-

25 Ф.М. Достоевский, Собрание сочинений в десяти..., т. VII, с. 229. 
ма. Симпатии мальчиков достаются Алеше, в котором они усматривали нового учителя в будущем.

Важным фактором формирования облика очередного поколения восьмидесятников - «детей реформ» - стали исторические факты: убийство террористами Александра II и последовавшее за ним: политические репрессии, возникновение марксистской организации «Освобождение труда», оскудение гражданских идеалов, и культурные факторы, такие как изменение отношения к литературе, с которой снимаются утилитарные задачи. Николай Минский в статье Старинный спор (1884) призывал писателей уйти от реальной действительности в мир субъективной фантазии, к «вечному чистому», перейти от гражданской рефлексии к «мистическому переживанию».

Ментальный облик поколения «детей реформ» формировался под влиянием разных идейных и философских течений, таких как социалдарвинизм, плехановский марксизм, либеральное народничество, постепеновство. Большое значение имели религиозно-философские трактаты Льва Толстого, которые породили в недрах интеллигенции движение толстовства. Меняются философские основы мироздания: критически осмысленный Владимиром Соловьевым позитивизм уступил место идеализму. Немаловажное значение для поколения восьмидесятников имело возрождение религиозного сознания, начавшееся с появления первых философских трудов Владимира Соловьева, лично испытавшего разочарование в материализме и атеизме, которыми он увлекался в шестидесятые годы.

Для поколения восьмидесятников были значимы также экономические факторы. В романе Китай-город Петра Боборыкина (1882) изображено пореформенное поколение, составленное из обедневших дворян, дельцов из среды «старых западников», защитников «русских устоев» и дельцов-разночинцев. Все они расходятся во мнениях на тему деловых принципов и представлений о русском пути развития. Они спорят о поведенческих принципах личности в новой экономической реальности. В изображении Боборыкина сословный статус уступил место статусу материальному, что дало основание Иванову-Разумнику назвать поколение восьмидесятников «общественным мещанством» 26 .

26 Р.В. Иванов-Разумник, Индивидуализм и мещанство в русской литературе и жизни ХІХ века, т. II, The Hague: Mouton 1969, с. 317. 
Восьмидесятые годы ощущались русскими писателями как «время неопределенности». Вновь прозвучал старый вопрос «Такчто же нам делать?», на этот раз поставленный Львом Толстым. Образы представителей этого поколения - народовольцев, дельцов, толстовцев мы найдем на страницах массовой беллетристики и произведений Антона Чехова, а также в семейной хронике Отчий дом Евгения Чирикова, продолжавшей традиции семейного романа об обитателях «дворянских гнезд».

В Безотизовине (1878) Антона Чехова - пьесе, которую можно причислить к произведениям об отиах и детяx, у «заходящего» и «восходящего» поколений различное отношение к жизни. Глагольев 1 ссылался на духовную общность с романтиками в отношении к любви, дружбе, искусству и упрекал молодых в том, что они «изгнали романтизм». Иван Иванович Трилецкий признавался в родстве с шестидесятниками - базаровыми, и в симпатиях к материалистам и атеистам. Главным событием для своего поколения он считал русско-турецкую войну. Молодые в лицах Платонова, Софьи, Глагольева II, и Исаака Абрамовича питали враждебные чувства к отияам. Платонов считал отц,ов не романтиками, а людьми отсталыми, поклонниками фонвизинских Стародумов и Милонов, Скотинных и Простаковых. Он не любил и не уважал ни своего отца, ни его друзей.

Дети отказались от наследия оти,ов, но у них не оказалось своих идеалов. Они неспособны добросовестно работать, найти себя в сфере «интеллигентных» профессий и в результате становились «лишними людьми» или декадентами.

В повести Дуэль (1891), написанной в начале девяностых годов, но отразившей проблемы восьмидесятников, изображены наследники двух поколений: «лишних людей» (Лаевский) и сциентистов (Фон Корен). Вновь появляется традиционная для русской культуры оппозиция людей сороковых и шестидесятых годов. Духовными отцзами Лаевского - «отцами по плоти и духу», названы романтики Онегин и Печорин, байроновский Каин. Сам Лаевский считал себя «лишним» человеком, но и неврастеником восьмидесятых годов. Фон Корен - зоолог-исследователь, поклонник Спенсера и Дарвина, принципиальный враг романтиков и «лишних людей», являлся типом человека шестидесятых годов, присвоившего принципы социал-дарвинизма. Финальное примирение Лаевского с Фон Кореном не равнозначно сближению поколений. 
В хронике Отчий дом Чирикова, охватившей более чем 25-летнюю историю России, представлена история дворянской семьи - матери и ее троих сыновей и внуков. Родовой критерий как основание общности оказался не действенным. Рожденные в пределах одного десятилетия, братья существенно отличались друг от друга. Старший - либеральный «передовой земец», впоследствии - политик, средний - радикальный народоволец и заодно жертва новых революционеров, младший - последователь христианского социализма. Их объединяет отталкивание от идеалов отца «помеси крепостника с вольтерианцем» и матери - хранительницы дворянских устоев, и следование духу времени, в котором обращает внимание усиление политических разделов.

Девяностые годы - время политической борьбы сторонников экономических реформ министра финансов Сергея Витте с придворной камарильей Николая II, возглавляемой Вячеславом Плеве, будущим министром внутренних дел. Политическая борьба способствовала идейному делению в пределах одного поколения.

Жизненные позиции поколения девяностых годов складывались под влиянием разных идейных течений. Наряду с идейной интеллигенцией, которая жила злобой дня, появилась интеллигенция программно аполитичная. Она углубилась в самоанализ, погрузилась в созерцание искусства. Точкой соотнесения поколения детей, изображенных Чеховым в повести Моя жизнь (1896), оставались идеи шестидесятников, но немаловажное значение имели толстовские идеи опрощения. В повести вновь появляется тема отиов и детей. Отец и сын Полозневы находятся в состоянии личной вражды и являются идейными антагонистами. Сын пытается освободиться от наследия отца - дворянина по происхождению, но «чиновника по духу». Молодое поколение (Мисаил и его сестра, доктор Благово, Маша Должикова) изображено на этапе поисков жизненного пути. Мисаил выбирает путь опрощения, доктор Благово - науку, Маша Должикова - искусство. Они - «поколение на распутье».

Процесс деления в пределах одного поколения усилился в первое десятилетие XX века, когда появились многочисленные партии, такие как Партия социалистов-революционеров, Конституционно-демократическая партия, Русское собрание, Объединенное дворянство, Российская социал-демократическая рабочая партия и др. Факты политической жизни имели принципиальное значение для идейного размежевания столичной 
и провинциальной интеллигенции - героев хроники Чирикова, на дальнейшее деление общества не на возрастной, а на политической основе.

Молодое поколение рубежа XIX и XX веков отличает духовная раздвоенность. С одной стороны, оно испытывает разобщенность с отизами, с другой - связь с ними. Основой состояния, ощущаемого молодьми как препятствие к сближению с отияами, является нелюбовь к науке, которой жило предыдущее поколение и увлечение искусством, которым пренебрегали отиьь. Сложность поколенческих дилемм особо заметна у «профессорских детей», т.е. русских символистов. В их высказываниях появляется осознание собственной «особости», понимание себя как литературного поколения, отличающегося от поколения ученых ${ }^{27}$. Например, Андрей Белый иронизировал над либерализмом отцьов с их призывами к гуманности и верой в конституцию, с их идеалом поступать «конституционно и позитивистически», но признавался в близости с ними ${ }^{28}$. В то же время в романе Петербург, подключающим литературный контекст Отцов и детей Тургенева, им созданы образы представителей двух поколений: отца - крупного чиновника и сына - почитателя Канта и несостоявшегося террориста. Героев связывает сложное чувство любви-ненависти. Отец недоволен сыном, сын - отцом. Оба называют друг друга негодяями и совершают символический акт убийства. В финале романа состоялось своеобразное примирение сторон: отец поселился в деревне и стал писать мемуары, сын погрузился в чтение философа Сковороды. Коллективный портрет молодежи, с которой общался сын получился гротескным, представляющим собою коллекцию масок. Молодые названы «куклами», «бранкуканами», «мокрицами», т.е. они - миражное поколение.

Итак, модель поколения в русской классической литературе строилась не на биологической, но на исторической и социокультурной основе. На протяжении века русские писатели создавали модели поколения, которые трансформировались под влиянием исторических событий, таких как отечественная война с Наполеоном, восстание декабристов, реформы Алек-

27 Определение «профессорские дети» появляется в мемуарах А. Белого На рубеже двух столетий (1926).«Отцы» - это наследники так называемой «профессорской культуры».

28 См.: B. Olaszek, «Профессорские дети» в отношении к позитивизму и символизмy, [w:] Dialog idei i poetyk, red. O. Główko, PRIMUM VERBUM, Łódź 2008, s. 213-223. 
сандра II, убийство царя, идеологических влияний славянофилов, западников, народников в их радикальном и либеральном вариантах, наконец, марксистов. Писатели «мыслили поколениями». Поколения отделяло друг от друга двадцатилетие. На протяжении девятнадцатого века наиболее выразительными были поколения двадцатых, сороковых, шестидесятых, восьмидесятых и девятисотых годов. Основным типом межпоколенческих отношений была полемика.

Поколение 1820-х годов отталкивалось от просветительских традиций екатерининского века, утверждало идеалы индивидуализма. Для поколения 1840-х годов романтические идеалы оказались неосуществимыми, что отражено в концепте «лишние люди». Очередное поколение 1860-х годов формировалось в оппозиции к системе ценностей поколения «лишних людей» и претендовавало на звание прогрессивного поколения. Напряжение между этими поколениями лучше всего отражает концепт отцы и дети. Идентификация очередных генераций проходила путем отношения к системе ценностей отцов 1840-х и детей 1860-х годов. Поколение 1880-х годов - «детей реформ» пыталось освободиться от влияния обеих традиций, и сороковых, и шестидесятых годов, но не предложило собственных идей и может быть названо «поколением на распутье». Молодое поколение рубежа ХІХ и XX веков испытало трудности в самоидентификации. Оно одновременоо отталкивалось от культурного наследия отцов и воспринимало его.

Межпоколенческая коммуникация держалась на опозиции к предшественникам и существовала в виде неутихавшего спора, что дает основание для выдвижения тезиса об агональном характере русской культуры, который мы постараемся обосновать в ходе дальнейшего исследования.

В контексте сложившегося представления о главных участниках русского агона особый интерес вызывают причины и предмет поколенческих споров. Заранее отметим, что поколенческие различия не были единственным механизмом порождения споров. Споры возникали и между представителями одного поколения и вызывались разными причинами, идейными и политическими, которые будут рассмотрены в главе, посвященной содержанию «русских споров» у классиков. 



\section{Глава IV}

\section{Споры о принципах}

\section{IV.1. Спор в комедии Грибоедова Горе от ума}

В русской культуре правила и нормы поведения личности являлись необыкновенно важными. Поэтому часто возникали споры вокруг системы ценностей и поведенческих принципов личности. Споры на эти темы имели аксиологический характер.

Александр Грибоедов в комедии Горе от ума поставил героя, вернувшегося из продолжительного заграничного путешествия «за разумом», в ситуацию столкновения с московскими фамусовыми, продолжавшими жить по представлениям людей екатеринских времен. Чацкий и Фамусов как представители двух поколений вступили в спор о принципах поведения молодежи в современных условиях. Спорным оказался вопрос о карьере, о понимании службы и отказе «прислуживаться», о верности принципам.

Чацкий решительно отклонил образец службы, указанный ему Фамусовым в качестве примера для подражания, определив его прислуживанием. Молодой человек выше всего ценил личную свободу. Поискам покровительства герой противопоставил просветительский путь карьеры - занятия наукой, заграничное путешествие «за разумом», использование опыта путешествий в «службе делу». Фамусов само обсуждение этих вопросов даже в рамках беседы считал проявлением вольнодумства со стороны молодого человека, причину которого он усматривал во влиянии Запада:

Вот рыскают по свету, бьют баклуши,

Воротятся, от них порядка ждиํ․

1 А. С. Грибоедов, Горе от ума, Изд. Детская литература, Москва 1969, с. 32. 
Фамусов несколько раз пытался помешать Чацкому в изложении аргументов в поддержку тезиса о необходимости обновления русских нравов, неоднократно просил его молчать и не спорить с важными лицами. Критический потенциал Чацкого дополнительно нашел противодействие в светской московской среде, повторявшей сплетню о его сумасшествии и затем исключившей его из своих рядов. Пушкин, считавший Горе от ума картиной нравов эпохи, оценил спор Чацкого с московским обществом как бессмысленный и недостойный умного человека. По его мнению: «Первый признак умного человека с первого взгляду знать с кем имеешь дело, и не метать бисера перед Репетиловыми и тому под.»². Герой действуя под влиянием эмоций, отступил от дальнейших прений с противниками и решился покинуть Москву. Тем самым он обрек себя на скитальничество. Чацкий по мнению Николая Бердяева являлся предшественником характерного для России типа странника, в котором философ видел воплощение русского интеллигента ${ }^{3}$. Другое мнение о Чацком у Юрия Лотмана. Ученый доценил независимость и отвагу Чацкого высказывать и отстаивать свои мнения и увидел в нем исторический и психологический тип декабриста ${ }^{4}$. Думается, что каждый из ученых прав по-своему. Чацкий был человеком сформированным в культуре просвещения, у которого была цель, и которого можно назвать предшественником декабристов, стремившихся к преобразованию страны в конституционную монархию. Одновременно он был чрезмерно эмоционален, неспособен к компромиссу и постепенному осуществлению планов. В этом смысле он был романтиком. В культуре романтической эпохи ценились оригинальность и неподчинение принципам. Такими чертами обладали Онегин и Печорин. Они отделывались иронией от пошлости окружающей действительности, не снижаясь к спору с глупцами. Для Онегина спор являлся видом светского развлечения и имел фатический характер. Печорин также не стремился к спорам, а либо отделывался молчанием, либо в ответ на упреки в свой адрес уходил в иронию. Романтические герои не спорили о принципах. Они их отклоняли.

2 А.С. Пушкин, Собрание сочинений в десяти томах, т. IX, Изд. «Художественная литература», Москва 1977, с. 127.

3 См.: Н. Бердяев, Судьба России, Изд. МГУ, Москва 1990, с. 12.

4 Ю.М. Лотман, Декабрист в повседневной жизни. (Бытовое поведение как историко-психологическая категория), [в:] Литературное наследие декабристов, Изд. «Наука», Ленинград 1975, с. 27. 


\section{IV.2. Споры в монологическом романе}

Позиция авторов в борьбе за принципы довольно отчетливо отмечена в монологическом романе, который характеризуется «включенностью сознаний всех персонажей, каков бы ни был их кругозор и уровень самосознания, в объемляющую перспективу («оправу», по Бахтину) авторского видения» 5 . Подчиненность кругозоров героев авторскому сознанию может означать, что в данном типе романа цель спора состояла не только в выработке принципов, но и укреплении в сознании читателей той истины, которой автор дорожил. Такая необходимость появлялась в переломное время, например, в сороковые годы - время трансформации романтической системы ценностей с их культом свободы, дружбы и искусства, в прагматическую систему ценностей эпохи реализма, основанную на практике, опыте и науке.

Смена системы ценностей отчетливо отмечена Иваном Гончаровым в романе Обыкновенная история, основанном на диалоге-споре поколений. Главными его участниками выступили Петр Адуев - человек среднего возраста, прагматик и его двадцатилетний племянник Александр - идеалист-романтик. «Диалоги героев напоминают споры каждого с самим собой на иной (предшествующей-последующей) стадии жизни»считает Елена Краснощекова ${ }^{6}$. Сюжет романа «движим столкновением „взглядов на жизнь” Адуева младшего и старшего как двух человеческих философий жизни, испытанных в процессе диалогического конфликта» 7 . В нашем представлении самое существенное значение в романе имеют не только внутренние, но и возрастные споры героев на тему отношения к службе, искусству, дружбе, любви и браку. Разногласия на эти темы обнаружились в сюжетной ситуации появления племянника, свежеиспеченного выпускника университета в доме дяди - столичного делового человека. Александр, обремененный культурным багажом выходца идиллической усадьбы, не одобрил принципов столичной действительности,

5 Поэтика: словарь актуальных терминов и понятий, ред. Н.Д. Тамарченко, Изд. Intrada., Москва 2008, с.129.

6 Е. Краснощекова, И.А. Гончаров. Мир творчества, «Пушкинский фонд», Санкт-Петербург 1997, с. 68.

7 В.А. Недзвецкий, И.А. Гончаров - романист и художник, Изд. МГУ, Москва 1992, с. 29. 
что, по словам повествователя, предсказывало принципиальный спор: «Провинциальный эгоизм его объявляет войну всему, что он видит здесь и чего не видел у себя» 8 .

Свою систему ценностей герой противопоставил чужой системе. Олицетворением чужого мира стал для провинциального племянника столичный родственник, успешный человек. Несмотря на отсутствие эксплицитно заявленного предмета спора (отсутствие четкого тезиса), герои постоянно высказывали противоположные мнения и стремились убедить друг друга в своей правоте. Причем дядя выступал в роли ментора, а племянник - ученика, который ему робко возражал. Предметом разногласия стало объяснение понятия жизнь, которое герои понимали по-разному: Александр в высоком смысле образа существования, Петр в сниженном установившегося порядка повседневной жизни. Дядя заставлял племянника конкретизировать представления о жизни, которую тот понимал романтически как деятельность во имя благородных целей, как высокие стремления, осуществление надежд. Он тут же оспоривал его положения. Романтическому пониманию жизни он противопоставил прагматическое ее понимание. Петр Адуев приклеил племяннику ярлык провинциала и оценил его систему ценностей - идеальную любовь, верную дружбу, счастье и прелести жизни на натуре как устаревшую. Сам он предпочитал мечтам целевую деятельность, направленную на карьеру и успех и последовательно убеждал племянника в необходимости в корне изменить представления о жизни.

Одной из тем спора стало гостеприимство, которое Петр Адуев считал не признаком радушия и хлебосольства, а желанием развлечься, внести разнообразие в будничную жизнь. Итогом прений стало заключение Петра Ивановича, однозначно определившее жизненные установки участников: «совершенные антиподы!». Затем предмет спора был расширен на взгляды сторон на дружбу и любовь. Базовые понятия, составляющие жизненный кодекс племянника-романтика, были осмеяны дядей-прагматиком. Аргументы в споре изложены в форме инвариантных писем, адресованных другу Александра. Автором первого письма являлся он сам, второго - дядя.

8 И.А. Гончаров, Собрание сочинений в восьми томах, т. I, Изд. «Художественная лигература», Москва 1979, с. 66. 
Первое являлось своеобразным списком тезисов, второе - их переосмыслением в форме контраргументов.

По ходу «взросления» Александра стали меняться его взгляды на спорные вопросы. Система ценностей «делового века», основанная на разуме, причинности, опыте, которую последовательно утверждал дядя, постепенно признается племянником объективной реальностью, с которой бессмысленно спорить. Однако одобрение прагматических ценностей вызвало у него депрессивное состояние, что отражают слова: «я воспитанник вашей школы, а между тем мне скучно жить...». Наставник, желая окончательно убедить юного родственника в своей правоте, прибегал к обобщениям, ссылаясь на пример современной молодежи:

Посмотри-ка на нынешнюю молодежь: что за молодцы! Как все кипит умственной деятельностью, энергией, как ловко и легко управляются они со всем этим вздором, что на вашем языке называется треволнениями, страданиями...9

В финале романа племянник, к этому времени человек уже среднего возраста, согласился с дядей в вопросах, которые волновали его в начале жизненного пути, но произошло это не столько под влиянием аргументов, предъявленных в споре, сколько в результате личного опыта и убежденности в необходимости приспособления к условиям «железного века».

Беседам героев на спорные темы сопутствовали сильные эмоции. Александр «обращался к дяде с испугом», «приходил в ужас и отчаяние», «впадал в бешенство», а дяде «было досадно, что он стал объяснять то, что считал общеизвестной истиной».

Спор о принципах поведения продолжен писателем в романе Обломов. Обломов по своему темпераменту не был расположен к спору, так как усматривал в нем источник лишних волнений, которых старался избегать.

В первой части романа изображен ряд ситуаций общения Обломова с товарищами, которые посещают его с намерением уговорить участвовать в весенней прогулке. Между ними и Обломовым шел невербализованный спор (во время визитов Обломов предпочитал дремать и слушать) о преимуществе определенного образа жизни: инерции - производной

9 Там же, с. 288. 
«философии умного лентяя» и активности - жизненной установке делового человека. В итоге Обломов остался при своем мнении.

Принципиальное значение для выяснения жизненных установок Обломова имели его споры со Штольцем. Инициатива принадлежала в них Штольцу, человеку мобильному, способному быстро перемещаться с места на место, ориентироваться в меняющейся обстановке. Он желал «расшевелить» друга, ведущего неподвижный образ жизни, и постоянно придумывал «чем бы задеть его за живое и где у него живое», т.е. спровоцировать к спору.

Темой споров друзей стало понимание жизни. Лексема жизнь приобрела в их разговоре статус ключевого слова (оно повторяется, употребляется в анафорической позиции). Основная причина расхождения взглядов на жизнь обоих друзей коренилась в неодобрении Обломовым динамических темпов петербургской жизни: «Не нравится мне эта ваша петербургская жизнь!» [...] «Я не хочу ее»10. Данные высказывания можно принять за исходный тезис спора со Штольцем, увлеченным темпами современной жизни. Обломов использовал в качестве аргументов ряд развернутых характеристик, содержащих критическое осмысление петербургской жизни и неодобрение способов делать карьеру. Они завершены философским вопросом героя: «Где же тут человек? Где его целость?» Штольц противопоставил аргументам Обломова замечание о несвоевременности мыслей Обломова: «- Ты рассуждаешь, точно древний: в старых книгах вот так все писали» ${ }^{11}$ и требование к другу предоставить факты, которые служили бы подтверждением преимуществ усадебной жизни. Дальнейший ход разговора показал, что Обломов считал благом неподвижный идиллический образ жизни. Он принимал желания за факты, что снижало силу его аргументов. Предпочитаемый Обломовым идеал идиллической жизни вызвал у Штольца вопрос-возражение о смысле технического и экономического прогресca, в необходимости которого, в отличие от Обломова, он не сомневался. Штольц в качестве контраргумента припомнил слова и мысли друга, произнесенные им в молодости: «служить, пока станет сил, потому что России нужны руки и головы для разрабатывания неистощимых источников...»12.

\footnotetext{
10 Там же, т. IV, с. 176-177.

11 Там же, с. 177.

12 Там же, с. 184.
} 
В ответ Обломов, исходя из перспективы человека зрелого возраста, назвал идеалы молодости «глупостью». Для обоснования настоящей жизненной позиции он сослался на черты человеческой натуры, но обосновал их не логическими, а психологическими аргументами. Его реплики имеют вид исповеди. Штольц, несмотря на деловой характер предъявляемых аргументов, не сумел убедить Обломова в пагубности идиллической мечты и лени как желаемого им идеала современного человека. Спор разрешился не на вербальном, а на событийном уровне. Обломов расстался с Ольгой и нашел идеал идиллической жизни в браке с мещанкой Пшенициной. Штольц, не нарушив нравственных принципов общения с окружающими людьми, достиг успеха и в личной, и в деловой жизни.

Параллельно с Гончаровым об облике героя времени и принципах его поведения писал Иван Тургенев, начиная с романа Рудин и заканчивая романом Новъ. Автор ставил героев в ситуации располагавшие к изложению и защите мнений. Сюжетная схема таких ситуаций содержит элемент перемещения персонажей в пространстве и связана с приездом/появлением нового лица, образовавшем новую сюжетную и коммуникативную ситуацию. Новое лицо нарушало устоявшуюся в данной среде систему взглядов, давало толчок к спору, становилось оппонентом тех, чьи взгляды были строго определены.

В романе Рудин будничную обстановку дома Дарьи Ласунской нарушил приезд господина, прибывшего заменить модного докладчика в изложении статьи по политэкономии. При первом появлении в салоне Ласунской он оказался в оппозиции с его завсегдатаями. Противником Рудина, выпускника Московского университета, слушавшего курсы в университетах Берлина и Гейдельберга, стал Пигасов - выпускник Дерптского университета. Настоящим предлогом спора послужило не содержание статьи барона, а его методология, как бы мы этот предмет определили сегодня. Пигасов упрекнул автора статьи Муффеля и его заместителя Рудина в пристрастии к общим рассуждениям. Он принципиально отрицал смысл общих рассуждений, обозрений, заключений, систем, противопоставив им значение фактов и опыта и требовал предъявления в споре логических опровержений и доказательств:

... я три года в Дерпте выжил... все эти так называемые общие рассуждения, гипотезы там, системы... извините меня, я провинциал, правду-матку 
режу прямо... никуда не годятся. Это все одно умствование - этим только людей морочат. Передавайте, господа, факты, и будет с вас 13 .

В своих возражениях Рудин держался общих положений, фактам противопоставлял их смысл. В споре он прибегал к риторическим уловкам, таким как умышленное обобщение, подмена предмета спора, упрек в противоречии и, в результате, победил противника своим диалектическим искусством. Рудин, как опытный спорщик, перевел спор из-за тезиса, которым была необходимость методологических установок, на противоречия аргументации Пигасова и, таким образом, одержал победу над ним перед собравшейся в салоне публикой. Подавленный напором слов Пигасов «отошел в сторону», т.е. прекратил спор. Дарья Михайловна, выступившая в роли своеобразного арбитра, назвала реакцию Пигасова «бегством».

Он никого из нас не обманул. Он желает показать вид, что не хочет больше спорить... Он чувствует, что не может спорить с вами 14 .

Последнее заключение: «не может», не равнозначно окончанию спора, который продолжен в других ситуациях.

Рудин в последовавших длинных монологах затрагивал общефилософские темы, такие как самолюбие, истина и говорил о них с пафосом. Пигасов снижал высокие темы, иронически убеждая, что легче жить без истины, чем без хорошего повара. Хотя Дарья Михайловна «поняла мало из всего, что говорил Рудин», она признала его преимущество перед Пигасовым. Ее приговор напоминает оценку, которую в свое время Лежнев дал Рудину, соревновавшемуся с Покорским. Это свидетельствует о том, что спор Пигасова с Рудиным воспринимался как состязание за первенство перед собравшимся обществом и что победила в нем не сила аргументов, а риторическое искусство Рудина. Цельную оценку риторического искусства Рудина дал повествователь: «В спорах он редко давал высказаться своему противнику и подавлял его своей стремительной и страстной аналитикой» 15 .

13 И.С.Тургенев, Собрание сочинений в двенадияати томах, т. II, Государственное издательство Художественной литературы, Москва 1954, с. 30.

14 Там же, с. 34.

15 Там же, с. 42. 
Вопреки заключению, что спор между Пигасовым и Рудиным имел характер эристический (он проходил перед собравшимся в салоне обществом, на глазах у молодежи, ищущей своего кумира), следует подчеркнуть его значение как знака времени, подмеченного Тургеневым. Имеется в виду смена философской парадигмы научной парадигмой, когда гегелевскую диалектику постепенно вытеснял позитивизм как научная философия, а риторическое искусство осмысления действительности отступало перед логическим, основанным на фактах способом ее описания 16 .

Несмотря на несостоятельность Рудина в жизни и на практическом поприще, автор романа защищал его от осуждения. Оценка Рудина становится предметом спора, главными участниками которого выступили Пигасов, Лежнев и Басистов. Пигасов по-прежнему порицал Рудина, Лежнев с Басистовым защищали последнего, подчеркивая его историческую роль. Лежнев парировал ключевой аргумент Пигасова об опасности для России риторического слова, отождествляемого с философией, подчеркивая превосходство рудинского «энтузиазма» над «рассудительностью» современного поколения.

Философские хитросплетения и бредни никогда не привьются к русскому: на это у него слишком много здравого смысла; но нельзя не допустить, чтобы под именем философии нападали на всякое честное стремление к истине и к сознанию17.

Лежнев не осудил Рудина, а напротив, увидел в нем трагическую личность. Он не убедил Пигасова, который в ответ на реплику приписал Лежневу рудинское красноречие - признак отрицательной характеристики. Спор формально завершился переменой темы, но нашел продолжение в «камерном» обмене мнениями Лежнева с женой, объектом которого стал Пигасов. Он назван Лежневым не только порицателем философии, прав женщин, но и взяточником. Завершающая отрицательная характеристика Пигасова отражает позицию автора романа в отношении к участникам спора.

16 См.: Б. Оляшек, Русский позитивизм. Идеи в зеркале литературы, Wyd. Uniwersytetu Łódzkiego, Łódź 2005, s. 31-32.

17 И.С. Тургенев, Собрание сочинений в двенадиати..., т. II, с. 118. 
К спорам о принципах можно причислить спор героев романа Дворянское гнездо Михалевича с Лаврецким. Михалевич как субъект спора в качестве жизненного credo выдвинул добро и истину - универсальные идеалы, которых придерживалось поколение тридцатых годов. Пафос, с которым он излагал свои взгляды, вызвал негодование и возражение со стороны Лаврецкого. Ключевое значение в возникшем споре имело оперирование отвлеченными понятиями. Оба спорщика «цеплялись за слова и возражая одними словами, заспорили они о предметах самых отвлеченных», таких как разочарование, скептицизм, любовь, судьба.

Пристрастие к риторическому искусству - черта людей тридцатых годов, признана сторонами спора неподходящей для духа пятидесятых годов, требовавших не слов, но деятельного участия в общественной жизни. Исходя из этих позиций, Михалевич, следуя духу Белинского, упрекнул Лаврецкого в пассивности и назвав его «байбаком», призвал заняться делом ${ }^{18}$. В очередных репликах он сделал объектом критики не только Лаврецкого, а целое поколение:

- И когда же, где же люди вздумали обайбачиться? [...] - у нас! теперь! в России! Когда на каждой отдельной личности лежит долг, ответственность великая перед богом, перед народом, перед самим собою! Мы спим, а время уходит; мы спим... ${ }^{19}$.

Призыв Михалевича откликнуться на «разумную действительность»не принес желаемого эффекта. Лаврецкий отнес слова друга «мы спим», содержащие суть общественного диагноза к конкретной ситуации их ночного общения, придав им иронически-комический характер: «мы вовсе не спим теперь, а скорее другим не даем спать». Тем самым он снизил общественное звучание реплики. Спор прекратился, а его участники легли спать. Наставления Михалевича не повлияли на поведение Лаврецкого, но позволили по контрасту с бывшим товарищем, продолжавшим жить идеалами («не унывал и жил себе циником, идеалистом, поэтом»), осознать личную несвоевременность. Спор не принес ответа на вопрос «как жить?». Лаврец-

18 См.: В. Щукин, Русское западничество. Генезис - сущность, историческая роль, Ibidem, Łódź 2001, с. 102.

19 И.С.Тургенев, Собрание сочинений в двенадиати..., т. II, с. 218. 
кий - человек «рудинского склада», духовный облик которого сформировался в тридцатые годы в кружке Станкевича, в сороковые годы проявил черты «лишнего человека». С такими людьми будут спорить о принципах представители очередного поколения. Споры «лишних людей» с разночинцами-отрицателями писатель изобразил в романе Omцы и детu, который стал точкой соотнесения для полемических романов и поэтому, несмотря на нарушение хронологии изложения споров из-за принципов, он будет рассмотрен в их ряду.

В романе Дьм, последовавшим за романом Отцы и дети, принципы названы убеждениями. Участвовавшая в спорах молодежь настаивала на праве иметь убеждения и отстаивать их. Участники не стремились, как это принято в споре, ведущемся по правилам, объяснить значение ключевого понятия убеждения, вокруг которого возник спор. Члены кружка Губарева заботились лишь о «чистоте убеждений», о содержании которых можно догадываться по историческому контексту. Можно предположить, что речь шла не о нравственных, а о политических убеждениях, контекстом которых были споры Тургенева с Герценом и со славянофилами ${ }^{20}$. Убеждения становились причиной ссор в среде молодежи, которым сопутствовали сильные эмоции. По ходу разговоров молодые люди рассуждали буквально обо всем, но в итоге не помнили, с кем конкретно и о чем спорили. «Да с кем же я сейчас спорил и о чем?» - спрашивал один из них. Их споры лишены четко сформулированного тезиса, а в качестве аргументов использованы сплетни. В интенции автора спор послужил не защите убеждений, а характеристике спорщиков. Присутствующий на сходке Потугин не возражал молодым радикалам и молчал в знак несогласия. Свое мнение на тему спора он высказал позже, во время визита к Литвинову. В его репликах тоже обнаружились недостатки аргументации, а именно нечеткость понятий и предрасположенность к «общим местам», таким как свобода, порядок, цивилизация, народность, патриотизм, которыми насыщен русский дискурс.

Вот чего испугались! Общее место! Я знаю много хороших общих мест. Да вот, например: свобода и порядок - известное общее место. Что ж, по-вашему, лучше, как у нас: чиноначалие и безурядица? И при том разве все эти общие фразы, от которых так много пьянеет молодых голов:

20 См.: С.М. Аюпов, И.С. Аюпов, Романы И.С. Тургенева 1860-х годов в мире контекстов, РКО РУНМЦ МО РБ, Уфа 2010, с. 140-120. 
презренная буржуазия, souverainité du peuple, право на работу, - разве они тоже не общие места? 21

Многословие Потугина, дало основание Литвинову приклеить собеседнику ярлык романтика тридцатых годов, поскольку тому, как и Рудину, свойственно было красноречие.

Генеральское общество волновали другие, чем молодежь, вопросы, прежде всего - общественное положение аристократии в новых экономических условиях, ее верность традиционным убеждениям и принципам. Участники разделены на «раздражительных» и «снисходительных». Они как сословная группа подчеркивали значение аристократических принципов, отличающих их от других сословий. Соглашаясь друг с другом в принципиальном для аристократии вопросе сохранения сословных привилегий, они подчеркивали значение верности принципам: «Порядочный человек нигде и ни в каком случае не должен отступаться от своих убеждений» 22 - утверждал «снисходительный генерал». Генерал Ратмиров затронул вопрос роли вольной печати, университетов и семинарий в борьбе за принципы и пришел к следующему заключению:

Демократия вам рада, она кадит вам, она готова служить вашим целям... да ведь это меч обоюдоострый. Уж лучше по-старому, попрежнему... верней гораздо. Не позвольте умничать черни да вверьтесь аристократии, в которой одной и есть сила...23

Он предложил не диалог, а «палочный аргумент» как способ решения политических вопросов. Остальные участники дискуссии пытались смягчить резкость суждений генерала, обратив их в шутку (одна дама заметила, что генерал говорит глупости, Ратмиров - что он преувеличивает, «снисходительный» генерал назвал приверженца палки шалуном).

Настоящим оппонентом генералов оказался Литвинов, который иронически осудил их мечты вернуться к дореформенным порядкам. Его голос сословно чужого человека был воспринят генералами с вежливым прене-

21 И.С.Тургенев, Собрание сочинений в двенадияати..., т. IV, с. 36.

22 Там же, с. 65.

23 Там же, с. 67-68. 
брежением. Их отношение к Литвинову показывает тщеславие и превозношение себя. Литвинов не только не сблизился с генеральским обществом, но убедился в полной своей отчужденности от него: «Он любил все, что они ненавидели, он ненавидел все то, что они любили» 24 .

Спор о принципах возобновился при очередной встрече Литвинова с генералами. Он проходил в форме светской беседы, участники которой затрагивали политические вопросы, но не умели изложить их сути, выслушать и понять возражения оппонентов и вместо доводов прибегали к многословию и словесной агрессии. Ход препирательств исключал возможность положительного вывода. Прения спорщиков оказались таким же пустыми как споры в среде гейдельбергской молодежи и не привели к выработке ценных руководящих принципов.

Вопрос сохранения традиционных аристократических ценностей или отказа от них оставался актуальным и в последующие десятилетия. В романе Новb, действие которого проходит в семидесятые годы, защитником сословных принципов «консерваторских, патриотических и религиозных» изображен министерский чиновник Семен Петрович Калломейцев. Русский консерватизм, отметим, базировал на патриархальном каноне 25 . В одном ряду с Калломейцевым поставлен пролиберальный помещик Сипягин. По словам повествователя, он - либерал, который «давно поставил себе правилом [...] уважать всякого рода убеждения, но только с тем [...], чтобы они удерживались в известных границах благопристойности и благоприличия» 26 . Особо осмотрительно он относился к людям, расположения которых к себе он искал.Таким человеком был для Сипягина талантливый механик и управляющий фабрикой Василий Соломин. Сипягин в роли хозяина, обладавшего высокой культурой, безуспешно стремился помешать потенциальному спору Соломина с Калломейцевым о принципах. Во время визита в доме Сипягиных Соломин вел себя свободно, «как человек, у которого и чувства и мысли несложные, хоть и крепкие». Он ценил личное достоинство, основанием которого было образование и труд, не робел перед аристократами, вел себя независимо, нарушал светский этикет, спо-

24 Там же, с. 69.

25 А.Н. Боханов, Введение, [в:] Русские консерваторы, Информационно-издательское агентство «Русский мир», Москва 1997, с. 6.

26 И.С. Тургенев, Собрание сочинений в двенади,ати..., т. IV, с. 281. 
рил по-деловому. Аристократ Калломейцев отказывал в праве на личное достоинство лицам недворянского происхождения. Он выступил защитником аристократических принципов и как иронически заметил повествователь, не допускал крестьян в свой «раздушенный европейский кабинет». Исходя из сословных позиций, он демонстративно манифестировал пренебрежение к Соломину: «внуретнно закипал», от возмущения «играл мускулами на щеках», «зажимал челюсти», «хохотал язвительно». Сипягин вел себя в беседе-споре прагматически. Он сочувствовал Калломейцеву, но по хозяйственным соображениям искал расположения Соломина - талантливого менеджера и техника. Поведение героев в споре подтверждает риторическое правило, что внешние манеры спорщика не только дополняют его вербальные высказывания, но и влияют на восприятие его аргументов. Рассматриваемая ситуация показывает, что автор романа стремился показать противоречие не отдельных положений, но культурных кодов, аристократического и разночинского.

Согласно идеологическому стереотипу главными отрицателями дворянских правил изображены в романе молодые радикалы - Нежданов, Марианна, Маркелов. По занимаемому ими положению наемных работников и нахлебников в доме Сипягина, они не могли на равных с хозяевами правах принимать участие в застольных спорах и свободно высказывать свое мнение. Оказавшись в своей компании, они стали разбирать личные недостатки и достоинства. Их спор имел личную подоплеку. Маркелов с Неждановым начали с личных упреков друг другу в измене политическим убеждениям, в предпочтении любви делу и кончили альтруистическим примирением.

Почти параллельно с Тургеневым русскую жизнь семидесятых годов осмыслил Лев Толстой в романе Анна Каренина. Круг сходных тем и вопросов получил в нем другое истолкование, чем у Тургенева. Контексты романа, его связь с духовными исканиями дворян и разночинцев, идейными течениями эпохи, тщательно исследованы Борисом Эйхенбваумом 27.

Одной из модных тем, занимавших героев романа Анна Каренина и одновременно актуальных в семидесятые годы, была философская онтология. Субъектами споров на тему философских принципов изображены

27 Б. Эйхенбаум, Лев Толстой. Семидесятые годь, «Художественная литература», Ленинград 1974. 
«известный профессор философии» из Харькова и Сергей Кознышев, ученый и порицатель материализма. Случайным участником их беседы на тему границ между психическими и физиологическими явлениями стал Левин. Толстой опирался в построении образов спорщиков на реальные прототипы и споры ${ }^{28}$. Тема их спора контекстуально связана с реальными спорами психологов и материалистов-физиологов, Константина Кавелина и Ивана Сеченова, которые проходили на страницах научных журналов этого времени ${ }^{29}$. Прислушивавшемуся к спору Левину бросилась в глаза казуистика аргументации спорщиков. В его восприятии оба, и профессор, и Кознышев:

... связывали научные вопросы с задушевными, но каждый раз, как только они подходили близко к самому главному, как ему казалось, они тотчас же поспешно отдалялись и опять углублялись в область тонких подразделений, оговорок, цитат, намеков, ссылок на авторитеты, и он с трудом понимал, о чем речь ${ }^{30}$.

Левин, желая разрешить волновавшую его мысль о смысле жизни, задал профессору вопрос о возможности загробной жизни. Профессор не счел нужным ответить ему только потому, что Левин показался ему дилетантом в философских вопросах. Повествователь критически прокомментировал реакцию профессора, указав на односторонность его ума и неспособность отвечать на простые и естественные вопросы. Дополнительно критическая оценка ученого обнаружилась в реакции Левина, который первоначально заинтересовался темой спора, но постепенно перестал вникать в смысл рассуждений профессора и перестал его слушать.

В другой ситуации, накануне венчания, Левин, которого продолжал волновать смысл бытия, исходя с позиций философии жизни, обратился к священнику и затем к своему товарищу по университету, профессору естественных наук Катавасову с просьбой разрешить его религиозные

28 Э.Г. Бабаев, Комментарии, [в:] Л.Н. Толстой, Собрание сочинений в двадияmи двух томах, т. VIII, Изд. "Художественная литература», Москва 1980, c. $479-480$.

29 Шире об этом: Э.Г. Бабаев, Роман и время. "Анна Каренина» Л.Н. Толстого, Приокское книжное издательство, Тула 1975, с. 10-22.

30 Л.Н. Толстой, Собрание сочинений в двадияати двух томах, т. VIII, Изд. «Художественная литература», Москва 1980, с. 33. 
сомнения. Оба собеседника Левина отличались самоуверенностью, он сам отличался сомнением в принципиальных вопросах и «недисциплинированностью мыслей». Выслушав их противоречивые ответы (священник отстаивал правду религии, Катавасов - науки), Левин остался недоволен полученным ответом и решил больше с ними не спорить, отложив выяснение вызывавших душевное волнение вопросов на неопределенное будущее.

В другой раз Катавасов посоветовал Левину обратиться за ответом на волновавшие того вопросы к трудам Спенсера. Левин перечитал труды Спенсера и других философов и нашел в них «искусственный ход мысли», не удовлетворяющий его поисков смысла жизни. «Прозрение» Левина произошло под влиянием истины, открытой ему мужиком Фоканычем: «жить для души и бога помнить», т.е. «жить по совести», но и при участии авторского слова. Повествователь, применив риторический прием ad personam: «Катавасов очень любил говорить о философии, имея о ней понятие от естественников, никогда не занимавшихся философией»31, подорвал авторитет Катавасова. Этот ученый-естественник, которому по наивности казалось, что он убедил Левина, не мог дальше оставаться его учителем. На вопрос поставленный им Левину, прочитал ли он Спенсера, тот признался, что не дочитал до конца, потому что Спенсер ему теперь не нужен. Левин пришел к истине, т.е. к вере в Бога, не в итоге споров с учеными людьми, не в результате их аргументированных выводов, а под влиянием простых слов мужика.Это показывает, что разрешение важных мировоззренческих сомнений произошло в результате дискредитации ученого диспута.

Опыт анализа философских споров из-за принципов в романе Анна Каренина позволяет сделать заключение о том, что писатель отдал пальму первенста религиозному началу перед научным. Путь героя к истине показывает, что автор Анны Карениной невысоко ценил научные аргументы, предпочитая им простые истины, внутреннюю работу личности, ее нравственное совершенствование.

Спор в романе Анна Каренина стал не только типом ситуации, в которой стороны пытались выяснить разногласия и прийти к соглашению, но сам как таковой стал темой обсуждения. Левин многократно задумывался над феноменом спора и каждый раз, обнаружив его софистический характер, сомневался в его целесообразности. Он отмечал, что спорщики старались дока-

31 Там же, т. IX, с. 400. 
зать друг другу то, что было им давно известно и что они вступали в спор не для того чтобы решить вопрос, а для того, чтобы скрыть от противника суть своих взглядов. Этому служила сосредоточенность на логических тонкостях и словах, т.е. эристических уловках, свидетельствующих о недобросовестных интенциях. В оценке Левина результат спора зависел не от силы доводов, а от случая: «вдруг сам полюбишь это самое (т.е. то, что утверждает противник - Б.О.) и тотчас согласишься, и тогда все доводы отпадают, как ненужные» 32 и от ясности изложения субъектом волновавшего его вопроса. Выводы Левина отражают скептицизм Толстого в отношении к спору как пути к истине.

Данное обобщение можно отнести к позиции авторов всех анализируемых романов. Изображенные в них споры указывали на существование проблем, но не не приводили к их решению. Выбор ценностей, которыми авторы особо дорожили, совершался не при помощи логической аргументации для их поддержки или опровержения, а на уровне событийном, путем испытания героев на верность этим принципам.

\section{IV.3. Споры в полемическом романе}

Шестидесятые годы- время столкновения дворянского и разночинского кодов культуры. Процесс смены системы ценностей проходил в атмосфере споров, получивших отражение в произведениях ведущих романистов. Непримиримость и бескомпромиссность взглядов субъектов споров потребовали усиления авторского голоса, что дало толчок к возникновению особой разновидности романа полемического.

Понятие «полемический роман» включает: а) соответствующее реальности видение "романной ситуации» 1860-1870-х годов; б) понимание жанровой индивидуальности и, одновременно, соприродности нигилистических и антинигилистических романов; в) представление об их эволюции, выразившейся в появлении модификациий полемического высказывания-произведения; г) понимание жанра как устоявшейся формы осмысления действительности, соответствующей духу времени ${ }^{33}$.

32 Там же, т. VIII, с. 435.

33 Н.Н. Старыгина, Русский полемический роман 1860-1870-х годов в ситуации философско-религиозной полемики, Изд. Языки славянской культуры, Москва 2003, с. 343. 
Павел Анненков первым опытом полемического романа назвал Взбаламученное море Алексея Писемского ${ }^{34}$, а Николай Страхов указал на Марево Виктора Клюшникова как полемический роман ${ }^{35}$. Полемический роман вырос на почве монологического романа, в центре которого находился герой-нигилист. В полемическом романе ему противопоставлялся герой - носитель традиционных нравственных и философских, обычно христианских ценностей. Структурообразующим фактором полемического романа является спор из-за принципов. Как в монологическом, так и в полемическом романе жанр спора использован для представления аргументов героев, но в полемическом романе сильно увеличивается значение голоса автора, оценивающего и интерпретирующего события. Цель спора в такой разновидности романа заключалась в разоблачении идеологических установок нигилистов-радикалов. Автор-повествователь часто искал союзника в читателе, который становился одним из персонажей - безмолвным участником или свидетелем происходящего. Спор при слушателях не был свободным обменом мнений. Победа в таком типе спора, как утверждал Поварнин, льстит тщеславию спорящих, которые ведут себя неестественно $^{36}$. Увеличение круга участников спора в полемическом романе продиктовано задачей усиления голоса автора, что придает спору еще больше значения, чем в других разновидностях романа и обязывает исследователя к внимательному изучению расстановки в нем эпистемологических и аксиологических акцентов.

Волну полемических романов, авторы которых боролись с принципами нигилистической антропологии, вызвал Тургенев, создав образ-понятие «нигилист», которое затем тиражировалось в разночинской прозе $1860-$ х годов.

Классическим образцом спора о принципах являются прения братьев Павла и Николая Кирсановых с Евгением Базаровым при поддержке со стороны Аркадия. Павел Петрович считал принципы обязательными для каждого человека, утверждая, что: «без принципов жить в наше время

34 П.В. Анненков, Литературные воспоминания, Изд. «Художественная литература», Москва 1983, с. 501.

35 Н.Н. Страхов, Из истории литературного нигилизма, 1861-1865, С.-Петербург 1890, с. 344.

36 С.Н. Поварнин, Спор. О теории и практике спора, Изд. «Флинта», Изд. «Наука», Москва, с. 18. 
могут одни безнравственные или пустые люди»37. Устоявшийся порядок жизни дворянской усадьбы Кирсановых нарушил приезд Аркадия с университетским товарищем Евгением Базаровым, которого тот отрекомендовал как нигилиста. Рекомендация Базарова как нигилиста оказалась достаточно уважительной причиной для обоснования неминуемости будущего спора из-за принципов, направленного на разоблачение идейного противника. Уже в ситуации первого знакомства потенциальных спорщиков намечены расхождения во взглядах и стиле их поведения. Базарова раздражали аристократические манеры Павла Петровича, щегольство в поведении и одежде, уход за телом, чрезмерное внимание к личному туалету, бытовое англоманство. Замечания Базарова в адрес Павла Петровича отличались иронией и касались таких деталей, как внимание к наружности и гигиене: «щегольство какое в деревне, подумаешь! Ногти-то, ногти, хоть на выставку посылай!», «этакие у него удивительные воротнички, точно каменные, и подбородок так аккуратно выбрит»38. На основании этих характеристик складывалось представление о культурной чуждости будущих оппонентов. Братьев Кирсановых раздражали в Базарове бесцеремонное нарушение правил светского этикета (Базаров потягивался и не стеснялся говорить, что он голодный), пренебрежение к внешнему виду (у него была не одежда, а «одежонка», полотняное пальто, испачканные грязью панталоны, старая шляпа, не чемодан, а чемоданишко»). В завершение ознакомительной встречи Павел Петрович сделал жест, предвещающий спор (он не подал руки Базарову и даже засунул ее обратно в карман). Смысл этого жеста можно считать началом невербального спора, который после объявления Аркадием, что его товарищ Базаров является нигилистом, превратился в спор вербальный.

Тезисом вспыхнувшего спора стала предложенная Аркадием дефиниция нигилиста: «Нигилист, это человек, который не склоняется ни перед какими авторитетами, который не принимает ни одного принципа на веру, каким бы уважением ни был окружен этот принцип» 39 .

То, что с точки зрения Аркадия было существенно в этой дефиниции: «не склоняется перед авторитетами» и «ничего на веру не принимает»,

37 И.С. Тургенев, Собрание сочинений в двенадиати..., т. III, с. 213.

38 Там же, с. 181.

39 Там же, с. 186. 
преднамеренно переиначивалось его дядей: «ничего не признает», «ничего не уважает» 40 . Здесь применена эристическая техника нарушения конкретного значения понятия путем его обобщения и придания ему другого смысла. Павел Петрович приписывал противнику мнения, сформулированные им с опорой на стереотип нигилиста, прибегал к насмешке и желчным остротам, неуместной иронии.

Простой обмен мнениями, по ходу которого стороны объяснили свое понимание определения нигилист, постепенно превратился в спор о принципах. Его приближение сигнализировано появлением в повествовательном пласте метафорических определений спора, почерпнутых из военной риторики как: «объявление войны», «схватка», «схватка произошла в тот же день за вечерним чаем».

Предлог спора оказался довольно банальным - соседний помещик был назван Базаровым «дрянью» и «аристократишком», что заставило Павла Петровича заступиться за принципы настоящих аристократов, такие как уважение своих и чужих прав, добросовестное исполнение обязанностей. Для Павла Петровича аристократизм сам по себе являлся «принсипом». Выступая от имени людей старого века, Павел Петрович признал принципы необходимыми в жизни и не сомневался в их истинности: «без принсипов, принятых, как ты говоришь, (т.е. Аркадий - Б.О.) на веру, шагу ступить, дохнуть нельзя», «без принсипов жить в наше время могут одни безнравственные или пустые люди» 41 и сослался в этом на исторический опыт. Соблюдение принципов он считал чертой хорошо воспитанных людей, т.е. представителей дворянской культуры. Ссылка Павла Петровича на исторический опыт и логику истории якобы подтверждающие необходимость высоких понятий была тут же оспорена Базаровым, что произошло путем контекстуального снижения высокого стиля противника: «Вы, я надеюсь, не нуждаетесь в логике для того, чтобы положить себе кусок хлеба в рот». Высокий риторический стиль Павла Петровича заменен здесь низким разговорным стилем Базарова, подчеркивавшим полное сословно-культурное отчуждение. Отождествление Базаровым «логики истории» с логикой бытовой, т.е. с рассудком, показывает совершенное им упрощение. Им употреблен эристический прием приписывания понятиям другого смысла. Павел

\footnotetext{
40 Там же.

41 Там же.
} 
Петрович на вербальном уровне спора придерживался правил «романтической риторики», пытаясь «говорить обо всем красиво». В то же время, как считают Дж. Лакофф и М. Джонсон: «язык спора - не поэтический, причудливый или риторический; он - буквальный ${ }^{42}$. Базаров последовательно осмеивал идиолект противника. Последнее замечание убеждает нас в том, что стилистическое различие языков обоих оппонентов, - возвышенно-поэтического и разговорного, - авторский прием, благодаря которому раскрывается разница между двумя культурными кодами: аристократическим и разночинским.

После формулировки исходных посылок в споре, стороны сосредоточились на конкретных темах. Базаров - на отвержении высоких, базовых с точки зрения Павла Петровича понятий, таких как «аристократизм», «либерализм», «прогресс», «принципы», которые он считал ненужными русскому человеку: «- Аристократизм, либерализм, прогресс, принципы, - говорил между тем Базаров, - подумаешь, сколько иностранных... и бесполезных слов! Русскому человеку они даром не нужны» ${ }^{43}$. Павел Петрович - на обосновании опровержения оппонентом. Он потребовал уточнения позиций, с которых произведено отрицание и поставил вопрос, в силу каких правил действует противник. В ответ Базаров назвал пользу как принцип поведения «новых людей» и отрицание как следствие этого принципа. Павел Петрович в очередной реплике сосредоточился не на пользе, а на отрицании. Он отождествил отрицание с разрушением и употребил для определения его размеров местоимение «всё» («всё стало быть отвергаете?») в значении: «наличие, не допускающее исключения». Эффект применения обобщающего определения усилен употреблением приема пропуска и умолчания: «но и ...». Очередные предположения Павла Петровича, касающиеся нигилистов, сформулированы в форме вопросов: «Значит, вы верите в одну науку?» или «Ну, а насчет других, в людском быту принятых, постановлений вы придерживаетесь такого же отрицательного направления?» ${ }^{4}$. На поставленные вопросы Павел Петрович не получил прямых ответов, но он их и не ждал, потому что ответы он составил заранее, основав

42 Дж. Лакофф, М. Джонсон, Метафорь, которьми мыл.живем, пер. А.Н. Баранов, А.В. Морозова, Изд. LKI, с. 27.

43 И.С. Тургенев, Собрание сочинений в двенадиати..., т. III, с. 213.

44 Там же. 
свое заключение на предпосылках a priori. Анализируемая ситуация не завершена выводом. Участники оборвали спор, сославшись на необходимость заняться другими делами.

Через некоторое время Павел Петрович потребовал от отрицателей изложения программы действий после разрушения, т.е. аргументов в поддержку их тезиса о необходимости разрушения существующей системы ценностей. Оппоненты уклонились от ответа, сославшись на исторический момент, требовавший единственно «расчистки места». Павел Петрович отождествил подобные планы с действиями, проповедуемыми материалистами. Предлагаемые молодыми людьми деструктивные средства («мы ломаем, потому что мы сила») позволили Павлу Петровичу отчетливее определить позиции сторон: нигилистам он приписал черты азиатских варваров, основанные на силе, аристократам - принципы, составляющие основу европейской цивилизации. Молодые люди прекратили спор, а отцы пришли к следующему выводу: «принадлежим к разным поколениям, не можем найти общего языка» 45 .

Расхождения в отношении к принципам характерны не только для старшего и молодого поколений, но проявляются и в среде молодых. Об этом свидетельствует спор друзей, вспыхнувший во время их пребывания на родине Базарова. Аркадий, реагируя на резкость суждений Базарова, упрекнул последнего в крайности, т.е. слишком основательном отрицании принципов. Он сам был за соблюдение меры в отрицании и готов был признать необходимость некоторых принципов. Базаров был непреклонен и лишний раз повторил, что «принципов вообще нет [...], а есть только ощущения» и объяснил, что он придерживается отрицательного направления в силу ощущения. Аркадий не разделил мнения товарища, за что был им обвинен в отсталости. Спор друзей едва ли не кончился дракой. Думается, что последний микросюжет отражает желание автора романа маргинализовать явление нигилизма. Вывод напрашивается сам собой: нигилистами являлось не все молодое поколение, а отдельные его представители.

Аргументация главных спорщиков - Павла Петровича и Базарова, сравнивается Аркадием с ходами шахматных игроков, а сам спор - с видом искусной игры, успех которой зависел от мастерства участников. Метафорическое определения Аркадием спора как игры почерпнуто им из

45 Там же, с. 219. 
обыденного опыта. Само отождествление спора с шахматной игрой снижает его значение и намекает на предрасположенность русских к пустым спорам. И действительно, словесные споры именуются Базаровым «пустой болтовней», потому что они не направлены на решение социальных вопросов, а касаются вопросов второстепенной важности, таких как отношение к искусству и литературе. По убеждению молодежи, спор не приведет к важным выводам, потому что сам по себе он является вздором. Сомнение в силе слова заменяется верой в силу физического разрушения как более перспективного способа решения спорных вопросов. Дополнительно оно обнаруживается в беседе Аркадия с Базаровым. Аркадий предрасположен к общим рассуждениям философского характера, что раздражает Базарова. Он сделал товарищу замечание относительно «общих мест» и правил полемического дискурса, т.е. формулировки тезисов и антитезисов («противоположных общих мест»). С этой целью он воспользовался примером силлогизма:

- А вот что: сказать, например, что просвещение полезно, это общее место; а сказать, что просвещение вредно, это противоположное общее место. Оно как будто щеголеватее, а в сущности одно и то же.

- Да правда-то где, на какой стороне?

- Где? Я тебе отвечу, как эхо: где?46.

Молодые люди пришли к выводу, что даже самое правильное логическое рассуждение является всего навсего риторическим приемом и не приближает к правде, т.е. спор оценен ими как ненадежный способ выяснения истины. Диалог-спор заменен привлекательным для молодежи отрицанием без необходимости его рационального обоснования.

В восприятии современников Базаров стал моделью «нигилиста», которому подражали реальные люди и по образцу которого создавались литературные двойники. Ответом на моду стали полемические романы, цель которых состояла в дискредитации типа нигилиста и романы о «новых людях», своеобразных модификациях типа нигилиста.

Творцом образцового романа о «новых людях» является Николай Чернышевский, создавший в разгар дебатов о Базарове и нигилизме роман

46 Там же, с. 293. 
Что делать?, в котором изобразил «новых людей» - позитивную альтернативу к понятию «нигилист» 47 . В слове повествователя автор уточнил, что «новые люди» задуманы им не как идеализированные, а как «обыкновенные порядочные люди нового поколения», единомышленники, с которыми читатели могли бы отождествить себя и которым могли бы подражать. Они названы «новыми», потому что у них были другие, чем у отцов, кумиры (они не шеллингианцы и не гегельянцы, а материалисты и огюст-контисты) и другие, чем у отцов, нравственные принципы, а именно «разумный эгоизм». «Новые люди» были заняты не спорами с отцами-ретроградами, а популяризацией собственного стиля жизни, основанного на философии утилитаризма и «разумного эгоизма». Повествователь, выступая от их имени, разделил людей на «развитых и неразвитых». «Развитых людей» он отождествил с собирательной фигурой «проницательного читателя» - объекта постоянных насмешек и иронии. Слово повествователя адресовано этому воображаемому собеседнику, с которым он вел своеобразную игру. Многочисленные обращения к «проницательному читателю» позволили ему установить контакт, но формальный, недиалогический. Повествователь приписывал «проницательному читателю» определенные мнения, не предоставив ему возможности возражать и ограничив его активность к предугадыванию реплик. Автор романа «разыгрывая речевое общение» 48 , отрицанию предпочел изложение в виде истории о жизни «новых людей», основанной на новых началах.

В главе Гамлетовское испьтание, посвященной руководящим принципам поведения героев, основному тезису Лопухова о пользе и выгоде как мотивировке поведеня личности противопоставлен антитезис Верочки о первостепенном значении возвышенных чувств и идеальных стремлений личности в социальном общении. В роли аргументов Лопухов использовал примеры, почерпнутые им из жизненной практики. Несмотря на упреки со стороны собеседницы в холодности и беспощадности провозглашаемой им теории, Лопухов продолжал придерживаться прагматических правил выгоды и расчета. Он убеждал собеседницу в преимуществе результатов

47 И. Паперно, Семиотика поведения: Николай Чернышевский - человек эпохи реализма, Изд. «Новое литературное обозрение», Москва 1995, с. 16.

48 См.: М.М. Бахтин, Эстетика словесного творчества, Изд. Искусство, Москва 1979, с. 251. 
поступков над их мотивами. Оппонентка согласилась с аргументами Лопухова, признавшись, что ей самой были отчасти смешны те возражения, которые она делала в ходе беседы и что она сама «давно думала в том роде». Таким образом, мы убеждаемся, что спор был на деле мнимым, а его участники были не оппонентами, а единомышленниками. Задачей автора было не обсуждение в споре принципов теории «разумного эгоизма» как основы поведенческого кодекса молодежи в ситуации смены ценностных ориентиров, а ее утверждение и популяризация.

Чернышевский отнесся к сложившемуся в шестидесятые годы стереотипу о пристрастии молодежи к спорам. Повествователь отметил, что в среде молодежи постоянно шли «взаимные опорочивания». Во время загородной прогулки молодые люди упрекали друг друга в «неконсеквентности, модерантизме, буржуазности», в романтизме и огюст-контизме, но участники мало заботились о заключениях, уставали от перепирательств и спору как форме обмена мнениями предпочтли игры на натуре. По наблюдениям повествователя редкие участники спора обладали полемическим искусством, а сам спор назван «потехой», т.е. видом развлечения. В итоге можно сделать вывод, что неумение героев спорить, доминирование одной точки зрения указывает на недиалогичный характер романа.

Роман Что делать? в качестве идейного и поведенческого катехизиса стал культовым для разночинской молодежи. Вместе с тем он стал знаковым, реминицентным текстом для многих писателей, а его философские положения послужили отправной точкой для дальнейших идейных споров в полемических романах. Он стал чужим словом в диалоге-споре героев повести Записки из подполья и романа Бесь Федора Достоевского, в которых отклик на события современной общественной и политической жизни более заметен, чем в других произведениях писателя. Поэтому обоснованным кажется рассмотрение их в том же ряду, что и полемические романы.

Герой Запискок из подполья задуман как «один из характеров протекшего недавно времени», т. е. «лишних людей», по гамлетическому складу личности расположенным к размышлениям. Несмотря на сосредоточенность героя на себе, он вступает в спор с целым комплексом идей своей эпохи, на которые намекнул в монологе и которые можно рассматривать как тезисы в предстоящем споре.

С точки зрения споров о ценностях самое важное значение имеет полемика подпольного человека с современными ему этическими теориями, 
прежде всего с утилитаризмом, основанным на категории пользы. Своими корнями теория «разумного эгоизма» уходила в просветительские концепции Ж.Ж. Руссо, Гельвеция и И. Бентама ${ }^{49}$, но в 1860 -е годы обогатилась позитивистской мыслью Д.С. Милля, Г.Т. Бокля и О. Конта 50 .

Герой Записок из подполья полемизировал с этическими установками как просветителей, так и позитивистов и с поведенческим кодексом «новых людей». Полемику с просветителями он начал с сомнения в справедливости их убежденности в решающем значении рассудка как блюстителя нравственности, противоставив данному утверждению тезис о значении свободной воли как атрибуте человека и свойстве его натуры. Для его обоснования он использовал не логические аргументы, а иронию в адрес противников, которые, по его замечанию, наивно думали, что достаточно быть просвещенным, чтоб стать нравственным: «научи человека, просвети, и он будет нравственным».

Полемику с позитивистами, ставящими нравственность в прямую зависимость от уровня интеллектуального и цивилизационного развития, подпольный человек начал с намеков на их аргументацию, указывающую на теорию Г.Т. Бокля как источник, и со ссылок на арифметическую формулу «дважды два», «таблицы», «календарь», отсылающих к учению О. Конта.

Герой расширил круг адресатов полемики. Ими стали приверженцы «выгоды и пользы», т.е. «новые люди», голос которых стал доминировать в общественном дискурсе шестидесятых годов. Ключевым словом в рассуждениях подпольного человека является «выгода», что указывает на утилитаризм как главный объект его полемической рефлексии. Как субъект спора он ополчился против утилитаристов, противопоставив рассудку «хотение, каприз и фантазию», присущие натуре человека. Боклевским представлениям о роли цивилизованности в нравственном прогрессе он противопоставил примеры варварства цивилизованных людей. По ходу рассуждений герой всячески стремился доказать всесилие воли, оправдать каприз как обоснование поступка. С этой целью он выстраивал гипотети-

49 G. Przebinda, Od Czaadajewa do Bierdiajewa. Spór o Boga i człowieka w myśli rosyjskiej (1832-1922), Nakładem PAU, Kraków 1998, s. 232-236.

50 Б. Оляшек, Русский позитивизм. Идеи.в зеркале литературь, Wyd. UŁ, Łódź 2005, s. 49-54. 
ческие ситуации, доказывающие превосходство в поведении человека своеволия над рассудком. В заключение подпольный человек противопоставил рациональному обоснованию этики, боклевским представлениям об определяющей роли умственного развития для нравственного прогресса и цивилизации значение натуры человека. Казалось бы, что утвердив свободную волю как неотъемлемое свойство человека, герой одержал победу в споре и установил собственную систему взглядов как альтернативную модель. Однако результат испытания, какому автор подверг героя во второй части повести По поводу мокрого снега показал, что на практике эта модель не сработала. В истории отношений с Лизой «умствование» противопоставлено «чистому сердцу», нравственная низость подпольного человека противопоставлена нравственному величию девушки «дна», проявившей к нему «любовь-сострадание». Она признана им олицетворением «живой жизни», ее квинтэссенцией. Известное в литературе и публицистике XIX века понятие-концепт «живая жизнь» противопоставлено Достоевским умственным концепциям просветителей и позитивистов.

Отметим, что спор о принципах основания нравственности разрешился не в результате логической аргументации, а на событийном уровне. После опыта общения с Лизой, олицетворяющей «живую жизнь», подпольный человек оказался в очередном тупике. Он не знал, где «живое-то живет теперь и что оно такое, как называется?». Данное признание перекликается с высказыванием Бахтина на тему полемического романа:

Герой не знает, чье мнение, чье утверждение в конце концов - его окончательное суждение: его ли собственное - покаянное и осуждающее, или, наоборот, желаемое и вынуждаемое или мнение другого, приемлющее и оправдывающее 51 .

Спор в Записках из подполья изображен в форме обращенного монолога. Его диалогический характер подчеркнут употреблением глаголов со значением говорения: «говорите вы», «отвечу я» и слов: «видите-ли», «но ведь» как сигналов несобственно-прямой речи. Подпольный человек как субъект спора воспроизводил вопросы, восстанавливал тезисы, предугадывал

51 М.М. Бахтин, Проблемы поэтики Достоевского, Изд. Художественная литература, Москва 1972, с. 134. 
ответы и эмоциональную реакцию оппонентов на свои реплики. Об этом свидетельствуют выражения: «смотрите на меня с сожалением», «кричите мне», «прерываете вы с хохотом». Они показывают преобладание эмоций над логикой выводов и свидетельствуют о том, что писатель видел ограниченность логической аргументации в споре.

Очередной полемический роман Бесы основан на конфликте поколений и соответствующих им двух культурных кодов: дворянского и радикально-демократического, которые обнаружены не только в предметно-смысловом содержании, но и в стиле поведения и в языке. Степан Трофимович Верховенский - человек сороковых годов поставлен в ситуацию спора с сыном - представителем поколения шестидесятников. Их спор имел не личный, но идеологический характер. Это спор с поколением, которое отклоняло традиционные дворянские ценности, опираясь на комплекс нигилистических идей, на что указывает упоминание в романе имени Базарова и героев романа Что делать? Чернышевского.

В романе изображено несколько сюжетных ситуаций спора, но предмет во всех случаях - один и тот же: объяснение смысла происходящего и определение передовой идеи. Тезисом в спорах являлись мировоззренческие идеи, которыми увлеклось поколение шестидесятников, вербализованные в литературных произведениях Omцы и дети и Что делать? Степана Трофимовича поражала казуистика спора, уловки сына, переиначивание идей, которыми жило его поколение. Спор начатый по принципу а̀ propos, кончился констатацией Степана Трофимовича: «Мы вовсе, вовсе не к тому стремились; я ничего не понимаю. Я перестал понимать» 52 .

В другой ситуации герой вновь обратился к роману Что делать?, чтобы по этому «катехизису» шестидесятников лучше понять и изучить идеи, аргументы и принципы поведения молодежи.

- Я согласен, что основная идея автора верна, [...] - но ведь тем ужаснее! Та же наша идея, именно наша; мы, мы первые насадили ее, возрастили, приготовили, - да и что бы они могли сказать сами нового, после нас! Но, боже, как все это выражено, искажено, исковерковано! [...] К таким ли выводам мы устремлялись? Кто может узнать тут первоначальную мысль?53

52 Ф.М. Достоевский, Собрание сочинений в десяти..., т. VII, с. 229.

53 Там же, с. 320. 
Отметим, что идеалы героев романа Чернышевского считались Степаном Трофимовичем своими (припомним, что он стремился не отставать от молодых), но тут же им оспаривались как искаженные по смыслу. Это показывает, что в изображении Достоевского нигилизм детей был плодом отцов либералов сороковых годов. Сын считал идеи отца пережитком, а его самого называл отсталым человеком со старческими амбициями. Петр Степанович не полемизировал с идеями, которые ценило поколение сороковых годов, но прибегал к аргументам личного характера. Обнаружив злоупотребление доверием Степана Трофимовича со стороны генеральши Ставрогиной, сын не только не заступился за отца, но намекнул на своекорыстный характер его с ней отношений. Тем самым он опроверг значение свойственных отцу высоких чувств дружбы и любви, которыми дорожило поколение сороковых годов. Сын своим неуважительным отношением к отцу, проявившемся в несоблюдении норм поведения детей с родителями - бесцеремонностью, фамилярностью в обращении, грубостью, нарушил еще один важный принцип дворянской культуры - уважение к родителям. Он унизил отца назвав его «приживальщиком», «добровольным лакеем», «шутом ради денег».

Степан Трофимович ответил не рационально, а эмоционально. Он пригрозил сыну пощечиной, назвал его извергом и проклял. Финал показал, что сближение поколений на основе общности идеалов и принципов стало совершенно невозможным.

Еще более четко разобщенность поколений обнаружилась на благотворительном балу в Скворешниках. «Отцы» появились на нем с «ветвью оливы» и желанием мириться, «дети» жаждали «войны». Эти представители радикально-демократической силы оказались неспособными к диалогу с дворянско-либеральным лагерем.

Итак, спор в романе Бесы проявился и на поведенческом уровне, и в повествовательном вербальном дискурсе, но не разрешился. Позиция автора выявлена в ссылке на Евангелие как авторитетное слово, но интерпретация этого слова Степаном Трофимовичем не решила вопроса о ведущей общественной силе. Он истолковал фрагмент Евангелия от Луки, не определив, кто является «бесами»: «Это мы, мы и те, и Петруша... et les autres Avec lui, ...»54. Неоднозначность ответа отражает специфику спора в полифоническом романе, в котором он оставался открытым.

54 Там же, с. 681. 
В полемическом романе Алексея Писемского Взбаламученное море определяющей чертой исторического момента являлась неустойчивость. На это указывает заглавие романа, основанное на концептуальной метафоре «взбаламученное море». Основанием этой метафоры является лексема «море» как большое водное пространство в состоянии волнения, которое отмечено в эпитете - «взбаламученное». Метафора образована по принципу сходства русского общества с морем. В метафорической проекции заложена авторская цель - указание на шаткость состояния русского общества, находящегося в ситуации коренной перестройки экономических и нравственных принципов. Состояние шаткости и общественной неустойчивости поощряло писателя к попыткам влияния на формирование и стабилизацию взглядов современников. Отсюда следует важное значение полемик и аргументации героев.

Роман состоит из шести частей, каждая из которых содержит описание образа жизни в характерных топосах (в Петербурге, в губернском городе, в дворянском поместье, опять в Петербурге и за границей) в течение нескольких лет (1853-1861). Действие первой части романа происходит в столице, где познакомились будущие оппоненты. В первой части освещен генезис общественных и идейных позиций героев. Действие второй содержит изображение процесса поступающей идеологической дифференциации. Участниками идейных споров в романе изображены студенты; двое из них - Бакланов и Варегин, являлись приверженцами западнических идей профессора Грановского, которыми жила университетская молодежь сороковых годов. Третий, - Проскриптский, прототипом которого был, как полагает Анна Рошаль, Николай Чернышевский ${ }^{55}$, отличался радикальными социалистическими взглядами и бытовым аскетизмом. Молодые люди, исходя из ценностной системы дворянской культуры, назвали вздором социалистические увлечения Проскиптского и противопоставили им веру в истину, но не раскрыли ее содержания. Со своей стороны, Проскриптский подрывал авторитет истины, указывая на ее относительность в ситуации нравственно-идейного релятивизма и постоянной смены ценностей в обществе. Любое обоснование веры в идеалы он называл «упражнением в диалектике», а занятия диалектикой - «пустой игрой».

55 См.: А.А. Рошаль, Писемский и революиионная демократия, Изд. Азернешр, Баку 1971. 
Стороны спора так и не убедили друг друга. Радикалы не оценили наследия знаменитого историка Грановского, ученики Грановского не одобрили социалистических идеалов. Спор не привел к сближению позиций. Его участники разошлись в разные стороны, в буквальном (одни повернули направо, другие налево) и в переносном смысле (одни сосредоточились на личной карьере, другие - на революционной борьбе).

Участниками очередного спора стали те же студенты Варегин и Бакланов, но сам спор утратил свой жанровый характер, потому что проходил без участия оппонента, т.е. Проскриптского и являлся разновидностью беседы с симулякром. Предмет прежнего спора был ими забыт, а внимание участников было полностью сосредоточено на личности противника, т.е. на Проскриптском. Обсуждалось не содержание идеи, а ее носитель. Он был назван бывшими товарищами мистификатором и обманщиком, умелым спорщиком владеющим риторическим искусством, человеком не заботящимся о правде: «... на логические выводы мастер, а уж правды в основании не спрашивай...». Вывод напрашивается сам собой: молодые люди, дискредитируя противника, утверждали себя. Однако их авторитарность не осуждалась автором, но оправдывалась духом времени, что показывает тенденциозность автора в подходе к социализму и его приверженцам.

В другом известном полемическом романе Некуда Николая Лескова, откликнувшимся на идеологический радикализм шестидесятых годов, автора волновала судьба забредшего в тупик молодого поколения. В нем изображены поколенческие споры «отцов и детей» и споры исключительно в среде молодого поколения. Круг спорных вопросов был почти тот же, что и в романе Взбаламученное море. Это были идеи, которыми жило поколение «детей», такие как эмансипация личности и эмансипация женщин в особенности, брак и семья, терпимость, труд и т.п. Несмотря на предстоящие выводы, идейная позиция автора задана в заглавии Некуда. Оно звучит как констатация, осмысление ситуации и предсказывает недиалогичный подход в освещении волновавших общество проблем.

Роман состоит из трех частей: $B$ провиниии, В Москве, На невских берегах. Первая часть романа - В провинции отведена описанию жизни героев в провинции. Женни Гловацкая и Лиза Бахарева, новоиспеченные выпускницы института, вернувшись в родной город, легко нашли соратников в среде местной интеллигенции и вместе с ними образовали кружок 
передовой молодежи. Участники собирались по домам и вели бесконечные споры с «отцами».

Спорам поколений предшествовала оценочная характеристика их участников. Молодые названы автором «прогрессивными людьми уездного города», Старики - людьми добрыми, но «отстающими от современного образа мыслей», от передовых идей века. Сами «отцы» признавались в отсталости и искали симпатии «детей». Выступив в роли ретроградов, они были отодвинуты автором на сюжетную периферию романа.

Во второй и третьей частях романа на первый план выдвинуто молодое поколение, в недрах которого происходило идеологическое брожение. В их среде разыгрывался философско-религиозный спор о человеке. Он касался понимания человека, его биологической или духовной природы, а также нравственных основ и поведенческих принципов.

В спорах проходивших на московском этапе жизни героев радикалы проповедовали нравственный релятивизм, предлагали замену семьи свободными союзами, а воспитание детей родителями - общественным присмотром. Их оппонентом в проповеди нравственной революции изображен иезуит Ярошиньский, который с позиций латинской культуры защищал семейные устои, права женщин, незаменимость родительской любви как вырастающие из традиций римского закона. В этом фрагменте спора внимание автора сосредоточено на философской концепции человека. Мнения радикалов были основаны на материалистической антропологии, возражения поляка - на христианской. В споре доминировала аксиологическая цель.

Спор о человеке был продолжен на петербургском этапе жизни героев, при чем автор различил два круга нигилистов: представителей т.наз. «бурого» нигилизма и «правоверных» нигилистов-одиночек ${ }^{56}$. Первые во главе с нигилистом Красиным отстаивали биологическую природу человека и его бездуховность. Ими отрицались наличие в человеке высших нравственных качеств, таких как долг, доверие и уважение, отрицалась семья как пережиток, супружеская верность и родительская любовь к по-

56 Е.Л. Куранда, Повествовательная структура романа Н.С. Лескова «Некуда» в системе русского антинигилистического романа 1860-1870-х годов. Автореферат диссертации на соискание ученой степени кандидата филологических наук, Псков 2001, с. 10. 
томству. Их оппонентом выступил «нигилист-одиночка» Розанов - естественник и материалист. В репликах обращенных к товарищам, он пытался примирить материалистическую антропологию с базовыми для русской культуры ценностями, такими как любовь к семье, духовное обоснование любви как залога гуманизации. Результатом обмена мнениями на эти темы было убеждение в непримиримости идейных позиций. Красин оценил, что предложенное Розановым сочетание материалистической концепции человека с традиционными нормами и нравственными устоями жизни неприемлимо для членов кружка. Розанов проявил стойкость в своем несогласии с модными идейками. Авторская позиция в спорных вопросах философкой концепции человека и ее общественных последствиях выражена в попытках дискредитации одной из сторон спора, путем обнаружения ненаучности аргументации. Обе стороны обосновывали свое взгляды ссылками на науку, но толко Розанов опирался на оригинальные труды ученых, Красин же ссылался на переводные журнальные статьи, т.е. можно предположить, что его взгляды были плодом журнальной манипуляции. Он показан молодым человеком, увлеченным модными веяниями из-под знамени науки и попавшим в крайности подражателем. Розанов изображен человеком внимательно осмыслившим суть новых философских представлений о человеке, пытавшимся обогатить их русским историко-культурным опытом. Постепенно суть спора уходит на второй план, уступая место личным качествам спорщиков. Аргументация ad rem заменена аргументацией ad personam. В итоге, несмотря на интеллектуальное превосходство Розанова, участники спора встали на сторону Красина, обнаружив тем самым стадную психологию и некритическое отношение к лидеру.

Затем автор переносит действие в Петербург, где пропагандируемая теория нашла свое воплощение в общественном проекте «Дома Согласия», т.е. коммуны. Само название «Дом Согласия» вызывает положительные ассоциации. Его участники - бывшие московские почитатели Красина, изложили переселившемуся в Петербург Розанову основания проекта жизни в коммуне, такие как полное равенство, коллективизм, отказ от собственности, от семьи, индивидуальной стабилизации, положения, которые, припомним, в недавнем прошлом были предметом неразрешенного спора. Розанов, исходя из очевидности как способа убеждения, признал их проект утопическим. Риторике членов коммуны он противопоставил требование фактов, т.е. представления в качестве аргументов результатов 
опыта жизни в «Доме Согласия». По наблюдениям рассказчика, «Дом Согласия» постепенно превращался в «дом несогласия». Собрания жильцов «Дома», на которых делались временные отчеты и обсуждались правила коммунарского общежития, не завершались конкретными решениями, а участники расходились, не разрешив спорных вопросов. Как показала практика жизни в коммуне, постепенно рушились очередные принципы ее организации. Лидер Красин, призванный товарищами к ответу, прибегал к уловкам в споре, подменяя вопрос ответственности за провал проекта коммуны второстепенным по важности вопросом. Он уклонился от личной ответственности, объясняя неудачную попытку жизни в коммуне ментальными недостатками ее участников, т.е. «русской натурой». В ответ он был обвинен ими в самолюбии, жажде лидерства, подмене начал демократизма «аристократизмом и нетерпимостью». Жильцы стали понимать, что они были обмануты искусным манипулятором и один за другим покидали коммуну. Сами принципы коммунарской жизни не были ими оспорены (некоторые члены планировали организовать Дом Согласия в Москве). Вместо принципов они осудили личные качества исполнителя проекта. Спор о преимуществе коммуны как идеального воплощения социалистической идеологии над другими формами общественной жизни разрешился не на вербальном, но на практическом уровне провала эксперимента.

Итак, в романах Писемского и Лескова спор о принципах кончился разоблачением атеистически-нигилистической концепции человека, но произошло это с нарушением жанровых правил спора. Выполняя жанровые требования формулировки исходных тезисов и следовавших за ними антитезисов, авторы нарушали правила логической аргументации, уменьшали значение аргументов в споре, прибегали к уловкам и, таким образом, перемещали акценты с содержания идей на личные качества участников спора. На этом основании можно сделать вывод о том, что авторы стремились не к выработке истины в споре (цель гносеологическая), а к дискредитации одной из сторон спора (цель аксиологическая). Для осуществления аксиологической цели писатели использовали такие формы авторского участия в споре как заглавия в их метафорической функции, тезисные заглавия глав и разделов и самообнаружение автора. Усиление авторского слова в споре отрицательно сказалось на художественной стороне произведений. Полемический роман по своей сути стал тенденциозным, вовлеченным в споры на злободневные темы. По ходу прений был утрачен диалогический харак- 
тер спора, который в писательской практике Писемского и Лескова ушел в традицию софистического спора.

Как было упомянуто, к концу шестидесятых годов в России произошло «наступление» радикальных идеологий, распространившихся не только в Петербурге, но и в провинции. В привлекательности и силе воздействия нигилистических идей на молодое поколение лично убедился Иван Гончаров, совершивший в 1862 году поездку в родной Симбирск. На последнем этапе работы над романом Обрыв автор придал ему полемическую направленность, а спор стал в нем структурообразующим принципом. Одной из важнейших проблем, затронутых в романе, стало отношение старого поколения к системе ценностей молодых, что, в свою очередь, отсылает нас к вопросу об авторской позиции в определении пути, по которому должны пойти современники.

Исходной предпосылкой анализа споров о принципах в Обрыве Гончарова является трактовка его как антинигилистического романа - жанровой формы, удобной для внедрения в сознание читателей вопросов политических, социальных и нравственных 57 . Объектом интереса автора Обрыва стал человек, оказавшийся в эпицентре этих вопросов. Главные герои романа - Райский, Волохов, Тушин, Вера - определяют свои жизненные позиции в диалоге/полемике друг с другом. Наряду с внутрипоколенческим идеологическим спором идет спор со старым поколением. В роли наступающего предстал Борис Райский. Защитниками традиционных ценностей выступили бабушка и ее окружение, названное повествователем «лагерем неуступчивой старины».

Райский в отношениях со старым поколением действовал «смотря по обстоятельствам». Он то прибегал к резким аргументам «бросая в горячем споре бомбу в лагерь неуступчивой старины, в деспотизм своеволия», то «добродушно и снисходительно воевал с бабушкой», пытаясь таким способом сломать принципы «старого века», царившие в Малиновке-России.

Столкновение Райского с представителями старого поколения изображено в начале третьей части романа. В гостиной Татьяны Бережковой собрались родственники и местная знать: председатель палаты Нил

57 B. Olaszek, „Urwisko” Iwana Gonczarowa jako powieść antynihilistyczna, „Acta Universitatis Lodziensis" Folia Litteraria Rossica 2, red. B. Mucha, Łódź 2000, s. 86. 
Андреевич Тычков, священник, помещик Иван Петрович, чиновники. По ходу светской беседы возник спор, одной стороной которого оказался Райский, воспринимаемый местными как «столичный житель», представитель дворянской элиты с родословной в виде «исторических имен», другой, - Тычков и местный помещик. Интродукцией к спору послужило деление Тычковым людей на «новых» и «старых» с предвзятой им предпосылкой разоблачения первых и причисления к ним непосредственно Райского. Он потребовал от Райского четкого определения отношения к окружающим, т.е. обозначения исходных позиций в планируемом столкновении. Райский уклонился от прямого ответа, прибегнув к уловке, а именно нападению как форме защиты, состоящей в том, что сам стал упрекать собеседника в некорректном отношении к людям. Он обосновал свои упреки, ссылаясь на слова бабушки, ее авторитет и уважение к ней окружающих. Противник те же упреки использовал в функции контраргументов. Тычков, обращаясь к присутствующим чиновникам, призвал их засвидетельствовать его слова, будучи заранее убежден, что они не посмеют противоречить ему. Чтобы отвести внимание присутствующих от себя, он прибег к подмене темы и к обобщению. Вместо логической аргументации он сослался на стереотипы:

А послушаешь: «все старое нехорошо, и сами старики глупы, пора их долой!» - продолжал Тычков, - дай волю, они бы и того... готовы нас всех заживо похоронить, а сами сели бы на наше место, - вот ведь к чему все клонится! 58

Его вывод был нарочито преувеличен, но тем не менее убедил участвующего в споре помещика. Последний пришел к выводу, что стремление молодых вытеснить стариков не принесет положительных результатов и в подтверждение своего мнения привел не относящийся к делу пример бунтов венгров и поляков. Неумелая аргументация дискредитировала помещика как серьезного оппонента в споре с молодыми. Он выступил с позиций человека «осведомленного в политике», но его вопросы и выводы обнаружили его полный политический дилетантизм. В наивных рассуждениях помещика о международной политике проглядывал страх перед кре-

58 И.А. Гончаров, Собрание сочинений в восьми..., т. VI, с. 15. 
стьянскими бунтами, которых опасались все: он сам, Бережкова, Тычков. Именно страх перед утратой привилегированного сословного положения являлся общей платформой, объединяющей представителей старого поколения. Тычков видел потенциальный источник опасности в поведении молодых, в их атеизме и своеволии. Разрешение спора произошло не благодаря аргументации, а благодаря светскому инциденту, который скомпрометировал главного участника (Тычков обидел женщину, местную модницу, стиль поведения которой ему не нравился). Райский заступился за нее, разоблачив Тычкова как невоспитанного и нетерпимого человека. Он раскрыл перед собравшимися тайные грехи противника - взяточничество и ограбление им родственницы, т.е. прибег в споре с Тычковым к приему ad personam. Райского поддержала бабушка, которая привела новые доводы в споре, подтверждающие нравственную ничтожность гостя. Она выгнала из своего дома этого псевдозащитника старины и одобрила поведение Райского - порицателя старины. Отметим, что спор героев имел не возрастной характер (героиня по возрасту принадлежала к старому поколению, хотя не злоупотребляла преимуществами, которые давали ей уважение окружающих и почтенный возраст, не воевала, даже не спорила с молодежью, а скорее «наставляла» ее), а проходил в среде представителей одного поколения и являлся средством идейной дифференциации его участников. Этот спор длился на протяжении всего сюжетного действия и кончился тем, что Райский под влиянием житейской мудрости бабушки перестал возражать ей, воевать с ней и стал уважать каждое ее слово. В этом проявляется авторская позиция в вопросе отношения к т.наз. старине.

Самые принципиальные для шестидесятых годов вопросы обсуждались в идеологически неоднородной среде молодых. Это были споры о природе человека, духовной или биологической, о религии, браке и семье, о нравственной эмансипации. Они касались принципиальных вопросов: «Что такое правда?», «Как жить и чем руководствоваться в жизни?» Специфика спора на эти темы проявилась в наслаивании идеологического и любовного дискурсов.

Главными участниками споров изображены Вера и Марк Волохов, но с появлением Райского взаимоотношения героев осложнились. Райский и Волохов став соперниками спорили за первенство в местном обществе и в глазах Веры, которая должна выбрать одного из них. Можно сказать, что данная ситуация напоминает тургеневский способ определения 
передового деятеля, в соответствии с которым задача выбора поручена девушке, символически олицетворяющей Россию.

Райский с момента появления в Малиновке желал выполнять эмансипаторскую функцию в отношении молодежи. Он выступил в роли ментора по отношению к провинциальной кузине, считая собеседницу неравной себе по уму, понятиям и образованию. Он стремился привить ей новые передовые взгляды, но скоро убедился в том, что они у нее есть, и, таким образом оказалось, что почвы для идейных споров у них с Верой нет.

Постепенно главным оппонентом Райского становится Марк Волохов, которому в провинциальной среде сопутствовала репутация нигилиста. Первая их встреча носила ознакомительный характер. Довольно быстро выяснилось, что у них разные манеры и стиль поведения: дворянский и разночинский. Расхождения во мнениях обнаружились при попытке объяснить значение употребленных в разговоре определений, таких как «артист» и «искусство», которым они придавали разные смыслы: Райский - буквальный, Волохов - двусмысленный. Особо обыгрывается слово артист. Райский употреблял его в значении художник, Марк - в значении «человек, играющий роль на общественном поприще». Далее следовал спор вокруг оценки современного значения художников и политических деятелей. Марк низко ценил любовь к красоте и занятия искусством Райского, чем он напоминал Базарова. Он расширил значение слова артист, определяя им тех, кто притворялся, что занимается делом, а в действительности играл роль:

- Ведь все у нас артисты: одни лепят, рисуют, бренчат, сочиняют - как вы и подобные вам. Другие ездят в палаты и правления - по утрам, третьи сидят у своих лавок и играют в шашки, четвертые живут по поместьям и проделывают другие шутки - везде искусство!59

Объектом обсуждения стало отношение к жизни современников, проявляющееся в таких чертах как праздность и активность, расхождение слова с делом. Оба оппонента приписывали негативные черты друг другу, объясняли их источники, аргументируя свои позиции воспитанием и отсутствием подходящего поприща. Марк видел в Райском художника-неудачника,

59 Там же, т. V, с. 266. 
«лишнего человека», Райский в Волохове - «русского Карла Мора», «артиста» играющего роль «дон-кихота»:

Есть и дон-кихоты между ними: они хватаются за какую-нибудь невозможную идею, преследуют ее иногда искренно; вообразят себя пророками и апостольствуют в кружках слабых голов, по трактирам. Это легче чем работать. Проврутся что-нибудь дерзко про власть, их переводят, пересылают с места на место ${ }^{60}$.

Несмотря на эмоциональный характер спора, у оппонентов постепенно пропало желание спорить, и оба они остались при своих мнениях.

Как было сказано, симптомом рассматриваемого времени являлся спор в среде молодых. Его активной участницей стала Вера. В роковой сцене спора о принципах, происходящего в овраге, Вера защищала «вечную правду», т.е. христианские представления о человеке. Марк провозглашал «временные» идеи, такие как биологическая, материалистическая концепция человека, прививаемые обществу материалистами-естественниками. В рассматриваемом сегменте спора обыгрывается значение слов «правда» и «ложь». Вера противопоставила «новой правде» Марка «человеческую правду». Она защищала принципы, которые Марк считал ложью: «...все ложь, - а что правда - вы сами не знаете...».

Непосредственным предлогом к спору послужила пропагандистская деятельность Марка в среде гимназистов. Вера упрекнула Марка в распространении нигилистического учения: «Все отрицать, порицать, коситься на всех...». Однако, она готова была предположить, что нигилистическая пропаганда Марка скорее «рисовка, позированье, новый образ воспитания „грядущей силы”...», чем действительное отрицание. Вера оспорила обоснованность определения Марком его учения как «новой правды» и «живой воды», которыми он надеялся обольстить гимназистов. Не удовлетворенная красноречивой пропагандой Марка, она потребовала от него обоснования ценности провозглашаемой теории для молодого поколения. Марк уклонился от предоставления аргументов в поддержку тезиса, что его учение - правда и «живая вода». Благодаря библейскому и сказочному контекстам, - в Ветхом и Новом завете «живая вода» - это прообраз жизни

60 Там же, с. 281. 
вечной, в фольклоре - целебная вода, способная оживлять метрвое тело - употребленное Марком крылатое слово расширило тему спора, придав ему философский характер. Требование Веры к собеседнику избегать софизмов и придерживаться в споре эристических правил свидетельствует о рациональных основах мышления героини. Марк вместо удовлетворения призыва Веры обосновать теорию, переменил тему и, таким образом, показал себя недобросовестным спорщиком. Он не ответил на упрек в идеологической пропаганде и сосредоточился на опровержении принципов «человеческой правды», т.е. тех нравственных принципов, которых придерживалась Вера, и которые он считал проявлением отсталости и признаком ее принадлежности к старому поколению. Вместо следования испытанным нравственным принципам, чего требовала Вера, Марк предложил ей «опыт» жизни в конкретной ситуации, главную роль в котором он отвел себе. Он сослался на идеологему опыт, особо популярную в период увлечения общества естествознанием. Ссылку на «опыт» он считал аксиомой, не требующей доказательств. В анализируемой ситуации «опыт» имел узкое значение, относящееся к семейной жизни и означал совместный союз женщины и мужчины, так называемой «жизни на срок», продолжительность которого обусловлена успехом или провалом эксперимента. Вера оспорила перспективность «опыта», не пожелав лично стать подопытным кроликом в псевдонравственной пробе «жизни на срок». «Опыту» она противопоставила вечный союз мужчины и женщины, основанный на таинстве церковного брака и испытанный традицией. Марк в поддержку своего тезиса прибег к аналогиям из жизни природы. Расхождения в аргументации выявляют разные установки героев и отсылают читателя к актуальным философским контекстам, а именно богословской концепции человека Памфила Юркевича и к выводам материалистической антропологии в духе Николая Чернышевского.

В финале анализируемой сюжетной ситуации спора герои испытали чувство разобщенности, но были неспособны к уступкам в мировоззренческих вопросах. Ради верности убеждениям они были готовы пожертвовать любовью, несмотря на высокую цену разлуки. Значение, какое герои придавали воззрениям, свидетельствует о том, что их спор имел не личный, но идейный характер.

Стороны разошлись, чтобы спустя некоторое время возобновить спор на старые темы. Как в предыдущей ситуации, так и на очередном randez- 
vous в овраге, убеждения героев были те же, что и раньше. Биологическая концепция человека с ее практическими последствиями была противопоставлена укорененным в традиции нормам христианской религии, природные влечения - общественным правилам, натура - культуре. Казалось бы, что спор на эти темы имел личный характер, но в контексте поступающего в русском обществе разложения семейных устоев, его итог имел значение общественное, ибо касался коренных вопросов, которыми жили современники и сам писатель.

В споре с Марком героиня выдвинула тезис о значении долга. Лексема долг обыгрывается обеими сторонами. По мнению Веры, любовь приносит счастье, которое влечет за собой долг. Долг она считала нравственным принципом и понимала его как обязанность быть честной в отношении к другому, доверяющему человеку. Она подробно объяснила его понимание на личном примере. Вера осознала, что скрыв свои отношения с Марком от бабушки, она злоупотребила ее доверием и почувствовала себя «в долгу» перед ней. Марк со своей стороны предложил Вере забыть «долги». Он снизил высокое значение долга, приписав ему бытовое значение «ухода за...» и причислил долг к предрассудкам, от которых сам был свободен. Спорящие вновь остались при своих убеждениях. Вера восприняла аргументы Марка против «долга», «правил», «обязанностей» как софизмы, т.е. ложные высказывания. Источник заблуждений она усматривала в отсутствии корней в учении Марка, в его отрыве от традиции и книжном характере его взглядов. Марк же называл традицию, на которую постоянно ссылалась Вера, «подгнившими корнями» и в следовании традиции усматривал причину отсталости Веры от века. «Корням», т.е. традиции, Марк противопоставил увлечения. Заметим, что любое увлечение имеет временный характер и меняется вместе с обстоятельствами и модой. Противопоставление понятий: традиция - увлечение, выстраивает оппозицию: вечное - временное, смысл которой не оставляет сомнений в преимуществе точки зрения Веры над аргументами Марка.

Спор героев, состоявшийся при их последней встрече в овраге, разрешился не на словесном, а на событийном уровне. Финальный эпизод этой встречи завершился победой страсти. Победителем стал Марк, но только на время. Повествователь констатировал, что спор героев кончился «не победой того или другого, а взаимным поражением и разлукой навсегда». Марк в последовавшем письме Вере был готов к компромиссу, но только в личном 
плане, т.е. он согласен венчаться, но не отказался от своих идейных взглядов. Уступка заключалась в том, что он обещал Вере больше не касаться ее убеждений и не затрагивать спорных тем. Героиню не удовлетворили предложения Марка. Спор продолжен, хотя не вербализирован. Вера, восстановив в памяти аргументы за и против «новой правды», отклонила еe.

В длившийся на страницах романа большом споре о принципах появился Иван Тушин - носитель новых принципов. В обширном внутреннем монологе Райский осмыслил опыт знакомства с Тушиным. Монолог подчинен принципу pro et contra. Он адресован воображаемому оппоненту, иронически названному «умником», которому приписано мнение об «ограниченности» Тушина. Райский противопоставил ярлыку «ограниченность» значение природного равновесия силы ума с силами души и воли в человеке, усиленное их применением в жизненной практике. В сочетании ума и сердца Райский нашел секрет прогресса, значение которого он распространил на область общественной жизни. Ее основанием оказались идеалы гуманности, честности и справедливости:

Все соглашаются, что общество существовать без этого не может, что гуманность, честность, справедливость - суть основные законы и частной и общественной жизни, что «честность, честности, честностью» и т.д. 61

Природные нравственные качества личности противопоставлены им качествам приобретенным - «уменью жить», т.е. этике утилитаристов.

«Уменье жить» ставят в заслугу друг другу, то есть уменье «казаться», с правом в действительности «не быть» тем, чем надо быть. А уменьем жить называют уменье - ладить со всеми, чтоб было хорошо и другим, и самому себе, уметь таить дурное и выставлять, что годится - то есть приводить в данный момент нужные для этого свойства в движение, как трогать клавиши, большею частию не обладая самой музыкой62.

Райский пришел к выводу, что у Тушина, в отличие от большинства людей, руководствующегося шаткими правилами в жизни и в спорах, есть не-

61 Там же, т. VI, с. 386.

62 Там же. 
поколебимые принципы и личные качества, дающие ему право стать в современных русских условиях истинным представителем «партии действия».

В стилистическом плане спор изображен с использованием метафор («мертвая» жизнь и «живая» жизнь, «мертвый воздух», «долг»), цитат-клише, почерпнутых из языка радикальной журнальной публицистики («грядущая сила», «заря будущего», «юные надежды», «новая» женщина), крылатых слов библейского происхождения («живая вода», «фараоновы коровы»). Обращают на себя внимание «военные метафоры» использованные для описания хода споров. Спор, например, назван «тяжкой борьбой», «сражением». Определения адресатов идеологической пропаганды снабжены кавычками («новая сила», «новая женщина»), чтобы читателю стало ясно, что они употреблены в ироническом смысле. Ирония становится одним из средств выражения авторской позиции. Автор романа играл оттенками значений слов: «новая сила», «старая сила» «долг», прибегал к зоонимическим метафорам: «волчья ложь», «прямой вы волк» и к сравнениям с птицами и животными: ласточка, волк, медведь. В качестве средства аргументации он использовал поговорки: «волк оценил услугу журавля».

Позиция автора отражена в слове всезнающего повествователя, который, взвешивая силу аргументов сторон, подытожил результаты спора. Писатель ради художественной достоверности прибегал к приему несобственно-прямой речи и внутреннему монологу: «всё это (ход спора - Б.О.) пробежало в уме Веры», чтобы от её лица разоблачить «нового апостола» и «новую силу» и убедить читателей в правоте и значении «старой силы» для современников, на что дополнительно указывает употребление в речи повествователя антонимических эпитетов старый/новый.

Размышления Веры местами имеют публицистический характер. Становится ясно, что говорит не влюбленная девушка, не просто зоркий наблюдатель окружающей жизни, а тонкий аналитик современных идейных течений, каким способен быть только биографический автор, скрывающийся под маской повествователя. Однако насыщенность реплик оценочными эпитетами: «дерзкая речь», метафорами и сравнениями: «отживший сор», библейскими фразеологизмами: «фараоновы тощие коровы, пожиравшие толстых и не делавшиеся сами от того толще», 63 придают стилю высказываний художественный характер.

63 См.: Ветхий Завет (Бытие, гл. 41, ст. 1-4). 
Повествователь, отметив софизмы, зыбкость, односторонность, пробелы в аргументации, увлеченность гипотезами и умышленную ложь ради пропаганды, к которым прибегал герой, и - логику, волю, скептицизм, искреннее желание героини найти истину, раскрыл и разоблачил механизмы идеологической манипуляции, к которым прибегали пропагандисты. В комментариях повествователя обнаружился опыт и искусство Гончарова - строгого цензора радикальных публицистов.

Роман вызвал споры о молодом поколении и передовом герое 64 . Радикальные критики восприняли образ Марка Волохова как карикатуру на молодое поколение. Особо принципиальным его защитником стал Михаил Салтыков-Щедрин. В статье Уличная философия критик определил точки разногласия с Гончаровым в представлениях об этом типе. Особое внимание он уделил отрицанию как доминантной черте героя, сложившейся еще в образе Базарова и затем бытующей в антинигилистических романах. Критик оспорил обоснованность изображения Волохова как порицающего право на собственность, примитивно понимавшего «женский вопрос», отклонявшего общепризнанные авторитеты как не соответствующее действительности. Он, в частности, сосредоточил внимание на споре героев о принципах. Потребовав от автора романа почти научной обоснованности отдельных положений спорящих, рецензент как бы забыл о художественных правилах изображения. Последнее требование связано с эстетическими принципами представителей реальной критики, ожидавших от писателя «понимания общественных потребностей и социальных стремлений» 65 . Салтыков-Щедрин упрекнул автора Обрыва в следовании представлениям улицы о современном типе, в пробелах аргументации, неточности определений, тавтологии, в злоупотреблении двойным значением слов и отказал ему в праве быть судьей молодого поколения.

Близки критической оценке Салтыкова-Щедрина были также мнения других критиков. Николай Шелгунов в статье Талантливая бесталан-

64 См.: М.Е. Салтыков-Щедрин Уличная философия (1869), Н.В. Шелгунов Талантливая бесталанность» (1869), А.М. Скабичевский Старая правда (1869), М.К. Цебрикова Псевдоновая героиня (1870), Е.И. Утин Литературные споры нашего времени (1870).

65 С.А. Трубникова, Примечания, [в:] И.А. Гончаров в русской критике. Сборник статей, вступ. ст. М.Я. Полякова, Государственное издательство «Художественная литература», Москва 1958, с. 237. 
ность оценил, что в романе нет русских типов, а фигура Марка служит иллюстрацией того, каким герой не должен быть. Прибегая к реминисценциям из романа Что делать?, он ориентировал читателя на сравнение Марка Волохова с Рахметовым. Критик отказал Гончарову в праве решать современные вопросы. Спор Веры с Марком он назвал «пустыми препирательствами», «болтовней», «игрой в красивые слова». Критик не оценил должным образом важной роли Веры в персонажной системе романа. Отклоняя игровой характер спора, Шелгунов, подобно Салтыкову-Щедрину, не учел художественной специфики изображения и ожидал от писателя применения логических правил в споре Веры с Марком Волоховым.

Участие в споре о передовом герое и его поведенческих принципах принял также Александр Скабичевский. В статье Старая правда критик оценил всех трех потенциальных претендентов на это звание. Он воспринял тип Тушина как выдуманный «экстракт всевозможных добродетелей», созданный писателем в нравоучительных целях. В Райском он усмотрел тип романтического праздного художника, в котором доминирует донжуанское начало. В чертах Марка Волохова он увидел «ошибающуюся натуру, недоразвитого человека». Критик упрекнул писателя в том, что в изображении представителя молодого поколения он воспользовался не наблюдениями, а стереотипами. В оценке Скабичевского Гончаров создал тип архинигилиста, лишенного человеческих качеств. В ситуации критической оценки всех выведенных в романе типов он противопоставил писателю свое представление о «новом человеке», который по его представлениям был бы:

...честный труженик, упорным, усидчивым трудом зарабатывающий себе пропитание, человек, который жаждал бы распространять вокруг себя истину и посильное добро, жил бы просто, не любя излишней роскоши, его занимали бы исключительно общие интересы, касающиеся улучшения массы его соотечественников, и он был совершенно чужд узких, эгоистических принципов 66 .

Скабичевский гипотетически предположил, что симпатизирующая этому типу «новая женщина» занималась бы «малыми делами», т.е. учила бы ребятишек, шила манишки, занималась профессией повивальной бабки.

66 А.М.Скабичевский, Старая правда, [в:] И.А. Гончаров в русской..., с. 325. 
Критик заранее убежден, что подобные типы не нашли бы одобрения со стороны старого поколения.

Полвека спустя к вопросу о типе героя - представителя молодого поколения, выведенного Гончаровым на страницах Обрыва, обратился Владимир Короленко. В статье И.А. Гончаров и „молодое поколение” (1912) он повторил упреки предшественников к творцу образа «молодого поколения» в лице Волохова.

Критические отклики на роман послужили, как известно, побудительной причиной к написанию Гончаровым предисловия к первому отдельному изданию Обрыва и статей Намерения, идеи и задачи романа „Обрыв” (1872) и Лучше поздно, чем никогда (1879). Писатель задался в них целью прибавить несколько замечаний к роману, объяснить свои цели и намерения, отклонить упрек во враждебном отношении к новому поколению в лице Марка Волохова. Таким образом он подтвердил полемический характер романа.

Итак, беглый обзор полемики, возникшей вокруг романа Обрыв, в которой принял участие сам писатель, показывают движущие силы возникновения «русских споров». Их участники мало интересовались художественным достоинством романа и стремились утвердить свою точку зрения на затронутые писателем вопросы. Главной темой полемики стал тип героя - представителя «новой силы» и характер его изображения. Ключевыми в споре публицистов стала оппозиция «старое/новое», концепты «старая жизнь» и «новая жизнь», «старая правда» и «новая правда», «новая женщина» и «псевдоновая героиня», отразившие понимание спорящими действительности. Частотность употребления словообразований с компонентом «новый/новая» показывает, что русскую интеллигенцию больше всего волновал вопрос обновления русской жизни. Стороны спора остались при своих мнениях и не убедили друг друга.

\section{IV.4. Споры в полифоническом романе Достоевского}

Полифонический роман организован «по принципам обратной перспекmuвы, диалогического контакта с чужим сознанием и создания „последнего целого" на переходе границ между миром героев и действительностью 
читателя» 67 . В работе Михаила Бахтина Проблемы поэтики Достоевско20 особое внимание уделено отношению автора к говорящему герою. Оно стало критерием деления на монологический роман, в котором «голоса» героев подчинены авторскому сознанию, и полифонический роман, в котором они равноправны. Этому мышлению доступна диалогическая сфера бытия человека, которая проявляется, между прочим, в речевом жанре спора.

Спор в полифоническом романе представляет собой вид словесного состязания равноправных героев, обладающих полноценным кругозором и весомыми критериями оценки. Он уходит в традицию диалогов Платона, способствующих интеллектуальному взаимообогащению героев - носителей идей, согласно максиме «истина рождается в споре».

Изучение характера и функции спора в полифонических романах Достоевского - задача специального исследования. Рассматривая спор в романах этого писателя в одном ряду со спорами в романах других классиков, ограничимся наиболее характерными примерами. Писатель моделировал споры в виде сюжетных ситуаций, но не с намерением решить затронутые в них проблемы, а чтобы обозначить идейное многоголосие эпохи. Он и изображал идеи, и вел с ними спор.

Остановимся сперва на спорах, предметом которых были убеждения молодежи, содержание идей, которыми она увлекалась, и попытка определить, кто является их носителем и заслуживает звания передового человека. К ним принадлежит спор Петра Лужина с молодыми людьми в лице Раскольникова, Зосимова и Разумихина. Лужин, стремясь снискать их симпатию и желая показать себя передовым человеком, начал разговор с комплиментов в адрес молодежи, приписав ей черту деловитости. Его мнение вызвало полемику. Лужина поддержал Зосимов. Разумихин стал ему противоречить. Он признал за молодежью такие черты как желание добра и честность, но отказал ей в деловитости. Решение вопроса осложнилось различным пониманием деловитости участниками дискуссии. Разумихин намекнул на неспособность превращения идеи в дело: «идеи бродят, а деловитости нет», но не уточнил, что он понимал под делом. Лужин понимал дело как пропаганду идей, полезных с его точки зрения:

67 Н.Д. Тамарченко, Полифонический роман, [в:] Поэтика: словарь актуальHbıх..., с. 174. 
По моему же личному взгляду, [...] распространены новые полезные мысли, распространены некоторые новые, полезные сочинения, вместо прежних мечтательных и романических; литература принимает более зрелый оттенок; искоренено и осмеяно много вредных предубеждений... Одним словом, мы безвозвратно отрезали себя от прошедшего, а это, по-моему, уж дело-с...68

Он стал обосновывать свое мнение ссылками на заслуги молодежи в деле прогресса, совершаемого «во имя науки и экономической правды...».

Разумихин оценил аргументы Лужина как «общее место», т.е. избитые выражения, за которыми стояла прописная истина. Лужин в ответ воспользовался примером, иллюстрирующим изменения в понимании любви к ближнему. Христианскому пониманию любви как призыву делиться добром с ближним он противопоставил новое, основанное на науке ее понимание:

Наука же говорит: возлюби, прежде всех, одного себя, ибо все на свете на личном интересе основано. Возлюбишь одного себя, то и дела свои обделаешь как следует. И кафтан твой останется цел 69.

Легко заметить, что Лужин стремился убедить собеседников в преимуществе новой утилитарной этики. Он не успел этого сделать, потому что Разумихин предложил прекратить надоевшее ему обсуждение «общих мест» и решительно оборвал разговор. Это свидетельствует о расхождениях в понимании предмета спора, объектом которого для Лужина была утилитарная этика, а для Разумихина - он сам. Подобное понимание объекта спора у Раскольникова, которого интересовали не мнения Лужина, а он сам как потенциальный жених Дуни. Над спором ad rem восторжествовал спор ad personam.

В день поминок Мармеладова произошел новый спор с участием Лужина и Андрея Лебезятникова. Его темой стали «современные убеждения», под которыми понимались гражданские браки, права женщин и жизнь в коммунах. Лужин, задавая Лебезятникову многочисленные вопросы, провоцировал его к изложению идей, которыми тот увлекался. Молодого

68 Ф.М. Достоевский, Собрание сочинений в десяти..., т. V, с. 155.

69 Там же, с. 156. 
прогрессиста особо волновал стиль жизни ровесников. Лебезятников при обосновании поступков человека на первое место ставил значение обстоятельств и воздействия среды: «Все зависит, в какой обстановке и в какой среде человек. Все от среды, а сам человек есть ничто»70. В поддержку своих суждений он ссылался на знаковые для поколения шестидесятников произведения, пародийно перифразируя диалоги героев романа Что делать?, а также пользуясь сентенциями, почерпнутыми из публицистических и философских трудов Д. Писарева и Н. Чернышевского. Он отрицал принципиальные для дворянской культуры понятия, такие как благородство, великодушие, заменив их пользой как руководящим поведенческим принципом разночинцев и предпринимателей.

Лужин отвечал на отдельные тезисы Лебезятникова ироническими замечаниями, акцентируя свои консервативные позиции в вопросах нравственности, брака, жизни по принципу коммуны. В действительности он преследовал другие цели, чем опровержение изложенных Лебезятниковым взглядов «прогрессистов». Он спорил, исходя из прагматических и конформистских соображений: получить представление о кружках, чтобы, как признался сам: «на всякий случай забежать вперед и заискать у «молодых поколений наших». Кроме того, он хотел использовать Лебезятникова в качестве лояльного свидетеля при обвинении Сони в воровстве и ее компрометации. На основании поведения Лужина в споре читатель мог убедиться, что у него были недобросовестные интенции осуществить эгоистические узколичные цели, не имеющие ничего общего с образом мыслей современной молодежи. Можно сделать вывод о том, что функцией анализируемого спора было разоблачение одного из его субъектов.

Образ мыслей современной молодежи волновал и других героев романа. Внимание судебного следователя Порфирия Петровича привлекла статья Раскольникова O преступлении. Изложение ее содержания Порфирием Петровичем и Раскольниковым обнаружило расхождения в понимании главной мысли автора и стало исходной точкой предстоящего спора. На начальном этапе спора появляется ключевое понятие «новое слово» И «новые», т.е. те, кто это «новое слово» сказал. Для Порфирия Петровича «новое слово» - это положения статьи Раскольникова, а «новые» - синоним молодого поколения. Спор приобрел вид искусной игры судебного следователя,

70 Там же, с. 383. 
понимавшего свое дело как «свободное художество», с потенциальным преступником, но преступником особым, преступившим черту ради проверки принципа.

Порфирий Петрович умышленно упростил отдельные положения статьи, сосредоточившись на уязвимых местах аргументации Раскольникова, например, нечетких критериях деления людей на обыкновенных и необыкновенных, безнаказанности преступлений, совершаемых «необыкновенными лицами», «разрешению крови по совести». Раскольников, разгадав замысел Порфирия Петровича спровоцировать его к объяснениям путем искажения смысла статьи, притворился, что одобрил ее понимание, но в действительности стал припоминать старые аргументы и прибавлять новые, ссылаться на исторические примеры и таким образом обосновывать свой главный тезис о праве необыкновенных людей «преступать по совести». Порфирий Петрович по ходу расследования взглядов Раскольникова добивался ответа на вопрос, верует ли он в Бога, в Новый Иерусалим и в воскресение Лазаря. Ответ имел принципиальное значение для дальнейшего спора о принципах.

Разумихин следивший за ходом спора и выводами оппонентов, принял его за софистические упражнения, за интеллектуальное издевательство спорщиков друг над другом. Он обратил внимание на опасность выводов Раскольникова, особенно его аргумента об освобождении от судебного преследования преступлений, совершаемых во имя идеи, его ссылок на примеры поведения великих личностей ${ }^{71}$. Он понял, что Раскольников имел в виду освобождение преступника не от юридической, а от онтологической ответственности перед Богом. Особенно он был потрясен тем, что Раскольников разрешал «кровь по совести», т.е. отклонял нравственное наказание. Возмущение Разумихина разделил и сам Порфирий Петрович. Они оба увидели практическую опасность выдвинутого Раскольниковым принципа, о чем свидетельствуют гипотетическое предположение о возможных уголовных последствиях поступков «русских доморощенных наполеонов». Раскольников не исключил такой опасности, но минимизировал ее размеры и отклонил предположение, что он сам мог бы быть одним

71 Источником аргументов Раскольникова могла послужить вышедшая в 1865 г. в русском переводе Жизнь Юлия Цезара Наполеона III. См.: Г.М. Фридлендер, Послесловие, [в:] Ф.М. Достоевский, Собрание сочинений в пятнадиати mомах, т. V, Изд. «Наука», Ленинград 1989, с. 538. 
из них. Последняя оговорка относится не к сути спора, а к реальной ситуации расследуемого дела об убийстве процентщицы. Спорщики расстались, не убедив друг друга.

Очередной спор, субъектом которого выступил Раскольников, касался прежней темы - допустимости кровопролития «по совести». Он состоялся не под влиянием убедительных аргументов Порфирия Петровича и Разумихина, а по причине испытываемых Раскольниковым угрызений совести, его разобщенности с близкими людьми и, главное, в результате общения с Соней Мармеладовой. Инициатива принадлежала Раскольникову, который был потрясен историей семьи Мармеладова и желал повлиять на отношение Сони к жизни. Он рассуждал с позиций человека, который живет в мире, подчинящемся ритму цивилизации, выроссшей на фундаменте Просвещения и руководствуется разумом. Основной тезис спора с Соней не был им четко сформулирован и включал несколько мотивов: добро и зло, пути и способы борьбы со злом, самоотвержение во имя любви к ближнему, смысл жертвы и смирения, значение совести и нравственного закона. Он начал с анализа и разъяснения Соне трагизма ее положения, убеждения ее в бессмысленности личной жертвы в борьбе со злом. Соня же, которая жила по законам вневременной действительности, в мире мифа и ритуала, уповала на Божью волю. Раскольников стремился поколебать ее веру в Бога, постепенно открывал перед ней свои способы борьбы со злом, наконец, признался ей в убийстве и познакомил с мотивами, которыми он руководствовался. В качестве доказательства своей правоты он воспользовался приемом аналогии, примерами несправедливости, вопросами «кому жить?» и, таким образом, стремился убедить Соню в справедливости придуманной им теории. Соня в реплике сослалась на право Бога распоряжаться человеческой жизнью, противопоставила наполеоновским замашкам Раскольникова аргумент о достоинстве человека, который «не вошь», потребовала покаяния перед Богом и землею и добровольного принятия уголовного наказания. Раскольников подчинился ее требованиям, но окончательный отказ от теории произошел, как представляется, не в результате логических доказательств в предшествующих спорах, а под влиянием приснившегося ему сна, в котором он увидел провал мира, основанного на гипертрофии разума и принципах индивидуализма приведшего к отрицанию диалогизма в межчеловеческих отношениях и расторжению нравственных связей между людьми. 
Споры главных героев романа - Лужина, Лебязятникова, Разумихина, Раскольникова и Сони - убеждают в том, что автор принимал участие в общественной полемике начала 1860-х годов о «новых людях» 72 , но не всегда придавал значение логической аргументации.

Герой очередного романа - Идиот, вернувшись в Россию после многолетнего пребывания в Швейцарии, был поставлен автором перед необходимостью ознакомления с русской жизнью и русскими вопросами. На даче Лебедева в Павловске собрались гости, представляющие соответствующие круги русского общества тех лет. Среди них оказались дворянские консерваторы и новые либералы, деловые люди и нигилистическая молодежь, князь Мышкин и его соперник к сердцу Аглаи Евгений Павлович Радомский. Столь разнообразный состав гостей открывал возможность узнать разные точки зрения на жизнь, разобраться в гуще идей. Темой разговоров собравшихся на даче гостей являлись как личные дела, так и общественные проблемы, такие как женский вопрос, нигилизм, либерализм. Встреча началась с презентации участвовавших в ней лиц. Особо интересными оказались молодые люди, окружавшие Антипа Бурдовского, которых собравшиеся знали только по слухам. Лебедев в следующих словах охарактеризовал будущих оппонентов Мышкина:

Нигилисты все-таки иногда народ сведущий, даже ученый, а эти - дальше пошли-с, потому что прежде всего деловые-с. Это, собственно, некоторое последствие нигилизма, но не прямым путем, а понаслышке и косвенно, и не в статейке какой-нибудь журнальной заявляют себя, а уж прямо на деле-с; не о бессмысленности, например, какого-нибудь там Пушкина дело идет, и не насчет, например, необходимости распадения на части России; нет-с, а теперь уже считается прямо за право, что если очень чего-нибудь захочется, то уж ни пред какими преградами не останавливаться, хотя бы пришлось укокошить при этом восемь персон-с 73 .

Эта характеристика прозвучала прологом к предстоящему спору о последствиях нигилизма, таким как деловая и нравственная нечестность. Непосредственным предлогом визита нигилистов были, как известно, финансо-

72 См. Г.М. Фридлендер, Примечания, [в:] Ф.М. Достоевский, Собрание сочинений в пятнадияати..., т. V, с. 537.

73 Ф.М. Достоевский, Собрание сочинений в десяти..., т. VI, с. 291. 
вые претензии Антипа Бурдовского, выдающего себя за незаконнорожденного сына Павлищева, к князю Мышкину. Молодые люди, явившись к Мышкину без приглашения, затеяли перед великосветским окружением князя спор из-за победь 74 . В таком типе спора первостепенное значение имеют средства ораторской убедительности. Потому неудивительно, что в споре с князем они прибегали к словесному эпатажу, называли Мышкина идиотом и шарлатаном, вели себя вызывающе.

В качестве обвинительного акта ими была использована статья Келлера. Цель автора статьи состояла в убеждении потенциальных читателей в законности финансовых претензий Антипа Бурдовского и принуждению князя удовлетворить домогательство. Основным приемом аргументации Келлера стала клевета в адрес лиц, причастных к делу о наследстве, ложь и шантаж. Слушатели реагировали на прочитанное с возмущением, демонстрировали сильные эмоции. Реакцией князя было крайнее смущение в связи с поступком сочинителя, прибегнувшего к ложным обвинениям. Автор статьи, сам поступая бессовестно, одновременно апеллировал к совести и высоким чувствам князя. Он не скрывал юридической необоснованности требований, но рассчитывал на честь и совесть князя - качества, которыми сам не обладал. Келлер оставил удовлетворение финансовых претензий Бурдовского на усмотрение князя и сосредоточился на его личности, т.е. перевел спор из дела на личность. Сам Мышкин спорил «по-джентельменски». В главном вопросе - обоснованности финансовых претензий Бурдовского - он сослался на доказательства, полученные юристом Ганей Иволгиным. Ганя, опираясь на факты, логически опроверг аргументы, предъявленные Келлером. Князь в ответ на выпады личного характера, грубость в свой адрес он стремился смягчить их резкость. Это отражено в эмоциональном стиле реплик. Члены компании Бурдовского «восклицают», «визжат», «нападают с остервенением», «выходят из себя». Князь отвечал им «разгорячившись, громко, нетерпеливою скороговоркой, увлекшись, стараясь всех переговорить, перекричать», но затем, поняв, что эмоции помешают взаимопониманию сторон, «раскаивался в словечках и предположениях» и предложил оппонентам сесть и продолжить объяснение. Спор кончился уличением Бурдовского и его компании в денежном

74 Типология спора здесь и дальше по: С.И. Поварнин, Спор. О теории..., с. 25, 42 и др. 
обмане (суммы финансовых претензий назывались ими неточно и не были, вопреки утверждениям, полностью возвращены). Несмотря на это, князь в память Павлищева решил назначить Бурдовскому сумму в десять тысяч рублей. В итоге противники оказались побежденными не только силою логических доказательств, но и нравственно. В реакции пассивных участников спора доминировали эмоции страха, удивления, восторга. Князь Щ. и генерал Епанчин в знак негодования предложили пришедшим удалиться.

Осмысление спора и оценка поведения его участников поручена автором генеральше Епанчиной. Она была возмущена моральным обликом молодежи, ее атеизмом, потребительской психологией. Сцена, свидетелем которой она оказалась, позволила ей разобраться в том, кто есть кто. В оценке генеральши причиной хаоса и безобразия, царивших в современном мире, были молодые. Выступив в роли их настоящего оппонента, она указала на парадоксы их мышления. Нигилисты отрицали благодарность и одновременно ожидали благодарности со стороны других, отрицали уважение и требовали уважения к себе. Оказавшись в ситуации спора они заранее отказали противникам в правоте. Требуя от них соблюдения права, сами его не соблюдали, нарушая таким образом правила общественного сосуществования. Елизавета Прокофьевна выразила свое отношение не только к репликам посетителей Мышкина, но и к их идолам в лице героев романа Что делать?, культового произведения, популяризирующего новый, неприемлемый для старого поколения стиль поведения. Она как мать троих взрослых дочерей была возмущена поведением Веры Павловны. Генеральша возмутилась и тем, что поведение молодых не нашло соответственного противодействия. В качестве примера она привела реакцию Мышкина, неспособного ответить кампании Бурдовского так, как того требовали обстоятельства. Сцена спора нигилистов с Мышкиным неожиданно завершилась чаепитием, страсти на время улеглись, но окончательные выводы сделаны не были. Можно предположить, что в замысле автора поведение героев в споре должно было служить разоблачению нигилистов.

Очередной крупный спор вспыхнул на светском рауте у Епанчиных. В нем приняли участие хозяин и друзья дома. Предлогом для спора стала информация старика-англомана об обращении Павлищева в католичество. Известие сильно взволновало князя Мышкина, что можно объяснить традиционно критическим отношением православных верующих к католичеству, переход в которое по российским законам считался тяжким престу- 
плением ${ }^{75}$. Князь Мышкин, не поверив услышанному, высказал мнение, что католическое вероисповедание по сути является нехристианским: «Католичество - всё равно что вера нехристианская!». В поддержку этого мнения он сослался на аналогию между римским католичеством, отождествляемым с папством, и Западной Римской империей. В его представлении общей чертой папства и Римской империи было насилие как способ подчинения противников.

Папа захватил землю, земной престол и взял меч; с тех пор всё так и идет, только к мечу прибавили ложь, пронырство, обман, фанатизм, суеверие, злодейство, играли самыми святыми, правдивыми, простодушными, пламенными чувствами народа, всё, всё променяли за деньги, за низкую земную власть. И это не учение антихристово?!76

Мышкин мыслил исторически. Его главный оппонент Иван Петрович, упрекнул князя в преувеличении. Пассивные участники реагировали на чрезмерно эмоциональное выступление князя смехом, рассматриванием его сквозь лорнет, зловещими улыбками. Реакция участников спора не удержала князя от дальнейших аналогий католичества с атеизмом и социализмом. По ходу прений произошла заменена темы. Из комплекса пороков католичества - «порождения лжи и бессилия духовного», князь вывел современный атеизм и социализм, которые в его освещении явились, чтобы заменить нравственную власть религии, удовлетворить духовные запросы, но вместо этого присвоили насилие как надежный способ порабощения. Князь предложил противопоставить западной экспансии идей бездуховного социализма и атеизма русскую цивилизацию, русского Христа: «Надо, чтобы воссиял в отпор Западу наш Христос, которого мы сохранили и которого они и не знали!»77 Легко заметить, что в предложенном постулате идея религиозная объединена в единое целое с идеей национальной и противопоставлена бездуховному социализму западного происхождения.

75 А. Дремлюг, Католицизм, [в:] Идеи в Poccuи, Leksykon rosyjsko-polsko-angielski, pod red. A. de Lazari, Ibidem, Łódź, 2001, т. IV, c. 274.

76 Ф.М. Достоевский, Собрание сочинений в десяти..., т. VI, с. 615.

77 Там же, с. 616. 
Мышкин пытался объяснить присутствующим причины популярности атеизма в России, указывая на максимализм и увлеченность русского человека как определяющие черты:

Наши как доберутся до берега, как уверуют, что это берег, то уж так обрадуются ему, что немедленно доходят до последних столпов; отчего это? [...] И не нас одних, а всю Европу дивит в таких случаях русская страстность наша: у нас коль в католичество перейдет, то уж непременно иезуитом станет, да еще из самых подземных; коль атеистом станет, то непременно начнет требовать искоренения веры в бога насилием, то есть, стало быть, и мечом! Отчего это, отчего разом такое исступление? Неужто не знаете? Оттого, что он отечество нашел, которое здесь просмотрел, и обрадовался; берег, землю нашел и бросился ее целовать! Не из одного ведь тщеславия, не всё ведь от одних скверных тщеславных чувств происходят русские атеисты и русские иезуиты, а и из боли духовной, из жажды духовной, из тоски по высшему делу, по крепкому берегу, по родине, в которую веровать перестали, потому что никогда ее и не знали! Атеистом же так легко сделаться русскому человеку, легче чем всем остальным во всем мире! И наши не просто становятся атеистами, а непременно уверуют в атеизм, как бы в новую веру, никак и не замечая, что уверовали в нуль. Такова наша жажда! 78

Максимализм отличал самого князя как субъекта спора. Он хотел «всё объяснить, всё, всё, всё!», эмоционально реагировал на предмет и реплики оппонента («засверкал глазами», смотрел «огненным взглядом», «раскрыл рот от удивления», возвышал голос, кричал), рискуя компрометировать идею. Логическую аргументацию заменила эмоциональная, мешавшая успешному решению спорной темы. Подтверждением данного предположения может послужить реакция других участников спора на реплики князя:

„Старички” почти потерялись от первого изумления; генерал-начальник недовольно и строго смотрел с своего стула. Техник-полковник сидел в совершенной неподвижности. Немчик даже побледнел, но всё еще улыбался своею фальшивой улыбкой, поглядывая на других: как другие отзовутся?79

78 Там же, с. 617-618.

79 Там же, с. 619. 
Их смутила мышкинская увлеченность. Она показалась им уважительной причиной для прекращения спора. Сановник попросил князя успокоиться, предложив вернуться к теме в другой раз. В итоге оппоненты перестали слушать князя:

Иван Петрович крякнул и поворотился в своих креслах; Иван Федорович зашевелился; генерал-начальник разговаривал с супругой сановника, не обращая уже ни малейшего внимания на князя; но супруга сановника часто вслушивалась и поглядывала ${ }^{80}$.

Коммуникация между участниками нарушена, а важнейший вопрос о возможностях избежать западного влияния, угрожающего России в виде распространявшегося социализма и атеизма, не кончился заключением. Анализируемая сюжетная ситуация завершена припадком эпилепсии у князя. Автор больше не возвращался к затронутым в ней вопросам, а заключительные главы романа отведены решению личных судеб главных героев.

В итоговом для творчества Достоевского романе Братья Карамазовы нашло продолжение обсуждение важнейших для писателя вопросов, таких как вопрос о существовании Бога, о теократическом государстве, о нравственных последствиях атеизма и социализма.

В начале первой части романа писатель изобразил членов семьи Карамазовых, оказавшихся на «неуместном собрании» в келье старца Зосимы, целью которого было примирение поссорившихся отца и сына. Кроме хозяина и Карамазовых в собрании участвовали: либерал Петр Александрович Миусов, помещик Максимов, Калганов и Ракитин, монахи. Миусов соперничал с Иваном Карамазовым как представителем молодого поколения, которое оспоривало позицию людей сороковых годов, прививавших России передовые европейские идеи.

Предлогом спора послужила статья Ивана Карамазова о церковно-общественном суде, главный тезис которой был неоднозначен и давал возможности разных толкований. Этому способствовала своеобразная перемена объекта полемики. Первоначально им была тема церковных судов, которую затронул Иван. Его статья была откликом на положения другой

80 Там же, с. 624. 
работы о церковных судах, автор которой отверг отделение церкви от государства ${ }^{81}$. По ходу дискуссии тема церковных судов, церковного и государственного законов, превосходства церковного наказания над наказанием уголовным уступила место более важной теме взаимоотношений церкви и государства. Иван, полемизируя с предшественником, утверждал, что церковь должна представлять собой государство. Монахи также критически истолковали положения книги, с которой полемизировал Иван, предложив в качестве контраргументов собственный разбор соответствующих мест Евангелия, освещающих запутанный вопрос церкви как царства небесного и царства земного. Отец Паисий развил и одобрил тезис Ивана, указав на возможные последствия превращения церкви в государство в виде постепенного вытеснения религии наукой и цивилизацией. В осуществлении идеи превращения государства в церковь он видел миссию православия. Оба иеромонаха, Паисий и Иосиф, составили группу поддержки Ивана, хотя интуитивно понимали, что его идея - «о двух концах».

Сам Иван в слове, обращенном к старцу Зосиме, подчеркнул свою основную мысль, что не церковь должна искать себе подходящее место в государстве, а государство должно обратиться в церковь, которая, по его словам, «должна заключать сама в себе государство». В церкви-государстве он видел гарант нравственного возрождения и обновления человека и обосновал свое мнение ссылками на историю взаимоотношений христианской общины и римского государства в первые века христианства.

С репликой выступил Миусов. С позиций либерала-государственника он признал идею Ивана близкой по содержанию к социалистической утопии и сосредоточился на последствиях ее осуществления. Предметом обсуждения стало преимущество церковного или государственного видов наказания. Миусов упростил вопрос, гипотетически представив абсурдность положения церкви в роли судьи уголовных преступлений. Иван перевел вопрос на философский уровень. Он высказался за преимущество нравственного вида наказания над «механическим». Его поддержал старец Зосима, который, подчеркнув значение сознательного покаяния преступника и его духовной связи с церковью, сослался на сравнение нрав-

81 Как известно, это была работа М. Горчакова Научная постановка церковно-судного права (1875). 
ственного наказания, свойственного русской культуре с «механическим» наказанием, свойственным секулярной западной культуре. Он завершил свои размышления не логическим заключением, а пожеланием торжества «единой вселенской церкви».

Последняя точка зрения вызвала возражения со стороны Миусова, назвавшего идею превращения церкви в государство чудовищной. В ответ отец Паисий упрекнул Миусова в непонимании сути спора. Он отметил, что в прениях утверждалось противоположное мнение, а именно, не свойственная западному христианству идея обращении церкви в государство, а присущая восточному христианству идея восхождения государства к церкви. Миусов ответил анекдотом, указавшим по аналогии на опасность, угрожавшую современной цивилизации со стороны фанатиков теократии. Отец Паисий правильно воспринял остроту Миусова как аллюзию в адрес церковников, но окончательный вывод им не был сделан. Автор романа как главный режиссер ситуации спора вместо ввода очередной реплики, применил риторический прием диверсии, т.е. прекратил спор. На событийном уровне спор был прерван появлением Дмитрия, а после возобновления беседы ее участники сосредоточились на других темах. Таким образом, итог спора о теократии оказался неоднозначным, а его финал - открытым.

Писатель изобразил в романе ряд других ситуаций, участники которых вступали друг с другом в споры по идеологическим вопросам. Рассмотрим одну из них, состоявшуюся в доме Федора Павловича. В беседе за обедом участвовали Федор Павлович, Иван с Алешей и прислуга. Началом спора послужил рассказ слуги Григория, человека истово верующего в Бога, о преследовании христиан мусульманами. Он вызвал реакцию со стороны Смердякова, который выступил с рассудочных и атеистических позиций. Рассуждения Смердякова о допустимости отречения христианина от своей веры в ситуации угрозы утраты жизни постепенно превратились в принципиальный спор о существовании Бога. Использовав в споре с Григорием критерий здравого смысла в оценке достоверности доказательств существования Бога, он подготовил почву для выступлений настоящих отрицателей в лице Федора Павловича и Ивана. Хотя Федор Павлович назвал рассуждения Смердякова «казуистикой и иезуитством», но сам поставил перед сыновьями принципиальный вопрос: «есть бог или нет?» Со стороны сыновей последовали взаимоисключающие ответы: 
Иван отрицал существование Бога, Алеша утверждал противоположное. Аргументы Ивана отличались неоднозначностью. Отрицая существование Бога, он одновременно признавал значение Бога для цивилизации. Алеша считал отрицание Бога отцом и братом совершенно невозможным, ссылаясь в этом не на ум, а сердце: «Сердце у вас лучше головы»82. Спор был прекращен вторжением в отцовский дом Мити. Становится очевидным, что целью спора в рассматриваемой ситуации было не выяснение истины, а определение идейных позиций и поведенческих принципов его участников, в частности принципа «все дозволено», существенных с точки зрения дальнейшего развития событий.

Затронутая в монастыре тема теократического государства нашла продолжение в Легенде о Великом Инквизиторе. Иван изложил Алеше идею героя своей поэмы - Великого инквизитора об учреждении на земле Царства Божьего без Христа, но с папой как его заменой и инквизицией как стражей. Он изобразил в поэме реакцию Великого инквизитора на появление Христа, изложил понимание инквизитором свободы и руководившие им мотивы. Спор инквизитора с молчавшим Христом был завершен поцелуем Христа, после чего он удалился, а инквизитор так и остался при своей идее.

Вокруг идеи поэмы, комментариев и выводов Ивана между братьями возник спор. Алеша упрекнул Ивана в односторонности изображения инквизитора и в сочувственном к нему отношении. Он уличил брата в уловках, состоявших в использовании инквизиции, т.е. всего, что есть худшего в католичестве, для обоснования обобщающих заключений. Алеша не только отклонил аргументы Ивана в защиту инквизитора, но и предположил, что инквизитор сам в Бога не верит. В образе инквизитора Иван подменил веру в Бога любовью к человечеству и намекнул на существование тайного союза любителей человечества, напоминающего современную организацию масонов. Последнее заключение заставило Алешу заподозрить брата в симпатии к масонам. Как видно, Алеша был сосредоточен не на содержании поэмы, а на авторских интенциях Ивана.

Надо согласиться с мнением Валентины Ветловской, что в изображении спора братьев вокруг действий инквизитора преобладает установка

82 Ф.М. Достоевский, Собрание сочинений в десяти..., т. IX, с. 171. 
ad personam 83 . Автор романа сосредоточен не на определенной идее, а на компрометации персонажа - бунтаря-атеиста. Алеша завершил спор с братом христианским поцелуем, повторившим поцелуй Христа, которым тот простился с инквизитором. Смысл поцелуя неоднозначен, но повтор ситуации (поцелуй на прощание) возводит жест к уровню знака, заменившего в споре слово.

Настоящие и неопровержимые аргументы в пользу нравственной дискредитации Ивана, репутация которого еще в начале сюжетных событий была сильно подорвана, появились на этапе воплощения идейным «двойником» Смердяковым его идеи «всё дозволено» в действие. Смердяков, - писал Николай Лосский - «воплощение последовательного развития «просвещенства» (Aufklärum), ведущее к плоскому рационализму» 84 .

Вековечные вопросы о Боге, вере и безверии, занимавшие поколение шестидесятников, нашли отражение в галлюцинациях Ивана. К ним прибавляется вопрос о научной обоснованности картины мира. В больном сознании Ивана возник образ черта, который вступил с ним в игривый научный диспут, направленный на обоснование или опровержение убеждения, что Бога нет и, следовательно, «всё дозволено». Для изложения положений диспута Ивана счертом автор воспользовался не классической моделью спора-высказывания, а видом монолога, расписанного на голоса. Черт представлен в нем единомышленником Ивана, разделяющим его рационализм и «реализм». Парадокс аргументации черта заключался в ссылках на данные точных наук как на основание «земного рационализма» при очевидности фантастического статуса его собственного существования. Напрашивается вывод, что если наука, несмотря на уровень развития, бессильна в объяснении данного парадокса, то культ науки лишен смысла, а рационализм компрометируется. Валентина Ветловская объяснила допустимость фантастического возможностями художественной системы, вне которой оно не существует.

83 См.: В.Е. Ветловская, Поэтика романа «Братья Карамазовь»», Изд. «Наука», Ленинград 1977, с. 70-78.

84 Н.О. Лосский, Достоевский и его христианское миропонимание, Нью-Иорк 1953, с. 254, [Электронный ресурс] www.adinblago.ru.dostoevskiy/4\#5. [30 ноября 2014]. 
Для формально-логического доказательства ценно действительное, тогда как для доказательств, не сводящихся к формально-логическим, ценно и то, что не действительно, но вообще так или иначе допустимо 85 .

В споре с Иваном о существовании Бога черт только косвенно адресовал свои аргументы Ивану. Их подлинным адресатом были современные реалисты -приверженцы науки, на что указывает его ироническое замечание: «Это в бога, говорю, в наш век ретроградно верить, а ведь я черт, в меня можно» 86 . Черт умышленно нарушал правила логики, которыми руководствовались прогрессисты: «Тут у вас всё очерчено, тут формула, тут геометрия, а у нас всё какие-то неопределенные уравнения!» 87 . Он рассказывал анекдоты, издевался над человеческими пристрастиями, излагал и искажал доводы самого Ивана. В аргументах черта Иван узнал свои личные мысли и слова. Черт, истолковывая буквальный (не гипотетический) смысл взглядов Ивана, развивал их и отождествлял с конкретными философскими идеями, которыми увлекались «русские мальчики», например, идеей человекобожества и, обобщая, приписывал их современному русскому человеку. Финал беседы следующий: необыкновенному гостю не удалось завершить разоблачения оппонента-Ивана, потому что этому помешало внешнее обстоятельство (Алеша, постучав в окно, прервал его монолог).

Идеологическую позицию Ивана последовательно оспаривал Митя. Хотя между ними ни разу не состоялся очный спор, Митя несколько раз заявлял несогласие с Иваном. Например, на семейной встрече у старца Зосимы, он, выслушав изложенную Миусовым теорию Ивана «все дозволено», вдруг вмешался в разговор, уточняя, комментируя и запоминая мысль-тезис Ивана: «Злодейство не только должно быть дозволено, но даже признано самым необходимым и самым умным выходом из положения всякого безбожника»! Так или не так?» 88 Митя, вспоминая эпизоды общения с Иваном, пришел к выводу, что Иван - атеист: «У Ивана Бога нет. У него идея». Он обосновал этот тезис, ссылаясь на credo Ивана «все дозволено». Сам же

85 В.Е. Ветловская, Поэтика романа «Братья..., с. 81.

86 Ф.М. Достоевский, Собрание сочинений в десяти..., т. Х, с. 169.

87 Там же, с. 165.

88 Там же, т. IX, с. 91. 
Митя заявил противоположную позицию, о чем свидетельствуют слова: «Не в моих размерах» 89 .

Митя по своему темпераменту был не способен к логическому спору. В его репликах преобладали эмоции и аксиологическая установка. На этапе тюремного заключения его волновала этика - учение о высшей нравственности в ситуации увлечения общества естествознанием. Его оппонентом в этом вопросе стал Ракитин. Автор, воспользовавшись приемом несобственно-прямой речи, изложил слова Мити, адресованные Алеше, в которых он раскрыл планы Ракитина, касающиеся популяризации научной картины мира в сочетании с утилитарным обоснованием нравственной сферы. Мите, несмотря на перспективу появления «нового человека» стало «бога жалко». Он в пародийном духе изложил пропагандируемые Ракитиным теории современных физиологов по поводу человека, чтобы придти к ироническому заключению: «...вот почему я и созерцаю, а потом мыслю.... потому что хвостики, а вовсе не потому, что у меня душа и что я там какой-то образ и подобие, всё это глупости» 90 . В споре с Ракитиным Митя отстаивал значение Бога и бессмертия для человека, предостерегал о последствиях вседозволенности. У Ракитина - утилитарные критерии оценки поступков человека. Митя ценил ум Ракитина, но порицал его нравственные принципы. Он не понимал сути аргументов Ракитина: «Темно и неясно, зато умно»91. Вместо опровержения аргументов Ракитина, Митя разоблачал его самого, назвав корыстолюбцем и карьеристом. С этой целью он использовал аргументы ad personam, приписав Ракитину плагиат пушкинских стихов, упрекнув его в корыстном интересе к Хохлаковой. Таким образом, компрометируя Ракитина, он дискредитировал материалистические взгляды молодых социалистов. Сцена завершается гимном Мити Богу: «Да здравствует бог и его радость! Люблю его!»92 Ракитин в Боге не нуждался, ибо не ценил нравственного прогресса, предпочитая ему гражданские права и повышение социального уровня жизни.

Под влиянием Ракитина оказались мальчики-гимназисты. Их мировоззренческие поиски имели в освещении Достоевского особо важное

\footnotetext{
89 Там же, т. X, с. 107.

90 Там же, с. 102.

91 Там же, с. 103.

92 Там же, с. 105.
} 
значение в контексте роста популярности идей атеизма и социализма. Обратим внимание, что одна из глав романа озаглавлена Мальчики. Мальчики легко поддавались новым веяниям, выразителями которых были старшие. Они подчинялись Коле Красоткину, он же считал себя учеником Ракитина, но его внимание привлек Алеша Карамазов, которому сопутствовала слава мистика. В главе Раннее развитие Достоевский показал попытки Коли корректировать заблуждения Алеши в таких вопросах как наука и вера в Бога, социализм и семья, профиль образования - классического или реального.

Подходящим случаем поспорить оказалось посещение Алешей и компанией Коли Красоткина больного Илюши Снегирева. В начале предстоящего спора тринадцатилетний Коля определил свои взгляды, выступив как поклонник естественных наук и противник классической программы гимназического обучения, которые брал за основу в споре с Алешей. Алеша стоял на позициях человека, глубоко верующего в Бога. Основной тезис Коли: «Бог - «гипотеза» напоминает лозунги агностиков-позитивистов. Другой тезис: «Бог нужен для порядка и если бы его не было, надо бы его выдумать» уходит своими корнями в учение идейных кумиров Коли - Вольтера и Белинского, к которым дополнительно подключен контекст идейной позиции автора Письма к Гоголю. Мнение, что Христос был человекобогом, «гуманной личностью», которая в современных условиях встала бы на сторону революционеров, почерпнуто Достоевским из его бесед с Белинским, проходившим в 1845 году93. Апелляции Коли к авторитетам сопутствует их опровержение Алешей. Он задает Коле вопросы, на которые тот не способен дать исчерпывающие ответы. Таким образом, Алеша, обнаруживая поверхностные знания Коли, дискредитировал его «журнальное образование» и авторитет его учителей. Дискредитация осуществилось средствами пародии.

Другим приемом, послужившим опровержению аргументов Коли, стало указание на расхождение его слов с фактическим положением дел. Упрощение мы находим в высказываниях Коли на тему социализма. На вопрос Смурова, что такое социализм, он дал следующий ответ: «-Это коли все равны, у всех одно общее имение, нет браков, а религия и все законы как

93 См.: Георгий Чулков, Последнее слово Достоевского о Белинском, [в:] Достоевский, Москва 1928, вып. 3, с. 61-81. [Электронный pecypc] http://az.lib.ru/c/ chulkow_g_i/text_0320/shtml. [15 июня 2015]. 
кому угодно, ну и там всё остальное» 94 . Легко заметить, что ответ содержит избитые лозунги прогрессистов, в частности Ракитина - идейного наставника Коли. В очередной раз выяснилось, что у Коли ненадежные учителя, что его аргументация в споре сбивчивая, а сам он отказывается от только что сказанного, упрощает сложность затронутых проблем, в частности женского и семейного вопросов. Обнаружив идейные расхождения со своим наставником, Коля воздержался от предъявления доводов, ссылаясь на неопровержимый аргумент - опасность со стороны Третьего отделения, риторический прием известный под названием «призыв к городовому»95. В завершение Коля признался Алеше в том, что его радикализм - только поза, которую он принял, чтобы показаться прогрессивным. Роль Алеши в состоявшемся споре сводилась не к полемике, а к ниспровержению общих для Коли и «русских мальчиков» кумиров путем возражений и при помощи вопросов оппоненту. Спор завершен нравственной победой Алеши, который, благодаря такту и уважению к юному собеседнику, высокой культуре диалога, сумел расположить его к себе. Можно предположить, что в итоге состоявшегося личного объяснения с Алешей Коля в будущем откажется от своих ложных учителей и станет приверженцем Алеши. Вероятность данного предположения основана на словах Коли: «О, мы сойдемся, Карамазов».

Итак, романам Достоевского свойственно разнообразие мнений. В них доминируют споры героев на «проклятые вековечные вопросы». Они неразрешимы с прагматической точки зрения. Сознание неразрешимости предшествует свойственному следующему поколению уходу от реальной жизни в мир субъективных фантазий, ведет к религиозному ренессансу. Стремлению разрешить «проклятые вопросы» сопутствовала борьба с популярными на тот момент идеями, такими как социализм, просветительство и позитивизм. В этой борьбе писатель выступал за христианское обоснование нравственной системы русского человека и общественной практики. Противоборство тезисов и неразрешимость споров в пределах сюжетных ситуаций связано у Достоевского, как считает Надежда Кашина, с явлением полифонии 96.

94 Ф.М. Достоевский, Собрание сочинений в десяти..., т. Х, с. 23-24.

95 С.И. Поварнин, Спор. О теории и практике спора, Изд. «Флинта», Изд. «Наука», Москва 2009, с. 58.

96 См. Н.В. Кашина, Эстетика Ф.М. Достоевского, «Высшая школа», Москва 1989. 


\section{IV.5. Споры в рассказах Чехова}

Восьмидесятые годы - время нарастания в России нравственного и правового релятивизма. По сравнению с ведущими романистами, стремившимися в своих романах обсудить важнейшие русские проблемы, споры в чеховских рассказах имеют частный, камерный характер. Однако спор у Чехова является по мнению Андрея Степанова, одной из главных составляющих подлинного общения 97 . Актуальными вопросами, провоцирующими героев к спорам, принадлежали активное или безучастное отношение к злу, обывательщине и мещанству.

В рассказе Огни (1888) изображен спор, темой которого стала жизненная позиция молодого поколения и ее значение для прогресса. В нем участвовали инженер Ананьев, представитель старого поколения, и барон фон Штенберг - студент-практикант на строительстве железной дороги. Ананьев любил говорить на отвлеченные темы, т.е был человеком ментально расположенным к «русским спорам». Студента не привлекало толкование общих вопросов. Его мало занимали вопросы, затронутые Ананьевым: «все сказанное инженером было для него не ново и что если бы ему самому было не лень говорить, то он сказал бы нечто более новое и умное»98. Причины могли быть две: возраст и немецкое происхождение студента, на которое указывает фамилия фон Штенберг. Несмотря на заявление рассказчика, что «имя, вера, ум и манеры» были у студента русские, его реплики указывают на нерусский склад ума и культурное отчуждение.

Основной тезис Ананьева: лень и пессимизм молодых - помеха прогрессу, построен на контрасте отношения к жизни старого и молодого поколений. Ананьев в филиппике в адрес молодого поколения сослался на личный жизненный опыт. Рассказ о том, кем он был в юности, как ему на этапе взрослой жизни удалось осознать кто он, выработать нравственные принципы и убеждения и затем применить их в жизни, прозвучал упреком современным молодым. Владимир Катаев отождествил аргументацию Ананьева с проповедью, которая по своей природе не способна никого убедить

97 А.Д. Степанов, Проблемь коммуникации у Чехова, Изд. Языки славянской культуры, Москва 2005, с. 86.

98 А. П.Чехов, Полное собрание сочинений и писем в тридиати томах. Сочинения, Изд. «Наука», Москва 1985, т. VII, с. 110. 
в споре 99 . Студент отклонил значение убеждения и личного примера как способов переориентации отношения к жизни.

- Все это ничего не доказывает и не объясняет, [...] и все это одно только толчение воды в ступе! Никто ничего не знает и ничего нельзя доказать словами. [...]

- Надо быть очень наивным, чтобы верить и придавать решающе значение человеческой речи в логике. Словами можно доказать и опровергнуть все, что угодно, и скоро люди усовершенствуют технику языка до такой степени, что будут доказывать математически верно, что дважды два - семь ${ }^{100}$.

Таким образом, фон Штенберг выразил недоверие к слову и оспорил целесообразность словесных споров. Он подчеркнул это дополнительно своим поведением - лег спать, дав собеседнику понять, что не желает ни слушать его, ни говорить с ним. Его отказ от дискуссии можно считать сигналом нарушения межвозрастной коммуникации как культурного явления, обнаружившегося на закате XIX века. Мысль о бесперспективности споров усиливают слова рассказчика, соучастника беседы, который уезжая, констатировал: «... я не увозил с собою ни одного решенного вопроса».

Спор как форма обмена мнениями не внушал героям Чехова надежд на выработку компромисса в разрешении личных конфликтов. В этом контексте обращает на себя внимание заглавие повести Дуэль (1891), намекавшее на существование конфликта, который не мог разрешиться иначе, чем силовым способом. Предметом конфликта являлись наболевшие вопросы, такие как диктат научного мировоззрения и вынужденной активности. Спорить на эти темы стали доктор Самойленко и дьякон с фон Кореном. Лаевский стал в их споре объектом, олицетворением пороков. Его образ жизни использовался сторонами спора в качестве аргумента при обсуждении принципов отношения к жизни. Отметим, что Лаевский и фон Корен оставались в конфликте друг с другом. Несмотря на то, что их интеллектуальный облик формировался в шестидесятые годы, они представляли собой разные ментальные и психологические типы «людей восьмидесятых

99 В.Б. Катаев, Проза Чехова: проблемы интерпретаиии, Изд. МГУ, Москва 1979, c. 34.

100 А.П. Чехов, Полное собрание сочинений..., т. VII, с. 137-138. 
годов». Их отличали жизненные принципы. За обедом у Самойленко фон Корен в следующих словах прокомментировал образ жизни и круг интересов Лаевского:

Наш век, по его мнению, плох и хуже сороковых и шестидесятых годов только потому, что мы не умеем до самозабвения отдаваться любовному экстазу и страсти. У этих сладострастников, должно быть, в мозгу есть особый нарост вроде саркомы, который сдавил мозг и управляет всею психикой. Понаблюдайте-ка Лаевского, когда он сидит где-нибудь в обществе. Вы заметьте: когда при нем поднимаешь какой-нибудь общий вопрос, например о клеточке или инстинкте, он сидит в стороне, молчит и не слушает; вид у него томный, разочарованный, ничто для него неинтересно, все пошло и ничтожно, но как только вы заговорили о самках и самцах, [...] глаза у него загораются любопытством, лицо проясняется и человек оживает, одним словом. Все его мысли, как бы благородны, возвышенны или безразличны они ни были, имеют всегда одну и туже точку общего схода ${ }^{101}$.

Самойленко воспринял эту характеристику сердито, дьякон отреагировал смехом. Фон Корен на основании представленной им самим характеристики Лаевского сформулировал тезис «лаевские приносят вред обществу» и стал убеждать собеседников в погубных последствиях поступков Лаевского для общества. Он обратил внимание на то, что Лаевский, притворяясь единомышленником Шопенгауэра и Спенсера, незаконно присвоил их позиции. Самойленко возразил фон Корену, но не привел конкретных аргументов, а сослался на общее представление о людях: «-Он, такой же человек, как и все». По его мнению Лаевский, несмотря на слабости, стоял на уровне современных идей. Фон Корен противопоставил снисходительному отношению доктора к слабым людям дарвинистский принцип, предлагая их «уничтожить как козявку». Он исходил в этом из положений борьбы за существование. Крайность мер, предложенных фон Кореном по отношению к Лаевскому, поразила и возмутила доктора. Самойленко был против цивилизации насилия. Спор естественным образом переключился с обсуждения объекта в лице Лаевского на его обличителя фон Корена. Доктор в критике фон Корена сосредоточился на его «не-русских» принци-

101 Там же, с. 372. 
пах отношения к человеку и назвал его «продуктом немецкой науки». Несмотря на то, что ни доктор, ни дьякон не одобрили социал-дарвинистских аргументов фон Корена, анализируемая ситуация все таки завершилась заключением последнего: «Не следует баловаться. Надо себя в руках держать»102.

В очередных ситуациях оба антагониста отказались от спора. Фон Корен не снизился до диалога с Лаевским, но короткими ироническими репликами спровоцировал его к невербальной реакции, т.е. к дуэли. Он без колебаний принял вызов на дуэль, усматривая в ней способ «проучить» противника, но заранее уверен, что дуэль кончится ничем. Лаевский также понимал, что «дуэль вообще глупа и бестолкова, так как она не решает вопроса, а только осложняет его, но без нее нельзя обойтись»103. В решительную минуту фон Корен отказался от примирения как способа разрешения конфликта. «Дуэль есть дуэль, и не следует делать ее глупее и фальшивее, чем она есть на самом деле»104. Лаевский, стреляя в воздух, поступил гуманнее фон Корена. Накануне отъезда фон Корен признался, что он не изменил своих убеждений под влиянием поединка, но ошибся в оценке Лаевского. Его слова: «...если не ошибаешься в главном, то будешь ошибаться в частностях. Никто не знает настоящей правды», дважды повторенные Лаевским, приобретают статус сентенции. Они отражают сомнение в целесообразности спора как пути к истине.

В повести Палата № 6 (1892) появляются два вида диалога - диалог-согласие и диалог-спор. В первом участвовал доктор Андрей Рагин и его приятель почтмейстер. Их позиции отличала идеализация прошлого и критическое отношение к настоящему. Обмен мнениями доктора с почтмейстером, как правило, завершался констатацией согласия: «совершенно верно», «согласен».

Другой ход приобретали беседы доктора с душевнобольным пациентом Иваном Громовым. Они превращались в неразрешимый спор. В начале автор начертил портреты спорщиков. Доктора Рагина он представил как гуманного, образованного, мыслящего, способного к анализу и обобщениям человека. Пациент Громов наделен критическим отношением

102 Там же, с. 372.

103 Там же, с. 427.

104 Там же, с. 446. 
к действительности, резкостью суждений, предрасположенностью к крайностям: «В своих суждениях о людях он клал густые краски, только белую и черную, не признавая никаких оттенков; человечество делилось у него на честных и подлецов; середины не было»105.

Спор возник в банальной ситуации вспышки гнева пациента, вызванной присутствием доктора, но касался не больничной бытовой обстановки, а принципиальных вопросов, таких как свобода и порабощение человека, нарушение нравственных законов, отношение к жизни, необходимость борьбы со злом и т.п. Слова пациента привлекли внимание страдавшего от провинциальной скуки доктора, мечтавшего об удовольствии общения с умным собеседником. По ходу очередных бесед доктор постепенно становился оппонентом своего пациента в вопросах о принципах постижения мира.

Несмотря на то, что интеллектуальный облик обоих спорщиков сформировался в атмосфере сциентистских идеалов шестидесятых годов, они по-разному представляли себе законы природы и жизни. Доктор утверждал значение ума, отличавшего человека от животных, признавал низменность законов природы, ссылаясь на закономерность и случайность, проповедовал в качестве руководства духовные позиции стоиков «успокоения в самом себе». Несмотря на то, что доктор высоко ценил ум, он оказался неспособным к адекватной оценке своей ответственности за окружающее зло.

Я служу вредному делу и получаю жалованье от людей, которых обманываю; я не честен. Но ведь сам по себе я ничто, я только частица необходимого социального зла: все уездные чиновники вредны и даром получают жалованье... Значит, в своей нечестности виноват не я, а время... Родись я двумястами лет позже, я был бы другим 106.

Неудивительно, что гнев Громова, испытавшего на себе беспорядки, царившие в больнице, сосредоточился на Рагине как виновнике, а спор приобрел персональный характер. Пациент назвал доктора вором, шарлатаном и палачом, олицетворившим насилие больничных служб по отношению

105 Там же, т. VIII, с. 76.

106 Там же, с. 92-93. 
к больным, человеком, нарушающим нормы нравственности. Доктор в духе стоиков рекомендовал собеседнику смириться с обстоятельствами:

- Вы мыслящий и вдумчивый человек. При всякой обстановке вы можете находить успокоение в самом себе. Свободное и глубокое мышление, которое стремится к уразумению жизни, и полное презрение к глупой суете мира - вот два блага, выше которых никогда не знал человек ${ }^{107}$.

Громов не разделил мнения доктора и свое несогласие выразил отказом от дальнейшей беседы с ним. Доктор, наоборот, ценил в Громове интересного собеседника, который «умеет рассуждать и интересуется именно тем, чем нужно» и назвал его своим другом. С перспективы доктора спор имел фатическую функцию.

В очередной ситуации доктор пытаясь успокоить эмоции пациента, стремился убедить его в ничтожности всего внешнего и в преимуществе внутреннего - источника душевного спокойствия. Доктор вместо признания очевидности - справедливости замечаний пациента о беспорядках в больнице (внешнее), - призывал его к стоическому отношению к жизни (внутреннее). Ссылаясь на авторитет Марка Аврелия ${ }^{108}$, он использовал прием, известный в риторике как argumentum ad verecundiam (замена аргумента ссылкой на авторитет). В ответ Громов оговорился незнанием и непониманием философских авторитетов («я не мудрец и не философ», «ничего в этом не понимаю») и противопоставил мнениям доктора аргументы, почерпнутые из органической теории жизни. Он назвал себя «органической тканью», реагирующей на внешнее раздражение страданием и признал непригодными советы стоиков игнорировать страдания во имя сохранения внутреннего достоинства. Он назвал их учение устаревшим и негодными для использования в России, где большинство людей ежедневно испытывает страдание и заключил свое рассуждение следующим выводом: «Да, так,

107 Там же, с. 97.

108 См.: А.П. Чудаков, Примечания, [в:] А.П. Чехов, Полное собрание сочинений..., т. VIII, с. 447-450; А.П. Скафтымов, О повестях Чехова «Палата № 6» и «Моя жизнь», [в:] Нравственнье искания русских писателей, Изд. «Художественная литература», Москва 1972, с. 381-403. 
повторяю, учение стоиков никогда не может иметь будущности, прогрессируют же, как видите, от начала века до сегодня борьба, чуткость к боли, способность отвечать на раздражение...»109

Громов, стремясь победить доктора в споре, применил аргумент аd personam, а именно, обратился к нему с личными вопросами, чтобы затем констатировать, что суждения доктора - чистая теория: «все это философия, самая подходящая для российского лежебока». Он заметил, что жизненный опыт беспечного человека не дает тому права быть советником страдающих. В оценке Громова доктор Рагин как оппонент в споре - несерьезен. Сам Рагин согласился с оценкой и признался, что спорил не ради решения вопроса, который неразрешимый, а ради удовольствия общения с Громовым как интересным собеседником. Несмотря на это заявление, их спор имеет второе дно, а именно касается толстовского принципа непротивления злу насилием. Хотя оппоненты не пришли к общему выводу в принципиальном вопросе жизненных позиций, но финал рассказа не оставляет сомнений в том кто прав: стоик доктор или взбунтовавшийся против «палатных порядков» пациент. В финале доктор испытав на себе грубость сторожа Никиты, понял наивность собственного подхода к окружающему злу, но не проявил агрессии. Философия непротивления, одобрение доктором существующего порядка вещей трагически сказались на его личной судьбе.

Очередной спор, изображенный в произведении Рассказ неизвестного человека (1893), интересен тем, что обещает ответить на вопрос о роли и перспективности спора в решении политических конфликтов и силовых средств их разрешения. Произведение было задумано в середине 1880-х годов, во время реальных политических процессов народовольцев и отхода участников Народной воли от идей организации. Сюжет следующий: герой-анархист планирует убийство политического противника, коим в его представлении являлся «государственный человек». Нанявшись лакеем сына своей потенциальной жертвы, он стал наблюдать его жизнь и нравы. Условия конспирации и статус лакея в доме не позволили герою вступить в прямую вербальную полемику с Орловым и его товарищами, поэтому он ведет с ними спор в своем сознании. О его политическом мировоззрении можно лишь догадываться по историческому контексту. Зато взгля-

109 А. П.Чехов, Полное собрание сочинений..., т. VIII, с. 102. 
ды противников он изложил достаточно внятно в форме косвенной речи. Разговоры, а точнее их содержание, приобретают статус тезисов в предстоящем споре. В них прозвучали утверждения, что Бога и бессмертия нет, что Россия скучная и убогая страна, интеллигенция безнадежна, а народ «спился, обленился, изворовался, и выродился», что науки в России нет, литература неуклюжа, торговля нечестна, а женщины развращены. Приведенный перечень пороков достаточно богат, чтобы обосновать необходимость и неминуемость спора «неизвестного человека» с остальными героями. Он наблюдает поведение главного оппонента, прежде всего его отношения с любовницей и товарищами, чтобы затем отметить релятивизм их взглядов, нравственный индифферентизм и на этом основании ответить тому репликой в виде письма. На первом плане здесь оказываются не взгляды, а личные качества противника. Однако, благодаря метафорам: «европейский фрак», «душа в халате», которые он как субъект спора употребил в описании противника, отсылающим к символической гончаровской оппозиции сюртука и халата, объектом критической рефлексии стали традиционные национальные вопросы о проевропейской или восточной жизненной ориентации русского человека. Несостоявшийся террорист отметил поверхностный характер причастности Орлова к европейской культуре и еще усилил аргументацию ссылкой на азиатские черты, противоречившие его европеизму.

Примечательно, что по ходу мысленной полемики «неизвестного человека» с Орловым из нее полностью исчезают политические мотивы. Стирается идеологическое различие между субъектами спора. Я заменяется коллективным $\mathcal{M b}$, вместо итога, завершающей точки над «i», появляется риторический вопрос «отчего?». Само письмо неизвестного человека Орлову не завершено, оставляя поле для догадок. Герой бросает свои террористические планы. Политические убеждения утратили для него прежнее значение. «Неизвестный человек», как подобало политическому борцу, поощрял политческую активность, но как человек стал сомневаться в ее смысле:

Хочется играть видную самостоятельную благородную роль, хочется делать историю, чтобы те же поколения не имели права сказать про каждого из нас: то было ничтожество или еще хуже того... Я верю 
и в целесообразность, и в необходимость того, что происходит вокруг, но какое мне дело до этой необходимости, зачем пропадать моему «я»?110

Осмыслив свой опыт революционера, герой пришел к заключению, что мир идей широк и неисчерпаем и стал склоняться к идеалам обывательской жизни. В последней встрече с Орловым он в следующих словах изложил свое новое credo: «жить независимо от будущих поколений и не только для них». Орлов в финальной беседе сослался на бывшее письмо «неизвестного человека», но сосредоточился не на упреках в свой адрес, а на обобщениях, касающихся целого поколения. От имени восьмидесятников он советовал революционерам-романтикам сдержанность, отказ от эмоций и полный объективизм в оценках, ссылаясь в этом на значение судьбы, предопределения, воли Бога в жизни людей. Тем самым Орлов оправдал бездействие и индифферентизм поколения интеллигенции тех времен.

Собеседники так и не пришли к общему выводу в столь важном вопросе пассивности/активности современного человека и современного поколения. Орлов дал понять «неизвестному человеку», что разговор окончен, а он сам «взялся за шапку», после чего оппоненты разошлись. Несмотря на вывод Орлова о том, что они за полчаса сумели решить кучу вопросов, по нашему мнению, они ничего не решили, а спор оказался типично «русским спором» о смысле жизни, о счастье, которое мыслится в неопределенном будущем.

Выработка принципов отношения к жизни и их применение на практике стало сквозной темой разговоров героев рассказа Моя жизнь (1896). Мисаил Полознев, отказавшись от традиционных для интеллигента занятий и став вопреки самолюбию отца-архитектора простым рабочим, вынужден был постоянно обосновывать свой выбор жизненного пути. Таким образом, он поставлен самими обстоятельствами в ситуацию спора с традиционно мыслящими оппонентами. Инициатором споров выступал доктор Благово, о котором сказано, что у него была привычка «всякий разговор сводить на спор». Мисаил спорил с ним, «хотя обыкновенно оставался при своем мнении», что позволяет причислить прения героев к виду «споров ради споров»111. Причиной, заставившей Благово затеять

110 Там же, с. 213.

111 С.И. Поварнин, Спор. О теории..., с. 25. 
спор с Мисаилом Полозневым, был эксцентричный поступок последнего: оставить службу, отцовский дом и заняться физическим трудом. Благово заинтересовали мотивы выбора, совершенного Мисаилом. Уважая поступок Мисаила в принципе, он сомневался в его целесообразности. Он высказался против траты потенциала личности на физический труд вместо употребления его на осуществление таких целей как научные открытия или художественные достижения. Мисаил возражал ему, отстаивая значение физического труда как в нравственном, так и в социальном отношении. Его аргументы в пользу того, что все сословия должны заниматься физическим трудом, чтобы обеспечить элементарные потребности каждого и избежать порабощения и эксплуатации ближнего, являлись эхом толстовской доктрины опрощения.

По ходу беседы вопрос оценки совершенного Мисаилом выбора становился второстепенным, уступая место более важной теме о характере и целях прогресса. Мисаил выступал за нравственный прогресс, усматривая его «в делах любви, в исполнении нравственного закона». Благово был за «общечеловеческий, мировой прогресс в бесконечности», за непрерывное развитие цивилизации и культуры, которые, по его мнению, в далеком будущем выведут человечество на более высокий уровень развития.

Аргументация спорящих была направлена на обоснование преимущества конкретных и близких целей прогресса или, напротив, общих, рассчитанных на результат в далеком будущем. Благово упрекал собеседника в близорукости и ограниченности его кругозора конкретными задачами, такими как удовлетворение материальных нужд и осуществление социального равенства. Одобрив права сильных в борьбе за существование, он отклонил аргумент Мисаила о значении любви и нравственного совершенствования.

Если одни насекомые порабощают других, то и черт с ними, пусть съедают друг друга! Не о них нам надо думать - ведь они все равно помрут и сгниют, как ни спасайте их от рабства, - надо думать о том великом иксе, который ожидает все человечество в далеком будущем ${ }^{112}$.

112 Там же, т. IX, с. 221. 
Спор был оборван по чисто внешней причине - появлению сестры Мисаила, которую поджидал Благово. Это показывает, что несмотря на эмоциональное отношение к предмету спора, доктора больше занимала предстоящая встреча с Клеопатрой, чем убеждение Мисаила в превосходстве цивилизационного прогресса, основанного на борьбе и видовом выживании сильных. Есть все основания предполагать, что Благово вел спор не с целью убедить противника, но для того, чтобы приятно провести время ожидания. Мисаил спорил с ним, «хотя обыкновенно оставался при своем мнении». Мотивировка спорящих позволяет причислить их прения к виду «споров ради споров»113.

Позиция автора по отношению к спорящим выявлена на событийном уровне. Отношение к семье, которую Благово бросил, и к Клеопатре, которую он оставил, и поведение Мисаила в сложившейся ситуации не оставляют сомнений в том, что симпатия автора на стороне тех, кто придерживается правил любви. К подобному выводу пришел Анатолий Собенников, полагавший, что совесть в мире Чехова утверждается как высшая по отношению к знанию реальность 114 . Исследователь сослался в этом на журнальную полемику писателя со статьями Михаила Меньшикова в «Новом времени» как на контекст спора Мисаила Полознева с доктором Благово 115 .

Андрей Степанов объяснил позиции главных участников спора - Мисаила и Благово, «несочетаемостью идеологически правильной позиции с этически правильным поведением»116. Тем самым он смягчил резкость суждений Александра Чудакова о невозможности строго логического завершения спора, победы в идеологическом споре одной конкретной идеи над другой.

Споры, которые вели герои рассказов Чехова, можно причислить к типично интеллигентским спорам. Героев отличало желание просто поговорить об общих вопросах, о смысле жизни, верности идеалам, активном или пассивном отношении к жизни. Участники сами не верили в успех дис-

113 С.И. Поварнин, Спор. О теории..., с. 25.

114 А.С. Собенников, “Между „есть Бог” или „нет Бога...”(о религиозно-фбилособских традициях в творчестве А.П. Чехова», Изд. Иркутского университета, Иркутск 1997, с. 86.

115 Там же, с. 89.

116 А.Д. Степанов, Проблемы коммуникации у Чехова..., с. 98. 
куссий, спор не был для них путем к выявлению истины, а подходящим случаем для самоопределения. Те принципы, из-за которых они начинали споры, по ходу становились второстепенными. Ища истины, они в итоге к истине так и не приблизились. Возникает впечатление, что для Чехова важен не искомый результат спора, а сам спорщик - русский интеллигент на распутье.

\section{IV.6. Итоги}

Анализ споров о принципах в произведениях классиков можно завершить заключением об их тематическом разнообразии и незавершенности, т.е. об их «вечном характере». В центре внимания писателей стоял человек, которого волновал вопрос его личной позиции и принципов во взаимоотношениях с другими людьми. Спор был направлен на утверждение определенной системы ценностей и имел свою специфику в отдельных разновидностях романа.

Итак, в монологических романах 1840-50-х годов доминировали споры о преимуществе романтического и прагматического отношения к жизни, обычно имеющего возрастную мотивировку. Идеалам молодости противопоставлен рассудок зрелого возраста. Подчеркивалась роль жизненного опыта как фактора трансформации системы взглядов и перехода на позиции старого поколения. В системе ценностей, которых спор касался, получила отражение смена парадигм романтической и реалистической, в мировоззренческом значении этих терминов. Значение последней возросло в 1860-е годы - время борьбы «отцов и детей» и столкновения дворянской и разночинской системы ценностей. Писатели сами кодифицировали культурные коды с присущей им системой ценностей, которые затем становились объектом очередных споров.

В полемических романах доминировала цель идеологическая - утверждения системы взглядов, присущей определенной идеологической формации. Она осуществлялась за счет утраты диалогического компонента. Реакцией на деструктивность идейных установок в споре о ценностях являлось утверждение значения христианской этики как основания нравственного кодекса русского человека.

В полифоническом романе Достоевского изображен философский спор о значении «вечных вопросов» в жизни отдельного человека 
и целого народа. Христианская этика противопоставлена в них этике утилитарной, религиозная парадигма - парадигме научной. Писателью не удалось разрешить «вечные вопросы» по причине их принципиальной неразрешимости, но также и по свойственной спорящим эмоциональности. Рациональное начало в спорах героев Достоевского свойственно тем их участникам, которые так или иначе связаны с западной культурой. Однако не они, а те которым присуще христианские ценности являлись победителями в спорах.

Споры в чеховских рассказах заранее обречены на неудачу, согласно авторской предпосылке «никто не знает настоящей правды».

Позиция авторов по отношению к ценностям и поведенческим принципам героев, выведенных ими на страницах романов, обусловлена их индивидуальными идейными и философскими взглядами. 


\section{Глава V}

\section{Споры о обустройстве России}

Интенсивность «русских споров» усиливалась в период смены эпох, когда менялись исторические условия, влиявшие на жизнь отдельных людей и целых сословий. К узловым вопросам русской политической истории XIX века, привлекшим внимание ведущих писателей, принадлежали реформы сверху (царей Александра I и Александра II), реакция на них тех, чьи интересы были нарушены и кто был ими разочарован и тех, кто ними радовался. Немаловажное значение имели споры николаевских времен, в которых доминировала тема выбора пути развития по западноевропейскому образцу или русскому патриархальному образцу. Очередная волна споров связана с восстановлением Александром III общественного порядка, разрушенного либеральным курсом политики его предшественника с последствиями в виде революционно-террористической активности и возникновения новых либеральных программ. Последняя стадия споров связана сусилением идеологии российской государственности и противодействием со стороны новых политических сил в виде политических партий.

На основании предварительного анализа материала можем выдвинуть тезис о постепенной политизации спора о обустройстве России, трансформации этого жанра в прикладной жанр политической речи. Внимательное наблюдение за ходом споров, изменением их характера поможет прояснить загадку формирования русской революционной мифологемы как альтернативы реформаторскому курсу.

\section{V.1. Споры преддекабристского периода}

Частым предлогом для споров были представления поляризованных общественных сил о настоящем и будущем России, путях и методах ее развития. Они обсуждались не только в произведениях на современные темы, но и в исторических, как, например, в романе Война и мир Льва Толстого.

События, изображенные Львом Толстым в романе Война и мир, переносят нас в первое десятилетие XIX века, что связано со свойственным 
писателю стремлением выяснить исторические причины явлений. В 1810 -е годы особое значение приобрели планы государственного преобразования существующего судебного, административного и финансового порядков управления, предпринятые Александром I. Они, как известно, имели своих сторонников и врагов. В художественном изображении Толстого в Войне и мире сторонником реформ был князь Андрей Болконский - пионер в деле освобождения крестьян, либерал по репутации, автор проекта по изменению военных уставов. Герой отправился в 1809 году в Петербург, где по словам повествователя проходило «огромное гражданское сражение» по разработке проектов. Он лично убедился в существовании оппозиции со стороны бюрократов и екатерининских вельмож к проектам партии преобразователей. Болконский оказался естественным противником военного министра Аракчеева - защитника крепостных порядков. В изображении автора Войны и мира Аракчеев недоброжелательно относился к любым попыткам изменения законов, соответственно, и к проекту, предложенному Болконским. Министр не был расположен к обсуждению проектов и о дискуссии с ним и речи быть не могло. Он мотивировал отказ в поддержке проекта излишком законов и несоблюдением законов уже существующих. Князь Болконский безуспешно стремился расположить к себе оппонента, который отнесся к нему с пренебрежением. При враждебных взаимоотношениях субъектов компромисс и продвижение проекта стали нереальными. Князя поддержал Михаил Сперанский, лидер преобразований при Александре I, действующий в опоре на идеалы разума и разумности. Болконский был очарован спокойствием, самоуверенностью и высшим искусством спора своего союзника в деле реформирования страны:

Он употреблял все возможные орудия мысли, исключая сравнения, и слишком смело, как казалось князю Андрею, переходил от одного к другому. То он становился на почву практического деятеля и осуждал мечтателей, то на почву сатирика и иронически подсмеивался над противниками, то становился строго логичным, то вдруг поднимался в область метафизики. [...] Он переносил вопрос на метафизические высоты, переходил в определения пространства, времени, мысли и, вынося отсюда опровержения, опять спускался на почву спора 1 .

1 Л.Н.Толстой, Собрание сочинений в двадиати двух томах, Изд. «Художественная литература», Москва 1980, т. V, с. 177. 
Доводы Сперанского были сжаты, просты и ясны, и князь восхищался ими и возражал автору только ради того, чтобы показать, что и у него есть самостоятельные мнения: «Ежели он возражал и спорил, то только потому, что хотел нарочно быть самостоятельным и не совсем подчиняться мнениям Сперанского» ${ }^{2}$.

При столь сильно выраженных качествах Сперанского окончательная форма уставов не имела шансов быть коллективным, выявленным в споре делом. Болконский быстро убедился, что обсуждение дел сосредоточено не на их сущности, но на процедурах и пришел к выводу, что его личная политическая активность является праздным занятием.

Подобная рефлексия возникает и в отношениях Пьера Безухова с масонами. Пьер увлекся их социально-нравственными идеями. Став полноправным участником ложи масонов, Пьер, общаясь с заграничными братьями-масонами, успешно изучил их тайны. Вернувшись в Россию, в дискуссии с великим мастером петербургской ложи на тему ее устройства и обновления, он призывал к христианской добродетели и отклонению насилия. Он, исходя из представления об общности масонских идеалов, надеялся на взаимопонимание, но быстро убедился в том, что «никакая истина одинаково не представляется двум людям» и что даже единомышленники понимают его слова по-своему, с изменениями, на которые он не мог согласиться. Он вынужден был вступить в спор с великим мастером. Тот возражал Пьеру, упрекая его в ложных интенциях, стремлении не к истине, а к проведению своей точки зрения, в увлеченности борьбой. Пьер ответил критическими замечаниями в адрес братьев. Отметим, что оба спорщика пользовались аргументами ad personam и не стремились к истине. Спор приобрел софический характер и не принес решения вопросов. Дискуссия оборвалась, а разочарованный Пьер уехал домой. Финал спора и последовавшая за ним убежденность Пьера в том, что масоны - далекие от практической деятельности «паразиты», отражает критическую авторскую позицию в отношении к масонству ${ }^{3}$.

2 Там же, с. 176.

3 См.: П.А. Бурышкин, Масонство в романе Л.Н. Толстого «Война и мир», [в:] Масонство и русская титература, сост. В.И. Новиков, Изд. Искусство, Москва 1998, с. 344-350. 
Путь Пьера к преобразованиям оказался продолжительным во времени. В финале романа, действие которого происходит в 1820-е годы, он изображен участником тайного общества. На этом историческом этапе Пьер спорит с Николаем Ростовым на тему актуальной политической ситуации. Он выдвинул тезис, что «все гибнет» и «все непременно лопнет». Он предложил подготовиться к перевороту, постулируя прибавить к масонскому лозунгу добродетели - независимость и деятельность. Его программа заключалась в «деятельной добродетели». Ростов был против тайного общества, способного, по его мнению, породить одно зло. Он был готов повиноваться и служить власти и Аракчееву, даже применить силу против политических противников. Участники спора, поняв щепетильность затронутого вопроса, прибегли к перемене темы.

Провал споров толстовских героев в важных вопросах государственных преобразований первой четверти века позволяет сделать вывод, что автор Войны и мира скептически отнесся к диалогу-спору как инструменту решения важных политических вопросов. Декабрьские события 1825 года показали, что политический диалог с властью был невозможен и сторонники преобразований вынуждены были выбрать силовой метод.

\section{V.2. Споры о путях развития николаевской России}

Тридцатилетие правления Николая I не только не решило старых проблем привилегий дворянства, крепостного права, ограничения политических свобод, но прибавило новые, такие как экономическая отсталость. Оно принесло новые идеологические программы официальной народности графа Уварова в 1830-е годы и славянофилов и западников - в 1840-е. Сторонники двух последних идейных группировок спорили друг с другом на страницах журналов и в публичных лекциях, в которых затрагивались темы проевропейского и патриархально-русского путей развития России 4 . С конца 1830-х годов в России становились все более популярными идеи социалистов-утопистов. Идейные споры 1830-40-х годов проходили

4 См.: В. Щукин, Русское западничество сороковых годов ХІХ века как общественно-литературное явление, Wyd. UJ, Kraków 1987. 
в кружках, участники которых изображены в художественной литературе, обогатив «русский дискурс».

Тема трансформации России от «старой жизни, через сон к пробуждению» стала сквозной в трилогии Ивана Гончарова, но в двух первых его романах герои не спорили прямым образом на тему необходимости смены старой жизни на новую, спор шел о перестройке сознания человека как субъекта изменений. Напомним, что в условиях наступления «железного века» опровергался взгляд на жизнь романтиков как несвоевременный и утверждался взгляд прагматиков, что изобразил Гончаров в романе Объкновенная история. Подобная установка преобладала в романе Обломов, в котором обсуждалось значение деловой активности в новых экономических условиях. На фоне других героев только Штольц наделен хозяйственным талантом, позволившим ему действовать в условиях капитализирующейся России, только он проявлял подвижность и понимал значение технического прогресса, возникновения сети путей сообщения для развития страны. Утверждение «штольцевского начала» происходило в романе не в форме вербальных прений, а в описании результатов поступков героя.

По-другому, т.е. в прениях, выражал свое мнение о политической злобе дня Иван Тургенев. Анализ его произведений позволительно начать с романа Дворянское гнездо, герои которого заспорили о проевропейском или традиционно русском пути развития России в условиях подготовки к отмене крепостного права. Спор был затеян столичным чиновником Владимиром Паншиным, который стал излагать перед Федором Лаврецким свое мнение о русских порядках. По словам рассказчика он с самоуверенностью петербургского высшего чиновника как шарами играл в беседе самыми важными административными и политическими вопросами. Он ставил себя на место правительства, предлагал меры в отношении к губернаторам. Произнесенный монолог служил не интродукцией к спору, а средством автохарактеристики себя как потенциального его участника. Повествователь подчеркнул сосредоточенность героя на себе: «...причем, не упустил случая изложить, как бы он все перевернул по-своему если б власть у него была в руках»5. Паншин «говорил красиво, но с тайным озлобленьем», «бранил»,

5 И.С. Тургенев, Собрание сочинений в двенадиати томах, Государственное издательство Художественной литературы, Москва 1954, т. II, с. 244. 
«возражал раздражительно и резко», проявляя сильные эмоции и возбуждая их у слушателей. Он назван повествователем «фокусником» и «дипломатом». Лаврецкому стало ясно, что Паншин стремится не к решению важнейших вопросов и выработке истины, а к тому, чтобы показать себя перед дамами, поэтому он решил ему не противоречить. Настоящее столкновение противников произошло во время очередного визита Лаврецкого у Калитиных. Инициатива спора принадлежала Паншину, который высказал мысль, что Россия в своем развитии отстала от Европы. Свой тезис он обосновал отсутствием у русских изобретательности и необходимостью все заимствовать у европейцев. Свои рассуждения на эту тему он заключил выводом, что русские должны приблизиться к Европе путем совершенствования государственных учреждений. Данную задачу он возлагал на государственных служащих, к которым сам принадлежал. Лаврецкий возражая Паншину, выдвинул противоположный тезис - о молодости и самостоятельности России. Он как представитель среднего поколения не уклонялся от ответственности за состояние русских дел, за легкомысленную растрату им самим времени и сил, но заступался за новых людей, которым принадлежало будущее. Спору героев сопутствовали сильные эмоции:

Паншин возражал раздражительно и резко, объявил, что умные люди должны все переделать и занесся, наконец, до того, что, забыв свое камер-юнкерское звание и чиновничью карьеру, назвал Лаврецкого отсталым консерватором, [...]. Лаврецкий не рассердился, не возвысил голоса (он вспомнил, что Михалевич тоже называл его отсталым - только вольтериянцем) - и покойно разбил Паншина на всех пунктах 6 .

Лаврецкий отказался от эристических уловок в споре, предпочтя им логическую аргументацию. Он указал на невозможность скачкообразного типа развития для России как оторванного от национальных основ. Паншин в ответ потребовал от Лаврецкого обоснования аргументов примерами его личной деятельности. Лаврецкий удовлетворил требование, сославшись на свои планы «землю пахать», т.е. преобразовать хозяйство, но сближения точек зрения спорщиков не произошло. Раздосадованный Паншин «замялся - и замял разговор», попытался перевести его на другую тему. Можно за-

6 Там же, с. 245. 
ключить, что цель затеянного спора была эристическая: Паншин рисовался перед провинциальным обществом, особенно перед дамами, Лаврецкий считал Паншина соперником в любовных делах и вступил в спор с Паншиным только ради Лизы. Однако исторический контекст - канун реформ «сверху» и споры славянофилов с западниками - указывает на общественное значение и актуальность затронутой им темы. Отметим, что очередной раз спор не разрешен положительным выводом, что не равнозначно отказу от этой формы обмена мнениями.

\section{V.3. Споры вокруг Великих реформ}

Согласно принятой в данном разделе установке придерживаться общественно-политической проблематики, попытаемся определить ведущие темы споров, ставшие откликом на проблемы, перед которыми оказалась Россия 1860-х годов. Это были споры на тему путей ее развития, ведущих общественных сил, радикальных и либеральных, корней радикализма и либерализма, отношения отдельных сословий к проводимым правительством реформам.

В романе Oтиы и дети споры сосредоточены вокруг ведущей общественной силы, решения принципиального вопроса о «легитимации», т.е. выявлении того, кто является передовой общественной силой и имеет право определять будущее России. На это звание претендуют в романе Павел Петрович Кирсанов и его брат, и также Базаров с Аркадием. Базаров с самого начала приуменьшал значение старшего поколения в лице Павла Петровича, назвав его «уездным», т.е. провинциальным аристократом, которым не стоит интересоваться. Этой исходной снижающей характеристике противопоставлена автохарактеристика Павла Петровича. Она осуществлена путем употребления риторического топоса мнимого утверждения. Самоопределение Павла Петровича построено по логической схеме тезис/антитезис/синтез. Он ставит вопрос кто я? - «дурак»/«путный человек»/«отсталый колпак». Спорным в этой цепи является представление сторон о «путном человеке». Для Павла Петровича «путный человек» - это человек, который, несмотря на пять лет прожитых в деревне, не забыл того, чему его учили. Соответственно, он сам подходил под данную дефиницию. Юный естественник Базаров последовательно, по пунктам, опроверг аргументацию Павла Петровича, подчеркнув приоритет образования не 
гуманитарного, а естественнонаучного, определив увлечение искусством как несвоевременное занятие и, тем самым, отказал ему в праве называться «путным человеком». Определение Павлом Петровичем себя «отсталым колпаком» подчинено логике мышления Базарова, но при этом оно не было логическим выводом прений, а метафорическим определением, содержащим скрытую иронию. «Человеком отставным» Базаров назвал и Николая Петровича, но тот ответил на оскорбительное определение не высокомерной иронией, как его брат, а желанием наладить диалог и взаимопонимание. Первые попытки Николая Петровича сближения с молодыми встретили препятствие с их стороны. Они были явно не расположены к диалогу. Базаров, например, избегал откровенных разговоров. Он решил для себя, что Николай Петрович плохой хозяин и отсталый человек. Постепенно становится ясным, что молодые представляют собой герметически закрытую группу единомышленников. В этой ситуации отец стал «заискивать» перед сыном не только ради поддержки родственных связей, но и ради того, чтобы идти в ногу смолодыми. Николай Петрович считал, что он выполнил все необходимые условия, чтобы заслужить звание прогрессиста, успевавшего за духом времени. Он «крестьян устроил», «ферму завел», читал, учился, просил совета образованных естественников относительно химических удобрений и их применения в земледелии и вообще, старался «стать в уровень с современными требованиями». Несмотря на все старания, он не добился цели. Суть его отношений с сыном отражает следующее признание: «я остался назади, он ушел вперед, и понять мы друг друга не можем». Дальнейший диалог содержит анализ причин сложившегося разлада и является своеобразной аргументацией в споре смолодыми. Отец спрашивал: «Да почему он ушел вперед?» и сам себе отвечал: «виноват нигилист этот, лекаришка, шарлатан». Объектом обсуждения становится нигилист. Само собой разумеется, что нигилист не мог быть признан Павлом Петровичем передовой силой: «Очень нужны нигилисты!». На это ироническое заключение Базаров ответил следующей репликой: «- Нужны они, или нет - не нам решать. Ведь и вы считаете себя не бесполезным»7. Таким образом, спор за первенство не завершился положительным заключением. Стороны остались при своих мнениях. Соглашению сторон помешали эмоции. На языковом уровне они проявились в нарушении Павлом Петровичем

7 Там же, т. III, с. 215. 
правил грамматики, а также в применении «военных метафор»: Павел Петрович спускается в гостиную для чаепития, но «уже готовый к бою». Он ждет предлога, чтобы «накинуться на врага» и т.п. В ситуации неразрешимости вопроса о передовой силе автор вывел героев за пределы семантического поля спора, переместив их в пространстве (молодые люди ушли, не завершив спора, а затем уехали в город, причем главный оппонент Базаров планирует не возвращаться назад в дом Кирсановых). Прекращение спора внушает мысль о тщетности надежд на деловую дискуссию как способ определения передовой силы, способной решить существенные проблемы времени.

Сам роман Omцы и дети вызвал острые споры на тему отношения автора к ведущим героям и передовой силе 8 . Они нашли своеобразное продолжение в произведениях, осмысляющих эпоху 1860-х годов и основанных на структурном принципе противопоставления старшего поколения умеренного в попытках преобразований, поколению молодому и радикальному, предлагавшему разрушение без программы перестройки.

В романе Дым, отразившем русскую жизнь времен Александра II, доминируют споры на политические темы, которые постепенно превращаются в ссоры всех со всеми. В нем изображены полемики трех главных сил: радикальной, либерально-западнической и консервативной. Их основанием послужила реальная полемика между Тургеневым и Герценом и публицистика писателя славянофила Ивана Аксакова9.

Радикальная русская молодежь, оказавшаяся в Гейдельберге по политическим причинам, считала всех других гейдельбергских эмигрантов врагами, что заранее исключало взаимное сближение. Сквозной темой споров являлась будущность России, в частности, вопросы женского труда, откупа, значения национальностей. Участвовавший в сходке у Губарева западник Потугин обратил внимание на высокую степень общности во взглядах спорщиков на будущее России и безуспешность споров на эту тему: «Жуют, жуют они этот несчастный вопрос, словно дети кусок гуммиластика: ни

8 Шире об этой полемике: B. Olaszek, Dymitr Pisariew. Wokót problemów pozytywizmu w Rosji, Wyd. Uniwersytetu Łódzkiego, Łódź 1997, c. 133-148.

9 См.: С.М. Аюпов, И.С. Аюпов, Романы И.С. Тургенева 1860-х годов в мире контекстов, РКО РУНМЦ МО РБ, Уфа 2010, с. 44-54. 
соку, ни толку» ${ }^{10}$. Спорщики щеголяли радикализмом и соперничали друг с другом, чтобы понравиться лидеру Губареву. Сам Губарев, от которого молодые почитатели ждали конкретного отношения к затронутым темам, отделывался общими фразами:

- Община... Понимаете ли вы? Это великое слово! Потом, что значат эти пожары... эти... эти правительственные меры против воскресных школ, читален, журналов? А несогласие крестьян подписывать уставные грамоты? И наконец, то, что происходит в Польше? Разве вы не видите, к чему это ведет? Разве вы не видите, что... мм... что нам... нам нужно теперь слиться с народом, узнать... узнать его мнение? ${ }^{11}$

Потугин считал Губарева и славянофилом, и демократом, и социалистом в одном лице и вступил с ним в заочную полемику. Во время визита у Литвинова он сначала охарактеризовал личные черты Губарева и других участников собрания, обнаружив в них ментальную черту предрасположенности к подчинению сильному лидеру и чрезмерную увлеченность идеями, например, идеей науки. Затем он стал полемизировать, но не с Губаревым, а с собирательным субъектом, то есть, как можно догадаться по содержанию реплик, со славянофилами. Он упрекнул их в ориентированности не на то, что есть, а на то, что будет, что можно предсказать, но чего нельзя проверить. Его главный тезис в полемике со славянофилами заключался в утверждении необходимости заимствований России от Запада. Ему возразил Литвинов, указав на угрозу утраты русскими национальной самобытности и на недостатки западноевропейской цивилизации как культурного образца. Потугин оказался глухим на возражения Литвинова. Он не сомневался в целесообразности западнического образца развития прогресса для России, даже за цену ошибок, выступал с авторитарных позиций и сам по ходу изложения своих взглядов обнаружил в себе черту бескомпромиссности, нерасположенности к диалогу: «Я, слава богу, перестал соображаться с понятиями, воззрениями, привычками человека, с которым беседую»12. Общественный вес его высказываний дополнительно

\footnotetext{
10 И.С. Тургенев, Собрание сочинений в двенадиати..., т. IV, с. 30.

11 Там же, с. 24.

12 Там же, с. 35.
} 
снижал стиль. Потугин вместо аргументов рассказывал анекдоты, вместо итогов приводил пословицы, благодаря чему его выводы приобрели характер общих изношенных истин.

Очередную группу спорящих представляли генералы. Предметом их прений являлась экономическая ситуация аристократии и дворянства после крестьянской реформы. Главными полемистами изображены два генерала: «снисходительный» и «раздражительный». Спор начался с описания плачевной ситуации, в которой оказалось дворянство после крестьянской реформы, разорявшееся, вынужденное продавать свои имения. «Снисходительный генерал» назвал пореформенную ситуацию «бездной» и постулировал отказ от реформ, переделку того, что уже сделано и возвращение к прежнему экономическому порядку: «надо переделать... да... переделать все сделанное».

Оппонентом генералов выступил Литвинов, который с позиции помещика-практика стал защищать историческое и политическое значение освободительного манифеста для крестьян и для России. Оно заключено в концепте «воля», обросшего мифическим значением. Литвинов, как человек сословно чужой генеральской среде, становится ее оппонентом и других вопросах. Очередная реплика «снисходительного генерала» была направлена именно ему. Генерал изложил положения своей программы:

Я сейчас сказал, что надобно совсем назад вернуться. Поймите меня. Я не враг так называемого прогресса; но все эти университеты да семинарии там, да народные училища, эти студенты, поповичи, разночинцы, вся эта мелюзга, [...] вот где нужно остановиться... и остановить 13 .

Одобрив технический прогресс, он отклонил его необходимые условия, а именно земскую и судебную реформы.

А прогресс... я собственно ничего не имею против прогресса. Не давайте нам только адвокатов, да присяжных, да земских каких-то чиновников, да дисциплины, дисциплины пуще всего не трогайте, а мосты, и набережные, и гошпитали вы можете строить, и улиц газом отчего не освещать?14

\footnotetext{
13 Там же, с. 67.

14 Там же, с. 68.
} 
Он утверждал программный тезис о необходимости привилегированного положения аристократии как единственной силы способной гарантировать общественный порядок. Все генеральское общество было согласно в необходимости защищать сословные интересы, но оно смущалось риторикой речи собеседника, употребляемыми им выражениями, например, «вежливо, но в зубы», содержащими квинтэссенцию программы излечения ситуации, предложенной «раздражительным генералом». Его речь была воспринята как «шалости и глупости озлобленного человека». Другие участники спора, например, князь Коко, защищая дворянские интересы, не приводил серьезных аргументов, а «тотчас принялся кричать и повторял круглые фразы: c’est absurde!...». Еще иной спорщик «не умел ни выслушивать, ни понимать возражения и так, несомненно, сам не ведал, в чем собственно состояла la question» ${ }^{15}$. Спор не кончился заключением. Его оборвали дамы, потребовав от мужчин прекращения прений. Предметно-смысловая сторона спора приобревшего вид светской беседы не была исчерпана, потому что участники в действительности не стремились найти решение затронутого ими вопроса.

Своеобразным резюме гейдельбергских споров стала концептуальная метафора «дым»:

\begin{abstract}
Вспомнилось ему многое, что с громом и треском совершилось на его глазах в последние годы... дым, шептал он, дым; вспомнились горячие споры, толки и крики у Губарева, у других, высоко- и низкопосавленных, передовых и отсталых, старых и молодых людей... дым, повторил он, дым и пар: вспомнился, наконец, и знаменитый пикник, вспомнились и другие суждения и речи других государственных людей - и даже все то, что проповедовал Потугин... дым, дым и больше ничего ${ }^{16}$.
\end{abstract}

Позиция автора в отношении к предмету и участникам споров обнаружена на событийном уровне. Потугин - porte parole автора - назначил Литвинова «русским деятелем», тружеником и пионером, при условии служения последним делу цивилизации. Предположение Потугина нашло подтверждение в дальнейшей судьбе Литвинова. Из всех гейдельбергских спорщиков

15 Там же, с. 107.

16 Там же, с. 175. 
только он став фермером, внедрил в хозяйственной практике положения творцов реформ.

На упрек Д. Писарева Тургеневу в предпочтении «прозаических фигур» писатель объяснил: «он дюжинный человек - и все тут» и добавил, что из уважения к этим работникам не стал их выносить на пьедестал ${ }^{17}$. В оценке Ю.В. Манна: «...по системе связей с другими персонажами и характеру авторской интроспекции Литвинов выдвигается на центральное место»18.

Фермерскому варианту перестройки русской жизни шестидесятых годов сопутствовало появление других проектов. Николай Чернышевский в романе Что делать? изобразил «добрых и умных людей», которые предложили проект швейной мастерской, основанный на кооперативных началах фурьеровской ассоциации. Хотя он родился не в спорах, а в голове Веры Павловны, следует о нем вспомнить как о своеобразном феномене. Экономический успех проекта, обоснованный в романе подробными бухгалтерскими данными, придал ему статус образцового решения социальных проблем. Проект организации швейных мастерских воспринимался современниками писателя как вполне реальное средство решения вопроса женского труда. Читательская рецепция свидетельствует о феномене стирания границ между литературной фикцией и жизнью. «Швейные машины» стали знаковыми в русской культуре. Еще более распознаваемым символом стал «хрустальный дворец» - воплощение мечты о будущем материальном и социальном устройстве мира. Он стал отправной точкой полемики других писателей с Чернышевским.

Достоевский в повести Записки из подполья прибег к реминисценции «хрустального дворца» как идеальной модели социального устройства. Подпольный человек оспорил научные основания разумной организации общества как якобы способные решить вопросы социальных противоречий и заложить основания новых экономических отношений.

Тогда-то - это все-таки говорите - настанут новые экономические отношения, совсем уж готовые и тоже вычисленные с математической точностью, так что в один миг исчезнут всевозможные вопросы, собственно

17 Письмо Д.И. Писареву от 4 июня 1867 г., [в:] И.С. Тургенев, Собрание сочинений в двенадияати..., т. XII, с. 376-377.

18 Ю.В. Манн, Тургенев и другие, Издательский центр Российского государственного гуманитарного университета, Москва 2008, с. 92. 
потому, что на них получатся всевозможные ответы. Тогда выстроится хрустальный дворец. Тогда... Ну, одним словом, тогда прилетит птица Каган $^{19}$.

В представлении героя реальность проекта равна появлению вещей птицы Каган, приносящей счастье, но которую, однако, нельзя увидеть, а тем более поймать. Посредством метафоры «птица Каган» Достоевский выразил свое недоверие к этому проекту и неодобрение его.

Государственное и общественное устройство России, взаимоотношения сословий помещиков и крестьян, общинное хозяйство и самоуправление, роль столичной и уездной администрации стали сквозными темами других полемических романов этого времени.

Алексей Писемский в романе Взбаламученное море поставил задачу обсудить положение дел в стране, изъявить собственную точку зрения на злободневные вопросы. Он на правах литературного героя стал соучастником споров на эти темы. Участие биографического автора, пусть введенного в текст по правилам литературной игры, является сигналом усиления полемичности. В заглавии и заголовках очередных частей и глав романа обращает внимание их тезисный характер: Акиии и покупка, Разные взгляды на общественное служение, Провинииальная гласность. В некоторых, например: Не любитель гласности, Хоть и прошлая, но не совсем милая картина обнаружена авторская оценка общественных явлений. Еще в других использованы пословицы, которые отражают итоги социальных поисков: Не всегда то найдешь, за чем пойдешь. Названные заголовки сами по себе осуществляют полемическую функцию. Изображенная в сюжетных ситуациях романа полемика развивает содержащиеся в заголовках положения.

В центр внимания автора Взбаламученного моря поставлена политическая тема отношения к реформаторскому курсу правления Александра II, путям русского прогресса, политической роли радикалов 1860-х годов, а также лондонских эмигрантов. Несомненно, главной темой, вызывающей споры, были последствия крестьянской реформы. Участниками спора на эту тему выступили: Бакланов - либерал 1840-х годов, социалист-радикал

19 Ф.М. Достоевский, Собрание сочинений в десяти томах, Государственное издательство Художественной литературы, Москва 1957, т. IV, с. 152. 
Валерьян Собакеев и не названный по имени помещик, который испытал на себе экономические результаты отмены крепостного права. Бакланов и помещик, исходя из сословных позиций, отрицательно оценили экономическое значение реформы. Они не верили в успех общинного хозяйства как альтернативного проекта для прежней экономической модели. Социалист Собакеев оценил реформу с политических позиций как акт исторической справедливости и компенсацию крестьянам за вековой гнет.

В очередной спор автор включил предводителя дворянства, что позволило в спорах о русских делах учесть вопрос дворянского самоуправления. Ведущей темой споров стали взаимоотношения дворян и крестьян после внедрения реформы. Бакланов, предводитель дворянства Варегин и помещики, оказавшись в конфликте с крестьянами, стали обсуждать вопрос обоснованности крестьянских претензий к помещикам, обвиняемых в несоблюдении постановлений царского манифеста. Историческим контекстом данной ситуации были подлинные бунты крестьян. Внимание спорщиков сосредоточено на аргументах предводителя дворянства, который защищал положения реформы: переход на наемный труд, замену ручного крестьянского труда машинным трудом как проверенные на практике способы решения противоречий интересов крестьян и помещиков и выхода дворян из кризисного экономического положения. Предложенные им методы ведения хозяйства встретились с резким порицанием со стороны участвовавшего в разговоре помещика. Оппонент оспорил пользу применяемых Варегиным методов, но не воспользовался в споре контраргументами, основанными на хозяйственной практике, а критиковал их по заранее предвзятой предпосылке. Он утверждал, что любые нововведения не могут принести положительных эффектов и являются бесполезными. Здесь выявлена психологическая черта спорщика как препятствие успешного завершения спора. Другим фактором провала дискуссии были сильные эмоции, мешавшие объективной оценке предмета обсуждения. В изображении писателя психология русского человека, стремящегося всему противоречить, все оспорить, часто становилась причиной недооценки практической стороны дела. Она отразилась на политизации языка общественного диалога.

В освещении Писемского критическое отношение к реформам сверху было свойственно социалистам-радикалам. Оно отражено в репликах в их адрес Бакланова, который с позиций человека 1840-х годов, стал 
беспокоиться за будущее России. В его оценке оно постепенно становилось делом «мальчишек»-радикалов, лозунги которых «ломать все под идею», быть гражданами, организовать фаланстеры» стали доминировать в общественном дискурсе. Неудивительно, что темой многих дискуссий стала потенциальная угроза для общества со стороны радикальных идеологий и средства противодействия их влиянию. Писатель стремился учесть в них голос разных общественных сил. В одной из таких дискуссий о русских делах приняли участие, кроме Бакланова, важный петербургский чиновник Ливанов, правовед-западник Юрасов и сам рассказчик, участвовавший в роли постороннего наблюдателя.

Спор затеял Бакланов. Он постулировал основание эстетического журнала как органа противодействия популярным в 1860-е годы идеям «крайнего реализма» 20 . Ливанов скептически высказался о перспективности программы Бакланова, направленной на формирование общественного мнения и ограничение влияния радикализма путем возобновления журнала эстетического направления ${ }^{21}$. Он признал проект несвоевременным. Сославшись на пример Европы, особенно Франции и Англии, он высказал мнение о неминуемости радикализации общественных настроений в России и на Запад как инкубатор радикальных идеологий.

Европа подкуривает настоящему распорядки!... Все очень хорошо понимают, что человеческие общества стоят на вулкане. Вот оттуда идут эти беспокойства и стремления к реформе, но враг идет, дудки! 22

Для ограничения их воздействия он постулировал умеренные демократические преобразования.

Третий участник спора правовед-западник не разделил опасений остальных субъектов дискуссии относительно привития радикализма в России. Он аргументировал свое мнение ссылкой на культурное отли-

20 Понятие «реализм» употреблено здесь в широком смысле жизненной установки, которым пользовались радикальные публицисты, например, Д. И. Писарев, автор трактата Реалисты (1864).

21 Писатель мог иметь в виду судьбы «Библиотеки для чтения» и свои в ней фельетоны.

22 А. Писемский, Взбаламученное море, [Электронный pecypc] az.lib.ru/p/ pisemskij_a/text_0130.shtml [15 октября 2015]. 
чие России от Европы («у нас все города, все жилища выстроены не так») и на исторический опыт присвоения русскими западных идей свободы и равенства. Важная тема значения западных влияний для современной политической обстановки была внезапно оборвана Ливановым, объявившим, что ему пора ехать к министру на раут. Пресловутую точку над «і» в этом споре поставили Бакланов и автор-повествователь, но она касалась не темы, а личности оппонента, названного «канальей». Очередной раз прием ad personam восторжествовал над приемом ad rem. У Бакланова осталось в памяти от спора впечатление многословия: «мириады фраз, которые раздавались около него в Петербурге - фраз, против которых он сначала ратовал, а потом и сам стал повторять их» 23 . Многословие - еще одна причина безуспешности русских споров.

Важным вопросом, затронутым в романе, стала организация политической оппозиции правительству. Ее инициаторы переехали за границу, сперва в Париж, затем в Лондон, с целью получить поддержку русских эмигрантов. Лондон как место встречи и политические эмигранты как советники отечественных оппозиционеров придали спору политический подтекст. Молодые радикалы, среди которых оказались как преданный идее материалист Собакеев, так и евреи-авантюристы братья Галкины, очутившись в обществе лондонских пропагандистов, единогласно отклонили возможность компромисса с властью. Законному способу упразднения рабства крестьян они предпочли силовое уничтожение привилегий помещиков, лишение их собственности. Спор не стал для эмиссаров платформой выработки общей политической стратегии, а подходящим случаем для того, чтобы показать свой радикализм. Хотя сам спор не разрешился конкретным заключением, то согласие героев провести в Россию пропагандистские материалы свидетельствует о последовательном выборе ими революционной тактики. Компрометация радикалов произошла вне ситуации спора, после их возвращения в Петербург. Автор-рассказчик назвал в финале радикалов обезьянами и фразерами, подражавшими лондонским наставникам и тем самым определил свое к ним отношение. Предвидя нападки со стороны потенциальных критиков романа, он открыл полемический сверхзамысел книги - ответ идейным противникам.

23 Там же. 
Напрасно враги наши, печатные и непечатные, силятся низвести наше повествование на степень бесцельного сборника разных пошлостей. Мы очень хорошо знаем, что они сердятся за нас за то, что мы рассказываем их болячки и бьем их по чувственному месту, между тем как их собственная совесть говорит за нас и тысячекратно повторяет им, что мы правы» 24 .

Иные задачи поставлены им в романе Люди сороковых годов. Неитральное заглавие указывает на время, определившее жизненные позиции поколения, которое проявило себя в реформах и преобразованиях Александра II. Писатель откликнулся в нем на злободневные вопросы русской пореформенной действительности, такие как: методы административного управления, результаты крестьянской реформы, община, свобода слова. В спорах на эти темы приняли участие губернатор Абреев и высокий чиновник Плавин, помещик-бытописатель Вихров, под именем которого скрывался сам Писемский, и передовая «развитая женщина» Мари. Основной тезис губернатора сводился к утверждению о том, что государство не подготовлено к проведению реформ.

Оппонентом губернатора в оценке административной политики правительства стал столичный чиновник Плавин. В спорах Абреева с Плавиным обсуждались противоречивые директивы административного правления, поступавшие к губернаторам от столичной министерской бюрократии. В оценке Абреева высшая власть рекомендовала губернаторам лицемерную тактику «железной руки, но мягкой перчатки». От губернатора она требовала, чтобы он не злоупотреблял властью, но держал бы всех в страхе и подчинении и одновременно заботился бы о престиже порученного ему ведомства. Абреев оценил, что подобные распоряжения не только не помогают реформированию страны, но способствуют хаосу.

Абреев расходился с Плавиным и в оценке результатов крестьянской реформы. Губернатор, сам помещик-аристократ, видел в реформе одни минусы: обеднение дворян, пьянство мужиков, упадок производства хлеба. Плавин с позиций либерала-бюрократа оспорил эту оценку как неверную, ссылаясь в своей аргументации на статистические данные, склоняющие к противоположным выводам.

\footnotetext{
24 А.Ф. Писемский, Взбаламученное море...
} 
В орбите критики Абреева оказался общественно важный проект общинного землевладения. Плавин стал его защищать, ссылаясь на историческую традицию общинного хозяйства в России. Тем самым он разделил точку зрения правительства на этот вопрос. Спору сопутствовали силные эмоции: Абреев: «усмехался», «возражал», «краснел в лице», говорил «прерывающимся от волнения голосом». Плавин - «замечал не без колкости», «прикрикивал», «повторял», говорил с оттенком насмешливости. Спор был оборван внезапным уходом одного из участников. Оппоненты так и не сблизились в оценке современного внутреннего устройства России и заявили о непримиримости в будущем. В оценке Вихрова - alter ego писателя, безуспешность диалога показывает, что Россия не усвоила демократических процедур и оставалась государством «все еще немножко азиатском». По его мнению надежда на успех скрывалась в сильной власти царя - «посланника и помазанника Божьего» и в общинном «хоровом начале». В обширной тираде публицистического характера герой развил эту типично славянофильскую идею. Его позиция объясняется сотрудничеством Писемского в славянофильском журнале «Заря» 25 .

Подобную Писемскому цель компрометации современных идейных врагов, их концепций и утверждения «хорового начала» поставил перед собой Николай Лесков в романе Некуда. Он сосредоточился на разоблачении социалистической утопии в виде производственной корпорации, изображенной Чернышевским в романе Что делать? «Хрустальному дворцу» Чернышевского соответствует в романе Некуда утопический проект «Дома Согласия», основанный на социалистических принципах коллективной собственности, разделения труда и капитала. Вокруг отдельных аспектов этого проекта устройства жизни, общественной и социальной, шли споры сторонников и противников. По замыслу организатора коммуны Петра Сергеевича Белоярцева, «Дом» должен был стать олицетворением мечты о социальном равенстве.

Этот один дом покажет, что нет нужды глотать свою плоть, что сильный и бессильный должны одинаково досыта наесться и вдоволь выспаться. Это дом... это... дедушка осмысленного русского быта, это дом ... какими

25 См.: С. Розанова, Комментарии, [в:] А.Ф. Писемский, Собрание сочинений в пяти томах, Изд. «Художественная литература», Москва 1983, т. IV, с. 306. 
должны быть и какими непременно будут все дома в мире: здесь все равны, все понесут поровну и никто судьбой не будет обижен» 26 .

Легко заметить, что предпосылкой проекта послужили положения экономической системы социализма, популяризуемые Чернышевским. Предметом постоянных дискуссий жильцов «Дома» являлся его устав. Обсуждались экономические правила существования коммуны, основанные на «гражданских принципах» имущественного равенства, но совещания никогда не кончались конкретными заключениями, а обидой части спорщиков. По словам повествователя, жильцы «не решив спорных вопросов, расходились по комнатам». Требование финансовых отчетов рядовых членов коммуны к лидеру наталкивалось на уловки с его стороны. В спорах по этому вопросу он вместо ответов по существу, выдумывал поддельные темы. Белоярцев был озабочен не успехом коммуны как социального проекта, а личным лидерством. Экономический принцип распределения труда и капитала, положенный в основу «Дома Согласия», оказался в реальных условиях утопическим, в чем его участники убедились не благодаря деловым аргументам, а личному опыту.

Во второй и третьей частях романа на первый план выдвинуты споры на тему необходимости уничтожения старых порядков, т.е., как легко догадаться, политического строя, власти и т.п. Спорщики разделены на радикалов (Арапов, Бычков) и умеренных прогрессистов (Розанов, Лобачевский). Они соревновались друг с другом за лидерство в общественной среде и проведении своих политических концепций. Суть спора радикалов с умеренными прогрессистами заключалась в разногласиях на тему способов преобразования России. Радикалы указывали на необходимость уничтожения существующего политического порядка во имя правды и мечтали о символическом пожаре Москвы и всей России. Прогрессисты полному разрушению предпочитали постепенные изменения, предлагая тактику «ладом делать». Обе стороны спора ссылались в своих репликах на «правду» как обоснование программ, но не выяснили, какой смысл вкладывали в это слово. Нечеткость понятий, употребляемых в споре, открывала простор для манипуляции.

26 Н.С. Лесков, Полное собрание сочинений, Изд. А.Ф. Маркса, Санкт-Петербург 1897, т. IV, с. 619. 
Мастерами манипуляции изображены в романе польские иезуиты, действующие в Москве. Они представлены соблазнителями русской идейной молодежи, убеждавшими ее в необходимости разрушения. Молодых радикалов занимала не выработка положительной программы, но поиски аргументов в пользу революционной тактики, за которыми они обращались к профессиональным революционерам в лице швейцарца Райнера и польским подпольщикам, сосредоточенным вокруг иезуита Ярошиньского. Одной из спорных тем стала возможность революции и участия в ней народных масс. Представления радикалов о настроениях масс были основаны на журнальных статьях «Колокола».Умеренные прогрессисты сбивали их аргументы в поддержку революции, ссылаясь на силу национальных чувств народа.

Автор романа разрешил спор на вербальном и на поведенческом уровне. Он изобразил сходку, в которой участвовали радикалы и польские подпольщики. Описание хода дискуссии позволило обнаружить механизмы вербальной манипуляции и ее последствия для радикализации русской мысли:

Начался либеральный разговор, в котором Ярошиньский мастерски облагал сомнениями всякую мысль о возможности революционного успеха, оставляя, однако, всегда незагороженным один какой- нибудь выход. Но зато выход этот, после высказанных сомнений Ярошиньского во всем прочем, незаметно становился таким ясным, что Арапов и Бычков вне себя хватались за него и начинали именно его отстаивать, уносясь, однако, каждый раз опрометчиво далее, чем следовало, и открывая вновь другие слабые стороны 27.

Иезуит Ярошиньский пользовался искусным риторическим приемом двусмысленности, чтобы спровоцировать молодых прогрессистов к откровенности. В итоге радикально настроенные спорщики стали принимать его положения за свои, развивать их, вплоть до заключения о необходимости революции и будущей организации общества на основаниях общей собственности и коллективизма. Вывод являлся не результатом убедительной аргументации, но эффектом успешной манипуляции опытного иезуита.

27 Тамже, с. 341. 
Заложенная автором цель компрометации радикалов и их наставников была вполне достигнута. Радикалы, поддавшиеся манипуляции поляка, действующие по эмоциям, неспособные трудиться и живущие за счет богатых товарищей, представлены лицами не заслуживающими доверия. Социалистические принципы имущественного равенства оказались также неосуществимыми.

Подводя итоги столкновения внутри «молодых сил» - радикалов и прогрессистов - автор оставил последнее слово за представителем последних. Розанов указал молодым «направление» выхода из тупика русской жизни. Оно заключалось в участии в «земском деле». В финале появляется новый положительный герой Лука Масленников - примерный семьянин и образцовый хозяин, призванием которого являлась служба обществу. Он арендовал помещичьи имения, заботился о крестьянах, открыл в своей деревне ремесленную школу и больницу. Эту образцовую модель русского хозяйства, успешно действующего в новых экономических условиях, Лесков противопоставил утопической петербургской коммуне. Заметим, что определение «дела», способного противостоять социалистической утопии, было не логическим заключением споров героев, а авторским словом, порученным герою - умеренному прогрессисту. Автор оправдал вмешательство публицистического слова в художественную ткань романа необходимостью противостоять современным журналистам, вводившим в заблуждение общественное мнение. В этом он усматривал значение полемического романа.

К хору полемистов, комментирующих веяния эпохи 1860-х годов, присоединился и Иван Гончаров. В романе Обрьв писателя волновал вопрос ведущей общественной силы - «нашей партии действия» в ситуации роста популярности социалистических идеологий. Писатель стремился к ее определению путем элиминации претендентов на это звание. Неудивительно, что спор стал в романе особо востребованным видом дискурса.

Внимание писателя сосредоточено на нигилистах как носителях общественного фермента. Характерно, что их разоблачение он начал с экономических вопросов. Это вызвано попытками отрицания социалистами права собственности как основания общественно-политической системы. Уже в первом разговоре Веры с Марком Волоховым тема собственности оказалась на первом плане. Волохов, пойманный на воровстве яблок из чужого сада, не стал оправдываться, а ссылаясь на афоризм французского соци- 
алиста П. Прудона «собственность - это кража», признал за собой право распоряжаться чужим добром и убеждал в этом Веру. Обмен мнениями на тему собственности кончился отклонением псевдонаучных аргументов Волохова.

О значении темы собственности для Гончарова свидетельствуют диалоги Татьяны Марковны Бережковой с Райским. Она выступила строгой защитницей собственности. Райский - наследник родового имения, которым она управляла, готов был передать собственность племянницам или вовсе передать имение в чужие руки или отдать его на благотворительные цели. Райского отличало характерное для многих дворян легкомысленное отношение к собственности. Он, как человек придерживающийся либеральных взглядов, положительно отнесся к планам освобождения крестьян. Помещица Бережкова, стоявшая на консервативных позициях, ответила отказом на предложение Райского отпустить на волю крестьян, ссылаясь в этом на их вековую неподготовленность к самостоятельности: «Избалованы, век - на готовом хлебе!» В оценке Райского управлялемое Бабушкой по крепостным правилам имение не отвечало современным стандартам: «Весь этот уголок, хозяйство с избами, мужиками, скотиной и живостью, терял колорит веселого и счастливого гнезда, а казался просто хлевом, и он бы давно уехал отсюда, если б... не Вера!»28

Замечание Райского актуализировало другую важную тему полемик 1860 -х годов, а именно тему способов и методов управления помещичьим хозяйством. Она не стала в романе самостоятельной темой, а была использована автором в функции аргумента в споре о достойном герое времени. Одним из критериев выбора такого героя стал вид деятельности и успехи на избранном поприще. В представлении Гончарова Россия конца 1860-х годов не нуждалась ни в Райском - художнике, ни в Волохове - политическом агитаторе. Им противопоставлен в романе человек, у которого другое поприще. Это - Иван Тушин, владелец образцового лесного хозяйства. Он сделал то, на что не были способны другие помещики: завел специализированное лесное хозяйство, основав его на наемном крестьянском труде, позаботился о социальной инфраструктуре, чем расположил к себе работников и сделал хозяйство доходным. Назначение Тушина представителем

28 И И.А. Гончаров, Собрание сочинений в восвми томах, т. V, Изд. «Художественная лигература», Москва 1979, с. 306. 
«партии действия» произошло, что особо подчеркнем, не в результате вербальных прений претендентов на это звание, но в итоге положительных оценок владельца Дымка окружающими его лицами - Верой, Бабушкой, Райским. В финале Татьяна Марковна доверила Тушину управление поместьем и прислугой, поручила ему ремонт дома. Можно предположить, что под управлением столь опытного менеджера, каким изображен Тушин, Малиновка преобразится в образцовое хозяйство. В выборе Бабушки отражена позиция автора в отношении будущего экономического устройства Малиновки-России. Выбор равнозначен с отклонением общественной роли пропагандиста Волохова и художника-дилетанта Райского. Такая расстановка акцентов стала началом дальнейших споров о передовом деятеле, возникших в среде радикальных критиков, которые не могли примириться с предложенным Гончаровым преимуществом прозаического хозяина над политическим радикалом.

Роман вызвал волну споров, которые показывают, как художественный дискурс давал начало публицистическому, а публицистический - художественному. В Предисловии кроману «Обрыв» писатель отклонил стереотип, согласно которому каждое новое поколение, вступая на историческое поприще, должно производить крутой переворот в государственной, общественной и частной жизни и призывал к союзу всех сил в деле обновления России. Он усматривал прогресс в сочетании материального благосостояния с нравственным возрождением, симбиозе науки с религией.

Не надо забывать, что развитием и упрочением реформ обуславливается не одно материальное благосостояние, но и нравственное воспитание и совершенствование народа, задача, к которой так усердно стремится новое поколение 29 .

Автор Предисловия... назвал пятнадцатилетие, начавшееся с 1855 года, «величайшей эпохой русской жизни», в которой старое и новое поколения должны объединить усилия и способствовать успеху реформ.

Если для Гончарова принципиальное значение имело сплочение общественных сил вокруг великого реформатора в лице Александра II, то для Достоевского значение имело нравственное обоснование общественной

29 Там же, с. 437. 
деятельности. Достоевский активно участвовал в общественной жизни $1860-80$-х годов и как журналист, и как писатель ${ }^{30}$. Хотя реальная действительность была для него лишь толчком для философских размышлений о человеке, то вокруг особо горячих тем и явлений, таких как справедливое социальное устройство, преступность и ее причины, либерализм и обуржуазивание России, характер прогресса - герои его романов вели бурные споры.

Внимание героев Преступления и наказания привлек вопрос значения социальных условий и последствий экономической трансформации для отдельного человека. Эта тема была предметом обсуждения на вечеринке у Порфирия Петровича. Исходной точкой спора стали воззрения социалистов на тему причин преступности, сведение их к несправедливому социальному устройству: «...преступление есть протест против ненормальности социального устройства - и только, и ничего больше, и никаких причин больше не допускается, - ничего!.. ${ }^{31}$ Эмоции спорящих были столь сильные, что еще на следующий день Разумихин не мог успокоиться. Он подчеркивал ограниченность социалистов и настаивал на значении нравственных факторов для справедливого социального устройства и для искоренения преступности.

Разумихин пытался опровергнуть коренной аргумент социалистов: «среда заела», которым они оправдывали преступления и которое стало ключевым словом демократической публицистики ${ }^{32}$ в попытках обоснования необходимости социальной перестройки общества. В изложении Разумихина в учении социалистов преувеличены социальные факторы и расчеты на безошибочность научного обоснования устройства общества и недоценены нравственные факторы. Для обоснования своей точки зрения он воспользовался примером фаланстеров, представляющих модель идеального социального устройства, предложенную Ш. Фурье и внедряемую в жизнь его идейными последователями. Разумихин в обширной

30 См.: В.А. Твардовская, Достоевский в общественной жизни России (1861-81), Изд. «Наука», Москва 1990.

31 Ф.М. Достоевский, Собрание сочинений в десяти..., т. V, с. 165.

32 Выражение «среда заела» могло быть почерпнуто Достоевским из текущей публицистики. В статье Николая Добролюбова Благонамеренность и деятельность (1860) оно является ключевым словом. 
реплике на воззрения социалистов настаивал на первостепенном значении человеческой натуры:

Фаланстера-то и готова, да натура-то у вас для фаланстеры еще не готова, жизни хочет, жизненного процесса еще не завершила, рано на кладбище! С одной логикой нельзя через натуру перескочить! Логика предугадает три случая, а их миллион! 33

Социалистические проекты фаланстеров признаны Разумихиным «головными», т.е. утопическими. «Математическая», научная организация жизни противопоставлена им «живому процессу жизни». Характерно, что для аргументации тезиса о несостоятельности научных принципов организации общества («С одной логикой нельзя через натуру перескочить!») использованы метафоры живой проиесс жизни, живая душа. Понятие живая жизнь считались синонимом жизни, в ее метафорическом библейском значении. Живому проиессужизни противопоставлена мертвечина, т.е. бездуховная жизнь. Итак, Разумихин отклонил аргументы о решающем значении социальных условий как причине зла. Хотя он приписал Порфирию Петровичу сочувствие воззрениям социалистов, но тут же отклонил этот упрек на том основании, что Порфирий Петрович не раз показал себя мастером «серьезно шутить», выдавать шутку за правду.

Реплики Разумихина отражают накал эмоций, накопившихся вокруг конкретных проектов переделки общества, каковыми были швейные кооперативы героини романа Что делать? или «Дом Согласия», организованный героями Некуда. Достоевский мыслил иначе чем Чернышевский. Он передал пальму первенства нравственному прогрессу как условию прогресса социального.

Эта позиция обнаруживается и в спорах на тему принципов поведения личности в социальной сфере. Примером может служить спор Раскольникова и его товарищей с Лужиным, оправдывавшим социальное неравенство утилитарной этикой, основанной на принципе индивидуального эгоизма. Лужин воспользовался аргументами, почерпнутыми из либеральной доктрины:

33 Ф.М. Достоевский, Собрание сочинений в десяти..., т. V, с. 166. 
Наука же говорит: возлюби, прежде всех, одного себя, ибо все на свете на личном интересе обосновано. [...] Экономическая же правда прибавляет, что чем более в обществе устроенных частных дел и, так сказать, целых кафтанов, тем более для него твердых оснований и тем более устраивается в нем и общее дело. Стало быть, приобретая единственно и исключительно себе, и именно тем самым приобретаю как бы и всем и веду к тому, чтобы ближний получил несколько более рваного кафтана и уже не от частных, единичных щедрот, а вследствие всеобщего преуспеяния ${ }^{34}$.

Очередной раз его оппонентом выступил Разумихин, который принял ссылку на авторитет экономистов-утилитаристов за риторический прием и «общее место» тогдашней публицистики, т.е. популярное учение, которое ему опротивело 35 . В дополнение Раскольников, приоткрыв перед товарищами закулисное отношение Лужина к женитьбе и к невесте, разоблачил его не просто как сторонника новых экономических правил, а пошлого эгоиста. Обмену мнениями сопутствовали сильные эмоции: Раскольников кричал, у него сверкали глаза, Лужин бледнел и закусывал губу. Спор превратился в ссору и кончился тем, что обиженный Лужин покинул комнату. Тема спора и его финал отражают интерес автора романа к злободневной теме вульгаризации «экономических начал» псевдолибералами ${ }^{36}$.

Интерес писателя к экономическим принципам, основанным на доктрине либерализма, объясняется его актуальностью в ситуации буржуазного развития, ослабления позиции дворян и попыток ее восстановления. Он нашел отражение и в романе Идиот.

В состоявшейся на террасе дачи Епанчиных светской беседе на тему русского либерализма приняли участие Евгений Павлович Радомский, князь Щ., Александра Епанчина и Мышкин. Главный тезис Радомского заключался в утверждении, что русский либерализм имеет антинациональный характер, что надо понимать как западный. Радомский, вопреки правилам

34 Там же, с. 156.

35 Можно догадаться, что он имел в виду труды Д.С. Милля и И. Бентама. Об английском влиянии на русскую общественную жизнь 1860-х гг., см.: Б.Ф. Егоров, Английский позитивизм и русская общественная жизнь 1680-х годов, [в:] Литература и искусство в системе культуры, ред. В.Б. Пиотровский, Изд. «Наука», Москва 1988, с. 420-427.

36 В.А. Твардовская, Достоевский в общественной..., с. 79. 
добросовестного спора, не объяснил значения понятий «либерал» и «либерализм» и пользовался ими в обыденном понимании. Он вывел социально-исторические корни либерализма от помещичьего и семинарского сословия, назвав социалистов «либералами из помещиков времен крепостного права». И либералов, и социалистов он упрекнул в отрыве от национальных корней.

У нас до сих пор либералы были только из двух слоев: прежнего помещичьего (упраздненного) и семинарского. А так как оба сословия обратились наконец в совершенные касты, в нечто совершенно от нации особливое, и чем дальше, тем больше, от поколения к поколению, то, стало быть, и все то, что они делали и делают, было совершенно не национальное ${ }^{37}$.

В подтексте высказывания обнаруживается критическое отношение к «западному» типу общественных преобразований и упрек в недооценке самобытных русских форм. Радомский произвольно поставил знак равенства между либералами, социалистами и консерваторами на том основании, что все они - «не русские»: «...и либералы у нас не русские, и консерваторы не русские, всё... И будьте уверены, что нация ничего не признает из того, что сделано помещиками и семинаристами, ни теперь, ни после...»38.

Отметим, что героем нарушен жанровый принцип тематического единства в споре - «одна тема - один спор». Благодаря отмеченной некорректности, можно заключить, что тема национализма вытеснила тему либерализма. Критика направлена Радомским не в адрес либерализма как такового, а специфически русского либерализма:

- Позвольте, - с жаром возражал Евгений Павлович, - я ничего и не говорю против либерализма. Либерализм не есть грех; это необходимая составная часть всего целого, которое без него распадется или замертвеет; либерализм имеет такое же право существовать, как и самый благонравный консерватизм; но я на русский либерализм нападаю, и опять-таки повторяю, что за то, собственно, и нападаю на него,

37 Ф.М. Достоевский, Собрание сочинений в десяти..., т. V, с. 377.

38 Там же, т. VI, с. 377. 
что русский либерал не есть русский либерал, а есть не русский либерал. Дайте мне русского либерала, и я его сейчас же при вас поцелую ${ }^{39}$.

Для остальных участников беседы наиболее уязвимым местом обширных тезисов Радомского оказался антинациональный характер русского либерализма, утверждение, что либерализм вырос из неодобрения русских порядков, оторвался от почвы и обособился в чистое отрицание. Князь Щ. стал возражать, оспоривая тот фрагмент высказываний Радомского, который касался отказа помещикам в национальных чувствах. Князя Щ. поддержала Александра Епанчина. Она сосредоточилась не на либерализме, а на защите национального начала, используя в качестве доказательства ссылку на русскую литературу. Радомский остался при своем мнении. Он поинтересовался отношением Мышкина к обсуждаемому вопросу, но у того не оказалось своего мнения. В этой ситуации Радомский стал выступать с позиций победителя в споре и превращать гипотезы в аксиомы.

Ну, так факт мой состоит в том, что русский либерализм не есть нападение на существующие порядки вещей, а есть нападение на самую сущность наших вещей, на самые вещи, а не на один только порядок, не на русские порядки, а на самую Россию. Мой либерал дошел до того, что отрицает самую Россию, то есть ненавидит и бьет свою мать. Каждый несчастный и неудачный русский факт возбуждает в нем смех и чуть не восторг. Он ненавидит народные обычаи, русскую историю, всё 40 .

Оппоненты в лицах князя Щ. и Александры сосредоточились на логической некорректности его аргументации. Князь Щ. принял их за шутку, Александра заметила, что он «частные случаи возвел в общее право» и пришел к ошибочным выводам. Мышкин тоже не соглашался с обобщениями Радомского. В дополнение Радомский - обличитель «русского либерализма» компрометирован служебной отставкой, вынужденной самоубийством дяди.

По мнению итальянского слависта Гуидо Капри, тема либерализма появилась в романе в результате анализа Достоевским пореформенных пере-

\footnotetext{
39 Там же.

40 Там же, с. 379.
} 
мен, наблюдений политических инициатив тверских либералов, влияния сочувствующих либерализму сотрудников журналов «Время» и «Эпоха» и была продиктована авторской концепцией обновления дворянства 41 .

На основании споров вокруг либерализма в буржуазном лужинском варианте и поместно-аристократическом варианте Радомского, можно сделать вывод о том, что Достоевский замечал значение либерализма в общественных переменах, но либералы не были той силой, которой писатель симпатизировал. То же самое можно сказать об его отношении к радикализму.

Очередной случай поспорить на тему радикализма представился на дне рождения князя Мышкина. Посетившая юбиляра молодежь (компания Бурдовского), а также Ганя и Птицин, стали спорить с Лебедевым, прослывшим в светской среде искусным толкователем Апокалипсиса, на тему оценки им положения России в «век пароходов и железных дорог» или, как он выразился, «наш век пороков и железных дорог». Лебедев, пользуясь символическим языком в описании действительности, связал цивилизационный, основанный на науке прогресс с разрушительными последствиями упадка звезды Полынь, замутившей «источники жизни». Рационально мыслящую молодежь возмущали оценки современности Лебедевым, раздражал его язык и кассандрические пророчества. Ганя Иволгин для опровержения утверждений Лебедева о пагубности технического прогресса применил иронию. Он сделал вид, что понял мысль Лебедева буквально и довел ее до абсурда. Лебедев в защиту своего тезиса еще расширил объект осуждения.

- Собственно одни железные дороги не замутят источников жизни, а все это в целом-сь проклято, все это настроение наших последних веков, в его общем целом, научном и практическом, может быть, и действительно проклято-с ${ }^{42}$.

Он вызывал противников - «людей науки, промышленности, ассоциаций, платы заработной и прочего» на своеобразную дуэль, поставив под сомнение их вклад в дело прогресса. Лебедев настаивал на необходимости

41 См.: Г. Капри, Достоевский-экономист. Очерки по социологии литературь, перевод из итал., Изд. Фаланстер, Москва 2012, с. 143-165.

42 Ф.М. Достоевский, Собрание сочинений в десяти..., т. VI, с. 422. 
религиозной основы общественной жизни. Как заметил Г.М. Фридлендер, писатель отозвался на спор Владимира Печерина с Александром Герценом о первенстве духовного или научного начала в прогрессе, отраженный в их переписке от 1853 года. Писатель разделил точку зрения романтика Печерина ${ }^{43}$. Птицин и Ганя в ответных репликах Лебедеву подчеркнули значение ассоциаций, солидарности и равновесия интересов как опорной точки «источников жизни». Аргументация Лебедева была названа Ипполитом «болтовней» и осмеяна молодыми. Это показывает разлад между поколениями, которые говорили на разных языках и никакого компромисса между ними не могло быть.

Пониманию сторон мешали свойственные им эмоции. Лебедев относился к оппонентам с презрением, оппоненты к нему - с пренебрежением. Несмотря на устремленность на компрометацию противника, участники заботились о корректности и соблюдении условий спора.

У нас, князь, полчаса тому составился уговор, чтобы не прерывать; чтобы не хохотать, покамест один говорит; чтоб ему свободно дали всё выразить, а потом уж пусть и атеисты, если хотят, возражают; мы генерала председателем посадили, вот-с! 44

\section{V.4. Отражение опыта российской действительности в спорах 1870-х годов}

1870-е годы - это время радикализации общественных настроений, возникновения революционно-террористических организаций - таких, как нелегальная «Народная расправа» во главе с Сергеем Нечаевым и народническая «Земля и воля», впоследствии разделившаяся на «Народную волю» и «Черный передел». Это - время двух волн «хождения в народ» (1874 и 1875 гг.), зарождения народных утопий, бурно развивающегося капитализма и споров о перспективности буржуазного развития, время работы представительных органов и русско-турецкой войны 1877-78 гг.

43 См. об этом: Г.М. Фридлендер, Примечания, [в:] Ф.М. Достоевский, Собрание сочинений в десяти..., т. VI, с. 711.

44 Ф.М. Достоевский, Собрание сочинений в десяти..., т. VI, с. 421. 
С текущей общественно-политической жизнью 1870-х годов связан сюжет романа Бесы. В романе представлены все главные социальные силы: аристократия, бюрократия, радикалы и мещанство. В нем затронуты вопросы социального устройства России, изображена борьба главных общественных сил: радикальных, расшатывающих все старое, и правительственных, сдерживающих разрушителей, характер и темпы прогресса. Вокруг этих вопросов прежде всего и шли споры героев романа. Их предлогом чаще всего были выходки Петра Верховенского.

Петр Верховенский задался целью произвести смуту, вызвать бунт, разрушить существующий порядок, а затем подумать, как бы на его развалинах «поставить строение каменное» исключительно своими силами. Верховенский являлся врагом государственного порядка, который он подрывал неуважением, интригами, мистификацией и шантажом. Его методы борьбы отражены в отношениях с губернатором Лембке. Верховенский в свободной беседе с губернатором критиковал власть, нагло нарушал светский этикет в обращении с ним, показывая этим дерзость «мальчишки». Губернатор, желая стать человеком середины - умеренным борцом с радикалами, с одной стороны, и скрытым оппозиционером по отношению к реформаторскому курсу правительства, с другой, затруднялся найти соответствующий способ осуществления своей философии управления. Примером невозможности достижения консенсуса представителя власти с радикалами является спор губернатора с Петром Верховенским, возникший вокруг содержания политических прокламаций. Губернатор считал содержащиеся в них обвинения в адрес власти необоснованными и преждевременными. Верховенский провокационно утверждал, что в прокламациях больше смысла, чем в канцелярских распоряжениях. Петр Степанович нарочно нарушал смысл реплик губернатора о недопустимости призыва к разрушению церквей, переиначивал их смысл и, таким образом, провоцировал собеседника к полной откровенности. Губернатор открыл ему секрет своих устремлений - усиление губернаторской власти для борьбы с радикалами, с одной стороны, и «республиканскими» идеями правительства, с другой. Под «республиканскими идеями» правительства он понимал новые учреждения, земские и судебные, к которым сам относился равнодушно, но готов был применительно к обстоятельствам как к их организации, так и к ликвидации. Иронический комментарий Петра Степановича к высказыванию губернатора: «а все-таки вы нам прокладываете дорогу и приготовляете 
наш успех» свидетельствует не о расположенности к сближению и соглашению сторон, а подчеркивает принадлежность к враждебному лагерю и планах борьбы. На просьбу губернатора к Верховенскому растолковать, кто такие «мы» и «вы», тот не ответил. Заключение Петра Степановича вызывало раздражение и гнев губернатора и привело его к мысли о необходимости притеснения своеволия молодых радикалов. На этом основании можно сделать вывод, что Достоевский критиковал и философию конформизма губернатора, и цинизм лидера радикальной молодежи и не находил выхода из тупиковой ситуации.

Споры в среде самой молодежи также не были продиктованы заботой об общем благе, будучи направлены не на поиск истины и идеала справедливого общественного устройства, а на победу над политическими противниками. В главе У наших изображен спор радикальной молодежи, по словам повествователя представляющей собою - «цвет самого яркокрасного либерализма». Темой обсуждения стало социальное устройство России. Спор проходил на сходке в доме Виргинских. Автором определен идейный облик отдельных участников, среди которых особой активностью отличались Шигалев, хромой учитель и Петр Верховенский. Предлогом к дискуссии послужил доклад Шигалева Изучение вопроса о социальном устройстве будущего общества, которым заменится настоящее, в котором он переосмыслил утопические проекты Платона, Руссо, Фурье и Чернышевского. Уязвимой точкой доклада, вокруг которой вспыхнул спор, было разделение докладчиком человечества на две неравные половины и постулат наделения одной десятой свободой и безграничными правами при одновременном превращении остальных девяти десятых в стадо. Постулат Шигалева поддержал хромой учитель, сославшись на авторитет утопических социалистов Фурье, Кадета и Прудона. Оказавшись на сходке радикалов, он не посмел отказаться от авторитетных идейных учителей. Припомним, что суть примененного им риторического приема, известного в логике под названием argumentum ad verecundiam, состоит в допустимости, что авторитет, опираясь на корректные предпосылки, может ошибаться в выводах. В спор вмешался Верховенский, который воспользовавшись ссылкой на те же авторитеты, что и Шигалев, стал подрывать современное значение социалистических учений и указывать на бесплодность шигалевского проекта. Хромой учитель в ответ оспорил замыслы авторов распространяемых по городу прокламаций иностранного происхождения, призывавших 
к организации в России «кучек с целью всеобщего разрушения», признав их не менее утопическими, чем шигалевские идеи. Возник очередной спорный вопрос о перспективности социалистической пропаганды в России. Верховенский успешно переключил внимание остальных субъектов спора с вопроса о надежности средств политической пропаганды на личность учителя - единственного критически рассуждающего оппонента, приписав ему черты носителя несвоевременных эстетических идей сороковых годов. Затем он заставил его ответить на конкретный вопрос о готовности стать членом пятерки. Учитель ответил утвердительно, но с оговоркой. Верховенский не допускал никаких оговорок, усматривая в них слабость русских дискуссий. Противопоставив «разговорам» «скорые решения», он, в сущности, уменьшил значение диалога и отклонил спор как путь к выработке политической истины: «Я согласен совершенно, что либерально и красноречиво болтать чрезвычайно приятно, а действовать немного кусается...» 45 Верховенский потребовал от участников встречи однозначного определения своих позиций, но вопрос для референдума сформулировал на метафорическом языке, назвав тактику постепенного преобразования общества «черепашьим ходом в болоте», а радикального - «ходом на парах через болото». Формулировка вопроса с использованием метафор вместо однозначных определений стала видом вербальной манипуляции, благодаря которому вопрос остался неясным для участников, исключал возможность рациональной реакции и вызвал сильные эмоции. Растерянность отдельных участников относительно предмета, по которому они голосовали, показала, что победила не логика, а коллективная психология толпы: «так как уж все, то и я со всеми». «Психология толпы» не раз бывала причиной провала «русских споров», отсутствия рациональных выводов.

Дальнейший ход спора у Виргинских еще отчетливее обнаружил силу механизмов политического воздействия. Вопрос социального устройства, принципы которого остались для участников туманными, заменен в нем присягой лояльности кружку и подчиненностью демоничному предводителю. Кружковая солидарность как объединяющая идея предсказывает дальнейшую политизацию общественного дискурса, в котором диалогическое высказывание будет заменено авторитарной речью политического лидера.

45 Там же, т. VII, с. 428. 
Откликом Тургенева на радикализацию общественной жизни 1870-х годов стал роман Hoвb, в котором писатель изобразил проходившие на родине споры политически поляризованных групп - народовольческой молодежи, дворянских ретроградов, либералов, постепеновцев. Они имели еще более принципиальный и резкий характер, чем это было в предыдущих романах писателя и порою превращались в вербальные схватки. Это заметно в поведении субъектов споров, их подходе к затрагиваемым темам, эмоционально насыщенном тоне высказываний.

В романе изображены три главные общественные силы: консерваторы в лице Калломейцева, либералы-помещики в лице Сипягина, радикалы в лицах Нежданова и Маркелова. Особое место выделено Соломину. Все они участвовали в спорах на старые темы: реформы Александра II, социальные идеи, программы революционного движения и постепеновства.

Калломейцев в разговоре с Сипягиной раскритиковал реформы, особенно земскую. Он высказался против земства как органа ослабляющего администрацию и местное управление, чем вызвал возражение Сипягиной, заподозрившей его в оппозиции правительству. Калломейцев отклонил это предположение и определил себя принципиальным противником любых реформ, нарушающих дворянские привилегии, врагом как либералов, так и радикалов. Тема нашла продолжение в споре Калломейцева с Сипягиным, касавшимся злободневных вопросов:

Речь шла о земстве, о губернаторе, о дорожной повинности, о выкупных сделках, об общих петербургских и московских знакомых, о только что входившем в силу лицее Каткова, о трудности достать рабочих, о штрафах и потравах, а также о Бисмарке, о войне шестьдесят шестого года и о Наполеоне III, которого Калломейцев назвал молодцом 46 .

Целью спора не была выработка конкретных мер улучшения ситуации, а определение личных идейных позиций. Калломейцев показал себя консерватором, приверженцем старых порядков, Сипягин - либералом. Сипягина поддержала его жена, недоумевавшая, как это Калломейцев, человек образованный и молодой, может придерживаться «застарелой рутины». Она обратила аргументы Калломейцева в шутку, благодаря чему

46 И.С. Тургенев, Собрание сочинений в двенадиати..., т. IV, с. 233-234. 
спор приобрел игровой, салонный характер. Сославшись на высказанную мужем характеристику Нежданова, она легкомысленно причислила последнего к лицам симпатизирующим либералам и к противникам Калломейцева.

Очередной спор имел более четкий политический характер и касался деятельности радикалов - заграничных «якобинцев и революционеров», а также «доморощенных нигилистов и социалистов». Сторонами выступили Калломейцев и Нежданов, арбитрами - Сипягин с женой. Калломейцев в филиппике, направленной против радикалов, высказал мнение, что надо уничтожить всех радикалов: «он изъявил желание раздробить, превратить в прах всех тех, которые сопротивляются - чему бы то ни было!» 47 и адресовал свое высказывание Нежданову как их представителю. Он обосновал свое предложение ссылкой на авторитет своего друга и единомышленника Владислава, писателя и обличителя нигилистов ${ }^{48}$. Нежданов в ответ Калломейцеву стал защищать надежды, принципы и идеалы молодежи. Калломейцев вместо контраргументов стал ему грубить, чем нарушил правила светского спора. В этой ситуации Нежданов вместо инвективной лексики в адрес оппонента прибег к опровержению авторитета Владислава, назвав последнего клевретом, т.е. приспешником власти, не брезгающим неблаговидными средствами в борьбе с противниками и, соответственно, приписал черты клеврета Калломейцеву. Таким образом, меняется настоящий предмет спора: вопрос об отношении к радикалам как политической силе заменяется вопросом о чертах оппонента.

Для определения личных черт спорщиков значение приобретает риторика спора. По словам рассказчика, Нежданов придерживался правил спора, возражал, но не обижал противника. Калломейцев же переиначивал смысл его слов, прибегал к пререканиям, бранил. Спору сопутствовали сильные эмоции: Калломейцев «задыхался от негодования», «заикался от бешенства...», «грубил». Нежданов «вспыхнул», заговорил жестами: «ударил ладонью», «пожал плечами». Для описания спора автор применил «военные метафоры»: назвав спор схваткой, а его участников - врагами.

47 Там же, с. 281.

48 Прототипом Владислава был публицист М.Н. Катков. См.: А.И. Батюто, Примечания, [в:] И.С. Тургенев, Собрание сочинений в двенадиати..., т. IV, c. 517. 
В споре, который произошел за столом у Сипягиных, Маркелов с Неждановым устремлены не на диалог с политическими противниками, а на разрешение конфликтов при помощи силы. Маркелов изъявил желание «расшибить в прах всю его (Калломецева - Б.О.) нахальную физиономию» 49 , но тут же вспомнил о более важной задаче - борьбе с целым дворянским сословием: «Теперь не время сердиться на дураков за то, что они говорят глупые слова; теперь время мешать им глупые дела делать» 50 .

В роли арбитров в состоявшемся обмене мнениями выступил Сипягин, который призвал участников к примирению: «- Под моим кровом, [...] нет ни якобинцев, ни клевретов, а есть только добросовестные люди, которые однажды поняв друг друга, непременно кончат тем, что подадут друг другу руки!» 51

Противники умолкли, но не помирились и продолжали испытывать друг к другу ненависть. По словам повествователя, сам арбитр руководствовался не гражданским долгом примирения разногласий, а желанием порисоваться, показать личную высокую культуру.

Поведение участников спора подтверждает наш исходный тезис, что ни консерваторы, ни радикалы, ни либералы не стремились к выработке политического компромисса, а были заинтересованы в утверждении личной привилегированной общественной позиции.

Автор романа, как внимательный наблюдатель русской жизни, выдвинул на сцену новую силу - постепеновцев. Он изобразил Соломина - «дельного труженика на ниве малых дел». Соломин был приглашен к Сипягиным в качестве советника по делу управления фабрикой. Как сословно чужой человек он стал оппонентом аристократа Калломейцева. Непосредственным предлогом к спору послужило отрицательное мнение Соломина о дворянах в роли промышленников. Его темой стали коммерческие таланты и действия дворян. Соломин критиковал дворян-промышленников, указывая на эксплуататорский характер их деятельности.

Концессию на железную дорогу получить, банк завести, льготу какую себе выпросить или там что-нибудь в таком роде - никто на это как

\footnotetext{
49 И.С. Тургенев, Собрание сочинений в двенадиати..., т. IV, с. 253.

50 Там же.

51 Там же, с. 283.
} 
дворяне! Большие капиталы составляют. Я именно на это намекал - вот когда вы изволили рассердиться 52 .

Калломейцев не нашел подходящего контраргумента. Он с позиции представителя привилегированного сословия упрекнул собеседника в резкости суждений и перевел спор в идеологический план. Сипягин тоже высказался против мнения Соломина о деловой неприспособленности дворян. Сделав вид, что он согласен с доводами Соломина, в действительности стал защищать дворян:

Но теперь, после всех благодетельных реформ, в наш промышленный век, почему же дворяне не могут обратить свое внимание, свои способности, наконец, на подобные предприятия? [...] Не страдают же они недостатком образованности - и даже можно с удостоверительностью утверждать, что они в некотором роде представители просвещения и прогресса! 53

Реплику Сипягина отличает риторический пафос. Желательное он принимал за должное. Дискуссия о современном положении дворянства была затем расширена на другие сословия - купцов и крестьян. Позиции субъектов спора в оценке их значения еще больше разошлись. В этой ситуации Сипягин прибег к приему диверсии в споре и произнес длинную речь, в которой похвалил консерваторов, одобрил либералов, превознес народ, выразил полное доверие правительству и в заключение провозгласил тост за союз «Религии, Земледелия и Промышленности» под эгидой мудрой и снисходительной власти. Хотя речь содержала призыв к союзу, он был лишь уловкой, рассчитанной на то, чтобы вызвать расположение Соломина и поощрить его стать директором нерентабельного завода. В подборе аргументов и в стиле выступления, насыщенного народными пословицами и изречениями, Сипягин ориентировался на Соломина - «русского человека - из народа», но и на себя. Он хотел доказать, «что и он сам - не только русский человек, но «русак» и близко знаком с самой сутью народной жизни!». Компромиссные акценты не обольстили Соломина, который не

52 Там же, с. 353.

53 Там же, с. 354. 
принял предложения Сипягина, зато рассердили Калломейцева. Поведение в споре Сипягина показывает, что в действительности на первый план он ставил не народные, а личные интересы. Очередной раз узколичные интересы доминировали над общественными.

Самыми принципиальными противниками существуюего порядка изображены в романе молодые радикалы. В их среде на тайных ночных заседаниях шли бурные споры на тему настоящего и будущего России.

Паклин скоро понял, что от него требовалось, и начал все бранить (оно же для него было делом подходящим) - все и всех: и консерваторов, и либералов, и чиновников, и адвокатов, и администраторов, и помещиков, и земцев, и думцев, и Москву, и Петербург! 54

В гостиной купца Голушкина молодые люди спорили все со всеми и обо всем. Инициатором спора на тему планов действий молодых подпольщиков в сложившейся ситуации стал купец Голушкин. Для описания окружающей действительности - городских порядков, власти, чиновников, автор романа воспользовался концептуальной метафорой «гниль». Участники встречи стали искать и обсуждать оздоровительные методы борьбы со злом. Паклин предложил полумеры, Голушкин - полное разрушение. Нежданов постулировал оставить слова и перейти к делу. Только Соломин внимательно слушал других, говорил мало, не навязывал свое мнение, но логически аргументировал. Он предложил эволюционную тактику - «выжидать да подвигать дело вперед». Его предложение постепенных преобразований снизу вызвало возражение со стороны Маркелова, заявившего: «Нам не нужно постепеновцев» и со стороны Голушкина с компанией гостейединомышленников. Раздался гам голосов и разлился поток слов-ключей: «прогресс, правительство, литература; податный вопрос, церковный вопрос, женский вопрос, судебный вопрос; классицизм, реализм, нигилизм, коммунизм; интернационал, клерикал, либерал, капитал; администрация, организация и даже кристаллизация ${ }^{55}$. Накопление слов-ключей надо отнести к эристическим приемам. Из-за обилия слов-лозунгов их смысл понизился, а спор не принес решения. Они не только не помогли, а даже

\footnotetext{
54 Там же, с. 323.

55 Там же, с. 325.
} 
помешали найти ответ на вопрос о тактике борьбы с общественным злом: полумерах или полном разрушении. Участники сходки, оказавшись на улице не знали куда и за кем следовать. На вопрос: «куда же мы теперь?», только Соломин дал однозначный ответ: «на фабрику».

Определения «гам голосов», «поток слов» отражают хаос «русских споров». Споры тургеневских героев показали, какой является Россия, но не принесли ответа на вопрос, какой она должна быть. Положительными героями изображены не мастера полемики, а сдержанные в словах, но сильные в делах персонажи.

В полемику об облике России 1870-х годов включился и Лев Толстой. Писателя беспокоила послереформенная ситуация, особенно экономическое положение дворян и их отношения с крестьянами после отмены крепостного права, роль установленных царскими указами новых учреждений, таких как местное самоуправление, суд присяжных и т.д. Писатель воспринял системные реформы Александра II как своеобразный государственный переворот. Данный тезис подтверждают слова героя романа Анна Каренина Константина Левина: «... но у нас теперь, когда все это переворотилось и только укладывается, вопрос о том, как уложатся эти условия, есть только один важный вопрос в России» 56.

Писатель ставил героев в ситуации, позволившие оценить значение и последствия реформ для отдельной личности. Спорщиками на эти темы выступили герои романа - теоретики и практики, сторонники либерального и консервативного направлений. Важной темой стала экономическая ситуация крестьян, новые трудовые отношения помещиков и крестьян. Самым активным участником споров на экономические темы являлся Константин Левин, но он, заметим, изображен не субъектом спора и его зачинщиком, а оппонентом. Субъектами в затеянных спорах выступали самые разнообразные лица: либеральный чиновник Стива Облонский, брат Левина - народник-радикал Николай Левин, ученый либерал Сергей Кознышев, земский деятель Николай Свяжский, московский публицист Песцов и др. Отметим, что исходная сюжетная презентация спорщиков принадлежит всезнающему повествователю, слово которого предшествовало прениям спорщиков и имело существенное значение в определении хода и итогов спора и выявлении авторской позиции.

56 Л.Н. Толстой, Собрание сочинений в двадиати..., т. VIII, с. 361. 
В предварительной характеристике участников спора говорится, что Стива Облонский по своей эпикурейской натуре не сильно защищал либеральные взгляды, а скорее воспринимал либерализм как стиль поведения, подходящий к образу жизни, который он вел, т.е. он представлен несерьезным партнером в споре.

Если и была причина, почему он предпочитал либеральное направление консервативному, какого держались тоже многие из его круга, то это произошло не оттого, чтоб он находил либеральное направление более разумным, но потому, что оно подходило ближе к его образу жизни ${ }^{57}$.

Совсем другим спорщиком изображен Сергей Кознышев. По ходу его характеристики несколько раз подчеркнуты методический складума, ясность и отчетливость выражений, даже изящество дикции Кознышева. Для него общественные и экономические преобразования, которыми жила страна, были чисто теоретическими вопросами. Он избегал споров на конкретные темы, но живо интересовался самоуправлением, выборами уездных предводителей, деятельностью земства, общиной, славянским вопросом.

Свяжский назван повествователем «чрезвычайно либеральным земским деятелем». Он с позиций западника резко критиковал русские порядки, правительство, цивилизованную запоздалость страны. Русских мужиков он ставил по развитию между обезьяной и человеком, являлся сторонником ограничения привилегий духовенства и сокращения церковных приходов.

Песцов отрекомендован повествователем как видный представитель московской интеллигенции, либерал, не предрасположенный к жесткому соблюдению либеральных принципов, светский человек. Либеральные взгляды были для него видом маски, под которой скрывался характер конформиста, считавшего либерализм модным течением.

Вышеназванные герои сходились в осуждении всего русского, т.е. были космополитами. Судя по объему характеристик отдельных героев, больше внимания автор уделял тем героям, которые своими взглядами и поведением вызывали наибольшие разногласия. Их оппонентом, активным или пассивным, чаще всего бывал Константин Левин.

57 Там же, с. 13. 
По сравнению с либералами Константин Левин изображен человеком, окончательно не определившимся, ищущим своего пути. Левин являлся выпускником университета, естественником по образованию, помещиком по призванию и занятиям и как таковой, был серьезным оппонентом спорщиков в лицах ученого, общественного деятеля, высокопоставленного государственного чиновника.

Одной из важных тем, вызывавших споры, были новые учреждения и порядки, возникшие в процессе внедрения реформ. Как было упомянуто выше, они велись с четких политических позиций. В разговоре братьев Левиных Николаем были раскритикованы новые учреждения, мировые судьи, земство. Константин разделял это мнение, но по идеологическим причинам не желал быть союзником активного народника-радикала, занимавшегося революционной пропагандой в деревне, скрытой под видом артельной деятельности. При очередной встрече братья дискутировали о новых принципах организации трудовых отношений с крестьянами, которые Николай отождествил с коммунистическими принципами, заимствованными и неприменимыми к русским условиям. Константин, парируя, отрекся от общности с коммунизмом и изложил суть разницы в следующих словах: «- Да я тебе говорю, что это не имеет ничего общего. Они (коммунисты - Б.О.) отвергают справедливость собственности, капитала, наследственности, а я, не отрицая этого главного стимула [...] хочу только регулировать труд» 58 .

Константин умеренный, Николай - радикальный во взглядах. Константин искал способ примирить противоположные интересы помещиков и крестьян. Николай назвал его поиски лицемерием, желанием «не просто эксплуатировать мужиков, а с идеею». В очередной реплике он упрекнул брата в самолюбии и отсутствии убеждений. На этом основании можно предположить, что аргументация Николая была направлена на идейное разоблачение Константина Левина. Константин обиделся, спор по делу превратился в ссору по самолюбию и кончился отъездом Николая и депрессивным настроением Константина. Дело, по которому они спорили, осталось нерешенным.

Иной ход имел спор Константина с его старшим братом по матери Сергеем Кознышевым. Темой стал вопрос уездного самоуправления, земства

58 Там же, с. 385. 
и участия Константина в его работе. Левин, опираясь на личный опыт, оспорил смысл деятельности земства, уездных судов и больниц. Кознышев оценил отказ брата участвовать в системных преобразованиях сверху как своеобразный саботаж. Он считал брата совиновником утраченных исторических шансов, открывшихся перед Россией, благодаря реформам Александра II. В ответ Левин воспользовался образным сравнением русских реформ с насаждениями березок в Троицин день и желанием создать таким образом видимость, что они - «лес, который сам вырос в Европе». Он сам не намерен был участвовать в этой подделке, т.е. заботиться об успехе реформ. Завершение спора не равнозначно окончательной победе Кознышева над Левиным. В очередном споре по тем же вопросам разногласия между братьями обнаружились еще отчетливее. Кознышев пришел к выводу, что скептицизм Константина в отношении реформ, его коренной аргумент обусловленности общественной активности личной пользой (Константин отказывался от дела организации медицинских пунктов, суда и народных школ на том основании, что он лично не намерен ими пользоваться) является неприемлемым, т.е. он «или не имеет смысла, или имеет очень дурной смысл». Отказ Левина участвовать в работе новых послереформенных учреждений являлся не только милой причудой, но и проявлением свойственного русскому человеку равнодушия к преобразованиям сверху. Позиция неучастия Левина в государственных проектах предшествует антигосударственным трактатам Толстого.

Константин был убежден, что Кознышев не понял его отношения к народу и к новым общественным установлениям, только не знал почему. У него возникли три предположения на тему причин непонимания: «не умел сказать ясно то, что хотел, потому ли, что брат не хотел, или потому, что не мог его понять» 59 . Попытка разрешения спора на следующий день кончилась неудачей. Хотя Кознышев разобрался, в чем состояло разногласие, Константин уже не помнил предмета спора и заключил его следующим выводом: «Разумеется, и я прав, и он прав, и все прекрасно»60. Парадоксальность данного заключения подрывает целесообразность спора как способа выявления истины.

59 Там же, с. 274.

60 Там же. 
На основании поведения сторон в споре в сознании читателя закрепился портрет Левина-ретрограда и Сергея Кознышева - ученого-прогрессиста. Создается впечатление, что победителем в споре стал Кознышев, но повествователь, анализируя причины поражения Левина, переставил акцент с аргументов на эристические приемы. Сергей вел спор согласно правилам логики, избегал уловок, Константин же плохо владел искусством спора - «был уличаем в противоречии самому себе», реагировал эмоционально: «объяснял горячась», «все более горячась» и «говорил так, как будто прорвало плотину его слов». Левина смутило требование брата придерживаться строгой логики в споре. Он заранее знал, что «...ему будет доказано, что он говорит пустяки, не имеющие никакого смысла. Как это будет доказано, он не знал, но знал, что это, несомненно, логически ему будет доказано, и он ждал этого доказательства» 61.

Для определения позиции персонажей в споре значение имеет замечание повествователя, что Сергея Кознышева волновал не сам предмет спора, но увлекало собственное мастерство вести спор. Он не находил удовольствия в споре с Левиным, потому что слишком легко разбивал его. В понимании Кознышева спор являлся упражнением ума, возможностью проявить себя. Обращает внимание сравнение спора с шахматной игрой. В оценке повествователя Кознышев «не больше к сердцу принимал вопросы об общем благе и о бессмертии души, чем о шахматной партии или об остроумном устройстве новой машины» 62 . Припомним, что подобная ассоциация спора с шахматной игрой появилась в романе Omuъь и детu. Сравнение спора с игрой и развлечением отражает авторские сомнение в значении спора как способа выработки консенсуса в важных общественных вопросах.

Очередной спор на тему положения дворян и крестьян в новых экономических условиях и новых методов ведения хозяйства, а также практического значения органов местного управления разыгрался в доме богатого земского деятеля Свяжского. В нем приняли участие хозяин и «практики» в лице Левина и местного помещика. Зачинщиком спора стал помещик, который раскритиковал все нововведения и высказался за преимущество патриархального хозяйства перед рациональным хозяйством, какое вел

61 Там же, с. 265.

62 Там же. 
Свяжский. Помещик заступился за крепостную систему. Сам Свяжский молчал, но можно сказать, что его молчанием распорядился повествователь, приписывая ему космополитические взгляды убежденного проевропейского либерала, пренебрегавшего всем, что русское и предпочитавшего все европейское. Свяжский вежливо, но сдержанно отнесся к гостям и к предмету спора. Он оборвал прения в самом разгаре, предложив гостям выпить простоквашу и показав этим, что ему было все равно, к чему приведет их рассуждение. По словам повествователя Свяжского, интересовал единственно процесс рассуждения, т.е., риторика спора. При построении ситуации автор воспользовался эристическим приемом подмены аргумента ad rem аргументом ad personam. По ходу сюжета читатель узнает, что жизнь Свяжского представляла собой ряд парадоксов. Предполагалось, что этот образцовый либерал - милый человек, но «дурак или дрянь». Эта уничижительная оценка тут же была оспорена повествователем, который в другом месте подчеркнул его черты ума, образованность, честность и доброту. Для контраста оппонент Свяжского назван повествователем человеком «озлобленным», терявшим самообладание, делавшим в своих рассуждениях необоснованные обобщения, т.е. интеллектуально ограниченным.

Внимание повествователя сосредоточено на реакции Левина на реплики участников спора. Левина не интересовали общие фразы Свяжского, но сильно волновали замечания помещика. Он соглашался с исходными, основанными на личном опыте тезисами помещика, но не разделил его выводов о преимуществе крепостной системы. В конечном итоге преимущество в споре осталось не на стороне идеолога-теоретика Свяжского, а на стороне помещиков-практиков. Хотя спор не кончился совместным заключением, то принес положительный результат, а именно спровоцировал Левина к новым поискам справедливых принципов ведения хозяйства.

Опыт анализа споров на общественные темы в романе Анна Каренина позволяет сделать заключение, что Толстой замечая недостатки его участников, все таки отметил положительную роль спора как стимула дальнейших поисков решения общественных проблем. Позиция Левина в спорах на тему правительственных реформ и его попытки нравственного обоснования экономических отношений являются отражением авторских взглядов на вопросы справедливого общественного устройства России. Они получили общественный резонанс и нашли воплощение в культурных скитах, возникавших в 1880-е годы в среде приверженцев толстовского учения. 


\section{V.5. Споры вокруг общественных программ последней четверти века}

В 1880-е годы общественно-политическая ситуация сильно изменилась в результате террористического акта убийства Александра II. Правление Александра III началось с «Распоряжения о мерах к охранению государственного порядка и общественного спокойствия и приведения определенных местностей империи в состояние усиленной охраны» (1881). Его последствием был государственный контроль на всех уровнях жизни общества, не способствовавший атмосфере свободного диалога и спора. В экономическом плане фактом общественной жизни стал капитализм, вокруг отношения к которому шли споры публицистов разных направлений. Писатели откликнулись на них, но только в 1890-е годы. К горячим темам, вызывавшим споры, принадлежало отношение к народничеству и толстовству.

Заметное в 1880-е годы измельчание тематики споров (обсуждались частные вопросы и конкретные мероприятия в масштабах не целой страны, а «малой родины») связано, как думается, с жанровой трансформацией литературы, расцветом мелких эпических жанров, в которых не хватало места для спора как первичного жанра. Кроме того, в начале 1880-х годов самые крупные писатели - такие, как Тургенев и Гончаров, по возрасту или по состоянию здоровья допевали свои senilia, или, как Достоевский и Толстой, говорили проповедническим голосом.

Политическая тема отошла у Достоевского на второй план. В Братьях Карамазовых - «романе-синтезе» и «эпосе современной России»63, действие относится к шестидесятым годам, но приметы жизни более характерны для восьмидесятых годов. Споры имеют в нем философски-нравственный и идеологический характер. Значение политических преобразований обсуждается не в спорах, оно отражено в судьбах персонажей, например, в роли судов нового типа в жизни Мити Карамазова. Полемический темперамент Достоевского нашел свое выражение в Дневнике писателя. Писатель был убежден в преимуществе нравственного прогресса над общественными преобразованиями, в чем мы имели возможность убедиться по ходу анализа споров в его романах. В Речи о Пушкине Достоевский также выдвинул тезис о бесполезности политических перемен и о нравственно-

63 Определения - заглавия глав книги Л. Гроссмана Путь Достоевского (1924). 
сти как двигателе прогресса. Его тезисы вызвали полемику со стороны либералов и народников ${ }^{64}$, которая проходила на страницах «Вестника Европы», «Молвы» и «Дела».

Представление о том, кто с кем и о чем спорил в последние десятилетия девятнадцатого века, можно получить и благодаря рассказам Чехова. Так в рассказе Дом с мезонином (1896) предметом споров стало земство и деятельность земцев, «малые дела» и народное образование, отношение интеллигенции к народу. Заспорили Лида Волчанинова, увлекшаяся «малыми делами», ее сосед-помещик, которого она хотела привлечь к делу и художник, случайно оказавшийся в русской глубинке. Лида, занимаясь «малыми делами», активно участвовала в общественной работе в пользу народа. Предлогом разговоров на общественные темы послужили мелкие эпизоды повседневной усадебной жизни. Темой спора Лиды с художником стал смысл «малых дел», которыми она занималась, и участие в них деревенской интеллигенции. В качестве аргументов Лида воспользовалась примерами, почерпнутыми из окружающей реальной жизни, доказывающими необходимость участия интеллигенции в просвещении народа и в его лечении. Она усматривала спасение деревни и развитие народа в организации деревенских школ и фельдшерских пунктов. Художник видел улучшение жизни народа в освобождении от физического труда и создании благоприятных условий для духовного развития. Выше задачи народного обучения он ставил необходимость университетского образования интеллигенции:

Призвание всякого человека в духовной деятельности - в постоянном искании правды и смысла жизни. Сделайте же для них ненужным грубый животный труд. Дайте им почувствовать себя на свободе и тогда увидите, какая в сущности насмешка эти книжки и аптечки. Раз человек сознает свое истинное призвание, то удовлетворять его могут только религия, науки, искусства, а не эти пустяки 65 .

Третий субъект спора - сосед спорил «с явным желанием казаться умным и передовым человеком», а в действительности, «скучно, вяло и длинно».

64 См. об этом: В.А. Твардовская, Достоевский в общественной..., с. 219-311.

65 А.П. Чехов, Полное собрание сочинений и писем в тридиати томах. Сочинения, Изд. «Наука», Москва 1985, т. IX, с. 185. 
Легко заметить, что он ничего не внес в решение вопросов, которые волновали Лиду и художника, а побуждения, которыми он руководствовался, указывают на личные причины участия в споре. Каждый из участников спора говорил о своем, не рассчитывая на взаимопонимание. Лида в споре с художником вела себя вызывающе, провоцировала его к возражениям и одновременно открыто презирала своего оппонента, насмешливо улыбалась, заслоняла лицо газетой, притворялась, что его не слушает. Художник раздражался ее отношением: «... по ее тону было заметно, что мои рассуждения она считает ничтожными и презирает их» 66 . Спор был оборван Лидой, уверенной в невозможности убедить оппонента, не разделявшего образа ее мыслей: «Перестанем же спорить, мы никогда не споемся...». Это заключение не только свидетельствует о трудностях межчеловеческой коммуникации, о чем писали Анна Енджейкевич и Андрей Степанов 67, но и о бесперспективности спора как способа выработки общественной программы, под которой могла бы подписаться вся интеллигенция. С точки зрения результатов спор героев можно причислить к «пустым спорам». Большинство исследователей рассказа Дом с мезонином, интерпретируя идейный смысл произведения считают, что симпатия автора находится на стороне художника 68 . В защиту главной героини обратим внимание, что ее увлеченность культуртрегерскими задачами демонстрирует идеализм родовую черту русской интеллигенции.

О поисках идейно настроенной интеллигенцией поприща для деятельности писал Чехов в повести Моя жизнь. Молодое поколение в лице Мисаила Полознева, доктора Благово, Маши Должиковой было недовольно своей жизнью и хотело жить «по-иному». Оно стремилось найти общественное течение, к которому стоило бы примкнуть. Поводом к спору послужило мнение доктора Благово утверждавшего, что такого течения в России нет, так как и нет «интеллигентных тружеников», которых выдумала «новая литература». Свой тезис он аргументировал следующим образом:

66 Там же, с. 185.

67 Anna Jędrzejkiewicz, Opowiadania Antoniego Czechowa - studia nad porozumiewaniem się ludzi, Wyd. „Studia Rossica”, Warszawa 2000, s. 129-138; А.Д. Степанов, Проблемы коммуникации у Чехова..., гл. VI.

68 В.М. Радионова, Нравственные и художественные искания А.П. Чехова 90-х - начала 900-х годов, Прометей, Москва 1994, с. 113. 
Культурная жизнь у нас еще не начиналась. Та же дикость, то же сплошное хамство, то же ничтожество, что и пятьсот лет тому назад. Течения, веяния. Но ведь все это мелко, мизерабельно, притянуто к пошлым, грошовым интересикам - и неужели в них можно видеть что-нибудь серьезное? 69

Мещанским идеалам он противопоставил сциентистскую программу: «Учиться нам нужно, учиться и учиться, а с глубокими общественными течениями погодим: мы еще не доросли до них и, по совести, ничего в них не понимаем» 70 . Слова героя свидетельствуют о предпочтении им умственного прогресса как предварительного условия социального прогресса. Мария Викторовна, которая затронула горячую тему об отсутствии вдохновляющих общественных течений, не ответила доктору, ограничившись замечанием, что надо жить по-иному. Неопределенность ее представлений об «ином» позволяет сделать вывод, что их спор о характере прогресса и воодушевляющих общественных течениях был бесплодным рассуждением, типичным для тогдашней интеллигенции. С проблемой поисков общественного поприща связана дальнейшая судьба героини.

Другой, не менее важной темой повести было участие интеллигенции в культуртрегерской программе «малых дел». Мария Викторовна Должикова увлеклась опрощенцем Мисаилом и «малыми делами». Она вышла замуж, покинула отцовский дом, переселилась в деревню, где построила школу для крестьянских детей. В доме молодоженов шли споры на тему целесообразности «малых дел» на фоне неблагодарности мужиков. Маша считала адресатом программы ближайшее окружение и ожидала немедленных результатов окультуривания. Участие Маши в «малых делах» оказалось временным увлечением, а она сама стала «попутчицей» популярных в девяностые годы программ. Данный вывод подтверждают слова Мисаила: «идеи и модное умственное движение служили ей для наслаждения, разнообразили ей жизнь».

Иначе думал Доктор Благово. Он видел в «малых делах» вклад интеллигенции в культурный прогресс, результаты которого обнаружатся в далеком будущем. В оценке Мисаила выводы Благово были типичной интеллигентской риторикой, потому что сам он сомневался в своих словах. При

69 А.П. Чехов, Полное собрание сочинений..., т. IX, с. 230.

70 Там же. 
столкновении с прозаическими проблемами - поведением мужиков, хозяйственными заботами Мисаила, доктор раздражался и переставал спорить. Поведение Благово отражает типичную для русского интеллигента расположенность к тому, чтобы поговорить о делах, поспорить о них, но уклониться от конкретных действий. Эта черта не уменьшает значения самого спора. Мисаил отметил, что, несмотря на то, что в полемике с Благово он обыкновенно оставался при своем мнении, спор с этим умным человеком способствовал его интеллектуальному развитию и выработке твердых убеждений.

Наряду с либерально-народническими и толстовскими общественными программами, направленными деревне, интеллигенцию занимали вопросы политические. Об этом свидетельствует семейная хроника Евгения Чирикова Отчий дом (1929-1931), отразившая русскую жизнь с 1880 по 1906 год. Хроника определена эпопеей, «воссоздающей панораму общественной, политической и духовной жизни России последних десятилетий XIX и начала XX столетия»71. С этой точки зрения, она является ценным источником знаний о проблемах, волновавших общество. Действие происходит в волжских городах Симбирске и Алатыре, а также в обеих русских столицах и за границей. В хронике, что связано с временем и местом действия, появились реальные исторические лица - такие, как Владимир Ульянов, Надежда Крупская, Максим Горький. Автор Семейной хроники, исходя с позиций свидетеля изображенных в хронике событий, воспользовался при передаче содержания споров приемами несобственно-прямой речи.

Произведение содержит историю трех братьев - членов семьи аристократов Кудышевых. Они олицетворяли различные направления общественно-политической жизни: консервативное дворянство (мать семейства), либеральное народничество (старший брат Павел Николаевич), радикальное народничество с уклоном в марксизм (средний брат Дмитрий Николаевич), толстовство и различные сектантские уклоны (самый младший брат Григорий Николаевич). В освещении автора хроники патриархальная модель жизни в дворянском гнезде Кудышевых постепенно разрушалась. Между сыновьями и матерью обнаружился и постоянно углублялся воз-

71 М.В. Михайлова, А.В. Назарова, Россия как отчий дом, [в:] Е. Чириков, Отчий дом. Семейная хроника, Изд. Эллис Лак, Москва 2010, с. 6. 
растной раздел во мнениях и отношении к жизни. Мать придерживалась дворянских этических правил, дети нарушали их и отказывались от их применения в жизни. Сыновья упрекали мать в непонимании «духа времени» и характера общественных перемен. Мать отмечала поколенческий разлад, констатируя: «На разных языках общаемся». Авторитет матери, ее слова постепенно утрачивали свое значение, а принципиальные вопросы обсуждались только в среде детей, их единомышленников и врагов.

Предметом споров на этапе юности героев было отношение к тактике революционной борьбы радикальных народников и толстовским идеалам непротивления злу насилием как альтернативным концепциям преобразования общества. Идейно настроенные интеллигенты, какими были братья Кудышевы, расходились в отношении к вышеупомянутым концепциям. У них были разные представления об идеальном общественном устройстве России и способах его осуществления. Оно воплощено в идеологеме «Царствие Божие на земле». У братьев, как было сказано, были разные представления о самом «Царствии». Хотя все они говорили о правде как его основе, но на самом деле, они говорили о ее разновидностях: «правдеистине», «правде-справедливости», «правде Божией». Дмитрий усматривал путь к Царствию Божиему на земле во всемирной революции, Григорий в нравственном совершенствовании на евангельских основаниях, Павел в «совершенном государстве, в котором интересы личности находятся в полной гармонии с интересами государства». Неудивительно, что при столь разных идейно-политических установках на идеальное государственное устройство между братьями возникали бурные споры. Обстановка споров и сопутствующие им эмоции отражены в метафорических определениях: атака, бой, победа, «петушиный задор» и т.п.

Предлоги к спору бывали самые разные, например, современная политически ангажированная литература - роман Бесы Достоевского и философские трактаты Л. Толстого. Один из спорщиков, ссылаясь на биографию автора Бесов, отказал писателю в праве оценивать сложные общественные явления политического характера. По словам повествователя: «одни называли Достоевского писателем гениальным, другие - вредным ретроградом, третьи - пасквилянтом, оболгавшим всех передовых людей. Защищали немногие...» 72 .

72 Е.Н. Чириков, Отчий дом. Семейная..., с. 207. 
В контексте тогдашней борьбы за власть, народнических попыток силового свержения самодержавия, особо уязвимым оказался для спорщиков толстовский призыв к непротивлению злу насилием. В оценке толстовского постулата они ссылались на реальный опыт политической борьбы: средний брат, несмотря на отказ от насилия, был подвергнут тюремному заключению и ссылке. На этом основании либерально настроенный Павел убеждал братьев в непригодности толстовского учения в условиях обострения общественных противоречий. Толстовское учение защищал самый младший брат, симпатизирующий доктрине яснополянского мыслителя. Затронутая в споре тема непротивления злу насилием принадлежит к «русским вопросам», никогда не завершавшимся однозначным заключением. И в данный раз спор был оборван приездом нового гостя.

Споры в среде никудышевской молодежи вызывались и конкретными событиями, например, убийством крестьянами студента-волонтера, принявшего участие в борьбе с холерой, постигшей южные русские губернии. Темой спора стала оценка поведения народа в отношении интеллигенции, непонимание им смысла интеллигентской жертвы, а также роль интеллигенции в подготовке к крестьянским бунтам и реакция правительства на случаи крестьянских преступлений. Исходной точкой спора оказались «холерные бунты» крестьян, проходившие с избиением врачей, фельдшеров и санитаров. За констатацией фактов последовал вопрос об ответственности за эти бунты, вокруг которого возник очередной спор. Собравшиеся в доме Кудышевых представители местной администрации считали виновником бунтов народническую интеллигенцию, издавна подстрекавшую крестьян. Бывшие народники в лице хозяина Павла Кудышева излагали ответственность на государство, отказавшее громадной части населения в гражданских правах. Его аргументация имела отчетливо политический характер. Герой утверждал, что Россия - государство без граждан и как таковая - антигосударственная страна. По его мнению, необходимость признания гражданских прав для народа должна быть очевидной для политиков и представителей местной власти. По мнению Павла Кудышева, причиной применения насилия как способа разрешения конфликтов являлось порабощение народа, поэтому вину за убийство студента либерал Кудышев возложил на государство. Оппонентом Павла Николаевича выступил представитель местной власти, но вместо контраргументов он заступился за государя императора и в знак протеста покинул компанию. 
В качестве аргумента в споре была использована басня Ивана Крылова Ле$б е д b$, Щука и Рак, но участники спора вместо присвоения поучительного характера морали о необходимости совместных действий, сосредоточились на личной идентификации с басенными персонажами. В результате, к разногласиям во мнениях прибавилась личная обида спорщиков друг на друга. На основании данного эпизода становится понятным, что в условиях тогдашней России диалог, а тем более политический консенсус, были невозможными.

По ходу сюжета меняется жанровое оформление изложения разногласий героев на злободневные темы. Спор уступает место обширным отступлениям публицистического характера, содержащим анализ актуальной политической ситуации и авторские оценки идейных позиций героев. Их сигналом являются часто появляющиеся в повествовании идеологизмы: эволюция, культурная работа, которым сопутствуют противоположные по значению лексемы: революция, террор и пропаганда ${ }^{73}$. Постепенно в частных беседах начинают доминировать политические темы: «Наше русское несчастье: нет умеренного прогрессивного центра. На одном конце революционеры, утописты, фанатики, на другом - закоснелые в старине бегемоты столбового дворянства, а в середине - пусто» 74 .

Идейная расстановка оппонентов в спорах о том, кто является ведущей политической силой, основана на поколенческой оппозиции «отцов и детей». Для «отцов», выросших в атмосфере народовольческой революционной борьбы, идеалы «детей», увлеченных учением Л. Н. Толстого, изложенным в трактате Исповедь и статье В чем моя вера? были неприемлемыми. Павел Кудышев принципиально не согласен с идеями их автора, которые определил «толстовской ересью».

Существенное значение в спорах имело отношение к мужику, который в оценке «старших» был «природным социалистом», «младших» - «носителем и хранителем Божьей правды». Правильность оценки политической позиции мужика в условиях конца века имела значение для определения дальнейшего пути развития России, революционного или нравственного.

73 О явлении идеологизации языка см: J. Wierzbiński, Языковой монументализм в России ХХ века (Диахроническая экспликация научных парадигм), Wydawnictwo UŁ, Łódź 2012.

74 Е.Н. Чириков, Отчий дом. Семейная..., с. 165. 
В оценке «отцов» при толстовском способе борьбы с социальным злом мысль о революции стала утопической, что с точки зрения воспитанного на идеалах революционного народничества Павла Кудышева противоречило характеру русского интеллигента:

...какая же революция, когда проповедуется непротивление злу насилием? Какая же революция бывает без насилия? И какой русский интеллигент, спросим, перефразируя Гоголя, не любит быстрой революции? 75

О накале общественных настроений свидетельствуют быстро меняющиеся объекты обсуждений.Тема идейной настроенности мужика сменяется вопросом о политической необходимости превращения его в пролетариат. Авторами идеи о необходимости замены крестьянства пролетариатом как движущей силой социального прогресса названы в хронике эмигранты - бывшие народники, члены «Черного передела», которые обратились к марксизму. Популяризаторами их концепций изображены в хронике радикальные студенты. По словам рассказчика, «новая ересь» - идейно-политическая пропаганда социал-демократов, стала объектом критики местной интеллигенции - гостей братьев Кудышевых. Среди них оказались самые разные люди: студент-социалист, земской врач, мировой посредник, названный типичным «шестидесятником», сын местного предпринимателя. Спорщиков привлекала перспектива «умных разговоров» как формы интересного проведения времени в провинциальном захолустье, но не только. Их занимала свойственная «русским мальчикам» мечта о подвиге, ответ на вопрос «кем нам быть?» и «что делать?», к какой примкнуть политической силе. Первостепенное значение приобретало представление о подвиге, который мог быть трудом на ниве «малых дел» или революционным действием. Сомнения идейно настроенной молодежи не разрешены. Спор о подвиге был оборван приглашением к обеду: «- Господа! Бросьте толочь воду в ступе! Обедать зовут!». Заметим, что спор назван «толчением воды в ступе», т.е. занятием бесполезным, тратой времени. Тема была продолжена в послеобеденной беседе за столом, но не была завершена выводом по причине приезда неожиданного гостя.

75 Там же, с. 204. 
По нашим наблюдениям, героев Отчего дома постепенно стали занимать узко политические темы. Это вызвано появлением и ростом в 1900-е годы значения новых политических сил - социал-демократов и марксистов.

В Никудышевке, дворянском гнезде Кудышевых, появился «левый флигель», своеобразный партийный клуб, сплачивающий героев, симпатизирующих марксизму. В его центре оказалась Марья Ивановна, жена Дмитрия Кудышева, сосланного в Сибирь за симпатии к марксизму. Споры во флигеле велись в условиях конспирации. Одна из таких встреч превратилась в политическое заседание с участием Надежды Крупской в роли эмиссара «главной швейцарской квартиры», т.е. пребывающего в эмиграции Ленина. Интересно проследить ее ход с точки зрения специфики политического спора.

Участниками встречи стала местная радикальная интеллигенция и «солидные люди» в лице эсера Скворешникова и адвоката Пенхежевского, известного защитника политических заключенных. Крупская выступила с докладом - толкованием политических взглядов «центра», в котором проводила тезис о вреде «экономизма» 76 и перспективности революционной борьбы пролетариата. Доклад был прочитан в тоне, исключавшем возражения со стороны остальных участников встречи. Он был принят молчанием, недоумением и вызвал возражения единственно со стороны Скворешникова. Оппонент в качестве аргумента сослался на программу марксистского органа «Рабочее дело», утверждавшего необходимость политической борьбы только в ситуации экономической борьбы и упрекнул Ленина в чисто политических расчетах: «Если у Плеханова с товарищами была экономика без политики, то ваш гениальный супруг Владимир Ильич готовит нам политику без экономики, а вместо социальной революции - бунт!»77 Дальше спорщик не стал доказывать преимущество экономизма, но сосредоточился на критике личности Ленина - автора революционной тактики в политической борьбе, упрекнув его в искажении мысли Маркса («подло насилует Маркса, делая из него прикладное искусство - делать революцию!»). Критика Ульянова была воспринята Крупской за личное оскорбление.

76 Экономизм - одно из течений социал-демократов, выдвигавших постулат борьбы за улучшение экономической ситуации рабочих.

77 Е.Н. Чириков, Отчий дом. Семейная..., с. 378. 
Основная тема была оставлена, а внимание спорщиков привлекли эпитеты в адрес Ленина. Эту простую уловку в споре - перемену темы, умело использовал адвокат Пенхержевский - мастер в риторическом искусстве спора. Он успешно манипулировал смыслами спорных выражений и сумел усмирить негодование Крупской, обиженной критикой ее мужа.

Спор был продолжен молодыми социал-революционерами, сосредоточившимися на политических противоречиях - ленинских планах проведения всемирной пролетарской революции и их собственных планах ограничения борьбы до осуществления экономических задач, повышения материального благополучия масс и т.п. В ответ Крупская доктринерски заявила преимущество интернациональных целей над узко русскими: «Вы стараетесь свергнуть самодержавие, чтобы на его месте устроить буржуазный парламент, а мы сметем самодержавие на пути к всемирной революции...»78 С этой реплики Крупской круг обсуждаемых вопросов расширился на вопросы национальное/интернациональное. Стороны уточнили значение этих ключевых понятий, а затем стали обсуждать их преимущества. Интернациональные идеи ленинского толка оказались чуждыми для русских социал-революционеров. В постулате всемирной революции они разгадали политические планы Ленина по созыву Третьего Интернационала под его личным руководством. Дальнейший ход дискуссии показал, что для ее участников первостепенное значение имело лидерство в политической борьбе. На это указывает поведение в споре Скворешникова: в начале главного оппонента Ленина, а затем его союзника в планах проведения мировой революции. Он сосредоточен не на обосновании концепции политической борьбы, а на убеждении присутствующих в том, что он предложил ее раньше Ленина: «Я писал об этом еще в 80-х годах». Приведенные слова убеждают в том, что важнее дела (выбора направления политической борьбы) было соревнование с Лениным за лидерство. Личный интерес показать себя перед другими доминировал над политической прагматикой.

Объектом дальнейших споров героев становятся реальная политика, поведение отдельных членов правительства и советников царя, определяющих направление политических преобразований, примеры которых неоднократно появлялись на страницах хроники.

78 Там же, с. 381. 
Подходящим случаем поспорить на политические темы стала свадьба дочери главного героя. Собравшиеся гости, противники и сторонники министра Витте - советника Николая II, стали осуждать его политический курс. Непосредственным толчком к спору послужил тост в честь министра, содержание которого не все присутствующие одобрили. Прозвучали аргументы за и против. Противниками политики министра оказались собравшиеся на свадьбе местные земские деятели, воспитанные в духе народнической идеологии, аристократы и дворяне, сторонниками - интеллигенты, симпатизирующие марксизму, купцы, предприниматели и представители местной власти. По мнению первых, министр программно обезземелил крестьян, разрушил общину и искусственно насаждал в России капитализм и пролетариат. По мнению дворян, министр вел направленную против них политику. В оценке рассказчика - постороннего наблюдателя русской жизни, анализирующего состояние умов в провинции, разногласия вокруг политики министра показали, что тогдашняя Россия находилась в состоянии политического хаоса.

И вот в неожиданной словесной битве, закипевшей около имени Витте, как в малом осколке зеркала, отразился весь хаос в умах и душах культурных людей, который царил теперь во всей взбаламученной России. Правда, это отражение получило карикатурный облик, ибо воевали подвыпившие представители всех классов, сословий и власти, но тем выпуклее и ярче предстал перед нами общий развал в умах и чувствах... ${ }^{79}$

Обе группы имели в виду не общее добро, а осуществление сословных и партийных интересов. Споры названы «словесной битвой» и были направлены не на достижение компромисса, а на углубление царившего хаоса. Обращает на себя внимание употребленная автором метафора «взбаламученная Россия», по аналогии отсылающая читателя к диагнозу общественной ситуации, поставленному в 1860 -е годы Писемским в романе Взбаламученное море.

С точки зрения представления о споре как пути к истине, к лучшему общественно-политическому строю, можно сказать, что в изображении

79 Там же, с. 508. 
Чирикова русские споры вели никуда. К такому выводу склоняет название места действия - Никудышевка, которое ассоциируется с идейным смыслом заглавия романа Лескова Некуда. «Отчий дом», за судьбы которого беспокоился автор, предоставлен всяким случайностям и в итоге оказался в состоянии хаоса и безначалия. По замечанию одного из спорщиков, генерала Замураева - столпа самодержавного порядка, завершившая спор драка- это «предвкушение будущего русского парламента», с чем с перспективы наблюдателя политической жизни XXI века нельзя не согласиться.

\section{V.6. Споры на политические темы начала $\mathrm{XX}$ века}

Первое десятилетие XX века отличают качественные изменения в общественно-политической жизни России. Чириков в своей семейной хронике отметил значение обновления внутренней политики министрами Николая II - Петром Дмитриевичем Святополком-Мирским и Сергеем Юльевичем Витте, в частности их проектов указа о выборах и конституции и значение самого Манифеста о созыве представительного органа - Государственной думы от 6 августа 1905 года. Вокруг этих актов правительственной политики шла борьба политических партий и их лидеров.

Интеллигентские русские споры по частным домам, ночные беседы по флигелям, журфиксы вроде «буржуазных пирогов», о которых повествовалось в хронике, уступили место выступлениям на партийных съездах и уличных демонстрациях. В финале произведения Чирикова доминируют не споры вокруг конституции и парламентарный дискурс, а политические речи. Спорщиков заменяют ораторы, выступавшие от имени коллектива. Например, в день объявления конституции «взлохмаченный оратор провозглашал под памятником Пушкину директивы вождя партии: «Мы не продадим товарищей за эту конституцию! Только в борьбе обретем мы право свое! Да здравствует вооруженное восстание!» 80.

Отклонение конституции и предпочтение борьбы парламентарным формам решения политических вопросов - сигнал неприятия споров в русской политической культуре.

80 Там же, с. 675. 
Ход споров вокруг конституции в провинции показывает неподготовленность к гражданской жизни и низкий уровень политической культуры. Во главе сторонников конституции оказался либерал Павел Кудышев, мечтавший стать профессиональным политиком. Политические симпатии в симбирской провинции разделялись между сторонниками самодержавия, названными «монархистами» и политическими радикалами - «республиканцами», которые спорили друг с другом, но их споры не приводили, по словам повествователя, ни к каким результатам, не завершались существенными заключениями, а обидными для обеих сторон «шуточками». «- Кто прав, рассудит история, - говорил Павел Николаевич. Не будем судить и мы, кто ближе к истине в этих спорах интеллигенции, завоевавшей, наконец, право принять участие в судьбах своего народа»81. За успехом интеллигенции в завевании демократических прав к политическим спорам как форме общественного диалога и гласности, не последовали реальные результаты в виде важных решений.

На этапе ускоренной политизации жизни интеллигентские «русские споры» вытесняются другим первичным речевым жанром, а именно партийной речью. Интересно проследить ее риторические приемы на примере выступлений Павла Кудышева и Владимира Ленина.

Кудышев, претендовавший на роль депутата в Думу от конституционно-демократической партии, считал себя обязанным разъяснить смысл политических событий представителям местной интеллигенции. Горячей темой была тогда оценка политических результатов московского восстания 1905 года. В состоявшейся беседе-споре с местными радикалами и либералами докладчик признал незаконной революционную тактику социал-революционеров в ситуации существования в стране парламента и оправдал принятые правительством меры. Одобряя силовые методы правительства в отношении к революционерам, он сослался в качестве аргумента на аналогию с мерами, применяемыми в профессиональной практике своего оппонента, которая, заметим, относилась к совершенно другой области. Оратор прибегал к анекдотам, сравнениям, ставил вопросы-тезисы, среди которых повторялся вопрос «кто победил в происшедшей революции?», на который он предложил готовый ответ: «победили мы!». Аргументы Павла Николаевича вызвали недоумение у слушавшей его либерально

81 Там же, с. 698. 
настроенной молодежи, но за ним не последовали возражения. На робкие замечания местных противников власти докладчик реагировал ироническими репликами, мимикой, и, наконец, потребовал молчания, чем нарушил правила спора. Он не заботился о том убедил ли он возможных оппонентов, не спорил, а «разъяснял», «вразумлял», «учил реальной политике». В беседе стало доминировать авторитетное слово партийного лидера, излагавшего партийную программу и открывавшего секретные приемы политической борьбы. Его слово не допускало возможности возражений со стороны присутствующих. Он показал себя умелым оратором, пренебрегавшим риторическими правилами убеждения.

В политически противоположном лагере социал-демократов, возглавляемых Лениным, вообще не оказалось места для споров. Слушатели реагировали на речь Ленина аплодисментами, самодовольным смехом, взволнованным шепотом, но не смели с ним полемизировать:

Можно было беседовать в частном порядке и разрешать личные сомнения вопросом: «А как вы думаете, Владимир Ильич, о том-то?» - и слушать, что скажет вождь. Вера в непогрешимость Ильича была так велика, что даже и такое осведомление нужно было облекать в осторожную форму желания познать от пророка и учителя истину 82 .

Очередная ситуация потенциального спора окружения Ленина со своим лидером на тему недавней партийной тактики организации московского восстания показала трусость первых, которые вместо полемических аргументов стали оправдываться, «словно исповедались в грехах». Ленин реагировал на их робкие замечания «хитроватой снисходительной улыбочкой», «нахмуренным челом», раздражением и пренебрежением. Речь Ленина не вызвала возражений и завершилась «громом оваций своему вождю и пророку». Из обвиняемого в ответственности за организацию восстания он превратился в оправданного и по словам повествователя «сам стал напоминать то прокурора, то красноречивого защитника, то вещего пророка...».

Оба выступления, провинциального лидера партии кадетов и лидера Социал-демократической рабочей партии показывают рост значения дог-

82 Там же, с. 689. 
матического слова в публичном дискурсе. Отсутствие полемики свидетельствует о том, что мнения о путях развития России формировалось не в прениях, не в диалоге, а в головах харизматических партийных лидеров.

\section{V.7. Итоги}

Обращение большинства писателей к злободневным общественным темам можно объяснить их гражданской ответственностью за судьбы России. Для изображения горячих общественных тем они охотно использовали спор как жанр позволяющий учесть противоположные точки зрения на окружающую действительность. Можно сказать, что отправной точкой споров о обустройствие России было всеобщее недовольство положением вещей и убежденность в необходимости коренных изменений. Толчком к ним было сознание отсталости России по сравнению с Западом, остро ощущаемое в кризисные ситуации.

Тематика и проблематика споров менялась в соответствии с исторической и политической обстановкой. В начале XIX века споры вызывали реформы Сперанского, масонские представления о прогрессе, чаяния декабристов. В николаевскую эпоху герои спорили о выборе направления развития, прозападного или патриархально русского, о необходимости перестройки сознания личности - субъекта исторических преобразований. С 1860-х годов главными темами стали последствия Великих реформ сверху: новые экономические принципы, положение дворян и крестьян, работа новых учреждений, альтернативные проекты общественного устройства, предложенные социалистами и либералами, корни их идеологий и определение ведущей общественной силы. С 1880-х годов появились новые объекты споров - программы постепеновства и «малых дел», культуртрегерская работа в провинции, толстовство, попытки изменения самодержавного строя на конституционно-парламентской почве, т.е. широко понимаемое внутреннее переустройство России.

В спорах о общественном устройстве России и о направлении ее развития в первой половине века особую активность проявляли западники и словянофилы, во второй - либералы и радикалы. Их представители, несмотря на убежденность в необходимости общественных преобразований, выступая с противоположных политических позиций, заранее исключали компромисс в спорных вопросах и принципиально отклоняли любые 
положителные решения со стороны власти. Споры прерывались в самый неожиданный момент, не завершались заключениями, оставались открытыми. Можно сказать, что политические силы вступали в споры не ради обсуждения важных общественных вопросов во имя общего блага и не для того, чтобы найти наиболее приемлемый выход из ситуации, а с намерением победить противника. Споры о деле превращались в споры о чертах личностей, возглавляющих опредеденную общественную силу, претендовавшую на политическое лидерство. В нашей оценке персональный характер споров был серьезной причиной неуспеха дискуссий о внутреннем устройстве России. Попытки отдельных писателей указать на русскую «партию действия» осуществлялись не в споре, а на событийном уровне. Первенство доставалось не искусным мастерам спора, а личностям сильным не в языке, а в делах, что свидетельствует о недооценке писателями спора как пути к компромиссу. Их скептицизм нашел подтверждение в политической культуре конца века, в которой доминируют голоса политических ораторов, зовущих не к консенсусу, а противоборству и вооруженному восстанию.

С современной точки зрения сложно оценить реальное влияние изображенных на страницах романов споров на общественную жизнь. В художественном дискурсе классиков спор не стал средством решения общественных проблем, а, скорее всего, отражал общественную атмосферу. 


\section{VI. Заключение}

Упоминания о споре на страницах произведений ведущих писателей XIX века показали предрасположенность русского человека к спору, но анализ многочисленных сюжетных ситуаций в художественной литературе привел нас к выводу о беспродуктивности спора как пути к истине и консенсусу.

Участники «русских споров» главным образом были сосредоточены на системе ценностей, на убеждениях и на проблеме обустройства страны.

Спор в литературе начала XIX века вырос из просветительских представлений о необходимости рациональной перестройки общественного строя.

В произведениях романтиков спор изображен формой развлекательного, интеллектуального времяпрепровождения завсегдатаев литературных салонов и участников студенческих кружков. Ценилось высокое искусство слова и красноречия, которые наряду с другими чертами являлись важной составляющей кода дворянской культуры.

В сороковые годы идейные пути участников кружков разошлись в разные стороны и поводов к спорам стало больше. На смену романтической парадигмы с ее прекраснодушием, культом красоты, искусства, дружбы и любви пришла реалистическая парадигма, с преклонением перед наукой и прагматическим отношением к жизни. Литература отреагировала на эти изменения усиленным вниманием к полемическому началу. Контекстом споров литературных героев бывали реальные полемики их творцов со своим окружением, но и с произведениями коллег по перу, метко концептуализирующим окружающую действительность.

С появлением в шестидесятые годы новой общественной формации разночинцев накал споров еще усилился. В кругах радикальной интеллигенции участие в идейно-политическом споре считалось разновидностью 
гражданской активности, заменяющей реальное дело. Выросло значение отрицательного начала и его своеобразного языка, ставшего отличительной чертой разночинской культуры. Пристрастие шестидесятников к полемике вырастало из опыта тайных организаций и журнальной борьбы, которые являлись неотъемлимой частью политической жизни России на протяжении целого века.

Ход исторических событий последней четверти века ослабил надежды на положительные результаты «русских споров» и повлиял на их содержание. Стремление писателей к тому, чтобы в романной форме «захватить все», создать панорамическую картину жизни, отразить многоголосье эпохи, уступило интересу к отдельному человеку. Этому явлению способствовала жанровая трансформация романа в повесть и рассказ. В малых жанровых формах эпический охват действительности заменен фрагментарностью изображения. Предрасположенность русского человека к спорам постепенно превратилась в разочарование этой формой решения проблем и неспособность к диалогу. Последствием стал рост субъективистских настроений и поворот к религии.

В культуре рубежа веков замечается раздел частной и публичной сфер жизни. С появлением политических партий спор на страницах художественных произведений, десятилетиями заменяющий парламентские прения, получил наконец соотвествующее ему место и новое выражение в публичном дискурсе. Опыт этих качественно новых споров отражен в мемуарной прозе.

В контексте рефлексии о месте и роли спора в литературе XIX века принципиальное значение имеет заключение о результатах "русских споров», изображенных на страницах произведений классиков. Итоги исследования их хода и результатов разочаровывают. Сократовское убеждение, что истина рождается в споре, не нашло подтверждения в результатах «русских споров». «Русские споры» в изображении классиков не стали путем к истине, не привели спорщиков к компромиссу, а скорее всего отразили состояние умов, отношение к злободневным вопросам.

Диалектический диалог Сократа и его последователей в лицах Платона и Аристотеля, ориентированный на логические принципы убеждения, не стал для русских спорящих востребованным руководством. Скорее всего победило увлечение собственным красноречием, восходящее к софистической традиции спора. Протагор, изложивший принципы софистического 
спора, признавал значение слова, которое сродни колдовству. В этой традиции риторика считалась словесной игрой. На эту традицию, как кажется, охотно ссылались русские классики, сравнившие спор с шахматной игрой, с изысканным интеллектуальным развлечением. Тем самым они выразили скептицизм в отношении результатов спора.

Игровой характер споров особо заметен в прениях героев Тургенева, интеллектуальный облик которых сформировался в атмосфере философских и литературных кружков. Реплики участников бесед построены не на логической основе, а на противоборстве мнений, свободных ассоциациях и жонглировании словом. Словам и понятиям употребляемым в спорах приписывались разные смыслы, а базовые для сторон понятия осмеивались. В спорах применялись преднамеренные риторические уловки. Самыми частыми являлись подмена предмета спора, перемещение объекта с дела на личность спорщика и следовавшая за этими эристическими уловками аргументация, отличавшаяся умышленными обобщениями, противоречиями, злоупотреблением «общими местами». В освещении теоретиков спора многочисленность риторических уловок является признаком недобросовестного спора, т.е. такого, о котором заранее известно, что не принесет решения спорного вопроса, а послужит единственно удовлетворению тщеславия спорщика. Именно так и обстояло дело в практике «русских споров».

Споры в изображении Гончарова, Толстого, Достоевского и Чехова, вписывались в платоновскую традицию спора. Писатели считали диспуты на философские темы естественной потребностью человека, следствием его интереса к сущности бытия. Хотя они верили, что абсолютная истина существует безотносительно, что она - мера всех вещей, но ее постижение считали невозможным. Эта установка заранее приговорила философский спор на неуспех, придала ему вечный, вневременной характер.

Рефлектирующие герои Толстого, пытаясь определить свое отношение к трансценденции и к другому человеку, выяснить для себя, кем они являются, приходили к выводу, что логический спор является для них непригодным. В толстовском романе истина рождалась не в споре, а в душе человека. Вес аргументов спорящих уменьшался из-за растущего убеждения в бесплодности и игровой натуре спора. Эристические приемы ученых спорщиков становились объектом критики героев занимавших позицию сторонних наблюдателей, но в то же время людей внимательных 
и вдумчивых, которые шли к истине путем противным правилам логики, без посредства суждений и умозаключений.

У Достоевского сознание безуспешности спора на онтологические темы отражено в определениях «проклятые вопросы», «вековечные вопросы». В его произведениях обращает на себя внимание пристрастие «русских мальчиков» к беседам о «вековечных вопросах». Спорщикам присуща убежденность в их неразрешимости, но само желание разрешить «проклятые вопросы» представлено Достоевским отличительной чертой русского характера, одной из тайн «русской души» и вместе с тем ее обреченностью.

Разочарование в споре как в способе постижения истины свойственно и Чехову. Оно отражено в формуле «никто ничего не знает» как своеобразном итоге попыток разрешения философских вопросов. Действующие лица находили руководство к жизни не в итогах спора, а в углубленной, скрытой от других рефлексии или вовсе его не находили и попадали в подавленное состояние. Участие в споре становилось способом бегства от скуки, удовлетворения личного тщеславия. Поведение героев в ситуации спора показывает их неспособность к подлинному общению.

Доминирующее у вышеназванных писателей представление о неразрешимости онтологических вопросов сказалось на скептическом отношении к спору как средству познания истины. Хотя спорщики заранее были убеждены, что участвуют в неразрешимом «вечном» споре, но страдая от этого сознания, они продолжали спорить и далее страдать. В этой черте проявилось психологическое своеобразие «русской души», её своего рода обреченность.

Онтологическим спорам сопутствовали аксиологические споры об обосновании норм поведения личности. Они отличались ярко выраженным полемическим характером в отношении к постулатам сторонников утилитарной этики «разумного эгоизма», нарушавшей традиционные для русской культуры нравственные устои.

В высокохудожественной литературе споры об общезначимых принципах, определяющих направление человеческой деятельности, изображены с использованием ссылок на имена философов - кумиров, соответственно старого и молодого поколений, актуализирующих философские контексты, с использованием литературных цитат и реминисценций и с применением эристических приемов. Их выбор и оценка позволяли опровергнуть чужое слово и утвердить собственную философскую позицию, но и оставить спорный вопрос открытым. 
Создатели идейно ангажированной литературы создали для борьбы с этикой «новых людей» специальный тип полемического романа, поэтика которого была подчинена осуществлению обличительной функции на уровне рамочной структуры произведения и повествовательных стратегий. Изображая споры героев, писатели использовали несобственно-прямую речь, добиваясь эффекта подлинности идейных разногласий. Диалогический характер слова как жанровый признак спора подавлен в них голосом повествователя, надевшего маску писателя - свидетеля и участника романный событий. В этом типе романа преобладала назойливая публицистическая аргументация, отражавшая идейную позицию писателя, отрицательно сказавшаяся на его художественной стороне.

В художественном дискурсе классиков философские споры превращались в бытовые. Полем борьбы за здоровые нравственные устои избиралась семья, что можно объяснить силой семейного начала в русской культуре. Способом той же борьбы становилось изображение альтернативных моделей семейной жизни - свободного союза мужчины и женщины, основанного на биологической основе, и традиционной модели, основанной на христианских началах, имевшее место в полемическом романе. Выбор подобной модели, что особо отметим, был не результатом аргументированного спора, а итогом противопоставления словам последствий поступка. В конечном итоге сила примера превысила силу аргументов. Это позволяет сделать вывод, что спор в полемическом романе, как это ни парадоксально, не имел такого значения, какое можно было ожидать от определения «полемический».

Основное значение в спорах о принципах имело отношение к культурной традиции, особо важное в моменты слома эпох. Точкой соотнесения служили спорщикам принципы опережающей эпохи - просветительской для романтиков, романтической для реалистов, а также такие универсальные для человека ценности, как правда, истина, добро, свобода, долг, порядок. Они были приписаны соответственно поколениям «отцов» И «детей» и порождали споры. Конфликт поколений - явление естественное, но его масштабы, динамика и приписываемая писателями роль, обнаруживают свойственную русской культуре черту «мышления поколениями». Поколению «отцов» свойственен нравоучительный тон в обращении с «детьми», но и заискивание их симпатии и признания. «Детям» свойственны непримиримые позиции в отношении к «отцам», смягчаемые оттенком снисхождения к ним. Отмеченное отсутствие компромисса убеждает в том, 
что поколенческие споры были направлены не на нивелировку разногласий, а на утверждение своей системы ценностей, свойственной культурным кодам - дворянскому и разночинскому.

В художественном дискурсе классиков наряду со спорами о ценностях важное место занимали споры о внутреннем устройстве России. Контекстом этих споров являлась политическая злоба дня, а их интенсивность была исторически обусловлена. Согласно ритму исторических событий можно выделить их несколько стадий.

На первой стадии александровского периода споры отражали обстановку борьбы вокруг реформаторских планов Александра I. На второй, николаевской - гражданскую, но по-разному понимаемую заботу о будущем России и направлении ее развития - прозападном или патриархально русском. На третьем - разногласия вокруг последствий реформ сверху Александра II для отдельных сословий и альтернативных социальных проектов решения общественных проблем. На четвертой - опыт русской действительности 1870-х годов. На очередной - общественные программы постепенных изменений и «малых дел», на последней - политическую злобу дня. Названные стадии имели свою специфику.

Так, например, в начале века споры отражали придворные прения сторонников либеральных реформ и приверженцев метода «железной руки» в управлении страной. Уже на этом этапе обозначилось значение диалога в общественной практике. Искусство убеждения и способность к компромиссу просвещенных реформаторов проигрывали в столкновении с авторитарным стилем правления военных, близким к придворным кругам. Другой причиной разочарования в эффективности спора были недобросовестные практики использования спора как вида мнимой политической активности, своеобразной маски для прикрития гражданского лицемерия. Поведение споривших в ситуации решения важных проблем и следовавшая за этим безуспешность спора, поколебали просветительской верой истинных граждан в эффективность слова и диалога как надежных инструментов общественного договора. Оно нашло отражение в эмоциональной рефлексии Петра Чаадаева, с горечью констатирующего, что соотечественники не усвоили силлогизма Запада.

На второй стадии доминировали споры вокруг выбора пути модернизации России по западноевропейскому образцу или испытанному веками русскому патриархальному укладу. Их контекстом были мнения участво- 
вавших в общественном дискурсе писателей и публицистов. По ходу споров их объект часто менялся, перемещался с дела на личность спорщика. Личностная установка в спорах означала свойственное русской культуре переключение внимания с внешнего на внутреннее. С перемещением акцентов возросло субъективное начало в споре, не способствующее осуществлению первоначально заложенной цели - выбору желаемой модели русской жизни и выделению героя времени. Оно становилось помехой в решении вопросов современного обустройства страны. Споры о чертах личности обнаружили типичный для русского человека разлад ума и воли как причину и препятствие в решении общественных дел, его чрезмерную эмоциональность. Споры решались не силой аргументов, а благодаря весу примеров поведения личности в конкретной ситуации, что отражает поступающее в русской культуре середины века недоверие к слову и утверждение значения деловой основы в общественной практике.

На третьей стадии споров о обустройстве России их накал резко усилился, чему спосособствовали системные реформы сверху. К полемикам провоцировало сознание общественного хаоса и тупика, удачно концептуализированное в толстовской формуле «у нас все это переворотилось и только укладывается». К спорам толкало представление об обмане народа правительством, о нарушении экономических интересов привелигированных сословий, о плачевной ситуации пореформенной России, отраженное в концептуальных метафорах: «гниль», «трясина», «болото», «бездна».

Отрицательные оценки действий правительства исходили от радикалов, защищавших интересы народа, от аристократов и поместных дворян, утративших привилегированную позицию, от новых либералов и предпринимателей, борющихся с общественным неодобрением практических решений экономических проблем и со стороны правительственной администрации. Их общим знаменателем было неудовольствие состоянием страны, но каждая группа отстаивала не общие, а узкосословные интересы.

Радикалы были недовольны социальными условиями и в аргументации ссылались на теории французских социалистов. Они принципиально отклоняли реформаторские действия правительства как половинчатые и предпочитали им силовые способы установления справедливости.

Консервативно настроенные аристократы выступали за отступление от реформ и возвращение к прежней системе. Их несогласие на ограничение сословных привилегий и неуступчивость, глухота на аргументы 
противников обрекали спор на неуспех. При таком отношении какой-либо общественный консенсус становился невозможным.

Либералы выступали за реформы, но их отношение к текущим делам русской жизни и обоснование либеральной практики доктринами английских экономистов, вызывали различные толкования и споры. Их решение было связано с идеологической позицией отдельных писателей. Гончаров приобщал своих героев к либеральным принципам, поручая эту задачу героям-резонерам. В изображении Писемского либералы - это люди сороковых годов, которые в условиях пореформенной России должны были противопоставиться радикалам-социалистам, но из-за присущей им мягкости и стремления оценивать все «смотря по обстоятельствам», оказывались неэффективными. В изображении Тургенева либерализм был видом маски, за которой скрывали свои подлинное лицо консерваторы. В представлении Достоевского и Толстого либералов отличала утилитарная философия заботы о личной материальной пользе, чуждая русскомучеловеку. Разоблачение либералов проходило с применением авторского слова. Забегая вперед, отметим, что только в изображении Чирикова либералы являлись авангардом модернизирующейся России, а их призванием было изменение социально-политического строя и установление конституционной монархии.

Крайность позиций радикалов и либералов в отношении к проблемам русской пореформенной жизни породила новые споры вокруг источников идеологий социализма и либерализма. Их участники, следуя идеологическому стереотипу, единодушно считали, что обе эти идеологии уходят своими корнями в западноевропейскую традицию. С точки зрения предпосылок споров о ведущих общественных силах подобная родня должна была их компрометировать, и можно сказать, что такая цель была достигнута.

Приверженцы вышеназванных идеологий пытались в спорах друг с другом потвердить свое право называться передовой общественной силы, способной наметить направление дальнейшего развития. Критерием оценки являлось участие в «деле». Но «дело» Нежданова и «дело» Соломина - это два разных «дела». Неждановское «дело» - это революционное «дело». Соломинский вариант «дела» - это «малые дела». Этой паре разных по смыслу понятий, ставших русскими идеологемами, отсылающими к разным идеологическим дискурсам, сопутствовало понятие «подвиг», которое в неждановском понимании являлось революционным, а в соломинском - «большим „малым подвигом”» прозаического труда. Беспристрастному выбору 
«дела» мешала принципиальная нерасположенность русского человека к компромиссу, его психологическая черта «все оспорить» и его максимализм, выражавшийся в стремлении добиться всего или вовсе отказаться от участия в прениях. Исторически победила точка зрения, чтобы «дела» решать не в споре, а в борьбе.

Между «большим» и «малым большим» подвигом клином врезалось понятие духовного подвига в варианте вселюбви Достоевского и богослужения Льва Толстого. Энергия преодоления противоположных начал борьбы, злых страстей и обмана путем подвига любви, отсылающая к античному агонуэросу -должна была смягчить, гуманизировать общественный дискурс, но вопреки ожиданиям воспринималась как юродство и сектантство. Выбор совершался не в итоге добросовестного спора, т.е. спора возбужденного добрыми гражданскими побуждениями, а был результатом активного вмешательства авторского слова в виде умозаключения или участия биографического автора в последовавшей за произведением журнальной полемике.

На очередной стадии «русских споров» о обустройстве России идеям радикальных народников была противопоставлена стратегия «постепеновства» и культуртрегерская программа «малых дел» интеллигенции, предложенная либеральными народниками. Споры на столь «прозаические» темы были вялыми по сравнению со спорами шестидесятых годов. Это можно объяснить чертами национального характера. Настроенного на подвиг русского человека отталкивала «проза жизни», наводила на него скуку.

Как было отмечено, к концу века общественный дискурс заметно политизировался. Изменились и жанровые признаки спора. В нем диалогическую установку заменило авторитарное слово лидера, аргументацию - манипуляция. Был нарушен принцип равенства субъектов в споре, что проявилось в беспрекословном подчинении авторитету партийного вождя. Обращает внимание нерешительность спорщиков, которые полагались не на силу аргументов, а подчинялись психологии толпы, т.е. поступали по принципу «я считаю так, как все остальные».

Итак, опыт анализа «русских споров» в художественном дискурсе классиков убедил нас в том, что русские люди были предрасположены к спорам, а спор, получая все новые и новые импульсы, являлся движущей силой общественного дискурса. Однако вопреки заявленному во многих произведениях пристрастию героев к спорам, они не выполняли предполагаемых по дефиниции целей. В большинстве сюжетных ситуаций споров наблюда- 
ется предвзятость предпосылок, переключение внимания из предмета спора на личность оппонента, многократные прекращения прений, подмена одной темы другой, и как следствие, отстутствие выводов. В других ситуациях отсутствие вывода или его неверность являлись эффектом успешной манипуляции и применения эристических уловок в споре, использования в аргументации метафорического языка. Такой спор воспринимался как игра, а не как способ выявления истины, как интеллектуальное развлечение в его высоком варианте и «потеха», «пустая болтовня» в популярном варианте. Это подтверждает родство «русских споров» с софистической традицией.

Спору вербальному сопутствовали невербальные знаки. Свойственные спорщикам эмоции проявлялись в мимике, жестах, нарушении светского этикета и придавали «русским спорам» аффективный характер.

Объектом рефлексии писателей-классиков было само риторическое искусство спорящих. Оно вызывало противоречивые оценки. С одной стороны, красноречие возбуждало признание и даже зависть, с другой стороны, - убеждение в том, что эристика - нерусское искусство. В этом заключении обнаруживалась свойственная русской культуре недооценка логического начала и предпочтение интуитивных путей постижения истины.

Участники «русских споров» не стремились к компромиссу, что можно объяснить чертой русской ментальности и максимализмом русского сознания. Причина неуспеха «русских споров» скрывалась в особенностях мышления русского человека, который в оценке Дмитрия Лихачева был «склонен к крайностям», а по мнению Николая Бердяева, не владел сферой относительного и серединного.

Проникновение различных видов слова - художественного, публицистического и политического, художественный отклик на идейные полемики, продолжение затронутых на страницах художественных произведений проблем в журнальных статьях и участие в полемиках авторов произведений представляют собой вид механизма, принимающего облик спирали и придают русской культуре оттенок агона.

В завершение анализа многочисленных споров, изображенных на страницах произведений русских классиков можно лишь подписаться под словами Лотмана, что в России «нет дара создания средней культуры». Подобное заключение не обещает успеха ни современному, ни будущему общественно-политическому дискурсу. 


\section{ИСПОЛЬЗОВАННАЯ ЛИТЕРАТУРА}

\section{Источники}

Герцен А.И., Собрание сочинений в восьми томах, Издательство «Правда», Москва 1975.

Гоголь Н.В., Собрание сочинений в шести томах, Гос. изд.. Художественная литература, Москва 1949.

Гончаров И.А., Собрание сочинений в восьми томах, Изд. «Художественная литература», Москва 1977.

Грибоедов А.С., Горе от ума, Изд. «Детская литература», Ленинград 1975.

Достоевский Ф.М., Собрание сочинений в десяти томах, Государственное издательство Художественной литературы, Москва 1957.

Лесков Н.С., Полное собрание сочинений, Изд. А.Ф. Маркс, Санкт-Петербург 1897.

Надсон С.Я., Стихотворения, сост. Е.В. Иванова, Изд. «Советская Россия», Москва 1987.

Писемский А.Ф., Собрание сочинений в пяти томах, Изд. «Художественная литература», Москва 1983.

Писемский А.Ф., Взбаламученное море, [Электронный вариант]: az/lib/ru/p/ pisemskij-_a/text_0130/shtml [15 октября 2014].

Пушкин А.С., Собрание сочинений в восьми томах, Изд. «Художественная литература», Москва 1969.

Салтыков-Щедрин М.Е., Избранное, Изд. «Современник», Москва 1976.

Толстой Л.Н., Собрание сочинений в двадиати двух томах, Изд. «Художественная литература», Москва 1980. 
Тургенев И.С., Собрание сочинений в двенадиати томах, Государственное издательство Художественной литературы, Москва 1954.

Чехов А.П., Полное собрание сочинений и писем в тридиати томах. Сочинения, Изд. «Наука», Москва 1985.

Чернышевский Н.Г., Что делать? Из рассказов о новых людях, Изд. «Художественная литература», Ленинград 1969.

Чириков Е.Н., Отчий дом. Семейная хроника, Изд. «Эллис Лак 2000», Москва 2010.

\section{Литература предмета}

Автухович Т.Е., Античная риторика, Изд. Гродненский Гос. у-т, Гродно 2003.

Анненков П.В., Литературные воспоминания, Изд. «Художественная литература», Москва 1983.

Анцупов А.Я., Шипилов А.И., Конфликтология, Изд.ЮНИТИUNITY, Москва 2000.

Аюпов С.М., Аюпов И.С., Романы И.С. Тургенева 1860-х годов в мире контекстов, РКО РУНМЦ МО РБ, Уфа 2010.

Бабаев Э.Г., Роман и время. «Анна Каренина» Л.Н. Толстого, Приокское книжное издательство, Тула 1975.

Бахтин М., Проблемы поэтики Достоевского, Изд. «Художественная литература», Москва 1972.

Бахтин М., Эстетика словесного творчества, Изд. Искусство, Москва 1979.

Бердяев Н., Миросозерияание Достоевского, Ymca-Press, Praha 1923, Paris 1968.

Бердяев Н., Судъба России, ред. Ю.С. Ершова, Изд. МГУ, Москва 1990.

Большой толковый словарь русского языка, ред. С.А. Кузнецов, Изд. Норинт, Санкт-Петербург 2003.

Будагов Р.А., Литературные языки и языковые стили, Изд. «Высшая школа», Москва 1967.

Бурышкин П.А., Масонство в романе Л.Н. Толстого «Война и мир», [в:] Масонство и руская литература, сост. В.И. Новиков, Изд. Искусство, Москва 1998, с. 344-350.

Ветловская В.Е., Поэтика романа «Братья Карамазовы», Изд. «Наука», Ленинград 1977. 
Wierzbiński J., Языковой монументализм в России ХХ века (Диахроническая экспликация научных парадигм), Wydawnictwo UŁ, Łódź 2012.

Володина Н.В., Концепты, универсалии, стереотипы в сфере литературоведения, Изд.ГОУ ВПО «Череповецкий государственный университет», Череповец 2010.

Гройс Б., Политика поэтики, Сб. статей, Изд. ООО «Ад Маргинем Пресс», Москва 2012.

Долинин К.А., Проблема речевых жанров через 45 лет после статьи Бахтина, [в:] Русистика: Лингвистическая парадигма кониза ХХ века, Изд-во С. Петерб. ун-та, Санкт-Петербург 1998, с. 35-46.

Дубин Б., Поколение: социологические границы понятия, [Электронный реcypc] http://polit.ru/article/2002/04/17/474861/б [15 октября 2014].

И.А. Гончаров в русской критике. Сборник статей, ред. М.Я. Полякова, Государственное издательство «Художественная литература», Москва 1958.

Иванов В.В., Кжанровой предыстории прений и споров, [в:] Избранные труды по семиотике и истории культуры, т. III., Москва 2004.

Капри Г., Достоевский-экономист. Очерки по соииологии литературы, перевод из итал., Изд. Фаланстер, Москва 2012.

Катаев В.Б., Проза Чехова: проблемы интерпретации, Изд. МГУ, Москва 1979.

Кашина Н.В., Эстетика Ф.М. Достоевского, Изд. «Высшая школа», Москва 1989.

Куранда Е.Л., Повествовательная структура романа Н.С. Лескова «Некуда» в системе русского антинигилистического романа 1860-1870-х годов, Автореферат диссертации на соискание ученой степени кандидата филологических наук, Псков 2001.

Лакофф Дж., Джонсон М., Метафоры, которыми мы живем, пер. А.Н. Баранова, А.В.Морозова, ред. А.Н. Баранова, Изд. LKI, Москва 2008.

Литература и искусство в системе культуры, ред. В.Б. Пиотровский, Изд. «Наука», Москва 1988.

Лосский Н.О., Достоевский и его христианское миропонимание, Нью-Иорк 1953, с. 254, [Электронный ресурс] www.adinblago.ru.dostoevskiy/4\#5 [15 октября 2014].

Лотман Ю.М., Литературное наследие декабристов, Изд. «Наука», Ленинград 1975. 
Лотман Ю.М., Поэтика бытового поведения в русской культуре XVIII века, [в:] Избранные статьи: в 3 томах, т. І, Изд. Александрия, Таллинн 1990. Лотман Ю.М., Семиосфера, Изд. «Искусство-СПБ», Санкт-Петербург 2001. Манн Ю.В., Тургенев и другие, Издательский центр Российского государственного гуманитарного университета, Москва 2008.

Михайлова М.В., Назарова А.В., Россия как отчий дом, [в:] Чириков Е.Н., Отчий дом, Изд. «Эллис Лак 2000», Москва 2010, с. 3-28.

Могильнер М., Мифология подпольного человека: радикальный микрокосм в России начала ХХ века как предмет семиотического анализа, Изд. Новое литературное обозрение, Москва 1999.

Недзвецкий В., «Захватить все» (менталитет героя русского классического романа ХІХ века), „Slavia Orientalis” 1995, № 3, c. 325-335.

Недзвецкий В.А., Литературные «отиыь» и «дети» в России 60-х годов ХІХ века, «Известия РАН. Серия литературы и языка», 2007, № 5.

Оляшек Б., Русский позитивизм. Идеи в зеркале литературы, Wyd. Uniwersytetu Łódzkiego, Łódź 2005.

Паперно И., Семиотика поведения: Николай Чернышевский - человек эпохи реализма, Изд. «Новое литературное обозрение», Москва 1995.

Поварнин С.И., Спор. О теории и практике спора, третье изд., Изд. «Флинта», Изд. «Наука», Москва 2009.

Поэтика: словарь актуальных терминов и понятий, гл. ред. Н.В.Тамарченко, Изд. Intrada, Москва 2008.

Рошаль А., Писемский и революиионная демократия, Азарбейджанское государственное издательство, Баку 1971.

Скафтымов А.П., Нравственные искания русских писателей, Изд. «Художественная литература», Москва 1972.

Собенников А.С., “Между „есть Бог” или „нет Бога...” (о религиозно-философских традициях в творчестве А.П. Чехова», Изд. Иркутского университета, Иркутск 1997.

Сорокин Ю.С., Антинигилистический роман, [в:] История русского романа, т. II, Изд. Наука, Москва 1969, с. 97-120.

Старыгина Н.Н., Русский полемический роман 1860 - 1870-х годов в ситуаuзи философско-религиозной полемики, Изд. Языки славянской культуры, Москва 2003.

Степанов А.Д., Проблемы коммуникации у Чехова, Изд. Языки славянской культуры, Москва 2005. 
Страхов Н.Н., Из истории литературного нигилизма, 1861-1865, С.-Петербург 1890.

Твардовская В.А., Достоевский в общественной жизни России (1861-81), Изд. «Наука», Москва 1990.

Толковый словарь живого великорусского языка Владимира Даля, Изд. «Русский язык», Москва 1980.

Тюпа В.И., Статус событийности и дискурсивные формации, [в:] Событие и событийность. Сборник статей, ред.В. Маркович, В. Шмид, Изд. Кулагиной - Intrada, Москва 2010, с. 24-36.

Федосюк М.Ю., Нерешенные вопросы теории речевых жанров, «Вопросы языкознания», 1997, № 5.

Фридленденр Г.М., Послесловие, [в:] Ф.М. Достоевский, Собрание сочинений в пятнадияати томах, Ленинград 1989, т. V, с. 523-555.

Чулков Г., Последнее слово Достоевского о Белинском, [в:] Достоевский, Москва 1928, вып. 3, с. 61-81, [Электронный pecypc] http://az.lib.ru/c/ chulkow_g_i/text_0320.shtml [15.ноября 2014]

Шелгунов Н.В., Литературная критика, Изд. «Художественная литература», Ленинград 1974.

Шкаренков И.И., Диалог прозачческий, [в:] Поэтика: словарь актуальных терминов и понятий, гл. ред. Н.В. Тамарченко, Изд. Кулагиной - Intrada, Москва 2008, с. 57-58.

Щукин В., Русское западничество сороковых годов ХІХ века какобщественно-литературное явление, Wyd. UJ, Kraków 1987.

Щукин В., Русское западничество. Генезис - сущность, историческая роль, Ibidem, Łódź 2001.

Щелковникова Л.Ф., Социально-философбкие воззрения Н.С. Лескова, Автореферат диссертации на соискание ученой степени кандидата филологических наук, Москва 2000.

Яровой А.В., Агон и агональная культура, [Электронный ресурс] http:// dikoepole.com/2010/03/10/agon_kultura [15 октября 2014]

\section{Литература на польском языке}

Balcerzan E., Metafora a interpretacja, [w:] Studia o metaforze II, Wyd. Zakład Narodowy im.Ossolińskich, Wrocław-Warszawa-Kraków 1983. 
Borkowska G., Dialog jako kategoria poetyki, [w:] Problemy teorii literatury, Seria 4, Wyd. Zakład Narodowy im.Ossolińskich, Wrocław-Warszawa-Kraków, 1998, s. 205-245.

Czerwińska J., Agon literacki Eurypidesa na tle agonistycznego charakteru kultury greckiej, [w:] „Sprawozdania z czynności i posiedzeń naukowych ŁTN”, t. LVI, 2002, s. 113-138.

Duszak F., Tekst, dyskurs, komunikacja międzykulturowa, Warszawa 1998.

Duszak F., Pawlak N., Anatomia gniewu. Emocje negatywne w językach i kulturach świata, Wyd. Uniwersytetu Warszawskiego, Warszawa 2003, s. 125-137.

Jakel O., Metafory w abstrakcyjnych domenach dyskursu. Kognitywno-lingwistyczna analiza metaforycznych modeli aktywności umysłowej, gospodarki i nauki, przekł. M. Banaś, Br. Drąg, Kraków 2003.

Kamińska A., Kategoria pokolenia we współczesnych badaniach nad społeczeństwem i kultura - przeglą problematyki, „Kultura i Historia” 2007, № 11.

Kita M., Wywiad prasowy. Język - gatunek - interakcja, Wyd. Uniwersytetu Śląskiego, Katowice 1998.

Kochan M., Pojedynek na słowa. Techniki erystyczne w publicznych sporach, Wyd. Znak, Kraków 2005.

Ossowska M., Koncepcje pokolenia, „Studia Socjologiczne” 1963, № 2, c. 47-51.

Przebinda G., Od Czaadajewa do Bierdiajewa. Spór o Boga i człowieka w myśli rosyjskiej (1832-1922), Nakładem PAU, Kraków 1998.

Schopenhauer A., Erystyka czyli Sztuka prowadzenia sporów, przekł. B. i Ł. Konorscy, Wyd. 2, Kraków, Wyd. Literackie, 1976.

Walicki A., Osobowość a historia. Studia z dziejów litertury i myśli rosyjskiej, PWN, Warszawa 1959.

Walicki A., Osobowość a historia. Studia z dziejów litertury i myśli rosyjskiej, PWN, Warszawa 1959.

Walicki A., Filozofia prawa rosyjskiego liberalizmu, Instytut Studiów Politycznych PAN, Warszawa 1995.

Walicki A., Rosja, katolicyzm i sprawa polska, Wyd. Prószyński i S-ka, Warszawa 2002.

Wyka K., Rozwój problemu pokolenia, [w:] Modernizm polski, Wydawnictwo Literackie, Kraków 1968. 


\section{PE3ЮME}

\section{„Spory rosyjskie” w dyskursie artystycznym klasyków}

\section{Streszczenie}

Dialog w komunikacji międzyludzkiej i społecznej stanowi niepodważalną wartość, jednak często przeradza się w spór lub kłótnię. W utworach klasyków rosyjskich znajdujemy wiele wypowiedzi bohaterów literackich, świadczących o skłonności Rosjan do prowadzenia sporów. Treść toczonych przez nich sporów dotyczyła tematów błahych, ale również, a nawet przede wszystkim, spraw dla Rosjanina najważniejszych - istnienia Boga oraz systemu wartości, którymi winien kierować się człowiek, a także różnych problemów obejmujących niemal cały obszar życia społecznego.Tematy te były przedmiotem sporów na spotkaniach towarzyskich, posiedzeniach uczestników kółek filozoficznych i tajnych stowarzyszeń, wreszcie podczas rozmów zwykłych ludzi, traktujących spór jako rozrywkę intelektualną. Można więc nazwać je „sporami rosyjskimi”. Znalazły one odzwierciedlenie w dyskursie artystycznym klasyków.

Różnorodność tematów i środowisk uczestniczących w sporach, ich zaangażowanie intelektualne i emocjonalne, pozwala na wysunięcie tezy, że spór był integralną częścią kultury rosyjskiej. Spór w dyskursie artystycznym jest przez nas traktowany w Bachtinowskim rozumieniu terminu jako prymarny gatunek mowy, stosowany we wtórnych gatunkach wyższego rzędu oraz jako rodzaj zdarzenia komunikacyjnego w łańcuchu zdarzeń fabularnych. Spór jako forma komunikacji zakłada stosowanie przez strony określonych technik argumentacyjnych, mających na celu dotarcie do prawdy, bądź zwycięstwo lub wprowadzenie w błąd przeciwnika, nawiązujące do tradycji dialogu sokratejskiego i dialogu 
sofistycznego. Poznanie uczestników i ich intencji, prześledzenie przebiegu i rezultatów sporów w utworach klasyków ma znaczenie dla określenia perspektywiczności sporu we współczesnej kulturze i rzeczywistości politycznej.

Przedmiotem badania są spory w utworach klasyków, przede wszystkim w powieściach, ale również w komedii A. Gribojedowa Mądremu biada, uświadamiającej znaczenie prawa jednostki do posiadania własnych i głoszenia niezgodnych z opinią ogółu poglądów oraz w opowiadaniach A. Czechowa, a także kronice rodzinnej Dom ojczysty J. Czirikowa, naświetlającej sytuację polityczną na przełomie wieków. Przedmiotem analiz szczegółowych są spory o wartości i spory na temat szeroko rozumianych przemian ustroju wewnętrznego Rosji w wieku dziewiętnastym, ich uczestnicy, przebieg, chwyty erystyczne, rezultaty.

Cechą „sporów rosyjskich” był ich charakter pokoleniowy, co oznacza, że uczestnicy występowali nie w imieniu własnym, lecz pokolenia, rozumianego w sensie kulturowym. Międzypokoleniowy konflikt „ojców i dzieci” odzwierciedla starcie dwu formacji kulturowych, szlacheckiej i tzw. raznoczyńskiej, utożsamianych odpowiednio z pokoleniem lat czterdziestych i lat sześćdziesiątych. Ich system wartości stanowił punkt odniesienia identyfikacji pokoleniowej dla późniejszych generacji. Można więc stwierdzić, że uczestnicy ówczesnych sporów „myśleli w kategoriach pokolenia”.

Spory o wartości dotyczyły zarówno tematów uniwersalnych, takich jak istnienie Boga, istota człowieka, człowiek a transcendencja, dobro i zło, prawda, przyjaźń i miłość, wolność i odpowiedzialność oraz tematów konkretnych, jak małżeństwo i rodzina, szacunek wobec starszych, zobowiązania moralne jednostki, problem winy i kary. Uczestnicy sprzeczali się o potrzebę istnienia zasad jako takich oraz o filozoficzne podstawy etyki. Spory na wymienione tematy były często podporządkowane założeniom ideowym pisarzy. Stąd wynikła potrzeba uwzględnienia w badaniach sporu odmian powieściowych: homofonicznej, polifonicznej i polemicznej oraz specyfiki innych gatunków, na przykład opowiadania czy kroniki, w których stanowisko autora wobec świata przedstawionego jest wkomponowane w poetykę gatunku.

Specyfikę „sporów rosyjskich” o wartości stanowiło ich ideologiczne uwikłanie. Obiektem szczególnego zainteresowania stron sporów były zasady głoszone przez socjalistów i liberałów, nierosyjskie korzenie ich ideologii, którym przeciwstawiono rosyjskie wartości patriarchalno-konserwatywne. Spory przebiegały w atmosferze napięcia, której towarzyszyły silne emocje. Decydujące znaczenie 
dla ich rezultatów miała nie argumentacja logiczna, lecz siła pozytywnego przykładu, co świadczy o niedocenieniu przez pisarzy rosyjskich roli rozumowania i postępującym zachwianiu zaufania do słowa. Erystyka jako sztuka prowadzenia sporów była oceniana jako obca człowiekowi rosyjskiemu sztuka manipulacji, w której celowali ludzie ukształtowani w kulturze Zachodu.

Spory na temat przemian wewnętrznych w Rosji były dyktowane przez rytm wydarzeń i stanowiły swoisty komentarz do szeroko rozumianej historii politycznej. Pisarze podejmowali gorące tematy społeczne, kierując się troską o dobro i wielkość Rosji. Źródłem sporów były odmienne zapatrywania na temat kierunku rozwoju kraju, wizji postępu i jego twórców, postaw jednostek w życiu społecznym, stosunek do reform odgórnych i projektów alternatywnych oraz poglądy na temat wiodącej siły społecznej, a pod koniec wieku programów partii politycznych.

Szczegółowe analizy przebiegu i rezultatów sporów upoważniają do wniosku, że niezależnie od deklarowanego upodobania Rosjan do sporu, miał on stosunkowo niewielkie znaczenie społeczne i kulturowe. Złożyło się na to kilka przyczyn:

- swoisty konserwatyzm w postrzeganiu wartości narodowych i chrześcijańskich jako nienaruszalnych, obrona tradycyjnych kolektywnych zasad współżycia społecznego z jednej strony i radykalizm burzycieli utrwalonego tradycją porządku z drugiej strony,

- programowe odrzucanie kompromisu i postrzeganie uczestnictwa w sporze jako walki prowadzącej do zwycięstwa,

- stosowanie chwytów erystycznych, świadczących o świadomym traktowaniu sporu nie jako drogi dochodzenia do prawdy, lecz wprowadzenia w błąd przeciwnika z zamiarem jego pokonania,

- dominacja intencji osobistych uczestników nad interesem ogólnym, uzależnienie argumentacji od gustów i przekonań słuchaczy,

- psychiczna podatność uczestników na manipulacje słowne ze strony żądnych dominacji liderów,

- cechy mentalne uczestników, jak maksymalizm i emocjonalne zaangażowanie wraz z konsekwencjami w postaci nieuzasadnionego wycofania się z dyskusji, nieoczekiwanego zawieszania bądź przerywania sporu, odrzucenia kompromisu i preferowania rozwiązań siłowych, co można tłumaczyć romantycznym charakterem Rosjan, ich marzeniem o uczestnictwie w wielkiej sprawie i lekceważeniem spraw przyziemnych. 
„Spory rosyjskie” wyraźnie ciążyły ku tradycji sofistycznej. W tę tradycję wpisywały się w szczególności spory na tematy społeczne. Ich charakter zaważył na upolitycznieniu gatunku, jego przekształceniu w przemówienie polityczne.

Niektórzy pisarze, jak Tołstoj czy Leskow, świadomi niedoskonałości sporu $\mathrm{w}$ dyskursie publicznym, odwoływali się w dowodzeniu racji nie do sztuki argumentacji, lecz siły przykładów. W ich przedstawieniu o wyborze i słuszności prezentowanego stanowiska decydowały nie werbalne polemiki, ale postępowanie jednostki. Inni, jak Dostojewski czy Czechow, traktowali spór jako z założenia nierozstrzygalny.

Spory w dyskursie artystycznym klasyków świadczą o niedocenieniu w kulturze rosyjskiej potencjału dialogowego, co źle prognozuje na teraźniejszość i przyszłość polityczną. 


\section{'Russian disputes' within an artistic discourse by the classics}

\section{Summary}

A dialogue can be seen as a well established value in interpersonal and social communication, however it is often likely to turn into a heated dispute or quarrel. In the works of some Russian classics there are hosts of critical statements and lines of thought made by protagonists, which seem to indicate the Russian's inclination to engage in disputes on controversial issues. Some of the disputes that are carried out by different fictional characters may seem be too trivial in content, but in the majority of cases they concern matters of the utmost importance to the Russian people: the existence of God or a set of values to follow, but also diverse issues that encompass most areas of social life and human relations. These themes have been the object of controversies and stormy debates among the disputants in social meetings, philosophy groups and clandestine societies, and finally, in conversations of ordinary people who view the dispute as a contest or just intellectual pastime. They can be called 'Russian disputes', and as such they have found their reflection in the literary works discussed.

A great diversity of themes and milieus that participate in such disputes, often with a high degree of emotional involvement, can be a proof that a dispute has been an integral part of Russian culture. Clashes of opposed opinion and ideas in a literary and artistic dispute have been treated here in Bakhtin's sense of the term as a primary speech genre that is used in the secondary genres of higher degree and as a particular kind of communicative event in the narrative train of fictional events. A dispute as a form of communication presumes the use of specific argumentative techniques to reach the truth or victory, or simply to mislead the opponent by following the tradition of the Socratic-Sophist dialogue. Getting to know the 
disputants and their intentions, as well as a careful examination of the course of the debate in the works of classic authors plays an important role in defining the 'prospectiveness' of dispute in contemporary culture and political reality.

The subject matter of our research has been disputes in the works of classic authors, predominantly in novels, but also in A.Griboyedov's comedy Woe from Wit that has played a part in raising awareness of individual's right to having and propagating their own views that are different from the officially stated position, as well as in short stories by Anton Chekhov, and Yevgeny Chirikov's family chronicle Otchij dom that provides an in-depth insight into the political situation at the turn of the century. The subject of detailed analysis has been disputes over values and disputes on broadly understood systemic transformation within 19th century Russia, participating parties, the course of events, eristic stratagems and the results.

A common feature of 'Russian disputes' has been their generational character, which means that the disputants would act not in their own names but in the name of generation to be meant in cultural sense. The intergenerational conflict situation between 'fathers and sons' has been reflected in the clash of two cultural formations: among the members of the nobility and representation of different 'estates' identified respectively with the generation of the 40 s and that of the 60 s. Their set of values has been a point of reference for the generational identification and for the later generations. And, thus it can be said that those participating in disputes of the time 'thought in terms of generation'.

Disputes over values were often concerned both with universal themes such as the existence of God, the essence of man, man and transcendence, good and evil, truth, love and friendship, freedom and responsibility, and with specific topics like marriage and family, respect for the elders, moral obligations, the moral obligations of individuals, the issue of crime and punishment. The disputants would argue for the existence of principles and values as such, and for the 'philosophical foundations' of ethics. Disputes on the above themes were often subordinated to the ideological assumptions of authors. Hence, the need for taking into account different features of narrative: homophony, polyphony and polemic as well as some other literary genres, such as a short story or chronicle where the author's position towards the depicted world is incorporated into the poetics of the genre.

The specific quality of "Russian disputes" on values was their ideological entanglement. The object of particular interest to the disputing sides was the 
rules proclaimed by socialists and liberals, the non-Russian roots of their ideology that were contrasted with conservative and patriarchal attitudes. Disputes would be proceeded in tense atmosphere accompanied by strong emotions. Decisive for their results was not a logical argument but the power of positive example, which signifies underestimation of the role of logical reasoning and gradual undermining of confidence in the word. Eristic as the art or practice of debate and argument was often regarded as the art of mental trickery and manipulation, rather alien to the Russian mentality, the art in which only those who have been shaped in Western culture would excel.

Disputes on the internal transformations in Russia were dictated by their rhythm and constituted a peculiar commentary on broadly understood political history. Guided by the concern for the good and greatness of Russia, the writers chose to take up topical themes.The major source of controversies seemed to be different opinions on the line of development of the country, vision of progress and of its authors, individual's behaviour and attitudes in social life, attitude towards top-down reforms and alternative projects as well as opinion on the leading force of the society, and towards the end of the century - the programmes of political parties.

Although detailed analyses of proceedings and outcomes of disputes point to the conclusion that irrespective of the Russians' penchant for disputing, it seems that it was of relatively little social and cultural significance. The following have contributed to this:

- a peculiar conservative way of perceiving Christian and national values as inviolable, defence of collective traditional principles of social coexistence on the one hand and traditionally-established order on the other hand;

- arguing for the sake of conflict, rejecting compromise on principle, and regarding participation in disputes as a fight aimed at victory;

- using dishonest stratagems, which implies the conscious treatment of dispute not as a way of reaching the truth but as that of defeating the other side;

- dominance of disputants' personal intentions over general interest, and dependence of disputants' arguments on their convictions and preferences;

- psychological susceptibility to linguistic manipulation by dominant leaders;

- mental qualities and characteristics of disputants such as maximalist attitude and emotional involvement together with consequences in the 
form of unjustified withdrawal from debate or its unfounded suspension or interruption, or rejection of compromise and preference for resolution by force, which may account for the romantic spirit of the Russians and their dreams in participating in the cause and ignoring mundane matters.

'Russian disputes' have clearly leaned towards the Sophist tradition. Disputes on social themes in particular would have been depicted in this context. Their character has determined politization of the genre turning it into a political speech. However, some writers, including Tolstoy and Leskov while being well aware of inadequacy of public polemic in proving their right would resolve into the force of example rather than into the art of argumentation. In their depiction the choice and rightness of the position depended not on verbal polemics but on the conduct of an individual. Other writers, such as Dostoyevsky and Chekhov tended to view the dispute as insoluble in principle.

A literary and artistic dispute among classic authors reflects the underrating of potentiality of dialogue in Russian culture, which does not bode well for the present and the future time. 


\section{ЛИТЕРАТУРОВЕДЕНИЕ}

\section{ИДЕИ В ХУДОЖЕСТВЕННОЙ ЛИТЕРАТУРЕ}

В предлагаемой читателю книге Б. Оляшек расматриваются «русские споры» в художественном дискурсе классиков XIX века. Толчком к исследованию темы послужили многочисленные высказывания литературных героев о предрасположенности русского человека к спорам.

Несмотря на это утверждение, автор выдвигает тезис о несостоятельности «русских споров» в освещении классиков, поддерживая его анализом многочисленных сюжетных ситуаций дискуссий о важнейших для русского сознания жизненных ценностях, и об обустройстве России в XIX веке, изображенных на страницах их произведений. Особое внимание уделяется содержанию споров, их участникам, ходу прений, эристическим приемам и результатам «русских споров».

Автора, в частности, интересуют такие аспекты проблемы как достижение спорящими истины, возможность консенсуса в общественных вопросах, отсылающие к традициям сократовского и софистического споров, а также причины несостоятельности «русских споров».

Книга адресована как специалистам, так и всем интересующимся русской литературой, культурой и ментальностью.

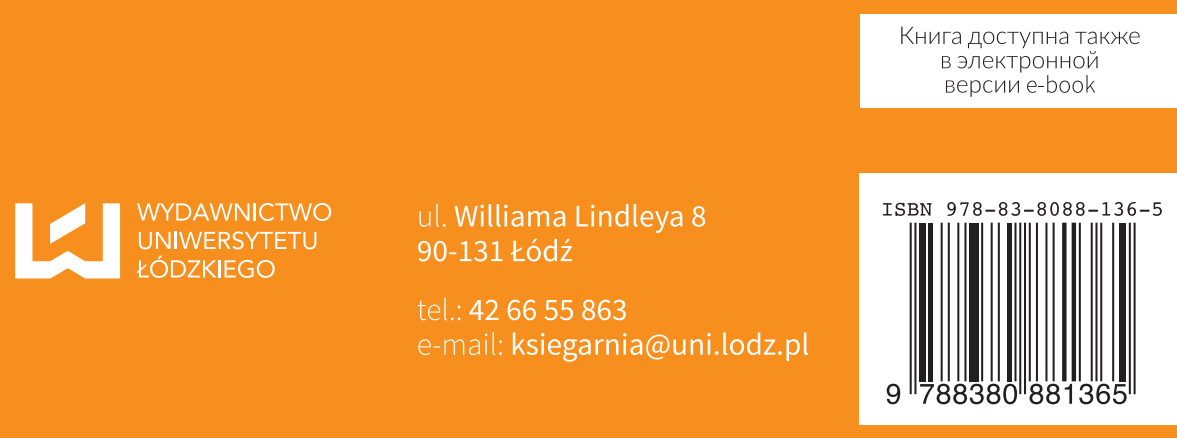

